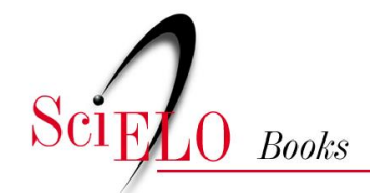

\title{
O Estado, a agricultura e a pequena produção
}

\author{
John Wilkinson
}

WILKINSON, J. O estado, a agricultura e a pequena produção [online]. Rio de Janeiro: Centro Edelstein de Pesquisas Sociais, 2008, 229 p. ISBN: 978-85-9966-271-7. Available from SciELO Books $<\underline{\text { http://books.scielo.org }>\text {. }}$

\section{cc) $\$(0)$}

All the contents of this chapter, except where otherwise noted, is licensed under a Creative Commons Attribution-Non Commercial-ShareAlike 3.0 Unported.

Todo o conteúdo deste capítulo, exceto quando houver ressalva, é publicado sob a licença Creative Commons Atribuição Uso Não Comercial - Partilha nos Mesmos Termos 3.0 Não adaptada.

Todo el contenido de este capítulo, excepto donde se indique lo contrario, está bajo licencia de la licencia Creative Commons Reconocimento-NoComercial-CompartirIgual 3.0 Unported. 


\section{BIBLIOTECA VIRTUAL DE CIÊNCIAS HUMANAS}

\section{O ESTADO, A AGRICULTURA E A PEQUENA PRODUÇÃO}

\section{John Wilkinson}

centro edelstein de pesquisas sociais 
John Wilkinson

\section{O Estado, a agricultura e a pequena produção}

\section{Rio de Janeiro}

2008

Tentro edelstein de pesquisas sociais
Esta publicação é parte da Biblioteca Virtual de Ciências Humanas do Centro Edelstein de Pesquisas Sociais - www.bvce.org

Copyright (C) 2008, John Wilkinson

Copyright (c) 2008 desta edição on-line: Centro Edelstein de Pesquisas Sociais

Ano da última edição: 1986

Nenhuma parte desta publicação pode ser reproduzida ou transmitida por qualquer meio de comunicação para uso comercial sem a permissão escrita dos proprietários dos direitos autorais. A publicação ou partes dela podem ser reproduzidas para propósito não-comercial na medida em que a origem da publicação, assim como seus autores, seja reconhecida.

ISBN 978-85-99662-71-7

Centro Edelstein de Pesquisas Sociais

www.centroedelstein.org.br

Rua Visconde de Pirajá, 330/1205

Ipanema - Rio de Janeiro - R]

CEP: 22410-000. Brasil

Contato: bvce@centroedelstein.org.br 


\section{Sumário}

Agradecimentos

Introdução

\section{Primeira parte}

Capítulo um - O conceito de "pequeno produtor"

1. A política governamental e o minifúndio antes do POLONORDESTE ........................................................... 11

2. O contexto da estratégia do POLONORDESTE .......................... 13

3. O conceito de "pequeno produtor" para o

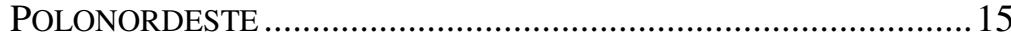

4. O conceito de "pequeno produtor" como um consenso do

sistema de planejamento estatal.............................................. 16

5. Convergência com os debates acadêmicos da década de

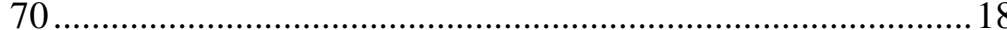

6. A estratégia de modernização do pequeno produtor ...............21

7. A estratégia de desenvolvimento rural do Banco Mundial

e o POLONORDESTE .................................................................. 22

8. A agroindústria e os novos termos do debate acadêmico .......25

9. Conclusão ..................................................................... 30

Capítulo dois - A exploração familiar e o trabalho assalariado.

Limites do debate clássico............................................................ 31

1. A influência atual do debate clássico ....................................31

2. Chayanov e a lógica não-capitalista da exploração camponesa

4. Lênin, o camponês médio e o trabalho assalariado .................4

5. A teoria de Chayanov e a questão do trabalho assalariado.....47

6. Chayanov, a agroindústria e a lógica não-capitalista do

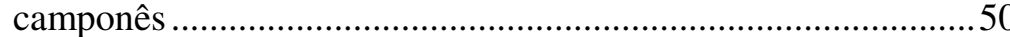

7. Lênin: o camponês médio revisitado .....................................52

8. A exploração familiar e a agroindústria nos debates da

Segunda Internacional .......................................................5

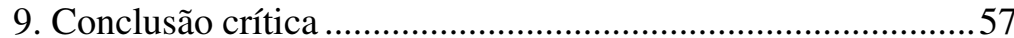

Capítulo três - O pequeno produtor no Nordeste brasileiro ...........59

1. Características específicas do pequeno produtor brasileiro

e o debate feudalismo $\mathrm{x}$ capitalismo.
2. "Farmerização" e fim do latifúndio

3. O minifúndio - reserva de força de trabalho ou setor produtivo?

4. Análise dos sistemas de produção e o setor minifundiário.....71

5. A unidade familiar e o trabalho temporário..........................8 80

6. Conclusão

\section{Segunda parte}

Introdução

Capítulo quatro - PDRI Paraguaçu: a modernização do

pequeno produtor à sombra do latifúndio ......................................90

1. Caracterização da região.......................................................99

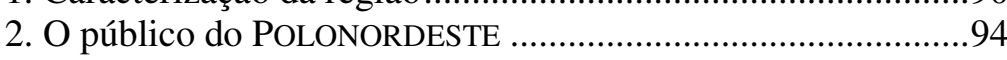

3. O POLONORDESTE e as principais tendências na região .........96

4. Análise critica das pesquisas de campo existentes ...............108

5. Conclusão ............................................................................. 127

Capítulo Cinco - Serra do Ramalho. Modernização e

colonização por pequenos produtores .........................................129

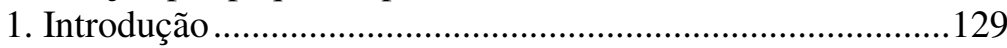

2. Características específicas do projeto ..................................131

3. Análise dos dados globais.............................................132

4. Interpretação dos dados recolhidos no estudo de campo ......143

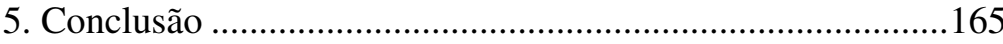

Capítulo seis - Irecê: um caso avançado de modernização ..........167

1. Padrões de ocupação e características enquanto zona

produtora de alimentos .......................................................167

2. Dados globais sobre a evolução do POLONORDESTE .............175

3. Resultados da pesquisa sobre o setor minifundiário de

Irecê ................................................................................. 177

4. Evidências obtidas na pesquisa de campo da EMATERBA ....181

5. Crédito de investimento e o público do POLONORDESTE .....184

6. Caracterização do pequeno agricultor modernizado..............186

7. Mercantilização x associativismo ........................................188

8. Modernização, mecanização e tecnologia alternativa............191

9. Contradições básicas do processo de modernização..............195

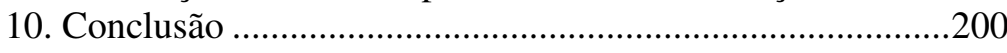

Conclusão ...........................................................................203

1. Síntese dos argumentos....................................................203 
2. A modernização e os novos termos do debate 208

3. A tese da "modernização-capitalismo". 209

4. A tese da articulação em novo estilo e suas limitações ........210

5. A tese do complexo agroindustrial ................................... 213

6. Subordinação real e conclusões extraídas dos trabalhos de campo 216 7. Crítica dos conceitos de subordinação real e de complexo agroindustrial

Bibliografia

\section{Agradecimentos}

A elaboração deste trabalho dependeu de muitos e variados estímulos. Em primeiro lugar devo agradecer ao meu tutor da Universidade de Liverpool, Inglaterra - Colin Henfrey - que conseguiu tirar-me de preocupações outras, e encher-me de fascínio pela Língua Portuguesa, pela Bahia, e o camponês; tudo isto desconhecido para mim até então, e cujos comentários cuidadosos contribuíram em muito para a definição final deste trabalho.

No Brasil meu acesso ao pequeno produtor e a problemática de extensão rural e modernização foi facilitado de maneira decisiva pelo apoio que recebi de João Saturnino da Silva, no período coordenador da EMATER - na Bahia. Mais tarde, quando do meu retorno ao Brasil, foi ainda ele, então coordenador técnico da CEPA-Ba, que criou as condições para completar este trabalho.

Agradeço, também, aos colegas da CEPA-Ba, a fonte de muitas discussões proveitosas, e especialmente a Job Brasileiro e Cristina Maria Macedo de Alencar com quem a pesquisa sobre o projeto de Colonização do INCRA foi elaborada, sem esquecer também os assistentes que contribuíram decisivamente para a execução desta pesquisa.

Às unidades técnicas dos PDRI de Paraguaçu e Irecê, e às agências locais da EMATER-Ba, nestas áreas, pela sua disposição em discutir todos os aspectos da problemática do pequeno produtor - uma disposição decorrente de seu compromisso evidente com a transformação de suas condições de vida.

Também de grande valor para o desenvolvimento dos temas básicos deste trabalho foram as discussões surgidas de palestras dadas no Latin American Centre em Liverpool, no Centro de Pós-Graduação em Desenvolvimento Agrícola (UFRRJ), e na Associação Nacional para PósGraduados nas Ciências Sociais (Nova Friburgo, 1980).

Uma influência decisiva para o aprofundamento de minhas idéias sobre a questão geral de capitalismo e agricultura tem sido as discussões e trabalho em conjunto com David Goodman e Bernardo Sorj. 
Financeiramente este trabalho não teria sido concluído sem o apoio do Social Science Research Council na Inglaterra e da Fundação Ford, que me deram a oportunidade de enfrentar a teoria com seu objeto concreto.

Para a publicação deste trabalho quero agradecer, em primeiro lugar, ao meu amigo e colega de trabalho, João Carlos Duarte; aos colegas da CEPA-Ba e especialmente ao seu diretor-presidente, Moacyr Dunham de Moura Costa; e à equipe da "Hucitec" por sua capacidade e paciência em superar obstáculos.

$\mathrm{E}$, finalmente, a Bete e Isadora que durante esta pesquisa se tomaram sujeitos de um projeto paralelo, cuja descoberta de suas personalidades irredutíveis foi também a base para o reconhecimento da singularidade dos "sujeitos" deste trabalho.

\section{Introdução}

O debate sobre a questão agrária no Brasil durante a década de 70 pode ser visto, retrospectivamente, como uma tentativa de enfrentar a superação política e econômica, pós-golpe militar, do debate clássico "feudalismo x capitalismo" dos anos 50 e 60.

Politicamente, o golpe de 64 fechou as portas para a reforma agrária; economicamente, o "milagre brasileiro" pós-68 redefiniu a natureza do mercado interno, tomando redundante a própria reivindicação pela reforma agrária em sua conotação tradicional, ${ }^{1}$ independentemente da conjuntura política.

Os principais autores que estabeleceram os termos desse debate, ${ }^{2}$ em nome de um ataque ao esquema dualista da tese "feudal" e à sua imagem conservadora refletida na versão cepalina, ${ }^{3}$ substituíram este esquema por uma versão harmoniosa do mesmo dualismo.

O "atraso" "4 do setor agrário antes considerado um freio ao crescimento industrial por induzir ao subconsumo, passou a ser encarado como precondição estrutural para a acumulação na indústria, aumentando a taxa de lucro pela redução nos custos do capital variável. Tratar-se-ia de uma variante, particular às economias não-coloniais e não-imperialistas, da "acumulação primitiva", substituindo a clássica expropriação dos meios de produção do campesinato pela expropriação de sua produção. ${ }^{5}$

Uma tal articulação, quer teorizada como um mecanismo de 
acumulação "estrutural e não apenas genética"6 nas condições do capitalismo dependente, ${ }^{7}$ quer teorizada como uma "transição cristalizada" específica do capitalismo autoritário, ${ }^{8}$ compartilha com a concepção tradicional uma visão dualista do próprio setor agrário. ${ }^{9}$

A manutenção da agricultura camponesa de subsistência, além de alimentar a acumulação industrial, teria servido de forma idêntica ao setor agropecuário exportador, pela redução dos custos do trabalho rural. Este setor exportador, por fornecer as divisas para a importação de bens de capital, foi visto como o objeto exclusivo dos estímulos modernizadores da parte da política estatal.

De acordo com esta posição, o setor de subsistência permaneceu imune a estas medidas modernizadoras; além disso, devido a sua subordinação ao capital comercial, foi impedido de sofrer os efeitos de possíveis incentivos provenientes do mercado. Por outro lado, a questão do mercado interno tinha sido resolvida pela redefinição do setor de bens de consumo, a qual, por sua vez, gerou uma correspondente concentração do

\footnotetext{
${ }^{6}$ Ver Oliveira, $O p$. cit. Entretanto, em seu último trabalho sobre a intervenção estatal no Nordeste e a criação da SUDENE, o autor vê esta última como fator de homogeneização das condições socioeconômicas para a instalação do capitalismo na região. Embora não sejam extraídas as implicações desta posição, ela ao que parece indicaria o fim de uma articulação estrutural com o "arcaico" setor rural. Ver Elegia para uma re(li)gião, Paz \& Terra, 1971.

${ }^{7}$ Usamos este termo aqui num sentido livremente descritivo, embora estejamos a par e compartilhemos de muitas das críticas que seu uso como conceito explanatório tem provocado. Para uma contribuição recente e penetrante, ver Henfrey, C. Dependency, Modes of Production, and the Class Analysis of Latin America, Latin American Perspectives, VIII $(3 / 4)$.

${ }^{8}$ Ver Velho, O. G. Capitalismo autoritário e campesinato, São Paulo, 1976.

${ }^{9}$ Isto não deve ser confundido com o dualismo neoclássico, melhor definido no conceito de autocontrole empregado por R. M. Paiva, o principal defensor desta ideia (ver o Setor agrícola do Brasil, São Paulo, 1976). Aqui a inelasticidade da demanda é vista como um limite ao grau de modernização do setor de produção de alimentos, pois a modernização leva rapidamente a uma queda dos preços como resultado de incrementos na produção, com o que se restaura a competividade camponesa, uma vez que esta produz independentemente de margem de lucro. O novo contexto criado pela agroindústria também serve para solapar qualquer tendência semelhante pela progressiva redução tanto de produtos alimentares quanto não-alimentares à condição de matérias-primas suscetíveis de reorientações sucessivas em termos de produto final, com o que supera a inelasticidade clássica da demanda do mercado.
}

poder de compras estimulada pelas políticas creditícias estatais, tornando desta forma a questão da realização independente do mercado rural. ${ }^{10}$

Tal inversão da tese dualista, construída sobre as antinomias tradicionais cidade $\mathrm{X}$ campo, produtos (nobres) de exportação x produtos (básicos) para mercado interno, foi, contudo, sendo superada na prática por uma reestruturação das relações entre agricultura e indústria, que tomou redundante qualquer análise que encarasse o setor agrário como isolado da acumulação industrial.

Empiricamente, a mudança de prioridades que privilegiou a produção agrícola intensiva em lugar da extensiva pode ser atribuída ao fechamento da fronteira, que bloqueou a expansão orgânica da produção de subsistência. Contudo, este fechamento da fronteira agrícola foi ele próprio o produto de uma mudança na política, refletindo a predominância de frações de capital voltadas para novas formas de acumulação na agricultura. Na prática, o que houve não foi um esgotamento natural da fronteira, mas sim sua ocupação massiva, primeiramente na Amazônia, e mais recentemente no Cerrado, por capitais agroindustriais multinacionais. ${ }^{11}$

No entanto, também é verdade que, em seus limites, as vantagens da existência de terras naturalmente férteis associadas à extração de excedentes camponeses estão sendo contrabalançadas progressivamente pelo aumento dos custos de transporte, armazenamento e distribuição, os quais por sua vez abrem caminho para a produção baseada na renda diferencial do tipo II, dependente de produtos agroindustriais.

A agricultura brasileira foi duplamente redefinida na década de 70 Primeiramente, pela internacionalização do capital agroindustrial que viu no Brasil um dos mercados mais privilegiados para equipamentos e insumos químicos. Isto estava ligado ao estímulo a produtos não-tradicionais para as economias metropolitanas, particularmente a soja para ração animal,

\footnotetext{
${ }^{10}$ Para um resumo sucinto, ver Cardoso, F. H. Autoritarismo e democratização, Paz \& Terra, 1975.

${ }^{11}$ Para o caso da Amazônia, ver The Prontier and the State in Brazil; a Case-Study of the Amazon, Stanford, 1979. Os cerrados são constituídos por terras planas não cultivadas anteriormente, que requerem correção química dos solos, mas são particularmente adequadas para mecanização.
} 
cultivada não em plantations tradicionais, mas sim por pequenos produtores independentes no Sul. ${ }^{12}$

O elemento crucial no contexto brasileiro era porém a internalização do capital agroindustrial internacional. Na maioria dos casos este capital foi estimulado a estabelecer suas filiais no território brasileiro pelo tamanho do seu mercado. Sobretudo no caso de tratores e indústrias processadoras de alimentos. Entretanto, onde o capital estrangeiro resistiu a esta internalização (por exemplo: fertilizantes) o capital nacional estatal a promoveu. A década de 70 assistiu portanto a uma rápida consolidação de um complexo agroindustrial constituindo uma fração nova e decisiva do capital, mudando também a relação de forças dentro do bloco dominante. ${ }^{13}$

Os interesses agrários tradicionais, cuja posição hegemônica no seio do Estado foi sendo progressivamente deslocado a partir dos anos 30, tinham mantido seu papel dominante dentro do setor agrícola (refletido inicialmente na não-extensão da legislação trabalhista ao campo, e consolidado depois como aliado decisivo contra as ligas camponesas no contexto da derrubada do governo Goulart). Estes interesses estão agora decididamente subordinados aos do capital agroindustrial.

Entretanto, o antagonismo entre estas duas frações não se relaciona com a questão da estrutura agrária; na prática, as maiores propriedades rurais são frequentemente o produto direto do investimento agroindustrial. É na série de medidas voltadas à vinculação do crédito aos investimentos produtivos que esta subordinação do setor tradicional pode ser vista (políticas de zoneamento limitando a cessão de crédito a produtos considerados aptos para uma determinada região; taxas de juros subsidiadas para máquinas agrícolas e insumos), e também no condicionamento do crédito à disposição de investir capital próprio no processo produtivo (a limitação de empréstimos a $60 \%$ dos custos da produção estimada, no caso de grandes produtores). Ademais, a ocupação produtiva está tendo um

${ }^{12}$ Ver International Constraints to Policies for Achieving Increased Food Production in Selected Countries, de Gonzalo Arroyo, Groupe de Recherches Sociologiques, Université de Paris, 1977.

${ }^{13}$ Para uma visão mais ampla do caso brasileiro, ver Estado e classes sociais na agricultura brasileira, de Bernardo Sorj, Zahar, 1980. Aqui estamos usando o conceito "Complexo Agroindustrial" em sentido descritivo. Para um comentário crítico sobre o valor analítico do termo, ver nossas Conclusões. estímulo adicional com a recente deliberação governamental que garante os direitos de propriedade aos posseiros com mais de cinco anos de posse da terra.

O papel decisivo do setor rural como um mercado interno para a acumulação industrial ressurge, neste contexto, porém na forma não prevista de um mercado de insumos para um setor agroindustrial largamente dominado pelo exterior.

Um componente-chave do capital agroindustrial, a indústria de processamento, é entretanto responsável por uma fundamental reestruturação do setor agropecuário, tornando obsoleta a tradicional divisão entre produtos de mercado interno e externo, alimentos e matérias-primas.

O efeito da indústria de processamento é a transformação progressiva de todos os produtos agrícolas em matérias-primas, inclusive a produção alimentar. Além disso, com a criação de novos mercados internos para culturas de exportação (álcool de cana-de-açúcar, óleo comestível de soja) e a integração de produtos alimentares básicos ao rol dos insumos agroindustriais (milho para ração animal, leite para iogurtes/queijos, produção de frangos em massa para o mercado de congelados, mandioca para álcool), a tradicional dicotomia mercado interno $\mathrm{x}$ mercado externo, produtos nobres $\mathrm{X}$ produtos alimentares básicos é rompida, e com ela a concomitante setorialização da agricultura em "tradicional" e "moderna".

Da mesma forma, a ideia de que o setor agrícola é algo de "separado", investido de um "caráter externo" - ideia esta que é o ponto de partida comum tanto para a linha do "feudalismo x capitalismo" quanto para a da "articulação" - vem abaixo com a transformação do setor agrário no locus da realização do capital agroindustrial. ${ }^{14}$

Embora a ascensão da produção agroindustrial não tenha tomado uma direção específica em termos de estrutura agrária, ela tem como precondição a rejeição do crescimento extensivo, e a promoção da produção intensiva, correlacionada à absorção dos insumos agroindustriais.

\footnotetext{
${ }^{14}$ Mais do que isso, como será desenvolvido num futuro trabalho, o próprio setor agrícola se dissolve e transforma sucessivamente na acumulação industrial, sob a forma especifica de agroindústria. Esta, mais do que a geração dos empreendimentos capitalistas rurais, é, de fato, a forma capitalista da produção agrícola. Cf Farming and Capitalism: The Industrial Appropriation of Agriculture, por D. Goodman, B. Sorj, J. Wilkinson (em preparação).
} 
Nossa análise do programa de modernização do governo brasileiro para o pequeno produtor tradicional do Nordeste, conhecido como POLONORDESTE, que será objeto desta obra, ganha significado a partir desta nova subordinação da agricultura ao capital agroindustrial.

Este Programa ${ }^{15}$ que foi criado em fins de 1974, divide seus recursos entre projetos de colonização, irrigação e desenvolvimento rural integrado (PDRI), todos direcionados para o pequeno produtor do Nordeste.

Nos anos iniciais, os projetos de colonização e particularmente os de irrigação receberam uma parte desproporcional dos recursos, e o Programa POLONORDESTE, como um todo, arriscou-se a funcionar como um simples mecanismo de transferência de fundos para as instituições que tradicionalmente dominavam a intervenção estatal no setor agrário do Nordeste - DNOCS, CODEVASF e INCRA. ${ }^{16}$

Entretanto, isto refletiu em parte a não-absorção inicial da inovação representada pelos projetos de desenvolvimento rural integrado (PDRI). Tais projetos, paralelamente às propostas de mesmo nome do Banco Mundial, visavam à modernização em larga escala dos pequenos produtores em áreas selecionadas, através de uma intervenção integrada ao nível das unidades de produção (crédito, assistência técnica, comercialização, etc.) e ao nível da infraestrutura econômica (rodovias vicinais, eletrificação) e social (educação, saúde).

Em 1980, 75\% dos recursos do POLONORDESTE foram absorvidos por esses PDRI, os quais, em contraste com os projetos de colonização e irrigação, baseavam sua intervenção nas estruturas socioeconômicas já existentes nas áreas rurais. Em todo o Nordeste, cerca de 43 projetos distintos estavam em processo de execução. ${ }^{17}$

O Banco Mundial, que por volta de 1980 estava envolvido em seis desses projetos, e o Banco Interamericano de Desenvolvimento (BID) que, por sua vez, participava de cinco projetos, certamente influenciaram esta

${ }^{15}$ O Capítulo Um situará as origens deste Programa na dinâmica da política estatal para o Nordeste.

${ }^{16} \mathrm{Em} 1976$, o DNOCS e a CODEVASF receberam Cr\$ 1.342,9 milhões contra Cr\$ 713 milhões para os PDRI.

${ }^{7}$ Os dados desta seção foram extraídos de Políticas do Estado e desenvolvimento rural integrado no Nordeste, por Yves Chaloult e outros de 1980. mudança de prioridades que privilegiou os PDRI no âmbito do POLONORDESTE. Também está claro que, dentro do PDRI, a alocação de recursos privilegia, de forma crescente, os subprojetos voltados para uma intervenção direta na pequena unidade de produção. Os recursos para a modernização da infraestrutura em geral naquelas regiões selecionadas para os PDRI - modernização esta que naturalmente beneficia, em primeira instância, as forças sociais dominantes destas regiões - apesar de ainda representarem uma significativa proporção do total, têm declinado ao longo dos anos, em favor dos subprojetos especificamente dirigidos à modernização do pequeno produtor. Os subprojetos desse segundo tipo absorveram $42,3 \%$ do total de recursos, contra 33,6\% destinados à infraestrutura econômica em geral.

Em 1980, cerca de 140.000 pequenos produtores de todo o Nordeste estavam recebendo os benefícios dos serviços de extensão rural, com mais de 30.000 já integrados ao circuito de crédito oficial. No total, aproximadamente 618.000 ha de áreas de lavouras e mais de meio milhão de animais do setor da pequena produção foram incluídos no âmbito dos serviços de extensão rural. Com isso, fica claro que o POLONORDESTE representa potencialmente um fator decisivo na transformação da estrutura agrária no Nordeste do Brasil.

Entretanto, apesar de não subestimar a importância da análise dirigida ao significado específico deste programa como elemento estratégico da intervenção estatal sobre a secular problemática do atraso da região nordeste do país, nem a importância de uma análise voltada à delimitação das contradições internas do programa, o nosso objeto de estudo é ao mesmo tempo mais preciso e mais geral.

Nossa preocupação como o POLONORDESTE deriva da oportunidade ímpar que este Programa oferece para uma análise da transformação do processo de trabalho da tradicional exploração familiar quando esta é submetida a uma política de modernização.

Assim, o significado do POLONORDESTE não é redutível à questão, ainda que importante, de sua eficácia enquanto política explicitamente dirigida à transformação econômica do setor minifundiário do Nordeste, visando à sua eliminação como problema social. Além do mais, uma rica 
literatura sobre este tema específico vem sendo rapidamente acumulada com uma série de importantes avaliações técnicas já publicadas. ${ }^{18}$

Tomaremos como ponto de partida a tese que, quaisquer que sejam as especificidades da política regional ou setorial para a agricultura, os parâmetros ou a forma desta intervenção estão sendo agora definidos segundo os termos estabelecidos pela subordinação da produção agrícola à agroindústria.

As estratégias básicas de intervenção no setor de pequena produção do Nordeste têm, desta forma, um significado mais que regional. Apesar de um programa de modernização do pequeno produtor de âmbito nacional, modelado a partir do POLONORDESTE, não ter sido adotado como política governamental, ${ }^{19}$ não é acidental o fato de que o único elemento crucial desta estratégia - o estímulo à integração ao crédito orientado oficial através de taxas de juros e limites de financiamento diferenciados para favorecer pequenos produtores - agora esteja sendo estendido como parte da política nacional.

A relevância de nosso tema não se limita, entretanto, à possibilidade de sua extrapolação para o setor da pequena produção brasileira como um todo, mas está relacionada também à sua articulação com o tema mais amplo da exploração familiar e a agroindústria, que ocupa presentemente lugar central nas discussões nos países "metropolitanos".

Ao fixar nossa análise neste nível, estamos levando em conta a internacionalização da divisão do trabalho agrícola referida anteriormente, e em particular os efeitos da recente internacionalização no contexto brasileiro. Embora extrapole os limites do presente estudo uma análise do impacto geral deste desenvolvimento sobre as formações sociais "dependentes" e sua especificidade, podemos afirmar que um debate teórico comum sobre o tema do capitalismo na agricultura está se tomando cada vez mais viável.

${ }^{18}$ Cf. Política agrícola no Nordeste e Desenvolvimento rural do Nordeste, a experiência do POLONORDESTE, por Yoni Sampaio e outros, PIMES, 1978 \& 1980. Também A experiência em desenvolvimento rural integrado no Nordeste brasileiro, Yves Chaloult e outros. Rio Grande do Norte, 1980, CEPA-RN; e para o caso da Bahia Uma avaliação de programas governamentais para agricultores de baixa renda por J. Wilkinson, CEPA-Ba. Cf. nossa discussão deste tema no Capítulo Um.

${ }^{19}$ Cf. nossa discussão no Capítulo Um.
Um reflexo disto é a crescente convergência entre as discussões no Brasil e no exterior e o declínio da especificidade latino-americana ou problemática terceiro-mundista nos debates atuais sobre a agricultura brasileira. $^{20}$

Além disso, julgamos que o impacto peculiarmente concentrado da subordinação da tradicional exploração familiar à agroindústria, no caso nordestino, permite uma privilegiada visão das transformações do processo de trabalho provocadas por este tipo de modernização.

Isto, por sua vez, contempla-nos com elementos para avaliar a utilidade do conceito de "subordinação real", que domina as atuais discussões no Brasil e na Europa, o que nos permitiu esquematizar, na Conclusão, as bases para a crítica deste conceito.

Entretanto, nossa capacidade de generalizar as conclusões de nossas análises empíricas ao nível de uma crítica teórica depende sobretudo de uma colocação apropriada do objeto do estudo, e de uma correta caracterização de suas especificidades. Assim, o Capítulo Três é dedicado a uma detalhada descrição das características do setor da pequena produção do Nordeste, e na Segunda Parte tomamos o cuidado de basear nossos trabalhos de campo em três projetos contrastantes dentro do POLONORDESTE, o que, além de captar as peculiaridades da estrutura socioeconômica do Nordeste rural, permite isolar aqueles elementos que representam efeitos estruturais da subordinação à agroindústria.

Embora estejamos privilegiando o tema geral das relações entre pequeno produtor e agroindústria, ao invés de abordagens mais específicas, regionais ou programáticas, que a nosso ver teriam menor interesse teórico, nossas conclusões têm implicações práticas para a avaliação da eficácia de um programa de modernização tal como o aplicado no Nordeste.

Mais do que isso, por não ser o Nordeste atípico no contexto da pequena produção no Terceiro Mundo, e por ser o POLONORDESTE, em todos os seus aspectos essenciais, convergente com a estratégia de desenvolvimento rural integrado do Banco Mundial para o pequeno produtor, ${ }^{21}$ tais conclusões podem ser estendidas para além da problemática do Nordeste brasileiro.

${ }^{20}$ Cf. nossa discussão no Capítulo Um.

${ }^{21}$ Ver discussão no Capítulo Um. 
Apesar do nosso tema ser o processo de trabalho da tradicional exploração familiar submetida à agroindústria, e não uma avaliação do modelo dos programas de desenvolvimento rural, nosso tratamento é suficientemente específico para a região, de forma a poder contribuir para a significativa literatura acumulada neste campo. ${ }^{22}$

Este livro está dividido em duas grandes seções, com três capítulos cada. Na primeira seção, começamos por identificar o conceito predominante de pequeno produtor tradicional ao nível do Estado e ao nível acadêmico, delineando a influência das formulações "metropolitanas" e do Banco Mundial na forma como repercutem nos debates no país. Sustentamos que a convergência básica destas abordagens resulta de uma incapacidade para conferir status teórico ao papel desempenhado pelo trabalho não-familiar.

No Capítulo Dois, esta falha é identificada como uma consequência da falsa polarização estabelecida pelo debate clássico da Diferenciação Camponesa, o qual é submetido a uma revisão crítica. O Capítulo final da Primeira Parte tenta interpretar o setor da pequena produção do Nordeste - o público do POLONORDESTE - captando sua heterogeneidade estrutural e explorando dados secundários sobre o caráter de sua dependência da oferta de trabalho extrafamiliar.

A Segunda Parte consiste em três detalhadas análises dos efeitos diferenciais da estratégia de modernização, a partir de projetos escolhidos em função de sua representatividade como precondição de sua relevância para a compreensão da problemática geral de subordinação dos pequenos produtores à agroindústria.

$\mathrm{Na}$ Conclusão, sumarizamos as implicações específicas da análise para uma avaliação do POLONORDESTE como solução para o pequeno produtor do Nordeste, e situamos as conclusões no contexto de uma revisão crítica das principais teses dos defensores do complexo agroindustrial.

${ }^{22}$ Cf. Feder E. The New World Bank Program for the Self Liquidation of Third World Peasantry, JPS, vol. 3. Technological Change and Peasants in Latin America, por Alain de Janvry e Luis Grouch. Univ. da California, 1980; La modernización de la agricultura mexicana por Cynthia Hewitt de Alcantara, Siglo Veintiuno, 1978; The World Bank and Agricultural Development, por Richard Stryker, World Development, 7, 1979.

\section{Primeira parte}

\section{Capítulo um - O conceito de "pequeno produtor"}

\section{A política governamental e o minifúndio antes do POLONORDESTE}

Com a elaboração do Programa POLONORDESTE, o conceito do "pequeno produtor" no contexto brasileiro adquiriu uma dimensão original. Antes, quer no contexto mais radical do início da década de 60, quer no âmbito dos esforços cuidadosamente delimitados da política do PROTERRA para o Nordeste, que antecedeu o POLONORDESTE, ${ }^{1}$ as preocupações com a questão da distribuição de terras em favor do setor minifundiário podem ser essencialmente reduzidas a dois pontos.

A redistribuição de terras era vista ou como uma questão sociopolítica baseada em reivindicações por justiça e democracia (caso do movimento em defesa das Ligas Camponesas), ${ }^{2}$ ou como uma medida econômica para acabar com o latifúndio e abrir caminho para o desenvolvimento de uma agricultura capitalista baseada em empreendimentos agropecuários de tamanho médio (o programa político do Partido Comunista Brasileiro adota esta posição, ${ }^{3}$ como o fizeram, em um contexto restrito, os técnicos da SUDENE). ${ }^{4}$

A política governamental no período pós-64, embora tenha mantido viva a ideia da reforma agrária no papel e mesmo em termos organizacionais $^{5}$, optou por uma estratégia de estímulo à modernização do latifúndio, essencialmente através do crédito subsidiado. As soluções tentadas para o setor minifundiário consistiram em programas de

${ }^{1}$ Programa de Redistribuição de Terras e de Estímulo à Agroindústria do Norte e do Nordeste - Programa federal elaborado no auge da terrível seca de 1970.

2 Para uma avaliação sucinta, Cf. Peasant Leagues in Brazil, de Clodomir Moraes in Agrarian Problems and Peasant Land Movements in Latin America ed. R. Stavenhagem, Anchor Books, 70

${ }^{3}$ Cf. Clodomir Moraes, Op. cit.

${ }^{4}$ Superintendência para o Desenvolvimento do Nordeste, cf. o documento básico elaborado sob a supervisão de Celso Furtado, chamado Documento do Grupo de Trabalho para o Desenvolvimento do Nordeste (GTDN), 1959.

${ }^{5} \mathrm{O}$ Estatuto da Terra foi sancionado após o golpe militar e o Instituto de Reforma Agrária, mais tarde conhecido como INCRA, foi mantido. 
colonização que encorajavam a migração para as regiões de fronteira. O documento diretivo do INCRA "Os problemas fundiários na estratégia do desenvolvimento e da segurança", ${ }^{6}$ enuncia a política de forma particularmente crua quando discute o caso do Rio Grande do Sul:

A solução para o estado é a extinção dos minifúndios e o remembramento de suas áreas (p. 5).

O objetivo de tal política é igualmente explícito:

a criação de uma classe média rural, com recursos para participar no contexto socioeconômico do país (p. 6).

A estratégia da SUDENE para o Nordeste, embora mais progressista em sua apresentação, tinha proposto basicamente a mesma política. A migração do setor minifundiário para as regiões de fronteira do Maranhão foi projetada como a solução para o Sertão, enquanto que para a zona da Mata foi proposto um programa de redistribuição de terras parcial e pacífico, destinado a criar unidades de produção modernizadas de tamanho médio voltadas para o mercado interno.

O programa PROTERRA para o Nordeste, na medida em que chegou a enfrentar a questão da redistribuição de terras, ${ }^{8}$ adotou os princípios estabelecidos pela SUDENE para a área fértil da zona da Mata, razão pela qual o tamanho médio da terra redistribuída foi de 80 ha em Pernambuco. No Sertão árido do Ceará, o tamanho médio foi de 188 ha.

Portanto, ao longo de todo este período, paralelamente ao chamado modelo "prussiano", de "modernização conservadora" diretamente perseguido para transformar o setor latifundiário, há uma preocupação constante com a necessidade de se criar uma "classe média rural" de produtores capitalistas de tamanho médio. Este objetivo deveria ser

${ }^{6}$ Os problemas fundiários na estratégia do desenvolvimento e de segurança (sem data).

${ }^{7}$ Cf. Documento GIDN já citado.

${ }^{8}$ Menos de 1.000 famílias foram beneficiadas com a distribuição de terras, como resultado deste programa.

${ }^{9}$ Adotado no debate brasileiro a partir da caracterização feita por Lênin da variante alemã da penetração capitalista que favoreceu uma transformação interna do latifúndio mais do que uma divisão dele que viesse a estimular a diferenciação capitalista com base na exploração familiar (a "via americana"). Cf. The Agrarian Programme, de Lênin. alcançado, principalmente, através da eliminação do setor minifundiário, ${ }^{10}$ se bem que ocasionalmente se conceba sua implementação às expensas das propriedades improdutivas.

\section{O contexto da estratégia do POLONORDESTE}

Com o POLONORDESTE, o setor minifundiário é encarado pela primeira vez do ponto de vista de seu potencial produtivo existente. Um amplo espectro de fatores pode ser mencionado para explicar esta mudança de orientação explícita, que, como a política subsequente deixou claro, não ficou limitada somente ao Nordeste. ${ }^{11}$

O estímulo imediato para a elaboração de uma nova estratégia para o Nordeste foi o fracasso específico do Programa PROTERRA em confrontarse com os grandes proprietários e implementar uma política de diversificação na zona da Mata.

Este fracasso, entretanto, foi acompanhado da descoberta de um novo Nordeste cuja diversidade não estava mais reduzida ao antigo trinômio "Sertão/Agreste/Mata". O novo mapeamento do Nordeste, que passou a ser a marca registrada do POLONORDESTE, estabelecia agora cinco divisões - os Vales Úmidos, que incluíam doze áreas prioritárias; os Planaltos Úmidos incorporando seis zonas prioritárias; as Regiões Áridas com três áreas potenciais para desenvolvimento; os Tabuleiros Costeiros, desde o Rio Grande do Norte até o extremo-sul da Bahia, e a região Pré-Amazônica, incluindo a colonização promovida pela SUDENE e pelo governo do Maranhão. ${ }^{12}$

Esta identificação de áreas de desenvolvimento potencial vem sendo aperfeiçoada nos anos recentes por um elaborado zoneamento segundo a adequação de produtos, o qual por sua vez define critérios para a liberação de crédito e de subsídios estatais. Tal mapeamento, longe de representar

${ }^{10}$ Este é o significado do critério da unidade econômica - modelo usado pelo INCRA para definir as condições mínimas de viabilidade econômica. No caso da Bahia, a reestruturação com base neste critério poderia eliminar $70 \%$ do setor minifundiário.

${ }^{11} 350.000$ pequenos produtores no Paraná foram incluídos num programa semelhante, e as condições especiais de crédito do POLONORDESTE foram agora generalizadas em escala nacional.

${ }^{12}$ Para uma excelente descrição, cf. Política agrícola no Nordeste. Yoni Sampaio e outros, BINAGRI. 1979. 
uma verdadeira descoberta, refletiu o potencial crescente de subordinação da agricultura à tecnologia industrial. Isto vem sendo acelerado com a implantação de indústrias de sementes selecionadas, fertilizantes e defensivos no Nordeste, ao lado da instalação de indústrias de processamento, especialmente para tomate, frutas cítricas e mandioca.

A importância política e social desta reorientação da estratégia de modernização fora da zona da Mata deriva da relativa independência que ela estabelece entre áreas potencialmente dinâmicas para a produção e as estruturas latifundiárias tradicionais.

Ao lado da inabilidade em confrontar-se com a estrutura latifundiária tradicional através dos mecanismos de redistribuição de terras, também ficou reconhecido o fracasso do componente "crédito" do Programa PROTERRA em promover a modernização destas grandes propriedades, com o seu desvio para a compra de terras e investimentos urbanos. ${ }^{13}$

Esta crítica veio acompanhada por um ataque renovado e mais geral ao caráter improdutivo do latifúndio, que emergiu das instituições de planejamento governamental, combinando uma análise da viabilidade produtiva do setor dos pequenos produtores com o argumento de que quase todos os produtos alimentares básicos provinham de propriedades abaixo de 50 ha - com uma crítica paralela à distribuição do crédito, que alocava apenas $20 \%$ no setor da pequena produção. ${ }^{14}$

Embora não interesse, neste momento, atribuir pesos a estes diferentes elementos, e excluindo por enquanto consideração das influências internacionais, é claro que a conjunção destes fatores tornou possível uma nova orientação econômica e política para o setor do pequeno produtor.

Mais do que isso, tal conjunção de fatores possibilitou uma convergência de interesses conjuntural entre a política governamental e o que pode ser chamado de "forças progressistas" no seio das instituições de planejamento governamentais. Apesar de os argumentos da corrente

${ }^{13}$ Cf. Denúncias jornalísticas atuais e a ampla crítica contida em Política agrícola no Nordeste, citada anteriormente.

${ }^{14}$ Baseada essencialmente em interpretações do Censo Agropecuário de 1970. Mais adiante, neste Capítulo, será discutida a ambiguidade implícita na definição do setor de pequena produção exclusivamente em termos do tamanho da exploração. progressista possivelmente não visarem a isto a defesa da viabilidade do setor da pequena produção na prática justificou políticas que deslocaram a atenção da reforma agrária e permitiram a consolidação de um programa limitado à provisão de ajuda financeira e técnica. Analisaremos as principais diretrizes desta estratégia progressista após descrever o perfil básico do POLONORDESTE.

\section{O conceito de "pequeno produtor" para o POLONORDESTE}

Nosso propósito não é avaliar a importância relativa do POLONORDESTE no âmbito das políticas globais para o Nordeste. Também não iremos examinar suas ambiguidades na definição e implementação. Ambos esses temas já foram analisados extensivamente por alguns autores, inclusive pelo autor deste texto. ${ }^{15}$

Aqui nos limitaremos ao conceito de "pequeno produtor" na forma como emerge dos documentos diretivos, juntamente com as características essenciais da estratégia elaborada para a intervenção neste setor.

Nos documentos do POLONORDESTE, a estrutura agrária é apresentada como um contínuo quantitativo de unidades de produção, estando o setor minifundiário localizado no seu extremo inferior. Em consequência fica excluída qualquer interpretação do minifúndio como expressão de relações de classe específica no meio rural. Uma grande parte do proletariado rural, dessa forma, é eliminada por definição, reemergindo sob a rubrica geral de "pequenos produtores".

O critério inicial desenvolvido nos documentos diretivos para caracterizar o setor do pequeno produtor foi o fator quantitativo do tamanho da propriedade. A partir de um máximo inicial de 200 ha, que teria incluído 97\% de todas as propriedades do Nordeste, o limite superior geralmente fixado nos últimos documentos é de 50 ha para agricultura e 100 ha para pecuária. ${ }^{16}$ Isto é um pouco alto quando comparado com o modelo do INCRA para uma unidade de produção viável, que oscila em tomo de 35

\footnotetext{
${ }^{15} \mathrm{Cf}$. Bibliografia citada na Introdução.

${ }^{16}$ A informação deste parágrafo foi retirada das Diretrizes Gerais para o POLONORDESTE. Brasília, 1975 e 1977 (mimeo)
} 
ha. ${ }^{17}$ Todavia, isto reflete a consolidação de uma clara orientação voltada para o pequeno-para-médio produtor.

Esta tendência fica confirmada com a introdução do critério de rendas, que acabou sendo fixado em tomo de dois salários mínimos regionais - embora também tal critério, no contexto do Nordeste, tenha aberto a perspectiva para uma orientação voltada aos pequenos produtores relativamente "remediados".

Entretanto, somente nos documentos mais recentes aparece uma definição "sociológica" mais precisa. ${ }^{18}$ Esta nova definição compreende dois elementos.

A renda tal como definida acima, na faixa de dois salários mínimos, deve ser entendida como renda total e não simplesmente renda agrícola. E, em segundo lugar, a unidade de produção deve estar baseada "essencialmente no trabalho familiar".

Desta forma, delineia-se um claro modelo para definir os beneficiários privilegiados pelo Programa. Eles devem compreender preferencialmente as unidades de produção familiar que sejam autossuficientes tanto em termos de renda quanto de trabalho, mas que não gerem excedentes para investimento. Ou melhor, o objetivo do Programa é uma seleção de beneficiários visando a criar uma tal unidade de produção autossuficiente.

No Capítulo Três, iremos analisar o grau em que este modelo se baseia numa compreensão realista da pequena produção rural familiar no contexto do Nordeste.

\section{O conceito de "pequeno produtor" como um consenso do sistema de planejamento estatal}

A partir de um ponto de vista muito mais radical, podemos encontrar um modelo análogo no Relatório Final do Grupo de Trabalho para Promoção de Agriculturas de Baixa Renda, de 1978. Este documento

\footnotetext{
${ }^{17}$ Este modelo define o tamanho mínimo do estabelecimento para a sobrevivência da família a partir da renda gerada na exploração, tomando em conta variações na fertilidade do solo e práticas culturais.

${ }_{18}$ Ministério da Agricultura. Relatório final do Grupo de Trabalho para a Promoção de
} Produtores de Baixa Renda. Brasília, 1976 (mimeo). representa, em síntese, o pensamento das forças progressistas dentro do Sistema de Planejamento Estatal, e consequentemente a coincidência de pontos de vista representa um consenso mais básico com respeito à definição do setor minifundiário.

Sem dúvida, as propostas deste Grupo de Trabalho não participavam das ambiguidades e seletividade do POLONORDESTE em relação ao setor minifundiário. Reivindicam uma ampla intervenção a nível nacional voltada para aquelas propriedades que estejam abaixo do modelo econômico básico do INCRA; enfatizam a necessidade de organizar estes pequenos produtores, e solicitam uma política de expropriação para beneficiar as menores dentre estas propriedades.

Todavia, o setor minifundiário é essencialmente caracterizado como um setor produtivo. A existência de trabalhadores rurais não é negada. Pelo contrário, eles aparecem claramente como um dos dois componentes básicos das massas rurais. Entretanto, na análise elas são estritamente separadas do próprio setor minifundiário que é prioritariamente focalizado no programa proposto, e que é considerado exclusivamente em termos de unidades de produção. ${ }^{19}$

É na análise dos "fatores de produção" - terra, trabalho e capital que estes paralelos com o POLONORDESTE emergem mais claramente. Se excluirmos a abordagem mais desafiadora da escassez de terra realizada pelo Grupo de Trabalho (o POLONORDESTE tem uma preferência marcada pelo incremento da produtividade, ao invés de reforma agrária), o problema do minifúndio é definido essencialmente como excesso de trabalho em confronto com falta de capital. A mão de obra é definida como "abundante e ao mesmo tempo ociosa ou subempregada" ${ }^{20}$ Neste contexto, a provisão de crédito oficial poderia simultaneamente livrar o "pequeno produtor" da dependência do capital mercantil, e permitir um cultivo mais intensivo, absorvendo-se dessa maneira a "mão de obra excedente".

Podemos então definir como convergentes as abordagens destes dois programas, em seu objetivo comum de criar as condições de se alcançar a harmonia, essencial supostamente possível de existir entre mão de obra

${ }^{19}$ Há uma referência aos trabalhadores rurais com lotes de terra (p. 47), mas isto é visto como uma questão secundária e não integrada no âmbito da abordagem estratégica.

${ }^{20}$ Op cit., p. 12. 
familiar, renda e terra. A orientação explícita não é mais a criação de uma "classe média rural" de produtores capitalistas, mas a manutenção e fortalecimento das unidades de produção familiares de pequena escala já existentes.

\section{Convergência com os debates acadêmicos da década de 70}

Os documentos produzidos pelo "Grupo de Trabalho para Promoção dos Agricultores de Baixa Renda" ${ }^{21}$ são particularmente instrutivos, porque representam a incorporação ao nível do Sistema de Planejamento Estatal de certas concepções básicas derivadas dos debates acadêmicos da década de 70. Estes debates estão agora bem documentados, ${ }^{22}$ e aqui bastará um sumário deles.

Em essência, a análise dos dados do Censo iniciada por Francisco Sá e acelerada com a publicação do Censo de 1970 argumentou que o aumento da demanda de alimentos para o mercado interno não produziu um processo de diferenciação, tendo sido coberto pela expansão numérica de agricultores que produzem essencialmente para subsistência, cujo "excedente" forma a base da oferta de alimentos para o meio urbano. ${ }^{23}$

Uma posição contrária manifestou-se, principalmente nos trabalhos de Castro e Forman, ${ }^{24}$ enfatizando o que Goodman definiu sinteticamente como um "modelo de especialização", e defendendo o ponto de vista de que o setor de alimentos tendeu a uma predominância de unidades produzindo especificamente para o mercado, ou, segundo Forman, ao estabelecimento de uma agricultura em escala classicamente capitalista. Entretanto, estas posições foram defendidas com pouco rigor empírico, e foi a outra tese que

\footnotetext{
${ }^{21}$ Cf. também o Programa Nacional para os Produtores de Baixa Renda. A definição do setor minifundiário essencialmente como um setor de produção, que se percebe bem na versão inglesa "farmer", é indicativo de sua orientação.

${ }^{22}$ Cf. especialmente Goodman, D. E. Rural Structure, Surplus Mobilization, and Modes of Production in a Peripheral Region: the Brazilian Northeast. Journal of Peasant Studies, 5(1), 1977.

${ }^{23}$ Sá, Francisco. O desenvolvimento da agricultura nordestina e a função das atividades de subsistência. Estudos CEBRAP 3, São Paulo, 1973.

${ }^{24}$ Castro, Antônio Barros de. 7 ensaios sobre economia brasileira, Forense. 1969 e Forman, Shepard. Camponeses: sua participação no Brasil, Paz \& Terra, 1979.
}

veio a se tornar o senso comum dos analistas progressistas, recebendo sua formulação clássica no texto de Brandão $\operatorname{Lopes}^{25}$ :

a oferta de alimentos para o meio urbano é composta basicamente de inumeráveis pequenos excedentes provenientes dos minifúndios de subsistência [...e] se expande independentemente do comportamento de mercado ou de suas tendências...

Reservaremos nossa crítica substantiva a esta posição para o Capítulo Três. $^{26}$ Aqui, entretanto, vale a pena fazer alguns comentários metodológicos sobre o debate. A despeito do aparente rigor da discussão, que revolveu exaustivamente os dados do Censo de 1970, a unidade básica de análise foi extremamente ambígua. Conceitualmente, o argumento dependeu especificamente da persistência da produção de subsistência como tendência predominante, como fica claro a partir da citação acima de Lopes, repetida nos documentos do Grupo de Trabalho. ${ }^{27}$ Entretanto, a defesa empírica foi baseada em dados referentes a propriedades que variavam de 0 a 50 ha. A flexibilidade de uma tal interpretação quantitativa torna-se clara quando é reconhecido que $75 \%$ de todo fertilizante químico é utilizado em propriedades abaixo de 50 ha, e que estas propriedades absorvem, além disso, cerca de $33 \%$ de todos os tratores usados no setor agrícola. $^{28}$

Além disso, ao se discutir a questão da oferta de alimentos para os meios urbanos - e, em consequência, as condições de reprodução da força de trabalho urbana - empregaram-se dados limitados à produção, e não, como deveria ser, cifras relativas à produção comercializada nos principais mercados urbanos. E, finalmente, o argumento deve muito de seu peso ao emprego de dados agregados, com o que, por definição, tende-se a minimizar processos específicos de diferenciação. ${ }^{29}$

\footnotetext{
${ }^{25}$ Desenvolvimento e migrações. CEBRAP 6, 1973.

${ }^{26}$ Para uma crítica inicial, ver, do Autor, Uma avaliação de programas governamentais para agricultores de baixa renda. Salvador, CEPA-Ba, 1978.

${ }^{27}$ Esse tipo de produtor... preocupa-se fundamentalmente com o auto-abastecimento de sua família, sendo sua participação individual no mercado bastante reduzida. (Op. cit., p. 6.).

${ }_{28}^{28}$ Dados do Censo Agropecuário de 1975.

${ }^{29}$ Iremos analisar esta questão com maiores detalhes em nossa análise do texto da BINAGRI sobre o Nordeste, no Capítulo Três.
} 
Esta concepção do setor minifundiário ou de subsistência deriva do contexto mais amplo do debate dos anos 70 o qual, particularmente influenciado pela análise de Sá, da crise do latifúndio tradicional, estava preocupado com a redefinição dos termos de articulação entre o minifúndio e o latifúndio. Foi argumentado que a estagnação do setor exportador não tinha levado a um declínio da polarização latifúndio x minifúndio, em termos da estrutura agrária. Ao invés disso, a relação entre os dois tinha sido reestruturada. $\mathrm{O}$ que tinha sido anteriormente uma articulação ao nível da força de trabalho (com o minifúndio funcionando como uma reserva de força de trabalho e como a base para sua reprodução barata) havia mudado agora para uma articulação a nível de mercado. $\mathrm{O}$ minifundiário, como "semiproletário", torna-se agora "pequeno produtor" (um termo que veio a dominar crescentemente não só a literatura oficial como também a acadêmica), dentro do latifúndio. O latifundiário, então, compensa o declínio nos mercados externos pelo arrendamento de sua terra, combinando um novo status rentista como o de capitalista mercantil, controlando o acesso ao crédito e ao mercado. ${ }^{30}$

Assim, dois elementos básicos definem os termos deste debate. Há uma preocupação em rejeitar a existência de qualquer processo de diferenciação social afetando o setor que produz para os mercados urbanos, entendida esta diferenciação nos termos clássicos do desenvolvimento de explorações especificamente capitalistas. ${ }^{31} \mathrm{Em}$ segundo lugar, há a tentativa de demonstrar a subordinação continuada do minifúndio, visto agora como a unidade de produção vital para o mercado doméstico, cujo excedente é expropriado pelo latifundiário, transformado em capitalista mercantil.

O resultado foi que, do começo ao fim deste debate, pouca atenção se deu às relações internas do próprio setor minifundiário. $\mathrm{O}$ conceito de trabalho familiar permaneceu não-problematizado, e a viabilidade potencial de unidades de produção baseadas essencialmente na força de trabalho familiar nunca foi questionada. Na medida em que se localizou um

${ }^{30}$ O Censo de 70 mostrou um declínio no arrendamento e como resultado a relação latifúndio-minifúndio era vista mais em termos de mercado e crédito.

${ }^{31}$ Surgiu um debate também em tomo da questão da proletarização de força de trabalho do setor latifundiário-exportador (cf. Ianni, O. A classe operária vai ao campo. CEBRAP 24, 1976) mas não fez parte desta discussão. problema de trabalho no setor minifundiário, enfatizou-se exclusivamente sua abundância e subutilização. ${ }^{32}$

\section{A estratégia de modernização do pequeno produtor}

Não surpreende pois que não tenha ainda sido tentada nenhuma crítica estratégica ao POLONORDESTE. Tais críticas - da forma como foram feitas e entre elas se inclui um esforço inicial deste autor - concentram-se nas limitações e seletividade do Programa (visto como privilegiando uma pequena minoria do setor da pequena produção, seja com o propósito de estabilizar a produção para o mercado doméstico, seja visando a proporcionar uma base de legitimidade para o regime), ${ }^{33}$ ou apontam problemas na implementação do Programa (benefícios do Programa apropriados por médios e grandes produtores, não ocorrendo na prática um acréscimo substancial na oferta de emprego e na renda). ${ }^{34}$

Entretanto, a dinâmica de um programa de modernização baseado em crédito, voltado para consolidar a pequena produção familiar tradicional, ainda não foi cuidadosamente examinada. A esse respeito é significativo que - apesar da natureza política radical das propostas do Grupo de Trabalho implicando sérios prejuízos para os privilégios da grande propriedade e na promoção da auto-organização entre os pequenos produtores - haja um nítido paralelismo entre as principais linhas de intervenção sugeridas pelo Grupo e a estratégia modernizadora oficial.

Em ambos os casos, o elemento-chave é a necessidade de incrementar a produtividade com base na absorção de insumos modernos, estimulada pelas equipes de extensão rural governamentais e viabilizada pela oferta de crédito oficial subsidiado. Este último elemento é o "lynchpin" deste conceito de modernização.

Nos documentos do Grupo de Trabalho, o crédito oficial é visto essencialmente como um mecanismo para evitar a descapitalização

${ }^{32}$ Novamente os dados para a defesa desta posição derivam do Censo de 70, no qual se nota um processo paralelo de queda no tamanho médio dos estabelecimentos minifundiários e um incremento no número de pessoas ocupadas.

${ }^{33}$ Cf. Chaloult, Yves. Políticas do estado e desenvolvimento rural integrado no Brasil. 1980 (mimeo).

34 Sampaio, Yoni e outros. Desenvolvimento rural no Nordeste: a experiência do POLONORDESTE. PIMES, 1980 e também Wilkinson, John. Uma avaliação... op. cit. 
provocada pela dependência do capital mercantil local, e como o fator crucial que permite a aquisição dos insumos modernos e implementos que conduzem ao aumento da produtividade, à diversificação voltada a produtos mais lucrativos e portanto ao aumento da renda disponível.

Nos documentos do POLONORDESTE, há uma explícita conexão entre a extensão do crédito e a questão do trabalho, ausente da análise do Grupo de Trabalho, coerente com a caracterização do setor minifundiário como sendo de força de trabalho abundante e subemprego. Apesar desta conexão não estar integrada à sua análise mais geral, os documentos do POLONORDESTE reconhecem que a falta de renda força muitos pequenos produtores a abandonar suas parcelas para trabalhar em outras propriedades ou nas cidades. Dessa maneira, o crédito, além de permitir a absorção de insumos modernos, é visto como um elemento essencial para fixar a força de trabalho na própria parcela, e portanto como a chave para o incremento da produção e a consolidação da exploração familiar.

De ambos os pontos de vista, portanto, os efeitos da modernização induzida pelo crédito oficial serão no sentido de garantir a viabilidade do setor do pequeno produtor baseado na força de trabalho familiar.

\section{A estratégia de desenvolvimento rural do Banco Mundial e o POLONORDESTE}

Na discussão anterior, mostramos como a orientação para o pequeno produtor iniciada pelo POLONORDESTE é compreensível em função de fatores específicos da formação social brasileira. Todavia, é difícil não reconhecer a influência do Banco Mundial nesta abordagem, pelo momento em que surgiu e pelo seu conteúdo.

Foi no fim de 1973 que o presidente do Banco Mundial, McNamara, definiu as principais linhas do Segundo Plano Quinquenal do Banco, que deveriam ser orientadas prioritariamente para a pobreza rural, e propôs que o Banco, "em suas recomendações econômicas aos governos, desse particular atenção às políticas setoriais e financeiras que mais afetassem a pobreza rural". No mesmo ano, ${ }^{35}$ de acordo com o documento Rural Development Issues and Options in Northeast Brazil (Questões de desenvolvimento rural e opções para o Nordeste brasileiro):

\footnotetext{
${ }^{35}$ Há aqui, provavelmente, um erro: tratar-se-ia do ano de 1974.
}

O Banco iniciou conversações com o Governo do Brasil com o objetivo de aumentar a proporção dos seus empréstimos para projetos que viessem beneficiar os segmentos de baixa renda de população. Várias missões e atividades se seguiram, com o objetivo de gerar uma bateria de projetos concebidos para incrementar a produtividade dos pequenos produtores. Estes esforços podem ser classificados em três grupos: a) atividades regionais, incluindo o Programa para o Desenvolvimento Rural Integrado de Áreas Prioritárias do Nordeste e o Programa Conjunto de Pesquisas do "Development Research Center" (DRC) do Banco e da SUDENE para conhecer os problemas e a potencialidade dos sistemas da pequena produção. (p.3)

Não fica muito claro se o POLONORDESTE referido no texto foi um produto destes esforços, mas é evidente que, durante o tempo de sua formulação, as missões do Banco Mundial estavam discutindo com o governo a promoção do que o Rural Development: A Document of Sectoral Policy definiu como "planos de desenvolvimento para zonas específicas", 36 do que o POLONORDESTE é um claro exemplo.

Todavia, o documento Rural Development Issues... marca sua distância em relação às políticas do governo brasileiro para o Nordeste tanto pelas suas críticas ao POLONORDESTE quanto pela maior amplitude de suas contrapropostas:

Embora o POLONORDESTE seja um passo à frente encorajador, terá um alcance relativamente limitado. $O$ governo poderia considerar ademais o estabelecimento de uma substancial linha de crédito para pequenos produtores do Nordeste, com acesso limitado ao tamanho da exploração e renda anual abaixo de certos tetos, de forma a prevenir desvios dos fundos para os grandes usuários. Isto incrementará a viabilidade da agricultura de pequena escala e a competitividade dos pequenos produtores... (p. 1.)

De fato, as propostas do Banco Mundial são curiosamente coerentes com as mais radicais do Documento do Grupo de Trabalho, discutidas anteriormente, tanto no âmbito geral das propostas, quanto em relação aos

36 Ademais o diagnóstico da problemática do setor do pequeno produtor é idêntico, enfatizando "a abundância de força de trabalho e a escassez de capital no Nordeste, o trabalho intensivo da pequena produção e a verdadeira limitação de economias de escala exibida pela agricultura...” (p. 1, Op. cit.) 
métodos de intervenção - reforma agrária, cooperativas de pequenos produtores, tecnologia apropriada.

Com o pragmatismo que caracteriza a maior parte da literatura do Banco Mundial, há uma clara afirmação de suas prioridades no início do documento Rural Development Issues...

Embora em termos de equidade, os programas de desenvolvimento rural provavelmente devessem estar voltados à população sem terra, e aos menores proprietários, uma vez que estes grupos constituem o cerne do problema da pobreza rural no Nordeste, o maior potencial para o aumento da produção reside no grupo de pequenos e médios proprietários e parceiros com maior segurança de posse, os quais já têm algum grau de acesso à terra e as seu uso. ${ }^{37}$

Posição idêntica é enunciada no estratégico documento Rural Development..., onde o foco da prioridade é novamente o pequeno produtor independente, sugerindo-se uma série de obras públicas ("public works") como soluções parciais para o problema da massa dos sem-terra. ${ }^{38}$ Neste documento, fica claro que o foco central da política do Banco não é a pobreza rural em si, mas o estímulo à modernização do setor de produção de alimentos, baseado essencialmente, embora não exclusivamente, na pequena produção. ${ }^{39}$ Contra os argumentos de que tal política implica a concentração de recursos em um grupo que controla somente cerca de $16 \%$ da terra agricultável do mundo, assinala-se que "os pequenos produtores frequentemente usam seus recursos de terra com maior eficiência". ${ }^{40}$

A modernização deste setor é para ser alcançada essencialmente através de sua incorporação à estrutura do crédito oficial que proverá condições para a absorção de tecnologia e, com isso, o incremento de produtividade. Além do mais, o crédito é visto como um mecanismo para eliminar os agiotas, e possibilitar um salário para a força de trabalho familiar. $^{41}$

Assim, a estratégia do Banco Mundial e a orientação do POLONORDESTE são virtualmente idênticas. Embora seja possível que

\footnotetext{
${ }^{37}$ Op. cit., p. 2.

${ }^{38}$ Op. cit., p. 30

39 Op.

${ }_{40}$ Op. cit., p. 15.

${ }^{40}$ Op. cit., p. 15.

${ }^{41}$ Op. cit., p. 66.
}

muitos dos detalhes do POLONORDESTE tenham sido influenciados pelas condições para o recebimento dos fundos do Banco Mundial, achamos que esta convergência reflete uma resposta comum a uma mudança de estruturas de poder redefinindo o setor agrícola, tanto em escala mundial quanto internamente à formação social brasileira. ${ }^{42}$

Esta mudança fundamental pode ser descrita essencialmente em termos de uma crescente subordinação do setor agrícola à acumulação industrial, tanto através dos insumos adquiridos pelo agricultor, quanto pelo processamento final de sua produção. Como o eixo do lucro mudou da esfera da própria produção agrícola para os setores da produção de insumos e do processamento, houve uma redescoberta paralela da importância do pequeno produtor independente como fornecedor das matérias-primas e como mercado para os insumos agroindustriais. Como mostraremos em detalhe na Segunda Parte, o significado dos projetos de desenvolvimento rural integrado deve ser visto no contexto do esquema estabelecido por esta nova conjuntura.

No caso brasileiro, é interessante notar como o debate que serviu para redefinir o setor minifundiário como essencialmente de pequenos produtores subordinados ao latifundiário e ao capital comercial forneceu a base para um projeto político "radical", sob a forma do Programa Nacional para os Produtores de Baixa Renda, perfeitamente compatível com a estratégia do Banco Mundial e o complexo agroindustrial.

\section{A agroindústria e os novos termos do debate acadêmico}

Enquanto o debate diretamente gerado pela estratégia corrente do Banco Mundial teve pouco eco no contexto brasileiro, a penetração recente da agroindústria serviu para redefinir os termos do tradicional debate sobre a "diferenciação", e ao fazê-lo, redirecionou as atenções para a questão do pequeno produtor, do "camponês" como ele é preferencialmente chamado no contexto da modernização do setor agrícola.

\footnotetext{
${ }^{42}$ Um trabalho ambicioso neste campo está sendo desenvolvido pelo International Project on Multinationals and Agriculture, dirigido por Gonzalo Arroyo, Paris. Para o caso brasileiro, o relato mais sistemático é o Sorj, B., Estado e classes sociais na agricultura brasileira, Zahar, 1980 e também cf. Muller, Geraldo. Agricultura e industrialização do campo no Brasil. Revista de Economia Política, 2/2, 6, 1982.
} 
A principal característica desta orientação é sua rejeição da clássica tese leninista da diferenciação social expressa na tendência linear para a proletarização. A defesa desta última posição tinha ganho força no contexto dos debates sobre o "boia-fria", particularmente estimulados pela obra $O$ Boia-fria, Acumulação e Miséria, de Maria Conceição d'Incao e Mello. ${ }^{43}$ Generalizações a partir dos dados empíricos sobre expulsões muito difundidas de moradores e agregados do latifúndio foram combinadas com modelos apriorísticos, segundo os quais o desenvolvimento capitalista necessariamente implica um clássico processo de proletarização (Silva) e unificação do mercado de trabalho (Ianni). ${ }^{44}$

A discussão subsequente tem tendido a restringir a ocorrência aumentada do "boia-fria" a um processo específico da "purificação das relações capitalistas nos empreendimentos agrícolas de larga escala". ${ }^{45}$ Esta redefinição da questão da proletarização tem sido ladeada por um crescente reconhecimento da persistência e recriação da produção em pequena escala no contexto da subordinação cada vez maior da agricultura à agroindústria. Isto se vê claramente na Evolução Recente e Situação Atual da Agricultura Brasileira, publicada em 1979, que apresenta a síntese de uma série de projetos regionais de pesquisa juntamente com uma revisão completa da literatura relevante, ${ }^{46}$ e conclui como segue:

(...) podem-se reconhecer três características básicas do desenvolvimento do setor agrícola brasileiro nas três últimas décadas: a) a crescente dependência da agricultura à indústria; b) a desigualdade do processo de penetração do capitalismo no setor; c) a permanência da pequena produção agrícola não-capitalista.

\footnotetext{
${ }^{43}$ Cf. Ed. Vozes, 1976.

${ }^{44}$ Estrutura agrária e produção de subsistência na agricultura brasileira, Ed. HUCITEC, 1978, onde Graziano equaciona a penetração capitalista com o grau em que a expropriação da força de trabalho foi realizada (Cf. p. 252). E Ianni, O. Relações de produção e proletariado rural in Szmrecsányi, T. \& Queda, O. Vida rural e mudança social, Nacional, 1973.

${ }^{45}$ Cf. Sorj, B. Op. cit. e pontos de vista revistos de Graziano Silva em Progresso técnico e relações de trabalho na agricultura, Ed. HUCITEC, 1981, onde ele vê o "volante" ou o trabalhador temporário nas grandes explorações como uma expressão do desenvolvimento limitado do capitalismo.

${ }^{46}$ Castro, Ana Célia e outros. Ed. BINAGRI, 1979. Este trabalho, a nosso ver, ilustra o grau em que os debates no Brasil estão se tomando cada vez mais integrados aos debates internacionais a respeito deste tema, particularmente sob a influência de Vergopoulos, cujo trabalho foi traduzido com o de Amin em 1978.
}

De forma semelhante, num trabalho recente onde tenta uma reinterpretação sistemática do desenvolvimento agrícola à luz da crescente subordinação da agricultura ao complexo agroindustrial, Sorj ${ }^{47}$ faz a seguinte síntese das tendências básicas em curso:

O processo de penetração crescente do capital na base do processo produtivo agrícola determina uma transformação e diferenciação constante das características dos diferentes tipos de empresas agrícolas. Grande parte dos latifúndios se transformam em modernas empresas capitalistas, diferenciando-se cada vez mais dos antigos latifúndios tradicionais assentados na exploração da renda do pequeno produtor. A pequena produção por sua vez ou é marginalizada ou se integra ao complexo agroindustrial, gerando uma camada de pequenos produtores capitalizados.

Este reconhecimento do pequeno produtor capitalizado como um produto direto da crescente penetração do capitalismo na agricultura levou ao reexame do conceito de proletarização, visto como a separação do produtor direto de seus meios de produção. Tal discussão, que tem correspondência direta com a literatura europeia ${ }^{48}$ tem tendido a redefinir o conceito de proletarização em termos da capacidade por parte do capital de estabelecer controle direto sobre o processo de produção, onde o controle jurídico formal permanece com o produtor direto. Este é o sentido em que o conceito aparece em um recente texto de Wanderley, ${ }^{49}$ também numa formulação mais sistemática, em "A Pequena Produção e as Transformações da Agricultura Brasileira", de Graziano da Silva:

É fundamental portanto entender que, do nosso ponto de vista, o conceito de proletarização deve ser interpretado num sentido bastante amplo como o processo da subordinação direta do trabalho ao capital e não simplesmente como a expropriação completa do camponês dos seus meios de produção. ${ }^{50}$

Isto tem importantes repercussões para a análise de projetos de desenvolvimento rural integrado dirigidos ao setor dos pequenos

${ }^{47}$ Op. Cit., p. 12.

${ }^{48}$ Cf. especialmente Bernstein, H. Capital and Peasantry. Review of African Political Economy, 10, 1977, e Faure, C. Agriculture et capitalisme, Anthropos, 1978. Estes autores, mais tarde, são revisados no contexto de nossa análise conclusiva.

${ }^{49}$ O camponês: trabalhador para o capital (mimeo), 1980

${ }^{50}$ Cadernos do CEAS, ${ }^{\circ}$ 9, 1980. 
produtores. Em primeiro lugar, a modernização da produção em pequena escala se liberta da clássica abordagem em termos de "diferenciação", que reduziria tal processo a uma fase de transição em direção à exploração agrícola capitalista baseada no trabalho assalariado. Em segundo lugar, fornece uma base para a análise dos programas de extensão rural e assistência técnica, os quais podem agora ser examinados como veículos privilegiados da adaptação do processo de trabalho no setor da pequena exploração às exigências do capital agroindustrial.

Entretanto, este debate foi limitado pelo que pode ser chamado de uma abordagem economicista ou, talvez melhor, teoricista, e não levou a nenhum reexame da estrutura interna da produção em pequena escala no processo de modernização ou tecnificação.

Isto pode ser exemplificado com dois recentes trabalhos, envolvendo análise de estudos de caso da produção em pequena escala subordinada ao complexo agroindustrial. Não é nossa intenção aqui oferecer uma revisão exaustiva destes trabalhos, mas simplesmente mostrar como o conceito central de "exploração familiar" é usado de forma acrítica, mesmo quando os dados empíricos são suscetíveis de uma análise muito diferente.

Em seu estudo da produção em pequena escala subordinada à Cooperativa Cotia: Cooperativismo e Reprodução Camponesa $a{ }^{51}$ Maria Rita Garcia' Loureiro define os associados da Cooperativa nos seguintes termos:

Os cooperados aqui analisados são basicamente pequenos produtores que possuem ou arrendam pequena parcela de terra, trabalham basicamente com mão de obra familiar e, embora inseridos no mercado, produzem fundamentalmente para sua sobrevivência e não visando o lucro. 52

Porém, a despeito desta tosca afirmação da característica familiar da unidade de exploração (note-se a falta de precisão do termo "basicamente"

\footnotetext{
${ }^{51}$ Loureiro, M. R. G. org. Cooperativas agrícolas e capitalismo no Brasil, Ed. Cortez. Uma importante discussão da característica peculiar do trabalho agrícola, que tenta ir além de um capítulo puramente quantitativo e redefine o problema em termos de trabalho produtivo e não-produtivo, pode ser encontrada no artigo de Mann, S. \& Dickinson, J., Obstacles to the Development of a Capitalist Agriculture. Journal of Peasant Studies, 5(4), 1978. Consultar a Conclusão para uma crítica a este ponto de vista com base nos resultados de nossas próprias investigações.

52 Op. cit., p. 13.
}

que tantas vezes aparece nestes textos), das dez unidades estudadas em detalhe, duas dependem principalmente de força de trabalho contratada (que representa $80 \%$ e $65 \%$ dos custos do trabalho), e, no caso de mais outras três, o custo do trabalho contratado equivale a $49 \%, 41 \%$ e $42 \%$ do total de gastos com trabalho. Portanto, metade de sua amostra, longe de representar "basicamente" o trabalho familiar, depende pelo menos na mesma proporção da força de trabalho assalariada.

José Vicente Tavares dos Santos, em Colonos do Vinho ${ }^{53}$ é o único na literatura brasileira contemporânea que focaliza explicitamente a questão do trabalho familiar como a dinâmica detrás da produção em pequena escala no contexto da subordinação à agroindústria. Assim como a autora anterior, ele enfatiza a primazia do trabalho familiar:

Deve-se iniciar pela observação do processo de trabalho: quem o move é a força de trabalho familiar. (p. 27.)

Ele segue desenvolvendo uma argumentação detalhada, visando a mostrar que a produção é subordinada ao ritmo da oferta de trabalho familiar, encarando explicitamente sua interpretação como uma verificação das proposições centrais da obra de Chayanov. ${ }^{54}$ Independentemente do grau em que tal posição pode ser empiricamente sustentável, é a singularidade desta colônia de produtos italianos que merece ênfase, particularmente com respeito ao controle institucional sobre o trabalho familiar.

Numa descrição muito rica das tradições do casamento na família, ${ }^{55}$ fica claro que, em grande medida, é isso que garante uma peculiar estabilidade do trabalho familiar. Quando o filho mais velho casa, ele permanece na casa paterna e trabalha como antes. Quando se dá o casamento do segundo filho, o mais velho sai de casa, mas continua trabalhando na propriedade. Este ciclo se repete até que o filho mais novo case e assuma a propriedade paterna. Em nossa opinião, é a tradição patriarcal específica, preservada no contexto de uma colônia de imigrantes, que contribui para a predominância do trabalho familiar.

\footnotetext{
${ }^{53}$ Ed. HUCITEC, 1978

${ }_{54}^{54}$ Cap. 2, passim.

${ }^{55}$ P. 51 e seguintes.
} 
Apesar disso, toma-se claro que, mesmo neste caso especial, a dependência do trabalho não-familiar é significativa. Dentre as vinte e duas unidades de produção pesquisadas durante a colheita de 1974, apenas nove não contrataram força de trabalho. Um total de trinta trabalhadores haviam sido contratados pelas restantes treze unidades, com uma média, portanto, de mais de dois por unidade. Se a isso for somado o uso generalizado da "ajuda mútua" na forma de troca de dias de serviço, a dependência do trabalho não-familiar assume proporções mais altas. Assim, fica claro que o vago conceito de "trabalho basicamente familiar" necessita de um reexame crítico. $^{56}$

\section{Conclusão}

Podemos afirmar então que, no contexto brasileiro, uma concepção errônea de pequeno produtor é comum, tanto ao nível do planejamento estatal quanto ao nível acadêmico. Esta concepção está baseada na suposta autossuficiência do trabalho familiar no processo de trabalho da pequena produção. No contexto das políticas do Estado, tal concepção está em consonância com a minimização das relações de classe capitalista no meio rural, e está de acordo com a caracterização do minifúndio como um setor produtivo, excluindo-o do papel de reservatório de força de trabalho.

No âmbito do debate acadêmico, porém, diríamos que tal conceito deriva muito da falsa polarização existente no debate clássico Leninistas $\mathrm{x}$ Populistas, que tem ainda que ser superado. No próximo capítulo, analisaremos alguns elementos deste debate, não com o objetivo de fazer qualquer "apelo à autoridade", mas, ao contrário, visando a recuperar elementos críticos excluídos da caracterização de exploração familiar feita por ambas as posições.

Ao fazê-lo, esperamos restaurar a compreensão do trabalho nãofamiliar como parte constituinte do processo de trabalho da exploração familiar. Após reanalisar o setor minifundiário do Nordeste sob este enfoque, no Capítulo Três, iremos, na Segunda Parte, demonstrar como é crucial este elemento para o entendimento da dinâmica imposta pela subordinação à estratégia modernizadora.

\footnotetext{
${ }^{56}$ Uma falha deste estudo é a pouca atenção dada ao impacto específico que o crédito e a
} assistência técnica causam ao trabalho familiar.
Capítulo dois - A exploração familiar e o trabalho assalariado. Limites do debate clássico

\section{A influência atual do debate clássico}

As polarizações do debate clássico podem ser apresentadas de forma apropriada pelos textos principais de Lênin e Chayanov, ${ }^{1}$ uma vez que foi principalmente nesta forma que o debate influenciou as discussões subsequentes.

De fato, a "Escola de Organização da Produção", da qual Chayanov era o principal porta-voz, alcançou sua proeminência muito depois da publicação de O Desenvolvimento do Capitalismo na Rússia, de Lênin, e sua oposição a este apenas tomou a forma indireta de uma luta contra os "Marxistas Agrários", no contexto do período da Nova Economia Política, na Rússia pós-revolucionária. ${ }^{2}$

Não obstante, a "Escola da Organização da Produção" foi a descendente orgânica dos pensadores populistas contra os quais Lênin dirigiu seus ataques. Esta continuidade pode ser vista na negação comum da diferenciação social - ou a dissolução do campesinato nas duas classes básicas da sociedade capitalista - como uma tendência dominante ou necessária. Enquanto os primeiros populistas defendiam principalmente uma estratégia política baseada na transição direta da estrutura comunitária do campesinato para o socialismo, Chayanov e seus coautores se limitaram à teorização da lógica não capitalista da família camponesa.

Apesar da crítica de Lênin aos populistas ter tomado a forma de uma caracterização teórica da dinâmica da agricultura camponesa no contexto russo, sua análise pode ser vista como uma crítica antecipada também à escola de Chayanov. E de sua parte, como iremos ver, Chayanov adota os mesmos métodos de análise de dados que Lênin tinha criticado no caso dos populistas.

\footnotetext{
${ }^{1}$ Lênin, V. I. The Development of Capitalism in Russia, Moscou, 1977; Chayanov. A. V. La organización de la unidad económica campesina, Buenos Aires, 1976.

2 Para uma avaliação definitiva deste debate e das origens da Escola da Organização da Produção, ver Solomon, Susan Gross. The Soviet Agrarian Debate, Boulder, Colorado, Westview Press, 1978.
} 
Assim, pode-se contrapor legitimamente os pontos de vista de Uniu e Chayanov baseando-se no fato de que foram eles que determinaram os termos da discussão corrente sobre a "exploração familiar"; mas além disso, apesar de separados por uma geração, seus respectivos textos formam de fato a mais clara expressão das diferenças teóricas básicas das análises populista e socialdemocrata sobre a questão agrária.

A recuperação da análise de Chayanov foi uma resposta às sublevações camponesas do período de descolonização após a Segunda Guerra Mundial, e representa, na prática, o ressurgimento do neopopulismo antileninista. ${ }^{3}$ Com isso, os termos do debate clássico foram novamente impostos para a problemática camponesa do Terceiro Mundo.

Embora as posições leninistas clássicas houvessem persistido, a resposta do marxismo acadêmico dominante foi a de combinar uma microanálise chayanoviana da exploração familiar com uma teoria da articulação dos modos de produção, interpretando assim a nãodiferenciação em termos de uma variante estrutural da acumulação primitiva peculiar ao Terceiro Mundo. ${ }^{4}$

Dessa forma, o arcabouço teórico disponível aos que propõem a tese da agroindústria continua a ser definido pelos termos de referência estabelecidos pelo debate clássico.

Como iremos tentar mostrar, as falsas polarizações deste debate são críticas para uma análise da problemática da subordinação da exploração familiar à agroindústria, uma vez que elas derivam de uma visão comum incorreta da estrutura interna dessa exploração familiar.

Estas limitações não foram cruciais no contexto dos debates da "articulação", uma vez que a integração do "Setor Camponês" foi vista como sendo apenas externamente ligada à acumulação industrial, e implicando somente uma simples reprodução das características tradicionais de seu processo de trabalho (superexploração e subconsumo).

${ }^{3}$ Cf. Harrison, Mark, Chayanov and the Marxists. JPS 7 (1), 1979. Também Patnak, Utsa. The Chayanovian View of the Agrarian Question and its Fundamental Fallacy, Journal of Peasant Studies, 6 (4) 1979.

${ }^{4}$ Bartra, Roger. La teoria del valor y la economia campesina: invitación a la lectura de Chayanov.
Entretanto, a característica definidora da subordinação à agroindústria é sua intervenção no próprio processo interno de trabalho da exploração familiar, e é neste contexto que a adoção de caracterizações falsas do debate clássico coloca obstáculos cruciais à análise da dinâmica do trabalho familiar integrado aos circuitos da acumulação agroindustrial.

Não tentaremos recuperar este debate clássico como um todo, mas focalizarmos especificamente o tratamento da força de trabalho não familiar, mostrando que, partindo de pontos de vista opostos, ambas as posições em confronto "constroem" uma falsa equação entre a presença de tal força de trabalho e a tendência para a dissolução da unidade de produção familiar na direção da exploração capitalista.

\section{Chayanov e a lógica não-capitalista da exploração camponesa}

A timidez das análises correntes, que, como já assinalamos, submergem o trabalho extrafamiliar sob a rubrica "trabalho basicamente familiar", contrasta violentamente com a radical exclusão feita por Chayanov de tal trabalho, exclusão esta encarada como precondição para a lógica não-capitalista da exploração familiar:

Nossa tarefa é a de analisar a organização da atividade econômica da família camponesa, uma família que não contrata mão de obra fora possui seus próprios meios de produção e, ocasionalmente, é obrigada a empregar parte de sua força de trabalho em atividades não-agrícolas. ${ }^{5}$

E novamente:

De fato, é acima de tudo a composição da família que define os limites máximo e mínimo do volume de suas atividades. A força de trabalho das unidades de economia doméstica está completamente determinada pela disponibilidade dos que, na família, estejam aptos para trabalhar.

Repetidamente ele afirma que a unidade econômica familiar deve ser vista como um conjunto indissociável, no qual o trabalho, a terra e o capital são variáveis dependentes que sofrem um contínuo processo de modificação

${ }^{5}$ Esta citação e a seguinte foram traduzidas pelo autor da versão espanhola citada acima. $O p$. cit., p. 44.

${ }^{6}$ Op. cit., p. 47 
num esforço para se estabelecer um equilíbrio entre o dispêndio de trabalho e as necessidades de consumo da unidade familiar:

o problema econômico básico de uma unidade agrícola é a correta e solidária organização do trabalho anual, estimulados pela necessidade básica de cobrir o orçamento familiar anual e pelo desejo natural de poupar ou investir capital se as condições econômicas de trabalho o permitirem. ${ }^{7}$

Desta maneira, no âmbito da exploração familiar, o trabalho não tem um preço fixo por unidade, uma vez que seu valor só pode ser determinado em relação ao resultado do balanço global trabalho-consumo, o qual está submetido a variações contínuas em função dos preços de mercado, fertilidade do solo, tamanho das explorações etc. ${ }^{8}$

Chayanov toma isto claro quando ele contrasta o papel do trabalho na unidade familiar e na exploração capitalista:

Podemos estabelecer um cálculo econômico para a exploração capitalista através da seguinte fórmula:

$$
G I-E M+S-N P
$$

onde $G I=$ renda bruta; $E M=$ gasto em maquinaria e matérias-primas; $S=$ salários e $N P=$ lucro líquido.

Todos os elementos desta fórmula são quantidades que podem facilmente ser expressos na mesma unidade básica - rublos - e um simples cálculo aritmético permite determinar o lucro líquido com precisão. Se o resultado for maior que zero pode-se dizer que a exploração econômica está operando sem perda... Esta fórmula pode ser aplicada para a exploração econômica familiar? É claro que a resposta deve ser negativa. Ela é aplicável no caso da exploração capitalista pois todos os seus elementos podem ser expressos na

${ }^{8}$ Deve-se salientar que a aplicabilidade da teoria de Chayanov não foi vista como limitada às condições da economia natural. É fundamental para seu argumento a afirmação de que é a evolução da oferta de trabalho familiar que determina relações com o mercado em termos de escolha de produtos, e não a escolha de produtos que determina as relações com o mercado via mecanismos de preço. Cf. também Harrison M. "[Chayanov] desenvolveu uma teoria sistemática da economia camponesa baseado na estrutura especifica da economia camponesa - a utilização do trabalho familiar não-assalariado na exploração familiar. Esta teoria era independente da existência ou não da produção de mercadorias". Ver The Peasant Mode of Production in the Work of A. V. Chayanov.
}

mesma unidade de valor. Já na unidade camponesa, só se pode expressar a renda bruta e o gasto em insumos em termos de unidades objetivas de valor. Sem salários, a unidade camponesa somente pode expressar seu consumo de trabalho em termos de unidades físicas. ${ }^{9}$

Assim, a exclusão do trabalho assalariado não é simplesmente uma questão empírica, mas uma das precondições, e talvez a mais importante, para a dinâmica peculiar da produção camponesa da forma como Chayanov a vê:

Creio que, desta maneira, consegui demonstrar que a unidade econômica familiar, dada a ausência da categoria salário, difere, em seu comportamento econômico, da unidade econômica baseada no trabalho assalariado, tanto em termos de seus cálculos quanto na motivação para o trabalho. Analogamente, a circulação de capital ocorre de uma forma diferente da modalidade capitalista que foi tão brilhantemente analisada por Marx no volume II de $O$ Capital. ${ }^{10}$

\section{E novamente:}

Se contrapusemos, e continuamos a fazê-lo com particular insistência, a unidade familiar à unidade capitalista, fazemo-lo do ponto de vista de sua organização e produção: a unidade familiar em contraste com a baseada no trabalho assalariado. Neste caso, estamos nos confrontando com duas máquinas econômicas completamente diferentes, que reagem de diferentes maneiras diante dos mesmos fatores econômicos. ${ }^{11}$

Assim, evidencia-se que, a despeito de defender uma posição empírica diametralmente oposta, Chayanov atribui o mesmo significado que Lênin ao trabalho contratado pela unidade camponesa. Ao comentar o predomínio do trabalho assalariado nas unidades de exploração familiar alemãs, ele as descreve como "semicapitalistas". É também por essa razão que ele limita a aplicabilidade de sua teoria àqueles países onde o trabalho contratado não é uma característica da unidade de exploração familiar. ${ }^{12}$

Esta polarização radical que Chayanov estabelece deriva de que a unidade familiar dependente do trabalho contratado terá custos unitários

\footnotetext{
${ }^{9}$ Op. cit.

${ }^{10}$ Op. cit., p. 260

${ }^{11}$ Op. cit., p. 260.

${ }^{12}$ Op. cit., p. 124.
} 
fixos, incompatíveis com a flexibilidade do trabalho (que Kautsky chamaria de capacidade do camponês para a autoexploração) requerida para estabelecer o equilíbrio consumo-trabalho. Uma vez que se contrata trabalho, uma lógica capitalista penetra na unidade familiar, que deve agora basear-se em retornos compatíveis com esses custos unitários fixos. ${ }^{13}$

Uma solitária referência no fim do texto de Chayanov estabelece uma distinção entre "trabalho contratado para auxiliar o trabalho familiar" e "trabalho contratado para produzir lucro" (p. 303). Mas esta distinção não é teorizada em nenhum lugar e, de fato, introduz uma distinção puramente subjetiva, que entra em contradição com sua polarização dos dois tipos de trabalho - um que é expresso em custos unitários fixos e se apresenta, desta forma, como uma variável independente, e o trabalho familiar, cujo valor só possibilita objetividade em termos do balanço consumo-trabalho.

É por essa razão que Chayanov esforça-se em minimizar o uso de trabalho extrafamiliar entre os camponeses russos, já que é a inexistência do trabalho contratado que, a seu ver, confere a relevância empírica à sua teoria. Ele afirma que "aqui na Rússia, $90 \%$ de todas as unidades camponesas são exploradas puramente na base do trabalho familiar". Entretanto, no texto, há poucos dados estatísticos para dar suporte a esta posição; os dados que ele compila referem-se a regiões isoladas, e quase certamente só a trabalho permanente. ${ }^{14}$

\footnotetext{
${ }^{13}$ Cf. também Harrison, M. “A concepção unitária da economia familiar significa também abstrair a economia nacional e analisar a exploração familiar como um empreendimento imune à categoria salário, ao trabalho assalariado e a mercados de trabalho... Pois somente na ausência de relações sociais tanto internas quanto externas foi possível gerar um dos mais celebrados conceitos da tradição chayanoviana: o de que a determinação da quantidade de trabalho empregada na 'economia camponesa' resultava não da exploração (alguns por outros) mas da autoexploração - a preferência revelada da família como um todo. Esta foi a base da construção de Chayanov do utilitário balanço trabalho-consumo familiar" (p. 89 in Chayanov and the Marxists).

${ }^{14}$ Na página 304 deste estudo, Chayanov se refere aos dados coletados de vários "vezds" (microrregiões) no distrito de Penz, dando um valor médio de 3,5\%; dados de orçamento para a área de Starabolsk, que alcançavam a média de 9,9\%; e, finalmente, dados de um único "vezd" que forneciam o valor próximo de 7\%. Os dados de Lênin são incomparavelmente mais detalhados. Sobre a questão do trabalho permanente, cf. nossa discussão sobre Lênin a seguir, neste Capítulo.
}

\section{Lênin e a base empírica da diferenciação social}

Infelizmente, os dados estatísticos usados por Lênin em Development of Capitalism in Russia para discutir a questão da contratação de trabalho não coincidem com os de Chayanov, não sendo, portanto, possível uma comparação direta. No entanto, suas fontes gerais são as mesmas - os relatórios dos zemstvos e os dados de orçamentos domésticos e a crítica de Lênin à organização destes dados se aplica igualmente a Chayanov, que adota os critérios interpretativos estabelecidos pelos narodniks, majoritários entre os apurados destes relatórios.

Um elemento chave na tentativa feita por Chayanov para demonstrar o equilíbrio trabalho-consumo foi o dado estatístico mostrando uma correlação entre tamanho familiar e área cultivada. Chayanov argumentou que a Rússia apresentava condições privilegiadas para a plena expressão desta tendência, como um resultado das peculiaridades do sistema de terras comunais. Após a Reforma, na Rússia, foi imposta uma taxa comunal por aldeia, e isto levou a uma redistribuição periódica da terra comunitária em função da capacidade da família para cultivá-la. Teoricamente, portanto, o tamanho da terra refletiria paralelamente ao ciclo da fann1ia, revelando assim mais um processo demográfico do que um processo social de diferenciação. ${ }^{15}$

Entretanto, o que Lênin assinala é que se ponderações econômicas são aplicadas aos dados (número de cavalos, área de terra alugada, arrendada ou comprada, trabalho assalariado etc.), há uma permanente correlação entre tamanho familiar e bem-estar econômico, e que as maiores famílias são precisamente aquelas que contratam a mais alta proporção de trabalho assalariado:

Notemos que quando se classificam as famílias de acordo com seu poder econômico ou com o tamanho da unidade produtiva, sempre encontramos as maiores famílias no estrato dos mais bem situados do campesinato. Este fenômeno aponta para a conexão entre a burguesia camponesa e as grandes famílias que recebem um maior número de lotes; em parte isto mostra o oposto: indica menor disposição do campesinato mais bem situado para dividir a terra. Não se deve,

\footnotetext{
${ }^{15}$ Para um bom sumário da questão das terras comunais, cf. Archetti, Eduardo P. La comuna campesina en Rusia. In Chayanov, Op. cit.
} 
entretanto, exagerar a importância das grandes famílias entre os camponeses mais bem situados, que, como nossos dados mostram, lançam mão em mais alto grau do emprego de trabalho contratado. A 'cooperação familiar' da qual nossos narodniks falam tão afetuosamente é então a base da cooperação capitalista (p. 95.)

Ademais, Lênin mostra que o lote já não pode mais ser considerado como o ponto central de referência para determinar a posição do campesinato, como os narodniks e Chayanov seguindo seus passos tentaram argumentar. Ao definir em princípio o tamanho da terra em termos do tamanho do lote, Chayanov despreza o fato de que arrendamento, aluguel e compra de terra tinham reduzido o lote a um elemento subordinado na produção global "camponesa". Os dados de Lênin mostram que $80 \%$ dos camponeses do estrato inferior, constituído por $50 \%$ das famílias, alugaram uma parte de seus lotes de terra a outrem, enquanto somente $10 \%$ arrendavam terras alheias e outros $10 \%$ compraram terra. Do estrato superior, constituído de 20\% das famílias, apenas 6\% alugavam terras (a outrem), enquanto $60 \%$ arrendavam de outros e $80 \%$ compravam terra. ${ }^{16}$

Ao organizar os dados em bases demográficas (de acordo com o tamanho familiar) ao invés de empregar critérios econômicos, os narodniks e Chayanov, por sua vez, dissimulavam um processo de diferenciação que estava transformando o campesinato. Com uma bateria de estatísticas retrabalhadas, Lênin não deixa dúvidas quanto à realidade deste processo e quanto à existência de divisões de classe, com a formação de um estrato de proletários rurais em confronto com um campesinato bem situado apoiado amplamente no trabalho assalariado.

Entretanto, sérias dúvidas podem ser levantadas com respeito às dimensões deste processo. Com o objetivo de estabelecer as divisões de classe no interior do campesinato, Lênin, na reestruturação dos dados, contrasta as características dominantes do estrato superior, constituído por $20 \%$ das famílias, com aquelas do estrato inferior, onde se localizam 50\% das famílias. Este método é legítimo se se visa a estabelecer as linhas gerais da divisão de classes no interior do campesinato, mas toma-se questionável quando se afirma que estas percentagens representam estas classes, i.é., que $50 \%$ dos camponeses são proletários rurais e $20 \%$ compõem a burguesia.

\footnotetext{
${ }^{16}$ Op. cit., p.132-5.
}

Entretanto, foi exatamente isto o que Lênin, instigado pela sua luta contra os narodniks, tentou provar.

Lênin usa como base os resultados do censo militar de cavalos argumentando que "em toda a Rússia, a distribuição de cavalos de tração entre o campesinato é muito próxima ao grau 'médio' de diferenciação que delineamos em nosso gráfico". De acordo com estes dados, o número de famílias camponesas sem cavalos ou com apenas um representa 53\% da população camponesa. Usando esta classificação, ele então analisa as estatísticas dos zemstvos sobre orçamentos com relação a itens tais como a distribuição de gastos entre consumo pessoal e gastos produtivos, a renda líquida, a importância da renda obtida fora da unidade de produção etc., visando a provar que, de fato, estes $53 \%$ representam as dimensões reais do proletariado rural.

Entretanto, enquanto em termos de renda líquida as famílias sem cavalos equivalem grosseiramente às com apenas um cavalo, os outros indicadores estabelecem uma pronunciada diferenciação neste estrato. Enquanto que para as famílias sem cavalos a renda de atividades desenvolvidas fora da unidade de produção (i.é., assalariamento) atinge uma proporção de $51 \%$ da renda total, este dado é reduzido para $27 \%$ no caso das famílias com apenas um cavalo. ${ }^{17}$ De forma semelhante, se comparamos gastos produtivos (em oposição a gastos em consumo pessoal), encontraremos que aqueles se resumem a $13,87 \%$ no caso das famílias sem cavalos, e chegam a $33,46 \%$ para aquelas com um cavalo. Este valor é comparável ao valor dos gastos produtivos para famílias com dois cavalos, e é apenas ligeiramente inferior aos das famílias com três ou quatro cavalos. ${ }^{18}$

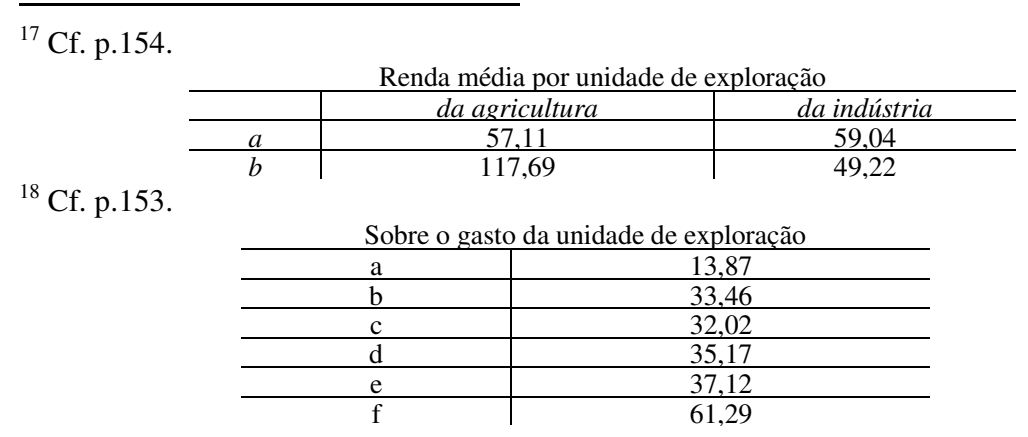


A análise deste dado, portanto, sugeria que as famílias com um cavalo, que representam $25 \%$ do total da população camponesa, ao invés de ser definidas essencialmente como de trabalhadores rurais, devam ser consideradas principalmente como famílias camponesas. Tal interpretação é reforçada se considerarmos os próprios dados de Lênin sobre trabalho assalariado empregado pela metade mais pobre das famílias. Estes dados mostram que, em média, mais de $8 \%$ dessas explorações empregam trabalho assalariado, e que em três das sete províncias das quais Lênin obtém estes dados, esta média alcança 15\%. Se assumirmos que as explorações que empregam trabalho assalariado correspondem às famílias com um cavalo - as quais representam mais da metade deste grupo - os dados para trabalho contratado se tornarão ainda mais significativos, alcançando uma média geral de $16 \% .^{19}$ Isto poderia indicar, desta forma, que o proletariado rural, ao invés de ser constituído por mais de $50 \%$ das famílias camponesas, estaria situado entre $25 \%$ e $30 \%$.

Restrições semelhantes poderiam ser feitas à categoria superior de Lênin - os 20\% da "burguesia rural". Se olharmos novamente para os dados oriundos do censo de cavalos, este valor é obtido pelo agrupamento de todas as unidades com três ou mais cavalos. ${ }^{20}$ Em outra parte, entretanto, Lênin argumenta que o camponês médio deveria ser definido como aquele que possui de 2 a 3 cavalos, uma vez que 4 cavalos são necessários para formar um par de juntas. ${ }^{21} \mathrm{Se}$, desta forma, usarmos seu próprio critério e excluirmos aquelas unidades com somente 3 cavalos da categoria superior (a da "burguesia camponesa"), esta última tornar-se-ia uma cifra mais modesta: $11,4 \% .^{22}$ Tal valor se ajustaria melhor aos próprios dados de Lênin sobre assalariamento do trabalho, o qual ocorre em apenas $63 \%$ das unidades de produção dentre as $20 \%$ superior. $^{23}$

${ }^{19}$ Cf. Lênin, Op. cit., p. 135-5.

${ }^{20}$ Cf. Lênin, Op. cit., p. 144.

${ }^{21}$ Cf. Lênin, Op. cit., p. 80: "aqui o número de animais de tração atinge 3,2 por domicílio, enquanto um conjunto completo exige 4 deles. Por isso, a posição das explorações camponesas médias é instável, e para trabalhar sua terra eles têm de recorrer a associações com outros".

${ }^{22}$ Op. cit., p. 144

${ }^{23}$ Op. cit., p. 132-3.
Embora reconheçamos a correção da ênfase de Lênin sobre a penetração capitalista no campesinato e a existência de contradições de classe, julgamos, com base em seus próprios dados, que as dimensões quantitativas deste desenvolvimento foram grandemente exageradas.

O camponês médio, longe de representar uma minoria de $30 \%$ deveria ser considerado como mais de $60 \%$ da população total de camponeses.

\section{Lênin, o camponês médio e o trabalho assalariado}

Mas esta subestimação da proporção representada pelo campesinato médio tem suas raízes numa caracterização apriorística da economia camponesa (entendida como uma unidade de produção baseada na família) como sendo essencialmente um fenômeno de transição no contexto da expansão capitalista.

$\mathrm{Na}$ conclusão do segundo capítulo sobre a "Diferenciação do Campesinato", Lênin sintetiza sua visão sobre o médio campesinato da seguinte maneira:

6) $\mathrm{O}$ elo intermediário entre estes tipos de campesinato posteriores à Reforma é constituído pelos camponeses médios que se distinguem pelo menor desenvolvimento da economia mercantil. O trabalho agrícola por conta própria desta categoria de camponeses cobre sua manutenção talvez somente nos melhores anos e em condições especialmente favoráveis, e por isso ele se encontra em uma situação de extrema instabilidade. Na maioria dos casos, o camponês médio não pode avançar sem contrair dívidas a serem pagas em trabalho etc., sem buscar rendas "complementares" que, em parte, consistem também na renda da força de trabalho etc. Cada má colheita empurra massas de camponeses médios para as fileiras do proletariado. Por suas relações sociais, este grupo oscila entre o superior, que o atrai, mas no qual somente consegue entrar uma pequena minoria de afortunados, e o inferior, ao qual o impele toda a marcha da evolução social. Vimos como a burguesia camponesa desloca não somente o grupo inferior dos camponeses, mas também o médio. Opera-se pois uma limpeza dos membros médios e um reforço dos extremos: "descampesinação", fenômeno específico da economia capitalista. (p. 184.) 
O que é interessante nesta passagem é que ela não encontra substância no texto. Se vale para algum grupo, é mais apropriada para as famílias com um cavalo, que reclassificamos como o estrato mais baixo entre os camponeses médios.

A chave para a tese de Lênin é que o campesinato médio "se distingue pelo menor desenvolvimento da produção mercantil". Isto é combinado com a suposição puramente teórica de que uma economia camponesa desse tipo, sob o impacto do desenvolvimento capitalista, deve se dissolver em trabalho assalariado ou ser transformada em exploração capitalista:

O velho campesinato não está apenas se 'diferenciando'; ele está sendo totalmente dissolvido, está deixando de existir, deslocado por tipos de população rural totalmente novos, por tipos que constituem a base da sociedade na qual dominam a economia mercantil e a produção capitalista. Estes tipos são a burguesia rural (pequena burguesia, principalmente) e o proletariado rural, a classe dos produtores de mercadorias na agricultura e a classe dos trabalhadores agrícolas assalariados. (p. 177.)

Porém, se olharmos os dados que Lênin emprega, descobriremos que o campesinato médio (categorias $c$ e $d$ nos quadros a seguir) tem um nível significativo de gastos produtivos em sua exploração:

Tabela 1 - Sobre gastos produtivos na exploração

\begin{tabular}{c|c|c}
\hline Grupos & em rublos & $\%$ \\
\hline a & 15,12 & 13,87 \\
\hline b & 58,32 & 33,46 \\
\hline c & 121,42 & 32,02 \\
\hline d & 222,39 & 35,17 \\
\hline e & 347,76 & 37,12 \\
\hline f & 976,84 & 61,29 \\
\hline
\end{tabular}

Lênin. Op. cit., p. 153

De forma semelhante, para este campesinato médio a renda em dinheiro proveniente da agricultura, indicando produção comercial, é comparável com a dos grupos que Lênin classificaria como o campesinato "remediado":
Tabela 2 - Relação entre renda em dinheiro e total de renda da agricultura (em\%)

\begin{tabular}{c|c}
\hline Grupos & $\%$ \\
\hline $\mathrm{a}$ & 9,68 \\
\hline $\mathrm{b}$ & 18,55 \\
\hline $\mathrm{c}$ & 18,93 \\
\hline $\mathrm{d}$ & 18,45 \\
\hline $\mathrm{e}$ & 19,17 \\
\hline $\mathrm{f}$ & 6,02 \\
\hline
\end{tabular}

Lênin. Op. cit., p. 164

$\mathrm{E}$, finalmente, o gasto em dinheiro dos camponeses médios em itens de consumo doméstico equivale aos de outros grupos:

\begin{tabular}{c|c|c}
\multicolumn{3}{c}{ Tabela 3 - Consumo per capita, em rublos, de ambos os sexos } \\
\hline Grupos & $\begin{array}{c}\text { Total em alimentação e outros } \\
\text { gastos pessoais }\end{array}$ & Parte gasta em dinheiro \\
\hline a & 19,21 & 9,59 \\
\hline b & 19,86 & 7,84 \\
\hline c & 27,41 & 9,31 \\
\hline d & 27,71 & 8,51 \\
\hline e & 36,73 & 13,69 \\
\hline f & 33,15 & 11,73 \\
\hline
\end{tabular}

Lênin. Op. cit., p. 167.

O camponês médio, desta forma, está bastante integrado à produção mercantil. Isto se evidencia mais na questão do trabalho assalariado. Já mostramos que o emprego de mão de obra assalariada é significativo mesmo no caso das famílias com um cavalo. O próprio Lênin não fornece dados não agregados sobre os $30 \%$ que ele define como campesinato médio, mas os dados sobre trabalho assalariado para a Província de Perm são particularmente significativos.

Ao se referir a estes dados, Lênin assinala que eles são uma fonte particularmente valiosa, uma vez que "foram adicionados dados relativos à contratação de diaristas” (p. 109). Isto sugeriria, portanto, que as estatísticas gerais empregadas por Lênin e que usamos como base de nossa crítica referem-se apenas ao trabalhador permanente e, assim, subestimam completamente a significância do trabalho assalariado no contexto da produção familiar. 
Em termos de área cultivada, Lênin define o estrato médio como aquele que tem entre 10 e 25 dessiatinas cultivadas. ${ }^{24}$ Então, no quadro a seguir, os dados para o grupo de 10-20 deveriam ser aumentados para se obter uma imagem correta:

Tabela 4 - Percentagem de explorações que empregam assalariados

\begin{tabular}{c|c|c|c|c}
\hline \multirow{2}{*}{ Área cultivada } & \multicolumn{4}{|c}{ Força de trabalho } \\
\cline { 2 - 5 } & Sazonal & $\begin{array}{c}\text { Para ceifa de } \\
\text { feno }\end{array}$ & $\begin{array}{c}\text { Para colheita de } \\
\text { cereais }\end{array}$ & Para trilhar \\
\hline $0-5$ & 0,7 & 5,1 & 4,7 & 9,2 \\
\hline $5-10$ & 4,2 & 14,3 & 20,1 & 22,3 \\
\hline $10-20$ & 17,7 & 27,2 & 43,9 & 25,9 \\
\hline $20-50$ & 50,0 & 47,9 & 69,6 & 33,7 \\
\hline acima 50 & 83,1 & 64,5 & 87,2 & 44,7 \\
\hline
\end{tabular}

Provavelmente, portanto, cerca de $50 \%$ do grupo médio emprega diaristas durante o ciclo agrícola, e algo como $20 \%$ emprega trabalhadores sazonais. Assim, a força de trabalho assalariado é um componente estrutural da exploração familiar, que compreende a maioria das famílias camponesas.

Os comentários de Lênin a este respeito são de particular interesse. Ele conclui corajosamente que o assalariamento de diaristas "é um indicador particularmente característico da pequena burguesia". O camponês médio é incluído no "grupo bem-sucedido" de forma a permitir a conclusão geral:

A maioria das famílias camponesas bem-sucedidas empregam força de trabalho assalariada de uma forma ou outra. A formação de um corpo regular de trabalhadores rurais e diaristas é uma condição essencial para a existência do camponês bem-sucedido. médio. $^{25}$

Entretanto, isto também é verdadeiro para o caso do camponês

\footnotetext{
24 "Finalmente, examinemos a posição do grupo médio (que cultiva de 10 a 25 dessiatinas por domicílio)". Lênin, $O p$. cit., p. 80 ( 1 dessiatina $=1,1$ ha).

${ }^{25}$ Cf. comentários de Harrison sobre os dados do distrito de Starobel'sk: "Além disso, há uma substancial área cinzenta, particularmente no intervalo médio, onde os produtores tanto contratavam quanto vendiam força de trabalho no curso do mesmo ano. Desta forma, os dados não revelaram nenhuma ambígua barreira de classe na aldeia ('village'); além do mais, revelam algum elemento marginal de verdade na ideia de que trabalhar em outra unidade de
}

Na medida em que Lênin reconhece o uso da força de trabalho assalariada nos mais baixos grupos, ele tenta estabelecer uma nítida distinção entre diaristas, e trabalhadores permanentes, vendo os primeiros como um fenômeno essencialmente de transição:

Finalmente, é muito interessante sublinhar que a relação entre o número de explorações que contratam diaristas e o das que contratam trabalhadores regulares decresce dos grupos camponeses inferiores para os superiores. Nos grupos inferiores, o número de explorações que contratam diaristas supera sempre em muitas vezes o das que contratam trabalhadores regulares. Nos grupos superiores, ao contrário, o número de explorações que contratam trabalhadores regulares é, às vezes, superior inclusive ao das explorações que contratam diaristas. (p. 110.)

Entretanto, uma tal conclusão não pode ser tirada destes dados, uma vez que a proporção numérica entre diaristas e trabalhadores permanentes não é fornecida. Nos dados que Lênin fornece na página seguinte, onde os camponeses médios são convenientemente reunidos com camponeses "bem-sucedidos", a relação entre trabalhadores sazonais e diaristas é particularmente notável:

\begin{tabular}{c|c|c|c}
\multicolumn{4}{c}{ Tabela 5 - Trabalhadores assalariados } \\
\hline \multirow{2}{*}{ Grupos } & Sazonais & Diaristas & \multirow{2}{*}{ Famílias } \\
\cline { 2 - 3 } & 218 & 28.015 & 12.851 \\
\hline Com 1 cavalo & 1.481 & 106.318 & 16.484 \\
\hline $\begin{array}{c}\text { Com vários } \\
\text { cavalos }\end{array}$ & \multicolumn{2}{l}{} \\
\hline \multicolumn{2}{c}{ Lênin. Op. cit., p. 111. }
\end{tabular}

A afirmação feita por Lênin de que o trabalho assalariado permanente viria a predominar nos grupos superiores é mais o resultado de uma teorização apriorística do que uma reflexão sobre uma tendência empírica discernível. Sua conclusão final não é muito mais que uma profissão de fé:

Este fato indica claramente a formação de explorações que empregam trabalhadores nos grupos superiores do campesinato baseados no emprego regular de trabalho assalariado; 0 assalariamento se distribui mais uniformemente pelas estações do

produção era simplesmente um favor mútuo a ser retribuído com presteza”. Cf. Chayanov and the Economics of the Russian Peasantry, p. 409. 
ano, o que permite dispensar a contratação mais dispendiosa e problemática de diaristas. (p. 110.)

A repetida equação feita por Lênin entre o assalariamento da força de trabalho e o desenvolvimento da exploração capitalista deriva de sua luta contra os narodniks, os quais afirmavam que:

a contratação de diaristas e de trabalhadores por pequenos períodos para a colheita de cereais, ceifa de feno etc., é um fenômeno demasiadamente generalizado, não podendo servir como critério para a caracterização do vigor ou fraqueza de uma exploração (citando um texto do "Sr. Kharizomanov", p. 97). ${ }^{26}$

Levando em conta que tal posição foi formulada como forma de negar qualquer processo de proletarização, a polêmica leninista está corretamente situada. Mas em sua determinação de "esmagar" a posição dos narodniks, Lênin se recusou a reconhecer o caráter híbrido da "típica" exploração baseada na força de trabalho familiar, onde o assalariamento é um fenômeno característico.

Para Lênin, uma vez que a "economia natural" se abra para a produção mercantil, sua tendência é a dissolução nas fileiras do proletariado rural, com uma pequena fração se transformando em produtos capitalistas. Entretanto, os dados indicam um poder de sobrevivência muito maior da pequena produção familiar mercantil. Em parte, isto deve ser explicado pela própria análise leninista da natureza da burguesia "camponesa". Lênin sustenta, contra os narodniks, que o "mujique empreendedor" e o kulak, são uma única e mesma pessoa.

Como já vimos acima, mesmo entre o campesinato bem-situado, o nível de emprego de assalariados permanentes não excede 60\%. Também é claro que na maioria dos casos a família continua a trabalhar ao lado do trabalhador assalariado. Mesmo no estrato superior do campesinato, uma exploração claramente capitalista é um fenômeno muito reduzido. Em geral, a maior parte da renda dos camponeses bem-situados deriva de atividades

${ }^{26}$ Embora Chayanov seja o representante teórico da tradição narodnik, ao erigir seu modelo ele exclui um importante elemento empírico do conflito leninista/populista, i.é, o "difundido fenômeno" do trabalho extrafamiliar. Na ausência de uma teorização deste fenômeno pelos narodniks, Lênin foi capaz de caracterizá-lo em todos os seus aspectos como uma expressão de diferenciação. não-agrícolas, entre as quais predominariam atividades de capitalista mercantil:

Tabela 6 - Renda média por exploração

\begin{tabular}{c|c|c}
\hline $\begin{array}{c}\text { Categoria por tamanho de } \\
\text { propriedades }\end{array}$ & $\begin{array}{c}\text { Proveniente da } \\
\text { agricultura }\end{array}$ & $\begin{array}{c}\text { Provenientes das } \\
\text { indústrias }\end{array}$ \\
\hline $\mathrm{a}$ & 57,11 & 59,04 \\
\hline $\mathrm{b}$ & 127,69 & 49,22 \\
\hline $\mathrm{c}$ & 287,40 & 108,21 \\
\hline $\mathrm{d}$ & 496,52 & 146,67 \\
\hline $\mathrm{e}$ & 698,06 & 247,60 \\
\hline $\mathrm{f}$ & 698,36 & 975,20 \\
\hline
\end{tabular}

Lênin. Op. cit., p. 154.

Nota: A letra $f$ representa a burguesia camponesa, de acordo com nossa reclassificação.

O capital mercantil, em oposição à exploração capitalista, não obtém seu excedente do trabalhador rural, mas precisamente dos produtores camponeses. O camponês bem-situado, agindo como capitalista mercantil, cria as condições para a sobrevivência dos camponeses (em termos de adiantamentos de crédito) mas, ao mesmo tempo, impede sua transformação num setor de exploração capitalista, através da apropriação de grande parte de seu excedente sob a forma de juros. Isto explicaria a "estabilidade" do camponês médio e seu peso no contexto da agricultura russa. ${ }^{27}$

\section{A teoria de Chayanov e a questão do trabalho assalariado}

Podemos dizer, desta maneira, que os dados de Lênin estabeleceram decisivamente a importância do trabalho assalariado no seio do campesinato russo. Entretanto, como o trabalho assalariado era para ele o critério-chave para o desenvolvimento da exploração agrícola capitalista, Lênin interpretou de forma sistematicamente incorreta as estatísticas, concluindo que a presença deste tipo de trabalho "era um indicador particularmente característico da existência de uma burguesia rural" (p. 109, Op. cit.), que marcava a dissolução da economia camponesa.

\footnotetext{
${ }^{27}$ A análise no contexto brasileiro poderia sugerir, entretanto, que tal estabilidade é para ser entendida nos termos de uma espiral declinante a longo prazo. Cf.. Borges, Maurício. Um estudo comparativo sobre as formas de organização da produção de arroz no Brasil (19501970). Campinas, 1977 (mimeo).
} 
Partindo de um ponto de vista inteiramente oposto, no entanto atribuindo a mesma importância à questão do trabalho assalariado, Chayanov afirmou que a inexistência deste fenômeno foi o fator central que assinalou a predominância da economia camponesa com sua dinâmica especificamente não-capitalista.

Com base em nossa crítica aos dados de Lênin, é possível reafirmar a predominância da economia camponesa como defendida por Chayanov, porém marcada por uma dependência significativa do assalariamento e, em particular, do assalariamento por dia.

Agora, vamos verificar se o rigor com o qual Chayanov excluiu a categoria do trabalho assalariado é garantido nos termos de sua própria teoria, isto é, se a dinâmica não-capitalista, tal como ele a analisa, é incompatível com a presença do assalariamento.

Uma possível solução à questão pode ser encontrada no capítulo que Chayanov dedica à lógica da absorção do capital pela unidade camponesa. Ao tentar resolver esta questão, Chayanov assinala que o trabalho familiar é submetido a restrições específicas, e que seus limites são determinados pelo período de seu gasto máximo durante o ciclo agrícola. ${ }^{28}$

A unidade econômica camponesa normalmente sofre muito com as irregularidades temporais da organização de sua força de trabalho, como uma consequência das características específicas de muitos tipos de cultivos. O período de colheita, com sua máxima utilização de trabalho, determina assim a área total que pode ser cultivada. Se o trigo, uma vez que maduro, pode durar, digamos, uma semana e meia antes que caia, é claro que a área a ser semeada será igual àquela que pode ser colhida numa semana e meia (Chayanov, Op. cit., p. 221).

É por esta razão que Chayanov argumenta que os camponeses comprarão colheitadeiras e outros equipamentos de capital, mesmo que estes, dada a reduzida área de seus lotes, ${ }^{29}$ possam não se justificar em termos de rentabilidade capitalista. Para a família camponesa, o

\footnotetext{
${ }^{28}$ Cf. também a apropriada formulação de Marx a respeito deste mesmo problema: "Sempre há trabalhadores agrícolas demais para as tarefas comuns e sempre muitos poucos para as necessidades excepcionais ou temporárias do cultivo do solo" (O Capital, v. III, p. 693).

${ }^{29}$ Não iremos considerar aqui a questão de que, pelo uso das "médias narodniks", Chayanov possa ter exagerado a pequenez das áreas exploradas pelos camponeses que tinham ceifadeiras.
}

equipamento (bem de capital) não é um meio para economizar trabalho, mas, pelo contrário, permite seu uso mais extensivo ao longo do restante do ciclo agrícola. Isto possibilita o cultivo de uma área muito maior e, desta maneira, leva a um significativo incremento absoluto da renda bruta, que não poderia ser obtido de outro modo.

Desta forma, a maquinaria incorporada encontra sua lógica nas condições que cria para o aumento da autoexploração da família camponesa:

Tome-se o exemplo de uma família com duas pessoas em condições de trabalhar, e imagine-se que o período possível de colheita seja de 10 dias: com isso, a área máxima que uma família pode colher com seus próprios recursos seria de 4,65 dessiatinas. Como uma dessiatina requer um total de 21,4 dias de trabalho e gera uma renda bruta de 29 rublos e 10 copeques, excluindo as sementes, a família que explora este lote poderia trabalhar 94,8 dias (47,4 dias por homem-ano), aumentando seus meios de subsistência em 139,3 rublos.

Entretanto, com uma colheitadeira mecânica, a mesma família pode mais do que dobrar a área cultivada, e ao plantar digamos 10 dessiatinas, poderia empregar sua força de trabalho por cerca de 200 dias por ano, gerando 291,6 rublos de renda bruta. Se deduzirmos 30 rublos para amortização e reparos, ficaremos com 261,6 rublos, que são superiores em 100 rublos ao que poderia ser obtido somente pelo trabalho normal. Um tal incremento considerável nos meios de subsistência é um ganho enorme para a unidade doméstica, mesmo que do ponto de vista do puro cálculo econômico não seja rentável usar uma colheitadeira mecânica somente para 10 dessiatinas (Chayanov, Op. cit., p. 222).

Embora Chayanov limite a aplicação desta lógica à absorção do equipamento, não há razão para que o emprego do trabalho não possa ser incluído nesta mesma categoria, neste caso sendo comparável ao aluguel da maquinaria. Como vimos, ao discutir os dados dos zemstvos, é o diarista que predomina na unidade camponesa, sendo contratado para cobrir os períodos críticos do ciclo agrícola. Sua lógica não dependeria do critério capitalista de rentabilidade por unidade de trabalho empregado: a unidade camponesa contrataria mão de obra na medida em que isto permitisse um maior uso do trabalho familiar durante o resto do ciclo agrícola, possibilitando assim um incremento significativo na renda bruta ao fim 
deste ciclo. Interpretando neste sentido, o uso do trabalho assalariado não necessita invalidar a lógica não-capitalista peculiar à unidade de produção familiar, tal como concebida por Chayanov.

\section{Chayanov, a agroindústria e a lógica não-capitalista do camponês}

Se adicionarmos às projeções de Chayanov descritas acima, uma tendência à concentração capitalista mais em termos verticais do que horizontais, é possível que tenhamos nele a base teórica para uma análise da nova subordinação da produção familiar à agroindústria.

De fato, como a longa citação a seguir revela, Chayanov conseguiu uma fundamentada avaliação - nítida e muito moderna - da transformação efetivada pela subordinação da produção agrícola ao capital industrial, comercial e financeiro:

Os mecanismos descritos, com suas antenas de ramificações, penetram fundo nas unidades econômicas camponesas, e, embora as deixem livres no que tange à produção, dominam-nas totalmente ao nível econômico. Renda, nível de bem-estar e o poder para constituir capital de algumas destas unidades de produção de linho em Gzhatsk começam a depender, em grau extremamente alto, das relações puramente capitalistas com a Europa Ocidental e, às vezes, dos financiamentos que os bancos norte-americanos oferecem aos moinhos de Belfast.

A máquina comercial, interessada em estabelecer uma qualidade unificada para os produtos que centraliza, também começa a interferir diretamente na organização da produção. Ela dita as condições técnicas, fornece as sementes e fertilizantes, determina os sistemas de rotação e converte seus fornecedores em executores técnicos de seus objetivos e de seu plano econômico. Um exemplo característico deste tipo de intervenção foi o plantio de beterraba açucareira em terras de camponeses, com base em um contrato com as fábricas de açúcar. Tendo regulado os mecanismos de renda e criado a base para o mercado capitalista de matérias-primas, iniciou a penetração ao nível da própria produção no interior do país. Isolou diferentes setores da atividade econômica camponesa, particularmente aqueles voltados ao processamento primário de matérias-primas agrícolas e, em geral, aqueles ligados a processamentos mecânicos. Exemplos óbvios disto são os debulhadores a vapor ambulantes no sul da Rússia, pequenos moinhos na Sibéria ao fim do século XIX, e as fábricas de processamento do linho na França, além das nossas próprias regiões produtoras de linho.

Se a isto adicionarmos a ampla expansão do crédito hipotecário, o financiamento do capital de giro para a unidade econômica e o papel predominante do capital investido em transporte, elevadores de grãos, armazenamento etc. temos, ante nós, novos modelos de penetração capitalista na agricultura. Os produtores vêem-se transformados em força de trabalho operando meios de produção alienados. Neste sentido, a despeito do caráter disperso e independente dos pequenos produtores de alimentos, a agricultura transformada num sistema econômico concentrado nas mãos de uma série de grandes empresas, através das quais ela é integrada às mais avançadas formas do capital financeiro. Não é por acaso que, em um exemplo oferecido por N. P. Makarov no contexto americano, somente $35 \%$ do total da renda agrícola permaneceu nas mãos dos produtores, enquanto $65 \%$ foi apropriado pelas ferrovias, armazenamento de grãos, irrigação e pelo capital comercial e financeiro.

Comparada com esta concentração vertical do capital, a transformação das unidades de produção de 10 em unidades de 100 e até 500 ha, com uma correspondente semi ou completa proletarização de um grande número de produtores, torna-se um mero detalhe. E se este desenvolvimento não ocorre, é claramente porque a exploração capitalista com base na concentração vertical proporciona maiores retornos do que a baseada no modelo horizontal. Além disso, em grande medida, os riscos são transferidos das empresas capitalistas para os produtores no modelo de concentração vertical. ${ }^{30}$

Esta sintética perspectiva agroindustrial é apresentada como conclusão do estudo básico de Chayanov sobre a economia camponesa que examinamos neste Capítulo. Entretanto, esta conclusão não faz parte da edição alemã original e foi introduzi da, pela primeira vez, na versão russa do mesmo trabalho. ${ }^{31} \mathrm{O}$ contexto sugere que esta inclusão fez parte da defesa, por parte da Escola de Chayanov, de uma política de cooperação

\footnotetext{
${ }^{30}$ Chayanov. op. cit., p. $310 \mathrm{ff}$.
${ }^{31}$ Cf. a Introdução de Chayanov na edição russa contida em La organización de la unidad económica campesina. Buenos Aires.
} 
vertical como uma forma de manter a estrutura básica da produção camponesa.

Uma análise mais detalhada mostra, também, que não há base para harmonizar os pontos de vista de Chayanov sobre a dinâmica da unidade camponesa com sua caracterização de subordinação desta última à agroindústria. De fato, Chayanov, na citação anterior, implicitamente reconhece este problema nas afirmações contraditórias sobre a articulação da agroindústria com a unidade de produção camponesa.

No parágrafo inicial, ele deixa espaço para sua teoria da determinação interna da dinâmica da unidade de produção camponesa ("embora as deixem livres no que tange à produção"...)

Entretanto, imediatamente após, ele reconhece que "a máquina comercial... também começa a interferir diretamente na organização da produção. Ela dita as condições técnicas, fornece as sementes e fertilizantes, determina os sistemas de rotação e converte seus fornecedores em executores técnicos de seus objetivos e de seu plano econômico".

Assim, neste contexto, não há mais qualquer espaço para a determinação da produção de acordo com o balanço trabalho-consumo, nem a absorção de força de trabalho externa pode ser vista como subordinada à determinação interna das condições ótimas para a utilização da força de trabalho familiar. O balanço trabalho/consumo não mais depende de critérios subjetivos, mas é predeterminado pelos novos custos de produção impostos pela agroindústria.

Como iremos argumentar em nossos estudos de caso, por maior que seja a validade da teoria de Chayanov para o caso do produtor camponês independente, qualquer lógica autônoma atribuível a este último é subvertida uma vez que a exploração seja subordinada aos meios de produção e ao controle técnico da agroindústria. Mesmo uma teoria chayanoviana reformulada no sentido em que sugerimos para incluir o fenômeno do trabalho externo é completamente inadequada à realidade da produção familiar subordinada aos capitais agroindustriais.

\section{Lênin: o camponês médio revisitado}

De forma paralela, Lênin também foi forçado a tentar adaptar sua análise em Development of Capitalism in Russia à inflexível realidade não- transitória do camponês. Tal reformulação foi forçada pelo impacto que a revolução de 1905 teve sobre ele:

A origem desse último erro estava no fato de que, definindo corretamente a direção do desenvolvimento, definimos de forma inexata o momento. Suponhamos que já se haviam cristalizado plenamente na Rússia os elementos da agricultura capitalista, tanto na economia dos latifundiários (exceção feita aos "otrezki" espoliadores, daí a reivindicação de que fossem devolvidas as terras), quanto na economia dos camponeses, em cujo seio nos parecia ter-se formado uma forte burguesia camponesa, que era incapaz de, consequentemente, realizar uma 'revolução agrária camponesa'. O que deu origem a esse programa equivocado não foi o "temor" à revolução agrária camponesa, e sim a superestimação do grau de desenvolvimento capitalista na Rússia (p. 78). ${ }^{32}$

Entretanto, embora no mesmo texto Lênin reconheça que a "diferenciação definitiva [sic] apenas começou", ${ }^{33}$ sua estratégia política formulada em escritos posteriores continuou a ser baseada numa extrapolação direta da tese da diferenciação com o camponês médio em processo de desaparecimento; a proposta leninista era de lutar para arrancar das mãos dos kulaks o proletariado rural e os camponeses "pobres".

Esta foi a perspectiva que guiou os desafortunados esforços de organizar "soviets" separados de trabalhadores rurais e comitês especiais para os camponeses pobres. E no período pós-revolucionário, tal perspectiva também levou à identificação de estocagem clandestina de gêneros pelos camponeses como um fenômeno especificamente kulak.

Foi somente em 1921, no contexto da questão agrária alemã, que Lênin admitiu a estabilidade de um campesinato médio empregador de força de trabalho e a necessidade de uma política específica para ele:

Por "camponeses médios", no sentido econômico, devem ser entendidos os pequenos agricultores que possuem, quer a título de propriedade, quer como arrendamento, pequenas parcelas de terra, de tal modo que, em primeiro lugar, proporcionem sob capitalismo, em regra geral, não só o rendimento necessário para sustentar pobremente sua família e sua exploração agrícola, mas também a

${ }^{32}$ Cf. Lênin, V. I. O programa agrário. São Paulo. 1980, p. 78.
${ }^{33}$ Op. cit., p. 77. 
possibilidade de obter certo excedente, que pode, pelo menos nos melhores anos, converter-se em capital; e que, em segundo lugar, permitam recorrer, em muitos casos (por exemplo: em uma de cada duas ou três explorações agrícolas), ao emprego de mão de obra assalariada. Um exemplo concreto de campesinato médio em um país capitalista avançado é oferecido na Alemanha, segundo o censo de 1907, pelo grupo de explorações de 5 a 10 ha, um terço das quais empregam operários assalariados. Na França, país em que estão os mais desenvolvidos cultivos especiais, por exemplo, a viticultura, que requerem maior emprego de mão de obra, o grupo correspondente emprega, provavelmente, em proporções ainda maiores o trabalho assalariado ("Esboço Inicial das Teses sobre a Questão Agrária para o II Congresso da Internacional Comunista" em O Problema Agrário 1 Coleção Fundamentos, p. 94-5).

De qualquer modo, Lênin claramente vê este estrato como essencialmente tendente a uma aliança com a burguesia; enfatiza que o camponês médio não pode ser atraído para o proletariado revolucionário e propõe, então, uma política de neutralização.

Além de uma mentalidade burguesa de "proprietário", Lênin argumenta que o camponês médio tem uma relação diretamente antagônica com a força de trabalho assalariada.

Assim, embora esta posição represente um avanço em relação à análise do caso russo, a contratação de força de trabalho não-familiar é identificada com uma inequívoca relação capitalista, e o fenômeno permanece isolado em um estrato específico da população camponesa.

\section{A exploração familiar e a agroindústria nos debates da Segunda Internacional}

Dado o incontestável peso de um campesinato médio, contratador de trabalho, no contexto europeu, os debates alemães da Segunda Internacional podem ser tomados como aqueles que fornecem o painel mais adequado do caráter contraditório do processo de trabalho na exploração familiar.

De fato, já no debate de Engels com os socialistas franceses, apresentou-se claramente a oportunidade de se incorporar uma análise mais sofisticada do processo de trabalho camponês. Os socialistas franceses, no seu Congresso de Nantes, haviam clamado por: proteção extensiva aos produtores que cultivam terras alheias sob o nome de arrendatários e parceiros (métayeurs) e que, se exploram os diaristas, é porque de certo modo se veem forçados a fazê-lo, devido à exploração de que eles mesmos são objetos. ${ }^{34}$

Engels comparou sarcasticamente tal posição com a defesa da exploração capitalista das grandes "plantations", embora, ao mesmo tempo, ele tenha reconhecido a existência deste tipo de produtor quando identificou o objeto da proposta dos socialistas franceses com os produtores da beterraba açucareira da França e Alemanha, subordinados ao capital agroindustrial:

$\mathrm{Na}$ verdade, o parágrafo citado só pretende referir-se a um caso especialíssimo, que é o seguinte: no norte da França, da mesma forma que em nossas regiões de cultivo de beterraba, o camponês toma em arrendamento a terra com a obrigação de cultivar beterraba e sob condições extremamente desfavoráveis. Os arrendatários são forçados a vender a beterraba a uma fábrica determinada e ao preço por esta fixado; são obrigados a comprar uma semente determinada e empregar uma quantidade fixa de adubo indicado, e além disso são vergonhosamente roubados quando entregam a colheita. Tudo isso é bem conhecido também na Alemanha...

Contudo, ele rejeita a perspicaz formulação dos socialistas franceses que identificaram, neste caso, o emprego de trabalho não-familiar como uma consequência da exploração intensificada resultante da subordinação à agroindústria, reduzindo este fenômeno a um "caso especialíssimo" sem relevância geral para uma caracterização global da produção familiar.

Embora no caso alemão o camponês empregador não pudesse ser ignorado, este camponês "médio" veio a ser caracterizado, quase exclusivamente como camponês "rico". Este é, em especial, o caso da análise de Kautsky, determinada pela luta contra a facção Vollmar/David do próprio Partido Alemão da Social-Democracia, que propunha um programa especial para a defesa das explorações familiares alemãs. ${ }^{36}$

${ }^{34}$ Cf. Engels, F. The Peasant Question in France and Germany citado da versão de A questão agrária em português, p. 68.

${ }^{35}$ Op. cit., p. $68-9$.

${ }_{36}$ Cf. Salvadori, Massimo. Karl Kautsky and the Socialist Revolution, 1880-1938, especialmente o capítulo dois: "The Fight Against Revisionism". 
Desta maneira, a reafirmada importância de Kautsky no contexto das discussões sobre a exploração familiar e a agroindústria não deriva de qualquer teorização da dinâmica contraditória do processo de trabalho na exploração familiar. ${ }^{37}$

Mais propriamente, a revivescência de Kautsky se explica pela ênfase que ele dá à subordinação da agricultura à indústria, que é ponto central em sua obra, e pela sua projeção de uma articulação entre a exploração familiar e a agroindústria que reduz o camponês à condição de um trabalhador disfarçado. Baseando-se nos relatórios do Parlamento inglês, Kautsky cita o caso dos produtores dinamarqueses submetidos às cooperativas de leite e, após detalhar os direitos destas com respeito à inspeção e controle do processo de produção, conclui:

Desta forma, o camponês, de dono de sua própria produção agrícola, converte-se, ele próprio, em um apêndice da produção industrial; tendo de submeter-se às demandas desta última, ele se transforma, em parte, em um operário. ${ }^{38}$

Contraste-se isto com a análise leninista da agroindústria, que focaliza exclusivamente o papel dela como um estímulo adicional à consolidação das explorações rurais capitalistas de larga escala, particularmente em consequência das novas demandas impostas pela qualidade da produção. ${ }^{39}$

Além disso, Kautsky estava ciente do caráter contraditório da consciência do trabalhador rural, admitindo que demandas por terra poderiam persistir em condições de efetiva proletarização. Diversamente, a exclusiva ênfase de Lênin sobre a promoção de uma aliança entre trabalhadores rurais e urbanos através da organização independente dos

\footnotetext{
${ }^{37}$ Uma nova reedição de A questão agrária de Kautsky apareceu recentemente no Brasil, refletindo a crescente discussão de seu trabalho na literatura corrente. Cf. Wanderley, M. N. B. "O camponês: trabalhador para o capital", Op. Cit., e Castro, A.C. e outros, Evolução recente e situação atual da agricultura brasileira. Também no contexto europeu, ver Mollard (cf. bibliografia).

${ }^{38}$ La cuestión agraria, p. 286

${ }^{39}$ Mas, de fato, os dados empíricos de Lênin referem-se quase exclusivamente à exploração agrícola em pequena escala e à agroindústria (fumo, beterraba-açucareira, batatas). Cf. p. 292-308 de Development of Capitalism in Russia. Kausty também tende a enfatizar as vantagens advindas da exploração em larga escala no contexto agroindustrial, mas ele entende isso como a capacidade da pr6pria exploração capitalista para se industrializar.
}

primeiros levou à imputação de uma consciência proletária unívoca ao "trabalhador rural possuidor de um lote de terra".

\section{Conclusão crítica}

Assim, enquanto Kautsky, e não Lênin, fornece o referencial clássico mais convincente, nem a tradição marxista nem a populista fornecem um esquema adequado para analisar a dinâmica peculiar da exploração familiar, e particularmente o papel estrutural do trabalho extrafamiliar, o qual desempenha uma função decisiva na evolução daquele tipo de exploração quando submetida à modernização.

Mais do que isto, a presença mais do que casual de tal tipo de trabalho é identificado explicitamente com a transição para uma exploração capitalista por todas estas correntes tradicionais, ainda que $\mathrm{r}$ partir de pontos de vista diferentes.

A debilidade peculiar da avaliação clássica marxista, do ponto de vista teórico, é o critério usado para a categorização das unidades de produção familiar, que são analisadas exclusivamente em termos de sua inserção diferenciada no mercado de trabalho. O camponês pobre vende sua força de trabalho, o rico compra a força de trabalhe dos outros e o camponês médio não faz nenhuma destas coisas. ${ }^{40}$

Tal abordagem apresenta duas falhas. Não permite uma análise das características específicas que estas unidades de produção camponesas têm em comum, corretamente salientadas pelos populistas e por Chayanov. $\mathrm{O}$ mais grave, porém, é que ela trata o mercado de trabalho como uma variável independente, ao invés de vê-lo como uma consequência da forma como a produção camponesa se integra à acumulação capitalista.

Argumentaríamos que tal integração deve ser o ponto de partida para caracterizar as dinâmicas da produção camponesa; a forma e o grau de subordinação ao capital permitem oscilações na articulação das unidades camponesas com o mercado de trabalho sem implicar, necessariamente, em proletarização ou "kulakização".

\footnotetext{
${ }^{40}$ Isto na versão original de Lênin. Uma vez que a participação dos camponeses "médios" no mercado de trabalho é reconhecida, eles são empurrados para dentro de uma ou outra das duas categorias básicas. A participação no mercado de trabalho tanto como comprador quanto como vendedor é excluída "a priori" de tal análise.
} 
Desta maneira, diferentes graus de trabalho extrafamiliar (seja venda ou compra) representam um contínuo definido pela persistência do agricultor como um produtor direto, e não forma necessariamente a base para uma caracterização de diferenciação de classe. ${ }^{41}$

A nosso ver, a ruptura qualitativa é determinada pelo grau em que a integração ao circuito da acumulação capitalista permite a transformação do produtor direto em um administrador exclusivo da força de trabalho de outros. Somente quando o recurso ao trabalho extrafamiliar é analisado como uma variável dependente é que seu verdadeiro lugar no processo de trabalho da produção familiar pode ser apreciado.

Portanto, a título de conclusão, afirmaríamos que nem a tradição leninista nem a populista, que estabeleceram as coordenadas básicas para a análise da produção familiar, são capazes de captar a dinâmica específica de seu processo de trabalho. Esta falha se toma crítica no contexto da ativa intervenção sobre esse processo que é a marca registrada da subordinação imposta pela agroindústria à produção agrícola.

Nos capítulos seguintes, iremos analisar as características específicas do setor minifundiário nordestino, submetendo a caracterização do "pequeno produtor", da forma como discutida no Capítulo Um, a uma reavaliação crítica. Além disso, iremos demonstrar o papel decisivo do trabalho extrafamiliar e seu crescente peso no contexto da consolidação de uma produção comercial. Ao fazê-lo, prepararemos a base para nossos estudos específicos sobre a modernização do pequeno produtor na Segunda Parte.

\footnotetext{
${ }^{41}$ É claro que isto não é negar a existência de um proletariado rural "possuidor de um lote de terra", como veremos no Capítulo Três.
}

Capítulo três - O pequeno produtor no Nordeste brasileiro

\section{Características específicas do pequeno produtor brasileiro e o debate feudalismo $x$ capitalismo}

O pequeno produtor, no Brasil de hoje, não tem ligações orgânicas com qualquer sociedade pré-capitalista. Não havia camponês feudal ou estrutura agrária indígena para se confrontar com os primeiros colonizadores. Em consequência, não há nenhuma das instituições típicas da sociedade camponesa voltadas para a manutenção de um equilíbrio entre terra e força de trabalho. Não há terras comunais submetidas à redistribuição periódica. ${ }^{1}$ Não há leis de herança protegendo contra a excessiva divisão da propriedade territorial. E, finalmente, não há leis matrimoniais específicas cujo objetivo seja o de estabilizar a oferta de força de trabalho ao longo das gerações. ${ }^{2}$

Além disso, o modelo da colonização portuguesa incluía a radical exclusão de qualquer dimensão camponesa. A integração produtiva da colônia na acumulação mercantil da metrópole foi estabelecida com base em plantações de larga escala, utilizando força de trabalho escrava despojada de qualquer controle jurídico ou material sobre os meios de produção.

Neste modelo, os elementos do campesinato foram reduzidos a fugas esporádicas dos escravos das "plantations". Isto era frequentemente acompanhado pela tentativa de criar comunidades agrícolas em bases comunais como no exemplo do famoso Quilombo dos Palmares. ${ }^{3}$ Entretanto, estes esforços comunais foram, por fim, militarmente esmagados, e não conseguiram estabelecer novos padrões permanentes de ocupação territorial.

\footnotetext{
${ }^{1} \mathrm{O}$ exemplo mais próximo poderia ser a criação comunal de gado no Sertão, um processo quase completamente erradicado pelo violento movimento de "fechamento de terras" dos anos recentes.

2 A preponderância de tais instituições desmente a afirmativa de Marx sobre a base individualista do camponês. Sua colocação deveria ser limitada ao campesinato pós-feudal, reestruturado à base dos direitos especificamente burgueses de propriedade.

${ }^{3}$ Para uma proveitosa avaliação geral, Cf. "Palmares, símbolo de liberdade". Cap. XIX de Brasil História. 1. Colônia, 1979, Ed. Brasiliense.
} 
Foi somente com a abolição da escravatura que se apresentou a possibilidade de uma alternativa camponesa. Entretanto, esta via foi juridicamente bloqueada pela Lei de Terras de 1850, fazendo o acesso à terra depender da sua compra. Isto excluiu os ex-escravos do Nordeste, que se viram forçados a migrar para as plantações de café, no Sul.

É no contexto desta situação de pós-escravidão que o debate "clássico" brasileiro sobre o campesinato ganha seu significado, sendo caracterizado essencialmente por interpretações conflitantes a respeito dos novos sistemas de parceria e arrendamento que emergiram no contexto pósescravatura, e que têm continuado, com peso decrescente, até os dias atuais. $^{4}$

Por todo um período, tomou-se senso comum entre as alas progressistas definir esta relação como feudal, vendo o parceiro como o equivalente brasileiro do camponês europeu, que foi forçado a ceder uma parte de sua safra ou o seu equivalente em dinheiro ou trabalho ao senhor feudal. Na verdade, tal paralelo não foi tanto com a Europa mas especificamente com a França, e estava vinculado a uma visão do desenvolvimento capitalista, que excluía a possibilidade da classe dos proprietários se transformar em empresários capitalistas. Esta visão reduziria, desta forma, a penetração capitalista na agricultura a uma via de mão única, a da reforma agrária, que levaria à "farmerização" e a um consequente processo de diferenciação.

Os opositores desta visão, particularmente Caio Prado Jr., enfatizaram a característica empresarial do latifundiário e a sua nominação completa sobre as condições que determinam o trabalho do produtor direto. Ele mostrou, em particular, quão flexíveis eram estas condições, e a facilidade com que os arranjos de parceria eram transformados em sistemas de remuneração monetária quando uma alta significativa dos preços tomava estes últimos mais rentáveis. ${ }^{5}$

Tal flexibilidade foi possível em função da completa falta de autonomia de parceiros e arrendatários. Ao contrário do camponês feudal

${ }^{4}$ Cf. artigos de Caio Prado Jr. da Revista Brasiliense republicados em A questão agrária, da Ed. Brasiliense. Sobre a tese feudalista, ver Guimarães, A. P. Quatro séculos de latifúndio e Vinhas, M. Problemas agrário-camponeses.

${ }^{5}$ Caio Prado. Op. cit., p. 65. ou das comunidades indígenas de outros países da América Latina, o parceiro/arrendatário não possuía seu principal meio de produção, a terra. ${ }^{6}$ Em muitos casos, ele não possuía sequer seus instrumentos de produção, frequentem ente contribuindo somente com sua força de trabalho, enquanto o latifundiário preparava a terra e fornecia os instrumentos. Resultou que nenhuma instituição jurídica ou militar foi necessária para assegurar a apropriação do excedente pelo latifundiário. Esta apropriação estava inscrita nas condições do acesso dos "pequenos produtores" aos meios de produção.

De forma semelhante, esta falta de controle ou de propriedade da terra é responsável por outra peculiaridade do parceiro/arrendatário brasileiro - sua extrema mobilidade, sujeita às mudanças nos padrões de exploração dos latifundiários (incorporação de terra para culturas de exportação, mudança para a exploração pecuária nos períodos mais recentes). A ausência de povoados camponeses no interior do Brasil testemunha esta mobilidade.

Os opositores da tese feudalista sustentam que nem os latifundiários nem os pequenos produtores podem ser comparados aos senhores e camponeses da Europa feudal. A dominação da estrutura agrária pelo latifundiário reflete a orientação mercantil dominante (potencial ou atual) dos grandes proprietários, e implica a exclusão do campesinato da posse de seus meios de produção. A completa falta de autonomia do pequeno produtor em relação à terra e, em consequência, com respeito à produção, tornam a caracterização deste estrato como campesinato, cabalmente inapropriada. ${ }^{7}$ Isto se revela de forma particularmente clara quando se considera a flexibilidade dos arranjos contratuais entre o produtor direto e o latifundiário, e na facilidade com que aquele se vê transformado em trabalhador assalariado. ${ }^{8}$

${ }^{6}$ A especificidade do setor do pequeno produtor brasileiro é que ele luta não para defender, mas para obter acesso à terra. Cf. Martins, J. de Souza. Os camponeses e a política no Brasil, Vozes, 1981, p. 15.

7 Cf. interessante artigo de Otávio G. Velho que tenta uma tipologia do "camponês" empregando o conceito de autonomia, em "Campesinatos e política", Anuário Antropológico, 1977.

${ }^{8}$ Deve ficar claro que, a despeito das posições políticas opostas dos "feudalistas" e de seus opositores, defendendo respectivamente, a priorização da extensão das leis trabalhistas ao campo e a reforma agrária, isto não é uma consequência necessária de seus pontos de vista teóricos. Um exemplo disto pode ser visto nos textos recentes de Wanderley, que se situa na 
Uma defesa modificada desta clássica posição antifeudal, especificamente para o Nordeste, foi renovada por Wanderley em texto recente. ${ }^{9}$ Embora reconheça a proliferação das pequenas propriedades fora do latifúndio, argumenta que as condições peculiares destas propriedades (pequeno tamanho e baixa fertilidade) não permitem que os minifundiários sobrevivam como produtores camponeses, forçando-os a uma variedade de papéis ocupacionais, primariamente sob a dependência do latifúndio, o que invalida sua caracterização como camponês:

Suponhamos um pequeno proprietário de 10 hectares na região semiárida do Nordeste. Ele sabe, pela própria experiência, que destes 10 hectares, só uns poucos - digamos três - possuem condições mínimas de fertilidade, que justifiquem sua exploração. É coerente com a lógica de sua situação que ele abandone a área restante e se dedique à exploração destes três hectares...

No entanto, esta pequena parcela é insuficiente para prover sua subsistência e ao mesmo tempo para ocupar a mão de obra de que dispõe... o pequeno proprietário aceita então explorar uma parcela de grandes propriedades vizinhas, em regime de parceria..." "Muito frequentemente, o uso da terra em parceria, nas grandes propriedades, é condicionado à prestação de trabalho diretamente nas 'plantations' do latifundiário... remunerado em salário, mas a um nível inferior ao médio da área.

Na parte 'abandonada' de sua própria terra, o pequeno proprietário muitas vezes aluga parcelas a terceiros... dos quais cobra uma pequena renda...

Finalmente, dada a dispersão de suas atividades no curso do ano agrícola, ele é muitas vezes obrigado a contratar um ou dois trabalhadores temporários - nos momentos da colheita - aos quais paga um salário.

De acordo com esta visão, o minifundiário, mesmo quando proprietário de suas terras, não pode ser apropriadamente definido como um camponês. Ele corresponderia melhor ao que Lênin caracterizou como trabalhador rural e proprietário de um lote de terra - força de trabalho atual,

tradição de Caio Prado mas defende a reforma agrária como a reivindicação central no campo.

${ }_{9}^{9}$ Wanderley, Maria de N. B. Algumas reflexões sobre o campesinato do Nordeste: Conceito e realidade. Ciência e Cultura, 29(5); 537-544. ou potencial para os grandes estabelecimentos. A tese "feudal" e suas críticas tinham em comum uma ênfase sobre o latifúndio como a "relação de produção fundamental" (Wanderley. Op. cit., p. 541) determinando a subordinação dos produtores diretos.

\section{2. "Farmerização" e fim do latifúndio}

Uma tentativa de contestar este último ponto de vista pode ser encontrada no trabalho de Gentil Martins Dias, tanto em seu livro, intitulado, de forma significativa, Depois do Latifúndio, ${ }^{10}$ quanto em um artigo mais recente, "The Brazilian Peasantry and the Development of Capitalism in the Twentieth Century". ${ }^{11}$

Uma alegação central para sua argumentação é a de que:

A estrutura da posse da terra no Brasil, no século 20, tem sido caracterizada por uma consistente e generalizada fragmentação de unidades de produção, com crescente acesso de um número muito maior de produtores à terra (“The Brazilian Peasantry...”, p. 1).

A partir daí, ele afirma:

O campesinato brasileiro tem uma variedade de possibilidades para seu desenvolvimento, podendo vir a tomar-se desde um lumpemproletariado até de pequenos capitalistas (Op. cit., p. 3).

Sua defesa empírica desta posição se baseia nos dados dos Censos da FIBGE sobre os estabelecimentos agrícolas e sua evolução de 1920 a 1970 , ao mostrar que o incremento nos pequenos e médios estabelecimentos (0100 ha) os quais foram "multiplicados por um fator correspondente a 9,58" - excede, de longe, o dos maiores estabelecimentos, sendo de 2,62 o índice de aumento para os de 100-1.000 ha; de 1,43 para os de 1.000-10.000 ha, e declínio numérico para os do estrato superior a 10.000 ha.

De forma semelhante, o avanço das pequenas e médias propriedades em termos de área é claro, aumentando de $8,97 \%$ para $23,5 \%$ do total de área ocupada, entre 1920 e 1970. Entretanto, também houve um aumento significativo na área ocupada pelos grandes estabelecimentos (100-1.000 ha), que avançaram de $27,64 \%$ para $36,96 \%$ no mesmo período. Os estratos

${ }^{10}$ Ed. Universidade de Brasília, 1978.

${ }^{11}$ Trabalho apresentado ao IX Congresso Mundial de Sociologia, Suécia, Upsala, 1978. 
dos estabelecimentos muito grandes e excepcionalmente grandes mostraram um declínio relativo na participação da área total.

Ao explicar este tipo de desenvolvimento, Dias enfatiza a importância da incorporação de novas áreas, que se tomaram acessíveis a partir da expansão da rede de estradas, e ressalta uma tendência geral da parte do grande capital em preferir o investimento urbano. Em consequência, ele conclui que:

uma expansão vigorosa da produção familiar rural ocorreu juntamente com um declínio das grandes unidades de produção rural (p. 7).

Na região Nordeste, Dias argumenta que isto produziu uma tendência de predominância de unidades familiares de produção descapitalizadas, submetidas não ao latifúndio, mas ao capital mercantil.

Embora os trabalhos de Dias forneçam muitos pontos individuais de valor e possam ser vistos como uma contribuição à tese da agroindústria, suas ambiguidades conceituais e metodológicas são suficientes para lançar dúvidas sobre suas conclusões a respeito do latifúndio e da característica camponesa do pequeno produtor do Nordeste.

Os dados empíricos básicos que ele usa para projetar o declínio do latifúndio são os dos Censos Agropecuários da FIBGE. ${ }^{12}$ Entretanto, a unidade de análise que estes Censos utilizam - o estabelecimento - não implica propriedade e, portanto, independência pelo menos formal do latifúndio. Se tomarmos os dados do Censo de 1975, de um total de 4.810.779 estabelecimentos, não menos de $36 \%$ é formado por parceiros ou posseiros. De forma semelhante, o declínio dos "muito grandes" e dos "excepcionalmente grandes" latifúndios não exclui uma dependência relativa entre o setor minifundiário e os grandes latifúndios, os quais ao que parece apresentaram expansão. ${ }^{13}$

Mais importante talvez é o truque conceitual que define "os vários grupos que habitam o Brasil rural como sendo basicamente de proprietários e não-proprietários". Tal ponto de vista exclui por definição o que

\footnotetext{
${ }^{12}$ Fundação Instituto Brasileiro de Geografia e Estatística.

${ }^{13} \mathrm{Se}$, como parece, a área atribuída ao pequeno estabelecimento é subtraída do latifúndio, o tamanho deste último está seriamente subestimado nos dados censitários.
}

Wanderley (ver acima), e outros descreveriam como a mais típica das características do "pequeno proprietário" - a de ser ao mesmo tempo um trabalhador do latifúndio.

Enquanto os minifundiários podem ver sua posição como aquela em que "são obrigados a vender eventualmente sua força de trabalho para complementar seus rendimentos e garantir sua subsistência"14 para os latifundiários este setor representa essencialmente uma reserva de força de trabalho. Ademais, a categoria central empregada por Dias para definir o pequeno produtor - unidades de produção até 100 ha - exclui por definição qualquer base para discernir os processos de diferenciação no interior deste estrato.

Dias atribui o declínio do latifúndio à maior rentabilidade dos investimentos urbanos/industriais no contexto do desenvolvimento capitalista da economia como um todo. Como em corolário, ele argumenta que a expansão das propriedades de maior tamanho no período recente dependeu exclusivamente de subsídios "artificiais" do governo. Ele ignora, assim, o papel estrutural das exportações agrícolas como condição para a expansão industrial continuada. E: isto que determina a necessidade de incentivos especiais para o investimento agrícola e, dada a correlação de forças ao nível do Estado, assegura ao grande capital os benefícios provenientes destes estímulos. Os incentivos da SUDENE, citados por Dias como um exemplo, favorecendo os vastos latifúndios nas áreas de fronteira do Nordeste, longe de serem "artificiais", foram os predecessores de políticas similares que atualmente favorecem o grande capital na produção de café, reflorestamento e produção de açúcar em articulação com o PROÁLCOOL.

Além destes estímulos específicos, as linhas de crédito preferencial para a agricultura, se bem que possam ser desviadas para investimentos urbanos, não deixam de estimular um processo de reconcentração latifundiária como condição para receber tal crédito. Se Dias tivesse incluído os dados do Censo da FIBGE para 1975, esta tendência em direção a uma "relatifundiarização" teria ficado evidente junto com a estagnação do estrato de 0-100 ha:

\footnotetext{
${ }^{14}$ Estrutura agrária, Graziano da Silva, p. 96.
} 
Tabela 7 - Número de estabelecimentos agropecuários, por extrato, para o Brasil:

\begin{tabular}{c|c|c|c}
\multicolumn{5}{c}{ período de 60/75 } \\
\hline Estratos (ha) & 1960 & 1970 & 1975 \\
\hline $0-100$ & 2.986 .435 & 4.454 .022 & 4.500 .809 \\
\hline $100-1.000$ & 314.831 & 414.746 & 446.170 \\
\hline $1.000-10.000$ & 30.883 & 35.425 & 39.648 \\
\hline $10.000 \mathrm{e}+$ & 1.597 & 1.449 & 1.820 \\
\hline \multicolumn{4}{|c}{ Fonte: Censos Agropecuários, FIBGE. }
\end{tabular}

Tabela 8 - Área dos estabelecimentos agropecuários, (em ha) por estrato para o

\begin{tabular}{c|c|c|c}
\multicolumn{5}{c}{ Brasil; período de 60/75 } \\
\hline Estratos (ha) & 1960 & 1970 & 1975 \\
\hline $0-100$ & 53.518 .671 & 69.153 .199 & 69.154 .283 \\
\hline $100-1.000$ & 86.029 .455 & 108.742 .676 & 115.923 .043 \\
\hline $1.000-10.000$ & 71.420 .904 & 80.059 .162 & 89.866 .944 \\
\hline $10.000 \mathrm{e}+$ & 38.893 .112 & 36.190 .429 & 48.951 .812 \\
\hline \multicolumn{4}{r}{ Fonte: Censos Agropecuários, FIBGE. ${ }^{15}$}
\end{tabular}

\section{O minifúndio - reserva de força de trabalho ou setor produtivo?}

Mas se a tese do declínio do latifúndio deve ser vista, no máximo, como uma tendência conjuntural mais do que estrutural, permanece a necessidade de categorização do setor do pequeno produtor. Para Dias, assim como para Sá, ${ }^{16}$ cujos pontos de vista refletem essencialmente os da SUDENE, ${ }^{17}$ nos anos 60 , a articulação entre a produção em pequena escala e o latifúndio ocorreu ao nível do capital mercantil mais do que ao da oferta de força de trabalho. ${ }^{18}$

Os defensores desta opinião, baseando-se nos quadros do Censo, apontaram para o declínio progressivo do trabalho temporário e para o enorme crescimento do trabalho familiar como uma proporção do trabalho total desde os anos 50:

\footnotetext{
${ }^{15}$ Estes dados são para o Brasil como um todo, na forma como Dias os usa, mas as mesmas proporções gerais mantêm-se para o Nordeste.

${ }^{16}$ Ver Capítulo Um, anterior.

${ }^{17}$ Para uma excelente avaliação da SUDENE cf. o Relatório da BINAGRI sobre o Nordeste, de 1978. Brasília (mimeo).

${ }^{18}$ Para Sá, isto se dá principalmente através dos arranjos de arrendamento, enquanto para
} Dias é o pequeno produto formalmente independente que predomina.
Tabela 9 - Categorias do trabalho rural para a região ${ }^{19}$ Nordeste; período de 50/75.

\begin{tabular}{l|c|c|c|c}
\hline Categoria & 1950 & 1960 & 1970 & 1975 \\
\hline Familiar & 2.460 .658 & 4.228 .682 & 6.321 .174 & 7.432 .915 \\
\hline $\begin{array}{l}\text { Emprego } \\
\text { permanente }\end{array}$ & 374.993 & 378.548 & 298.795 & 391.173 \\
\hline $\begin{array}{l}\text { Emprego } \\
\text { temporário }\end{array}$ & 1.172 .643 & 1.571 .909 & 642.745 & 657.024 \\
\hline Parceiros & 326.642 & 229.850 & 160.120 & 179.559 \\
\hline Outros & & 252.756 & 145.463 & 78.092 \\
\hline
\end{tabular}

Fonte: FIBGE, Op. cit.

Tais dados estão ligados à evidência de um marcado declínio do tamanho médio das unidades abaixo de 10 ha (de 3,65 em 1950 para 2,61 em 1975) e um incremento no número de pessoas ocupadas por unidade de exploração. Isto indicaria um processo de involução no setor minifundiário, agora visto como essencialmente externo ao latifúndio à luz dos dados do Censo, que assinalam um declínio do arrendamento e predominância da categoria dos posseiros.

Entretanto, os dados sobre a utilização máxima do trabalho temporário, recolhidos mês a mês, fornecem um panorama completamente diferente.

Se tomarmos, em primeiro lugar, os dados de 1970, veremos que, no mês de máximo emprego, a cifra referente ao trabalho temporário é o dobro da registrada na seção que trata do Pessoal Ocupado por categoria. Os valores para 1975 são ainda mais significativos, uma vez que a média geral para o trabalho temporário máximo por mês é o dobro da cifra "emprego temporário" nos dados sobre Ocupações por categoria. Igualmente importante é o incremento absoluto no trabalho temporário durante 197075 , da ordem de 500.000 por mês.

Se tomarmos o número médio de trabalhadores temporários por mês em 1975 - 1.265.000 - e supusermos que todo este trabalho temporário é fornecido pelo estrato de 0-10 ha, o qual compreende 1.641.931 propriedades no Nordeste, $77 \%$ destas propriedades teriam em média uma pessoa envolvida em trabalho temporário ao longo de todo o ano. E claro

${ }^{19}$ Os dados desta seção foram tirados do estudo de BINAGRI, Op. cit., e atualizados para 1975 pelo autor. 
que tal número poderia ser reduzido se os trabalhadores sem-terra ${ }^{20}$ fossem deduzidos. Contudo, tais dados são suficientes para indicar a importância da articulação ao nível do trabalho para o setor minifundiário.

\begin{tabular}{l|c|c}
\multicolumn{3}{c}{ Tabela 10 - Trabalho temporário na região Nordeste } \\
\hline \multicolumn{1}{c}{ Meses } & 1970 & 1975 \\
\hline Janeiro & 1.356 .705 & 1.499 .741 \\
\hline Fevereiro & 768.691 & 1.345 .082 \\
\hline Março & 809.904 & 1.177 .052 \\
\hline Abril & 538.759 & 1.046 .891 \\
\hline Maio & 822.399 & 1.655 .648 \\
\hline Junho & 735.856 & 1.264 .460 \\
\hline Julho & 573.148 & 1.099 .192 \\
\hline Agosto & 750.055 & 1.244 .317 \\
\hline Setembro & 874.058 & 1.342 .109 \\
\hline Outubro & 617.173 & 1.062 .654 \\
\hline Novembro & 592.933 & 990.329 \\
\hline Dezembro & 897.654 & 1.432 .594 \\
\hline
\end{tabular}

Fonte: FIBGE, op.cit.

Esta conclusão será compatível com os dados mencionados, referentes ao declínio do tamanho médio das parcelas deste estrato, e ao incremento paralelo do número de pessoas empregadas. Antes de refletir um processo de involução, isto sugeriria uma acentuação da dependência da renda obtida fora da propriedade (notar também o significativo incremento absoluto dos trabalhadores temporários no Censo de 1975) e um processo de proletarização disfarçada. ${ }^{21}$

Dados do Cadastro do INCRA, de 1972, confirmam tal visão. Calculase que cerca de 800.000 propriedades, no Nordeste (o conceito de propriedade do INCRA exclui arrendatários e parceiros), eram incapazes de subsistir com base em rendas próprias. Desta forma, isto implicaria que no mínimo um número igual de pessoas trabalharam parte do ano como trabalhadores temporários.

${ }^{20}$ Aqui, os trabalhadores sem-terra são interpretados em seu sentido mais estrito, como aqueles sem acesso à terra sob quaisquer condições.

${ }_{21}$ Cf. Crédito rural e pequena produção em Tucano, Paulo Amorim, 1980, Salvador (mimeo). Pesquisa baseada numa amostra de produtores do estrato de 0-10 indica que 53\% da renda total foi gerada fora da propriedade.
Este aspecto do minifúndio apontaria também para sua decrescente importância como produtor de alimentos para os mercados urbanos. Os dados do INCRA são particularmente significativos sob este ponto de vista:

Tabela 11 - Produção de gêneros alimentícios de acordo com o tamanho da propriedade, na região Nordeste.

\begin{tabular}{c|c|c|c|c}
\hline Estrato & $\begin{array}{c}\text { Número de } \\
\text { propriedades }\end{array}$ & $\%$ & $\begin{array}{c}\text { Área total } \\
\text { ha }\end{array}$ & $\begin{array}{c}\text { Área total } \\
\%\end{array}$ \\
\hline $0-10$ & 241.305 & 34,8 & 619.745 & 9,0 \\
\hline $10-100$ & 336.941 & 48,6 & 3.791 .214 & 55,1 \\
\hline 100 & 116.140 & 16,6 & 2.472 .640 & 35,9 \\
\hline \multicolumn{2}{r}{ Fonte: Adaptada de BINAGRI. Op. cit., p.36. }
\end{tabular}

No caso da Bahia, que será a área específica de nossa análise em relação ao Programa POLONORDESTE (e é um estado onde o arrendamento e a parceria são fenômenos de significação apenas localizada), calculamos a quantidade de produção comercializada ${ }^{22}$ para os seguintes gêneros alimentícios - feijão, milho, mandioca e arroz - usando os dados do Censo de 1970, do IBGE.

Embora a participação do estrato 0-10 ha seja maior nos dados da Bahia, isto reflete seu peso numérico proporcionalmente maior. O que é mais importante, entretanto, é a coincidência de ambos os grupos de dados com respeito ao estrato médio, que se mostra o maior fornecedor de gêneros alimentícios.

Tabela 12 - Produção e comercialização de gêneros alimentícios selecionados de acordo com o tamanho da propriedade.

\begin{tabular}{c|c|c|c|c|c}
\hline $\begin{array}{c}\text { Estrat } \\
\text { o }\end{array}$ & $\begin{array}{c}\text { Número de } \\
\text { propriedade } \\
\mathrm{s}\end{array}$ & $\begin{array}{c}\text { Produção } \\
(\mathrm{t})\end{array}$ & $\begin{array}{c}\text { Produçã } \\
\mathrm{o} \\
(\%)\end{array}$ & $\begin{array}{c}\text { Comercializaçã } \\
\text { o } \\
(\mathrm{t})\end{array}$ & $\begin{array}{c}\text { Comercializaçã } \\
\text { o } \\
(\%)\end{array}$ \\
\hline \multicolumn{5}{|c}{ Feijão } \\
\hline $0-10$ & 149.804 & 69.558 & 31 & 27.824 & 19,4 \\
\hline $\begin{array}{c}10- \\
1.120\end{array}$ & 108.158 & 115.509 & 48 & 83.862 & 57,9 \\
0 & 18.486 & 42.305 & 21 & 32.305 & 22,27 \\
\hline 100 & &
\end{tabular}

${ }^{22}$ Calculamos a comercialização na base de $40 \%$ da produção no estrato 0-10 ha, o que é provavelmente uma superestimação do produto líquido comercializado, e descontamos por igual o consumo interno para cada estrato. 


\begin{tabular}{|c|c|c|c|c|c|}
\hline \multicolumn{6}{|c|}{ Milho } \\
\hline $0-110$ & 132.874 & 102.691 & 30 & 41.077 & 18,9 \\
\hline $\begin{array}{c}10- \\
1.110\end{array}$ & 102.227 & 175.899 & 51 & 128.875 & 59,4 \\
\hline 100 & 17.930 & 65.117 & 19 & 56.870 & 21,7 \\
\hline \multicolumn{6}{|c|}{ Mandioca } \\
\hline $0-110$ & 135.137 & 817.082 & 32 & 326.733 & 19,7 \\
\hline $\begin{array}{c}10- \\
1.100\end{array}$ & 89.743 & $\begin{array}{c}1.257 .96 \\
6\end{array}$ & 50 & 934.892 & 56,4 \\
\hline 100 & 14.924 & 448.403 & 18 & 394.677 & 23,9 \\
\hline \multicolumn{6}{|c|}{ Arroz } \\
\hline $0-110$ & 12.256 & 8.346 & 30 & 3.338 & 19,6 \\
\hline $\begin{array}{c}10- \\
1.100 \\
\end{array}$ & 11.782 & 12.789 & 46 & 8.077 & 47,4 \\
\hline 100 & 3.127 & 6.864 & 24 & 5.614 & 33,0 \\
\hline
\end{tabular}

Os dados acima, juntamente com nossas cifras anteriores sobre o trabalho temporário, apontam para a heterogeneidade do estrato de 0,50 ha, que compreende o público privilegiado do Programa POLONORDESTE, oscilando num extremo para um proletariado rural possuidor de um lote de terra, e no outro para a unidade de produção familiar, com esmagadora predominância do primeiro. Pode-se fazer uma ideia desta divisão se se examinam os dados do Censo, distinguindo o estrato de 0-10 ha do de 1050 ha.

Análises com base no tamanho da propriedade têm considerável validade para o Nordeste, uma vez que o grau de capitalização destas propriedades é extremamente baixo. Entretanto, considerando-se os diferentes níveis de fertilidade e, particularmente, o acesso diferencial aos mercados, devemos tratar estas divisões do estrato com uma certa flexibilidade.

Comparando os dois estratos em termos de área ocupada com culturas e pastagens, somente 3\% da categoria de 0-10 ha cultiva mais do que cinco hectares, enquanto que para o estrato de 10-50 ha este número é de $33 \%$. Cerca de $34 \%$ do estrato de $0-10$ ha tem a média de 2,8 ha de pastagens, enquanto que para o estrato de 10-50 ha este valor sobe para $66 \%$, com a média de 13,3 ha
Embora os meios de produção no intervalo de 0-50 ha se reduzam quase completamente a terra e trabalho, houve um incremento significativo no uso de arados, de 21.171 unidades em 1960 para $219.571 \mathrm{em} 1975{ }^{23}$ Uma vez que os arados puxados a trator representam proporção insignificante deste número $(0,05 \%)$, e são usados principalmente em propriedades com mais de 50 ha, iremos considerar somente a tração animal.

No caso da Bahia, 73\% dos arados de tração animal são utilizados em propriedades com menos de 50 ha. No universo do estrato de $0-10$ ha, isto corresponde a somente $6 \%$ destas propriedades, aumentando porém para $13 \%$ no caso do estrato de $10-50$ ha.

Assim, usando-se este critério de tamanho de estrato como um reflexo indireto das tendências que estão agindo sobre o setor minifundiário, a existência de uma divisão estrutural pareceria ser confirmada. $^{24}$

\section{Análise dos sistemas de produção e o setor minifundiário}

No estudo da BINAGRI, já mencionado anteriormente, é realizado um esforço pioneiro para se ir além das limitações destes dados agregados. Baseando-se particularmente no trabalho de Mário Lacerda de Melo, ${ }^{25}$ este estudo reanalisa os dados do Censo de acordo com os sistemas de produção predominantes no Nordeste. $\mathrm{O}$ argumento central desta abordagem é que a dinâmica de transformação no setor agropecuário do Nordeste deriva do desenvolvimento diferenciado de um certo número de sistemas de produção orientados predominantemente para o mercado.

Além disso, sustenta-se que o setor minifundiário é um produto destes sistemas e, desta forma, pode ser melhor entendido em termos de uma articulação ao nível da oferta de força de trabalho. E, finalmente,

\footnotetext{
${ }^{23}$ Estes dados foram obtidos dos Censos Agropecuários de 1960, 1970, 1975.

${ }^{24}$ Sorj recoloca o clássico conceito da "diferenciação social" distinguindo a "diferenciação horizontal" da "diferenciação vertical"; a primeira se refere a uma divisão entre famílias produtoras tradicionais e modernizadas, e a segunda à tese leninista da proletarização, "kulakização". Entretanto, Sorj reconhece que esta distinção é de caráter descritivo-analítico, e não pretende também hierarquizar uma outra tendência ou identificar suas causas específicas. Ver Estado e classes sociais na agricultura brasileira, Op. cit.

${ }^{25}$ Regionalização agrária do Nordeste. SUDENE, Recife, 1978.
} 
afirma-se que tal abordagem é capaz de especificar as condições limitadas sob as quais foi capaz de emergir um setor modernizado de produção de gêneros alimentícios, baseado em estabelecimentos de médio porte, e dependente do trabalho assalariado.

Melo define dez sistemas de produção básicos para o Nordeste. $\mathrm{O}$ documento da BINAGRI seleciona seis deles como representantes da estrutura básica do setor agropecuário: cana-de-açúcar, cacau, gado e policultura, gado-algodão, agropastoril-extrativista e sistemas de "baixa ocupação". Destes, os dois últimos são fundidos no que define como "frentes pioneiras", ou sistemas de ocupação de fronteira. Além disso, está claro no corpo do texto que os sistemas de Melo denominados "combinações agropastoris com lavouras" estão incluídos no sistema "gado combinado com lavoura". Desta forma, o documento da BINAGRI incorpora virtualmente todos os sistemas dominantes indicados por Melo. ${ }^{26}$

\subsection{Sistemas de produção da cana-de-açúcar e do cacau}

O ponto inicial desta análise é uma rejeição da abordagem que tenta interpretar o minifúndio em função da suposta estagnação do setor exportador. ${ }^{27}$ Baseando-se na ampla documentação atual das áreas de produção do açúcar e do cacau, ${ }^{28}$ o documento mostra que ambos os sistemas incorporam 200.000 ha adicionais sob cultivo desde os anos 50 . Em ambos os casos, esta expansão levou à expulsão dos moradores, anteriormente figuras típicas destas "plantations", e à sua transformação, principalmente em trabalhadores temporários sem terra. Houve também um acréscimo de bolsões de minifúndios, cuja área média tendem a decrescer.

\footnotetext{
${ }^{26}$ Um sistema de significado particular para a Bahia é - excluído - o de pecuária melhorada. Iremos tocar nisto mais adiante, neste capítulo.

${ }^{27}$ Cf. Planos diretores da SudENE.

${ }^{28}$ Para a região açucareira: Cassacos e corumbas, M. T. S. de Melo Suarez, São Paulo, 1967; A terra e o homem no Nordeste, M. C. Andrade, São Paulo, 1973; Os clandestinos e os direitos, Lygia Sigaud, São Paulo, 1977; e para o cacau: Fazendas de cacau na Bahia, Clóvis Caldeira, São Paulo, 1954; "Mão-de-obra e elementos de relações de produção", in Diagnóstico socioeconômico da região Cacaueira. CEPLAC/IICA, Bahia, 1976, por Maria Bianchi dos Reis; "Produção, emprego e estrutura agrária na região Caucaueira da Bahia", P. G. C. de Rezende, in Pesquisa e Planejamento Econômico, 8, 1978, Rio de Janeiro.
}

A demanda por este trabalhador temporário na prática foi aumentada, uma vez que a expansão da produção se deu pela expansão da área cultivada e não através de aumentos na produção por hectare. ${ }^{29}$

Em ambos os casos, estamos lidando com monocultura ${ }^{30}$ cuja expansão se deu às custas da produção de subsistência dentro das próprias "plantations", e, no caso do açúcar, começou a ocupar as tradicionais áreas de culturas alimentares do Agreste.

Propriedades de tamanho médio são inexpressivas no sistema de produção do açúcar. Embora exista um estrato de pequenas a médias propriedades na região do cacau, elas também estão dedicadas à produção do cacau. ${ }^{31}$ Os minifúndios nesta área, de acordo com pesquisa conduzida pela CEPLAC, ${ }^{32}$ dependem em mais de $50 \%$ de sua renda de "atividades fora da propriedade", e sua produção própria está reduzida à mandioca. A dinâmica destes dois sistemas, portanto, exclui o desenvolvimento de um setor significativo especializado na produção de alimentos, e as condições de reprodução do minifúndio são determinadas pela expansão de culturas comerciais e pelas oportunidades de trabalho sazonal nas "plantations".

\subsection{O sistema gado-algodão}

O sistema gado-algodão, dominante no Sertão, tem uma dinâmica muito diferente da que acabamos de descrever para as regiões costeiras. Aqui, o gado e o algodão complementam um ao outro. As incertezas do mercado impediram que o algodão se tornasse claramente a forma dominante de exploração, e as difíceis condições ecológicas, por sua vez, tornaram impossível para o gado deslocar a produção do algodão. Enquanto a lucratividade do gado levou à substituição da parceria pelo trabalho assalariado, o contrário ocorreu com respeito ao algodão. Neste último caso, substituiu-se inteiramente trabalho pago em salário por parceria e arrendamento. Tanto o parceiro quanto o arrendatário tinham suas

${ }^{29} \mathrm{Na}$ área do cacau, o elevado uso de pesticidas também aumentou a demanda por tal tipo de trabalho.

${ }^{30}$ Embora, na região do cacau, a banana esteja, de forma geral, associada com o cacau, sua função é a de fornecer sombreamento e umidade, não sendo considerada uma cultura comercial.

${ }^{31}$ Para uma boa avaliação disto Cf. Resende, $O p$. cit.

${ }^{32}$ Cf. "Mão-de-obra e elementos de relações de produção", Op. cit. 
condições de produção determinadas pelo latifundiário e recebiam a terra já preparada para o plantio, preparo este executado pelo trabalhador temporário contratado pelo latifundiário e pago em salário. Não havia nenhuma diferença material, portanto, na autonomia relativa de arrendatário e parceiros. No período mais recente, mesmo este elemento do trabalho assalariado tem sido progressivamente eliminado, e a administração da área cedida tem-se tornado, de forma crescente, responsabilidade do parceiro/arrendatário.

A eliminação do trabalho assalariado e a recriação de formas nãocapitalistas pareceria derivar sua lógica tanto da incerteza de mercado e, em decorrência, dos altos riscos envolvidos, quanto da escassez de trabalhadores sem-terra no Sertão. A ampliação da autonomia aparente do parceiro/arrendatário no período recente reflete uma mudança na articulação entre o minifúndio e o latifúndio. Este último tem-se afastado cada vez mais das responsabilidades diretas ao nível da produção, e agora assegura sua expropriação do excedente através dos mecanismos do capital mercantil.

E dentro dos termos deste sistema que a análise de $\mathrm{Sa}^{33}$ tem sua validade, e, pelas razões que ele elabora, trata-se de um sistema que não cria condições para um processo de diferenciação no âmbito do setor minifundiário. ${ }^{34}$

\subsection{O sistema da fronteira}

"Frente pioneira" é o conceito usado pelo documento da BINAGRI para explicar a dinâmica da agricultura nas regiões de fronteira. A discussão está limitada ao caso do Maranhão e, como iremos ver mais tarde, não se aplica da mesma forma às outras principais regiões de fronteira do Nordeste situadas no Estado da Bahia.

A ocupação desta região toma a forma de uma "frente de expansão" de produtores de subsistência expulsos das "plantations" ou retirantes do Sertão, particularmente devido às secas dos anos 50 . Cerca de $25 \%$ de todos os novos estabelecimentos no Nordeste no período 50-70 surgiram nesta

\footnotetext{
${ }^{33}$ Cf. nossa discussão no Capítulo Um.

${ }^{34}$ Maluf, Renato S. J. A expansão do capitalismo no campo: o arroz no Maranhão UNICAMP, IFCH/DEPE, tese de mestrado, 1977, mimeo (citada em BINAGRI, p. 154).
}

região. Foi aí que se desenvolveu o grupo mais assemelhado a um campesinato clássico no Nordeste.

A penetração do capital mercantil ${ }^{35}$ produziu, entretanto, uma crescente comercialização da produção no caso do arroz, a qual levou, por sua vez, a uma progressiva mercantilização do principal meio de produção - a terra. É através da privatização da terra que a "frente de expansão" se torna uma "frente pioneira". Entretanto os benefícios desta privatização não são os produtores de subsistência originais. Estes são deslocados pelos pecuaristas e proprietários especuladores, que tomam posse da terra pela força pagando, quando muito, um preço de compensação simbólico. ${ }^{36}$ Desta forma, desencadeia-se um processo de acumulação primitiva no qual a terra é transformada em capital e os produtores de subsistência em trabalhadores ou arrendatários temporários nos novos latifúndios recém-constituídos.

Uma saída (temporária) desta sujeição só é possível através da abertura de novas terras de fronteira, as quais, entretanto, uma vez consolidadas, passam a sofrer as mesmas transformações. Os novos arrendatários são duplamente subjugados: aos latifundiários, que exigem que as terras devolvidas sejam preparadas para a instalação de pastagens, evitando assim o plantio de lavouras permanentes; e ao capital mercantil, que financia a produção de arroz e assegura que ocorra acumulação nas mãos do produtor.

\subsection{O sistema da pecuária melhorada}

Em todos os sistemas anteriores, vimos que é mínima a oportunidade para o desenvolvimento de um setor de pequenos produtores autônomos. O mesmo é válido para o único sistema que o documento da BINAGRI não discute e que é de grande importância para o caso da Bahia - o sistema da produção pecuária melhorada. ${ }^{37} \mathrm{~A}$ definição deste sistema envolve as regiões onde a ocupação da terra ocorreu com base na produção pecuária comercial, e onde a tendência foi a criação de melhores linhagens de animais, baseada na expansão de terras com pastagens permanentes.

\footnotetext{
${ }^{35}$ Cf. Lemos, Maurício Borges. Um estudo comparativo sobre as formas de organização de produção de arroz no Brasil. Campinas, 1977, tese de mestrado.

${ }^{36}$ Cf. Robin Murray sobre a importância da "renda dos fundadores" como um estímulo para a expansão capitalista: "Valor e teoria da renda" in Capital and Class, 4, 1978

${ }^{37}$ Cf. Mário Lacerda de Melo, Op. cit. Cap. 5, p. 171 e seguintes.
} 
O setor minifundiário nestas regiões tomou tradicionalmente a forma de arrendamento de pequenas áreas do latifúndio para culturas alimentares de ciclo curto. Isto foi possível por conta da característica geograficamente elástica da atividade pecuária. Na estação chuvosa, o gado é capaz de pastar numa área muito reduzida do latifúndio, permitindo o cultivo de lavouras de ciclo curto naquelas áreas que irão ser cedidas ao pastoreio na estação seca, quando as pastagens se tomam escassas. Desta forma, as áreas plantadas foram importantes para o latifundiário, uma vez que se converte em pastagem natural. $\mathrm{O}$ setor minifundiário também foi importante para a abertura de novas áreas a serem subsequentemente incorporadas como pastagens naturais.

A concessão de terras pode ser vista, assim, como o pagamento para a abertura de novas áreas no latifúndio, e do ponto de vista deste, o minifundiário foi essencialmente uma forma especial de força de trabalho. Entretanto, a evidência sugere que o latifundiário não interferiu ao nível da comercialização, e os minifundiários foram deixados livres para vender seu excedente.

Assim, este sistema permitiu um desenvolvimento significativo de culturas alimentares de ciclo curto, apesar da subordinação do minifúndio ter impedido a ocorrência de um processo de diferenciação. Contudo, a tendência dominante neste sistema é no sentido da expulsão dos pequenos arrendatários, na medida em que a demanda para a limpeza de áreas encapoeiradas tem diminuído e a tendência de se implantarem pastagens permanentes tem aumentado. Em grandes áreas da Bahia, este processo já está bem avançado, e o setor minifundiário tem sido drasticamente reduzido.

\subsection{O sistema de pecuária e policultura}

O sistema de pecuária e policultura apresenta muitas similaridades com os sistemas anteriores já descritos. A criação de gado foi a base histórica de ocupação dessas áreas, e estabeleceu um padrão de posse de amplas áreas de terra. Entretanto, a menor fertilidade média destas terras e, em consequência, o menor valor comercial do seu gado, permitiram um nível mais alto de produção agrícola, particularmente daquelas culturas capazes de resistir às secas - sisal e algodão. $\mathrm{O}$ setor minifundiário foi capaz de desenvolver-se em muito maior grau, porque não havia uma tendência forte para o estabelecimento de pastagens permanentes. A menor lucratividade global do setor pecuário nestas regiões e a existência de bolsões de terras mais férteis capacitaram o desenvolvimento de lavouras de alimentos em escala comercial, dirigidas para os mercados urbanos em expansão.

É significativo a este respeito que as propriedades de 5 a 50 ha têm aqui um peso maior do que nos outros sistemas já discutidos. Igualmente significativo é o marcante incremento de propriedades com menos de 5 ha, que não podem ser consideradas como reservas de força de trabalho para os latifúndios pecuaristas, e seriam melhor explicadas como supridoras de mão de obra para as unidades de médio porte produtoras de gêneros alimentícios para os mercados urbanos. Desta forma, é este sistema que apresenta, mais que qualquer outro, as condições para um processo de diferenciação no setor de pequena produção de gêneros alimentícios.

\subsection{Avaliação e ressalvas necessárias}

Esta tentativa de reinterpretar os dados agregados referentes aos sistemas de produção tradicionalmente dominantes na área é particularmente importante, uma vez que permite uma definição das diferentes características da subordinação do minifúndio e estabelece as condições sob as quais os produtores "simples", produtores de mercadorias agrícolas, podem consolidar-se dentro do setor de pequena produção. Além disso, tal tentativa de reinterpretação serve como uma importante referência para se analisar a dinâmica diferencial dos vários programas de desenvolvimento rural integrados no Nordeste.

Todavia, algumas ressalvas precisam ser feitas. A primeira delas se refere ao tratamento das regiões de fronteira. A ocupação é vista como ocorrendo à base de comunidades de pequenos produtores voltados para a agricultura de subsistência, que são expropriadas em seguida, num processo de acumulação primitiva favoreceu o grande capital e o estabelecimento de um sistema de propriedade privada dominado pelos latifundiários. Tal modelo clássico, entretanto, está sendo substituído por um padrão de ocupação pioneira das regiões de fronteira pelo grande capital - um movimento promovido e dependente dos programas estatais de crédito 
subsidiado. ${ }^{38}$ No caso das duas regiões de fronteira remanescentes no Nordeste, situadas no extremo oeste e no sul da Bahia, o crédito subsidiado do programa 34/18, ${ }^{39}$ da SUDENE, tem assegurado a ocupação destas terras sob a forma de grandes propriedades desde o início, favorecendo especialmente a criação do gado e o reflorestamento. Analisando os fundos liberados pela SUDENE para os 50 programas agrícolas aprovados até 1976, cerca de Cr\$ 850 milhões de um total de Cr\$ 950 milhões são alocados em programas nestas regiões de fronteira. ${ }^{40}$ Com base numa Comissão Parlamentar de Inquérito, Moniz Bandeira conclui que 10\% do território da Bahia passou para as mãos de estrangeiros. ${ }^{41}$

O capital estatal e do Centro-Sul também desempenharam um papel de importância na ocupação destas regiões de fronteira. No sul da Bahia, onde a fronteira está sendo ocupada principalmente com base no reflorestamento, uma única subsidiária estatal - a FLONIBRÁs - detém mais de 200.000 ha. Além do reflorestamento, ambas estas áreas de fronteira têm sido incluídas no zoneamento para a produção de cana-de-açúcar em larga escala, no contexto do ProÁlCOOL. As regiões restantes do Extremo-Oeste têm-se transformado em áreas de colonização dos produtores de soja e de trigo vindos do Rio Grande do Sul.

Os subsídios estatais não somente promoveram um novo padrão de ocupação da fronteira; eles também têm eliminado o papel tradicional do setor minifundiário nestas regiões, desde que as políticas de crédito dos anos 70 facilitaram o desmatamento mecânico das florestas e capoeiras. Além do mais, os produtores sulistas tendem a contar com sua própria força de trabalho importado. ${ }^{42}$

Estas transformações, estimuladas essencialmente pelos subsídios agrícolas da década de 70, não se limitaram às áreas de fronteira. Ao enfocar exclusivamente os sistemas de produção históricos do Nordeste o que foi, em parte, determinado pela disponibilidade de dados sistemáticos, o

\footnotetext{
${ }^{38}$ Já existe uma substancial literatura sobre este "fechamento da fronteira"; cf. "The Frontier and the State in Brazil: a Case Study of the Amazon", M, Pompermayer, Stanford University, 1979; Frentes de expansão e estrutura agrária, Zahar, 1981.

$39 \mathrm{Um}$ esquema de abatimento fiscal para promover investimentos do Centro-Sul no Nordeste.

${ }^{40}$ Cf. SUdEne, Incentivos fiscais na Bahia, 1978.

${ }^{41}$ Cartéis e desnacionalização, de Moniz Bandeira, Civilização Brasileira, 1975.

${ }^{42}$ Cf. Jornal do Brasil de 8/2/81.
}

estudo da BINAGRI subestimou o grau em que novos subsistemas estão sendo criados em resposta aos programas especiais do Governo e às linhas de crédito.

Uma indicação indireta pode ${ }^{43}$ ser obtida através dos dados de crédito rural para o Nordeste, os quais mostram que o crédito de investimento para a implantação de novas culturas permanentes aumentou em tomo de 25 vezes entre 1969 e 1976, subindo de 9,59\% para $24,92 \%$ dos investimentos totais. Deste investimento, cerca de $40 \%$ foi dirigido para "outras culturas permanentes", não incluídas nos sistemas tradicionais do estudo da BINAGRI.

Além disso, culturas que tinham sido quase eliminadas estão agora sendo vigorosamente promovidas pelos programas especiais do Governo, como é o caso do café, particularmente no Estado da Bahia. ${ }^{44}$ Cerca de 400.000 ha foram considerados disponíveis e aptos para o café na Bahia (excluindo áreas aptas porém ocupadas com outras atividades, isto é, outras atividades dominantes), ou seja, uma área igual à dedicada à atividade cacaueira. Desta cifra, 70.000 ha já foram plantados, incorporando largas extensões do sistema da pecuária e policultura. Em uma destas áreas, que também é objeto de um programa de desenvolvimento rural integrado, 6 milhões de um total de 7,5 milhões de pés de café estão divididos entre três plantações. Nesta mesma área, estima-se que, se atingir o regime de plena produção, a demanda por força de trabalho será o dobro de toda a população dos doze municípios vizinhos. ${ }^{45}$

Estes novos padrões de ocupação não estão restritos às regiões de fronteira nem a "programas especiais" específicos, mas formam parte da crescente subordinação da agricultura à indústria. Como foi mencionado no Capítulo Um, o setor agrícola brasileiro está agora sendo submetido a políticas de zoneamento, nas quais áreas específicas são declaradas aptas para culturas particulares. ${ }^{46}$ A liberação de crédito para culturas específicas

${ }^{43}$ Cf. Crédito rural 1969-76, v. IV, Região Nordeste, Ministério da Agricultura, 1977, Brasília.

${ }^{44}$ Cf. A penetração do café na Bahia, CEPLAC, 1979, Bahia.

${ }^{45}$ Op. cit., p. 51 e 57.

${ }^{46} \mathrm{Tal}$ zoneamento, naturalmente, também é submetido aos interesses do grande capital. Na Bahia, a atual área de reflorestamento é muitas vezes maior que o zoneamento para esta atividade. 
está dependente de sua adequação à área, conforme os pareceres do zoneamento. Desta forma, haverá uma tendência de diversificação crescente na agricultura do Nordeste, e a criação de uma variedade de subsistemas sujeita aos critérios técnicos e de lucratividade. Esta industrialização da agricultura implica grande heterogeneidade no setor minifundiário.

Este desenvolvimento é de particular importância para o sistema de pecuária e policultura. Analisado sem destaque entre os demais no estudo da BINAGRI, este sistema de fato compreende cerca de 33\% da área agrícola total do Nordeste (dez vezes a área do cacau e cana-de-açúcar somados). Por incluir também a maior parte das terras férteis fora das regiões da costa e da fronteira, esta área foi um foco particular para a aplicação das linhas de crédito mais altamente subsidiadas disponíveis nos anos $70{ }^{47} \mathrm{O}$ processo de diferenciação que o estudo da BINAGRI registrou no setor minifundiário dentro deste sistema deveria, portanto, ser reconsiderado à luz de seus desenvolvimentos mais recentes.

A regionalização detalhada dos dados do Censo conduzida pelo estudo da BINAGRI estabelece claramente a importância do setor minifundiária como uma fonte de força de trabalho. Entretanto, esta reserva de mão de obra é vista quase exclusivamente em relação ao setor latifundiário. A única exceção a isto é a sugestão da emergência localizada de unidades de porte médio baseadas no trabalho assalariado, o que é visto claramente como o início do desenvolvimento de um setor de produção agrícola capitalista voltada para o mercado interno.

\section{A unidade familiar e o trabalho temporário}

Nos capítulos anteriores, enfatizamos o grau em que a exploração familiar tradicional é estruturalmente dependente do trabalho contratado, e a do Brasil não é exceção. Dada a falta de instituições voltadas à proteção do trabalho familiar, como se assinalou no início deste Capítulo, seria previsível que tal dependência fosse particularmente acentuada. Com relação à região de fronteira do Maranhão, onde um "campesinato clássico" temporariamente foi capaz de emergir, constatamos a importância de sistemas de ajuda mútua. De forma semelhante, inúmeros estudos tomaram

\footnotetext{
${ }^{47}$ Para uma excelente avaliação geral destas novas políticas de crédito, cf. Crédito rural no Nordeste e os serviços complementares, Jorge Coelho, 1975, mimeo.
}

clara a preponderância da troca de trabalho nos costumes da exploração familiar do Nordeste. ${ }^{48}$

As peculiaridades regionais também tenderiam a acentuar tal dependência. Baixos níveis de fertilidade do solo tomam necessário o cultivo de áreas relativamente grandes, e as condições climáticas do Nordeste exigem, por sua vez, que o ciclo agrícola seja sincronizado para todos os produtos cultivados no estabelecimento, o que envolve uma utilização máxima de trabalho em cada fase. Com isso, é de se esperar que a articulação ao nível da oferta de trabalho não esteja limitada ao latifúndio, mas também ocorra no interior do setor minifundiário.

Os dados de trabalho temporário são significativos a este respeito. Se, em primeiro lugar, tomarmos os dados do INCRA indicativos da proporção entre trabalho temporário e trabalho familiar, nos períodos de emprego máximo para propriedades com menos de 50 ha, acharemos o seguinte ${ }^{49}$ :

\begin{tabular}{c|c|c|c}
\multicolumn{2}{c}{ Tabela 13 - Proporção entre trabalho temporário e trabalho familiar. } \\
\hline Estrato (ha) & $\begin{array}{c}\text { Trabalho } \\
\text { familiar máximo } \\
(\%)\end{array}$ & $\begin{array}{c}\text { Trabalho } \\
\text { familiar mínimo } \\
(\%)\end{array}$ & $\begin{array}{c}\text { Trabalho } \\
\text { temporário (\%) } \\
\text { máximo }\end{array}$ \\
\hline $0,5-2$ & 95,8 & 70,9 & 26,0 \\
\hline $2-5$ & 92,9 & 63,7 & 31,4 \\
\hline $5-10$ & 89,6 & 59,6 & 33,5 \\
\hline $10-25$ & 83,2 & 54,1 & 35,0 \\
\hline $25-50$ & 75,0 & 43,3 & 42,3 \\
\hline \multicolumn{4}{|c}{ Valor da Produção $(C r \$)$} \\
\hline $0-3000$ & 87,8 & 51,7 & 41,1 \\
\hline $3000-6000$ & 79,8 & 48,0 & 39,0 \\
\hline
\end{tabular}

Fonte: INCRA.

Como sempre, os dados do INCRA excluem arrendatários e parceiros, referindo-se apenas aos produtores independentes (proprietários). A proporção do trabalho temporário é significativa mesmo na menor destas propriedades, e para aquelas com mais de 25 ha assume importância igual a do trabalho familiar.

${ }^{48}$ O mutirão no Nordeste, Hélio Galvão, Rio de Janeiro, 1959 e Mutirão: formas de ajuda

mútua no meio rural, Clóvis Caldeira, São Paulo.
${ }_{9}$ Dados adaptados de cálculos de Estrutura agrária e produção de subsistência na agricultura brasileira, J. F. Graziano Silva (coord.), 1978, HUCITEC, p. 102. 
As dimensões do trabalho temporário no setor do pequeno produtor tomam-se mais claras se tomarmos os dados do IBGE, de 1975, para o Brasil como um todo (Tabela 14).

Estes dados mostram, portanto, que em média $60 \%$ de todo o trabalho temporário é absorvido por propriedades de até 50 ha. O Censo de 75 revela que cerca de $24 \%$ de todas as propriedades de $0-10$ ha emprega trabalho temporário, cifra que sobe a $31 \%$ para o estrato de $10-50$ ha.

De forma ainda mais significativa, os dados de 75 mostram um acréscimo de $22 \%$ no número de propriedades de 0-10 ha empregando trabalho temporário, e um acréscimo de $11 \%$ para o estrato de 10-50 ha, quando comparados com os dados de 1970, embora o número das propriedades de $0-10$ ha tenha crescido em $3 \%$ e o das propriedades de 10 50 ha tenha diminuído em $3 \%$ no mesmo período.

Tabela 14 - Trabalho temporário máximo por mês de acordo com o tamanho dos estabelecimentos ${ }^{50}$

\begin{tabular}{l|c|c|c|c}
\hline \multicolumn{1}{c|}{ Meses } & \multicolumn{2}{|c|}{$0-50 \mathrm{ha}$} & \multicolumn{2}{c}{$50 \mathrm{ha}$} \\
\hline Janeiro & 1.500 .193 & $(63 \%)$ & 876.960 & $(37 \%)$ \\
\hline Fevereiro & 1.321 .015 & $(62 \%)$ & 801.926 & $(38 \%)$ \\
\hline Março & 1.353 .207 & $(60 \%)$ & 879.964 & $(40 \%)$ \\
\hline Abril & 1.276 .054 & $(60 \%)$ & 846.947 & $(40 \%)$ \\
\hline Maio & 1.758 .865 & $(64 \%)$ & 949.369 & $(36 \%)$ \\
\hline Junho & 1.340 .973 & $(60 \%)$ & 861.037 & $(40 \%)$ \\
\hline Julho & 1.120 .561 & $(59 \%)$ & 754.354 & $(41 \%)$ \\
\hline Agosto & 1.174 .984 & $(62 \%)$ & 706.161 & $(38 \%)$ \\
\hline Setembro & 1.272 .532 & $(61 \%)$ & 802.976 & $(39 \%)$ \\
\hline Outubro & 1.142 .074 & $(55 \%)$ & 904.160 & $(45 \%)$ \\
\hline Novembro & 1.149 .585 & $(54 \%)$ & 968.106 & $(46 \%)$ \\
\hline Dezembro & 1.702 .671 & $(56 \%)$ & 1.310 .802 & $(44 \%)$ \\
\hline
\end{tabular}

Fonte: FIBGE, Censo 1975

Mesmo no caso de São Paulo, onde a articulação do trabalho temporário com o latifúndio é mais pronunciada, uma média de $42 \%$ de todo o trabalho temporário estava empregada em propriedades de menos de 50 ha, de acordo com os dados do Censo do IBGE para 1975. Além disso, a participação do setor de pequenas propriedades na contratação de trabalho temporário aumentou de $40 \%$ para $42 \%$ desde 1970 , mesmo com a redução

\footnotetext{
${ }^{50}$ Calculado do Censo do IBGE, 1975, Brasil, v. I.
}

de 2.126 no número de propriedades deste tipo e com o acréscimo de 2.492 unidades acima de 50 ha.

Para o Estado da Bahia os dados são da mesma ordem com 54\% em média de todo o trabalho temporário empregado em propriedades com menos de 50 ha. Esta é a mesma proporção verificada em 1970, embora apenas 515 novas propriedades tenham sido registradas no estrato 0-50 ha contra 6.048 para o intervalo superior a 50 ha, tendo havido um acréscimo de 583.589 trabalhadores temporários no mesmo período.

Estes dados poderiam ser confrontados com o que chamamos de processo de "relatifundiarização" desencadeado nos anos 70 como um produto do crédito fortemente subsidiado para o setor agrícola. Já mostramos os dados para o Brasil como um todo (cf. Tabela 7, neste Capítulo). O mesmo processo também tem dominado a estrutura agrária do Nordeste, como os dados da Tabela 15 indicam.

Tabela 15 - Quantidade e área de estabelecimentos agrícolas - Nordeste\%

\begin{tabular}{c|c|c|c|c|c|c|c|c}
\hline & \multicolumn{2}{|c|}{1950} & \multicolumn{2}{c|}{1960} & \multicolumn{2}{c|}{1970} & \multicolumn{2}{c}{1975} \\
\hline Tamanho (ha) & $\mathrm{n}^{\circ}$. & Área & $\mathrm{n}^{\circ}$. & Área & $\mathrm{n}^{\circ}$. & Área & $\mathrm{n}^{\circ}$. & Área \\
\hline $0-10$ & 53,2 & 2,8 & 61,7 & 4,3 & 68,3 & 5,5 & 69,0 & 5,4 \\
\hline $10-50$ & 27,7 & 9,3 & 23,6 & 12,0 & 20,4 & 13,8 & 19,0 & 13,0 \\
\hline $50-100$ & 7,8 & 7,9 & 6,3 & 9,6 & 5,1 & 10,5 & 4,9 & 10,0 \\
\hline $100+$ & 11,3 & 80,0 & 8,0 & 74,1 & 61,1 & 70,2 & 7,1 & 72,6 \\
\hline
\end{tabular}

Fonte: FIBGE, Censos Agropecuários

A despeito desta estagnação numérica e atual declínio em área, o estrato 0-50 ha manteve sua parte majoritária no emprego do trabalho temporário. O visível incremento do setor latifundiário, desta forma, não levou a um incremento proporcional na absorção do trabalho temporário. Pareceria que, nesta fase, a tendência fundamental tem sido um avanço do capital especulativo ou do capital aplicado em pecuária levando à simples expulsão do setor minifundiário. ${ }^{51}$ Mais ainda, esta expulsão parece ter afetado preferencialmente aquela fração de pequenos produtores que não empregam trabalho temporário.

\footnotetext{
${ }^{51}$ Entretanto, esta tendência pode ser invertida no próximo período com renovada expansão do café e particularmente da cana-de-açúcar como resultado do novo programa energético baseado no álcool
} 
Como vimos acima, as proporções dos estabelecimentos que contratam força de trabalho (temporário) no estrato 0-50 ha aumentou no período 70-75, e o crescimento absoluto no número dessas propriedades que empregam mão de obra assalariada excedeu de longe o crescimento numérico global das propriedades de 0-50 ha. De forma semelhante, embora haja picos claramente discerníveis na demanda por trabalho temporário no setor do pequeno produtor, eles não são tão pronunciados quanto comumente se supõe. Tomando a demanda média mensal por trabalho temporário no setor da pequena propriedade para o Brasil como um todo (1.342.726), podemos ver que em nenhum mês a demanda atual cai abaixo de $83 \%$ deste valor. No caso da Bahia, este valor nunca é inferior a 63\%. Em qualquer área, estes picos na demanda por trabalho irão tender a coincidir, tornando difícil imaginar que a demanda por trabalho possa ser suprida principalmente através de formas de troca de trabalho.

Todos os fatores apontados acima tenderiam, desta forma, a favorecer o ponto de vista de que existe uma divisão significativa no setor da pequena propriedade entre uma massa de semiproletários, que são forçados a vender parte de sua força de trabalho, e um setor de exploração familiar dependente, em variados graus, do emprego de trabalho temporário.

Constatamos anteriormente que as propriedades empregadoras de trabalho assalariado tenderam a escapar ao processo de "relatifundiarização", e que seu número relativo aumentou desproporcionalmente durante os anos 70, junto com uma intensificação do trabalho temporário assalariado. Isto estaria sugerindo uma correlação entre o acréscimo no uso do trabalho temporário e o incremento na mercantilização da produção nestas propriedades.

As evidências da Bahia tenderiam a confirmar tal conclusão. Embora o número médio de propriedades do intervalo de 0-50 ha que empregue força de trabalho (contratada) seja de $25 \%$, este valor cresce até $60 \%$ no caso dos pequenos produtores de fumo, de acordo com pesquisa realizada em 27 municípios do Estado. ${ }^{52}$ De forma semelhante na região produtora de feijão de Irecê, intensamente comercializada, dados de pesquisa realizada com 182 pequenos produtores no intervalo de $0-50$ ha mostram que mais de

\footnotetext{
${ }^{52}$ Cf. Fumo na Bahia - diagnóstico preliminar, CEPA-Ba, Salvador, 1980
}

$50 \%$ recorrem ao trabalho temporário assalariado, e $45 \%$ haviam empregado mais do que três trabalhadores no ano anterior. ${ }^{53}$

Todavia, a semiproletarização da maioria do setor minifundiário não pode ser entendida como uma consequência da ascensão destas unidades de produção simples de mercadorias, mas sim como o produto histórico da base latifundiária da agricultura capitalista no Brasil.

No período recente, este processo tem sido acelerado tanto pela purificação das relações capitalistas nas "plantations" comerciais, quanto pela acumulação primitiva levada a cabo pelo grande capital no período mais recente. A crescente marginalização física do setor da pequena propriedade (expulsão das áreas mais férteis, queda da área média etc.), combinada com uma progressiva mercantilização das condições de reprodução nas áreas rurais, têm produzido uma ainda maior dependência da renda monetária obtida fora da propriedade, principalmente através do assalariamento direto.

De forma semelhante, é provável que a mercantilização da força de trabalho tenha tendido a eliminar formas não-monetárias de troca de serviços, acentuando a inviabilidade de muitas unidades de produção hipótese que irá ser explorada em detalhes em nossos estudos de caso da Segunda Parte.

Por outro lado, os padrões preferenciais da dominação pelo latifúndio pelo capital mercantil, combinados com a expansão do mercado urbano para gêneros alimentícios, têm possibilitado o desenvolvimento de uma camada de produtor simples de mercadorias no estrato do pequeno produtor ${ }^{54}$ Inicialmente, o tamanho da propriedade, a disponibilidade de força de trabalho familiar, as condições para a renda diferencial terão determinado este desenvolvimento. Entretanto, sua consolidação vem se tornando cada vez mais dependente da capacidade desses produtores para absorver força de trabalho temporária, a qual, a nosso ver, está tomando cada vez mais a forma de assalariamento simples.

53 Pesquisa sobre associativismo entre os pequenos produtores rurais de Irecê, SEPLANTEC-CPE, 1981. Iremos examinar detalhadamente o programa de modernização da pequena produção em Irecê, no Capítulo Seis.

${ }_{54}$ Fique claro que não estamos afirmando que a produção simples de mercadorias menores esteja limitada a este estrato. Nosso interesse pelo estrato de 0-50 ha deriva de sua definição com o público dos programas de desenvolvimento rural integrado 
Diríamos então que tanto a dependência da renda obtida fora da propriedade, por um lado, quanto a dependência do trabalho extrafamiliar, por outro, têm sido determinadas pelos efeitos gerais da expansão capitalista (envolvendo a mercantilização de todos os elementos da reprodução, especialmente terra e trabalho), e pelas formas específicas da dominação capitalista na agricultura.

\section{Conclusão}

Podemos concluir, portanto, que o público dos programas de modernização do pequeno produtor compreende na sua maior parte uma massa altamente instável de pequenos produtores em parcelas de tamanho inviável, em vários estágios de proletarização e crescentemente ameaçados de completa expropriação. Em contraste, existe também uma camada emergente de explorações familiares orientadas comercialmente, cujas condições de expansão são determinadas pela organização preferencial dos sistemas de produção dominantes na região e cuja consolidação, ao que parece, está ligada a uma crescente dependência do trabalho temporário derivado do próprio setor da pequena propriedade.

$\mathrm{Na}$ Segunda Parte iremos examinar o impacto diferencial dos programas de modernização da pequena exploração sobre diferentes regiões e tipos de público, baseando-nos em três estudos de caso realizados no Estado da Bahia. Iremos concentrar nossa análise na dinâmica da modernização da pequena produção e especialmente sobre o significado do trabalho extrafamiliar neste processo. Ao fazê-lo, esperamos lançar novas luzes sobre a recente noção de subordinação direta ou real defendida pelos teóricos da agroindústria e discutida no Capítulo Um.

\section{Segunda parte}

\section{Introdução}

O Estado da Bahia está bem representado na distribuição de Projetos de Desenvolvimento Rural Integrado (PDRI) no Nordeste, contando com seis projetos distintos, se for incluído o Projeto Especial de Colonização (PEC) - serra do Ramalho, de responsabilidade do INCRA.

Este último projeto, que será analisado no Capítulo Cinco, embora não considerado formalmente um PDRI, recebe seu financiamento do POLONORDESTE, e em termos de extensão rural, crédito oficial e políticas de comercialização é idêntico aos demais.

A experiência do POLONORDESTE na Bahia, no entanto, evidencia claramente a validade da análise de sistemas de produção revista no Capítulo Três. Dos cinco PDRI's, um está no estágio inicial de implementação, e portanto não se apropria a uma investigação do seu impacto. Outro projeto se localiza na região cacaueira, e após cinco anos de sucessivas redefinições não conseguiu consolidar qualquer atividade voltada para os pequenos produtores. Destino semelhante caracteriza o PDRI do além-São Francisco, numa região objeto de uma ocupação ao estilo de uma fronteira nova, estimulada pelos incentivos da SUDENE.

Nossa pesquisa é baseada por isso nos três projetos que conseguiram sustentar uma intervenção modernizadora, sistemática, junto a um público claramente identificado como pequenos produtores, no Estado da Bahia nos últimos cinco anos.

Dos dois PDRI's, o da bacia do Paraguaçu representa a situação mais típica na região Nordeste do Brasil, tratando-se de uma região dominada pelos interesses de grandes pecuaristas. Além disso, o envolvimento direto do Banco Mundial (BIRD) neste projeto, com a garantia de recursos humanos e financeiros que isto implicou, tem permitido uma intervenção contínua e sistemática nessa região difícil.

Nossa análise deste projeto (vide Capítulo Quatro) baseia-se fundamentalmente na interpretação de dados retirados de relatórios da Unidade Técnica, responsável pela coordenação geral da execução do projeto. Tivemos também acesso aos resultados de uma pesquisa conduzida pelo Banco do Brasil na região. Várias visitas à área, inclusive com 
entrevista junto aos órgãos executores do projeto (extensão rural, agências de banco, cooperativas), assim como entrevistas abertas junto ao públicometa do projeto, proporcionaram uma base valiosa para a avaliação crítica dos dados disponíveis.

O PEC/Serra do Ramalho, do INCRA, que envolve aproximadamente 4.000 famílias, com direito ao uso de lotes de 20 ha cada, organizadas numa série de núcleos residenciais conhecidos como agrovilas, foi objeto de uma pesquisa de campo sistemática, realizada pela Comissão Estadual de Planejamento Agrícola da Bahia (CEPA-Ba), na coordenação da qual o autor teve uma participação direta.

A pesquisa objetivou avaliar a evolução do PEC como um todo, e a efetiva utilização do crédito oficial foi escolhida como a principal variável para a seleção do público a ser pesquisado. Uma amostra aleatória foi definida para garantir a representatividade em termos de área cultivada e agrovila de residência, aplicando-lhe um questionário formal. Nossa análise do Capítulo Seis limita-se aos elementos do questionário que dizem respeito diretamente às questões desta tese.

O terceiro estudo de caso localiza-se em Irecê. Além dos dados coletados diretamente das principais instituições envolvidas no projeto (Banco do Brasil, EMATERBA) e de entrevistas com o público-meta do POLONORDESTE, o autor teve acesso aos questionários de um levantamento realizado pela EMATERBA, o que permitiu retrabalhar os dados de acordo com a temática desta tese.

Na Segunda Parte, examinamos estes projetos separadamente, mostrando como a dinâmica específica de cada é determinada pelo macrocontexto socioeconômico. Os três capítulos estão organizados de acordo com o grau de modernização de pequenos produtores, começando com o Paraguaçu, onde esta modernização está menos consolidada. Este estudo toma claro o peso decisivo do sistema de produção dominante (a pecuária extensiva e melhorada, representativa de boa parte do Nordeste brasileiro) da frustração dos esforços para modernizar o setor minifundista. Entretanto, ao mesmo tempo, possibilita caracterizar alguns elementoschave do impacto de uma estratégia de modernização sobre os pequenos produtores.
Nossa análise continua com uma investigação do PEC/Serra do Ramalho, que, em função de seu isolamento das pressões imediatas da estrutura latifundista tradicional do Nordeste, favorece a maior incorporação dos elementos básicos da estratégia de modernização, o que permite avançar nossa análise das tendências básicas que esta modernização provoca.

Concluímos nossos estudos de caso com uma análise da região de Irecê, cujas características atípicas - propriedades de todos os tamanhos utilizam o mesmo sistema de produção, baseado na produção comercial de alimentos para o mercado interno - a transformam num exemplo do mais avançado processo de modernização de pequenos produtores tradicionais. As contradições da estratégia de modernização para o processo de trabalho da tradicional propriedade familiar aparecem, então, da maneira mais nítida no caso de Irecê, nos permitindo uma base para criticar o POLONORDESTE, que vai além de ataques relacionados com sua seletividade ou ineficácia em face da estrutura fundiária, focalizando a própria dinâmica desta estratégia de modernização.

Em nossa conclusão, situamos esta política de modernização no contexto geral da subordinação da propriedade familiar ao capital agroindustrial, e usamos os resultados dos estudos de caso como base para iniciar uma crítica das teses prevalecentes que interpretam esta modernização como expressão da subordinação real do processo de trabalho da propriedade familiar ao capital. 


\section{Capítulo quatro - PDRI Paraguaçu: a modernização do pequeno produtor à sombra do latifúndio}

\section{Caracterização da região}

Se a análise de sistemas de produção (vide Capítulo Três, em diante) tivesse sido observado na escolha de regiões para os vários programas de PDRI's, a bacia do Paraguaçu na Bahia não teria sido incluída. De fato, não fazia parte da seleção original de pólos de desenvolvimento, a partir dos critérios de áreas homogêneas e alto potencial produtivo. ${ }^{1}$

Sua inclusão resultou de uma pressão muito forte aplicada a nível estadual no período em que a orientação do POLONORDESTE vacilava ambiguamente entre a priorização de áreas como potencial para o crescimento e do público-meta de pequenos produtores. $\mathrm{O}$ projeto original para a bacia do Paraguaçu refletiu esta ambiguidade ao apresentar um conjunto de quatro subprojetos diferentes, nos quais o apoio para a pecuária pesou em pé de igualdade com a orientação à pequena produção. ${ }^{2}$

Com a produção de sisal e fumo ao leste e a agressiva expansão do café ao oeste, esta imensa região se caracteriza essencialmente como uma zona de pecuária extensiva e melhorada; aí menos de $10 \%$ da área total é dedicada às lavouras, parcela essa que se manteve mais ou menos constante ao longo dos últimos 25 anos.

Dentro da região o fumo e a mamona têm sido as principais lavouras comerciais, ${ }^{3}$ embora, por um lado, ocupassem apenas uma

${ }^{1}$ Elaborada pelo SCET/INTERNATIONAL/SIRAC, uma consultoria francesa em convênio com o governo federal. Na sua formulação inicial o programa do POLONORDESTE se baseou numa concepção de modernização em termos de "Pólos de Desenvolvimento" e representou mais uma aplicação das teorias difusionistas do que uma orientação específica para pequenos produtores.

Os quatro projetos foram elaborados com base em propostas contidas no Diagnóstico Preliminar (CPE, Bahia, 1971) e compreendem: 1. Projeto de Irrigação Utinga/Bonito; 2. Fruticultura; 3. Pecuária; 4. Pequena Produção.

${ }^{3}$ O açúcar e o sisal, embora cercando esta região, se concentram fora da área do Programa. Deve-se acrescentar, também, que a produção de fumo é específica à região de Feira de Santana e não típica da região como um todo. parcela pequena da área total dedicada à agricultura e, por outro, mostrassem pouco dinamismo ao longo dos anos. Segundo o Censo Agropecuário de 1975, a área cultivada com fumo - 8.095 hectares - foi menos que a verificada em 1950, quando 9.097 hectares foram plantados. Por sua vez, a mamona apresenta um declínio desde a década de $60 .^{4}$

Quanto aos demais, a produção agrícola tem se limitado a basicamente três alimentos - mandioca, milho e feijão - com uma área média cultivada por produtor inferior a 2 ha, produzido essencialmente para consumo próprio, verificando-se a comercialização apenas em mercados locais. Os bolsões isolados de agricultura irrigada ou pequena escala e de fruticultura só confirmam este retrato geral.

Por outro lado, as pastagens representam mais de $50 \%$ da área total, com quase a metade ocupada com pastagens plantadas. Esta conversão à pastagem plantada acelerou-se na década de 70, levando ao declínio absoluto no número de pequenas propriedades em duas das três principais subáreas, e um aumento pequeno na terceira, na medida em que a pastagem acaba com a produção de lavouras alimentares de curto ciclo nas grandes propriedades.

Este avanço da pecuária foi fortemente estimulado pela expansão do crédito subsidiado, especialmente com a vinda do PROTERRA, ${ }^{5}$ no início da década de 70. Segundo o relatório do Banco Mundial sobre crédito na área do Paraguaçu, ${ }^{6}$ em 1973, 76\% do crédito rural destinavam-se à pecuária, subindo para 90\% em 1976, bastante acima da participação média do crédito à pecuária no Estado como um todo, que em meados da década girava em torno de $60 \% .^{7}$

\footnotetext{
${ }^{4}$ As cifras são as seguintes em toneladas: 1960 - 15,150; 1970 - 11,826; 1975 - 8,633, com base nos dados para a sub-região da chapada Diamantina que mais produziu. Fonte: Censo Agropecuário, Bahia, Op. cit.

${ }^{5}$ Veja Capítulo Um para uma discussão deste programa. Com o colapso de suas propostas mais radicais veio a ser a linha principal de crédito subsidiado para a agricultura no Nordeste. ${ }^{6}$ PDRI - Paraguaçu, Relatório $n^{\circ} 5$, Crédito Rural, 1977. O Banco Mundial produziu uma série de relatórios sobre a região como parte do seu apoio financeiro ao PDRI.

${ }^{7}$ Fonte: Crédito Rural, 1969-76, Banco Central. A porcentagem dedicada a crédito na Bahia
} fica bem acima da média para o Nordeste que se mantém em tomo de $35 \%$. 
Os efeitos deste processo estão bem documentados no diagnóstico produzido pelo Centro de Pesquisas e Estudos (CPE) da SEPLANTEC, que indica ter havido a estagnação da pequena produção, levando à migração, especialmente de jovens trabalhadores, a tal ponto que "há na região uma crise de mão de obra".

8 "Vales úmidos da bacia de Paraguaçu" CPE/Ba, 1975, citado em Desenvolvimento rural no Nordeste: a experiência do POLONORDESTE, PIMES 80.

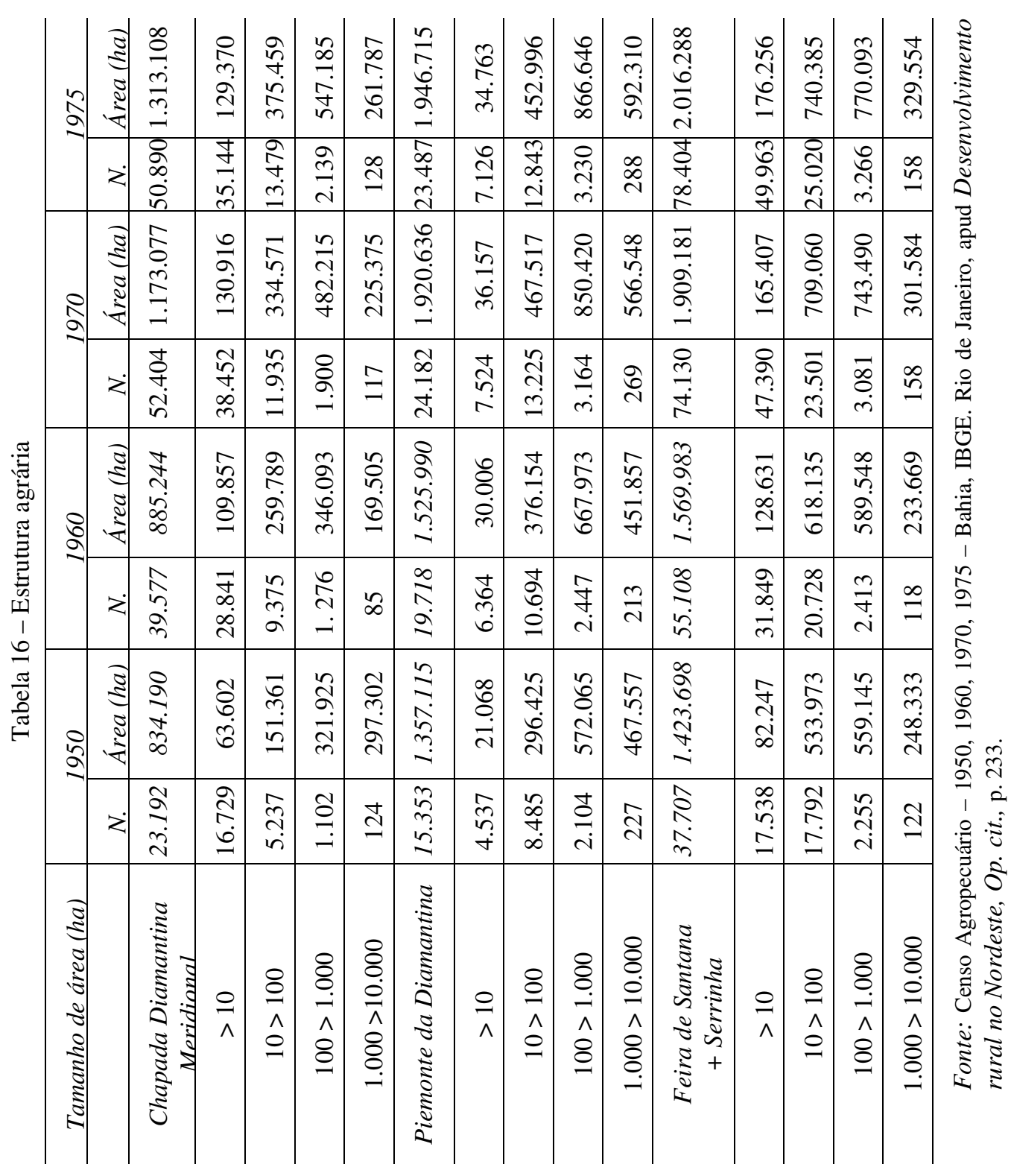


Esta pressão sobre o pequeno produtor continuou aumentando na segunda metade da década de 70 com a dramática expansão das plantações de café, afetando principalmente os doze municípios na margem ocidental do projeto, onde a participação do número de pés plantados cresceu de $1 \%$ a $25 \%$ do total estadual no quinquênio 1972-77. . $^{9}$ Com uma previsão de 400.000 hectares aptos para o café nesta região, a procura de terra tem sido intensa, atraindo capital do Centro-Sul do país, e até mesmo das multinacionais. Embora parte significativa da região seja esparsamente habitada, a grilagem já se intensificou no município de Utinga (área destinada à irrigação em pequena escala no projeto do POLONORDESTE) e "não tardará que se manifeste a solicitação por terras adicionais, que exatamente estão ocupadas por economias de produção de alimentos". ${ }^{10}$

Aqueles não diretamente ameaçados com expulsão deverão ser pressionados em direção a vários graus de proletarização, tendo em vista que serão criados aproximadamente 300.000 empregos, mais do que o dobro da população desses doze municípios.

Como mostra a Tabela 16, os pequenos produtores experimentaram uma redução absoluta tanto em número de estabelecimentos quanto em área na década de 70 nas duas subáreas que incluem a maior parte dos municípios incorporados ao PDRI. Na área toda do projeto, de acordo com o Censo Agropecuário de 1970, 80\% dos estabelecimentos tinham menos que 50 ha, e detinham apenas $16 \%$ da área ocupada.

O contexto no qual este PDRI opera, então, é de um público atomizado, espalhado nos interstícios de grandes propriedades de pecuária e café, cultivando pequenas áreas com lavouras alimentares para consumo próprio, e constantemente ameaçado de expulsão, à medida que o crédito subsidiado e a infraestrutura implantada pelo Estado estimulam a concentração de terra.

\section{O público do POLONORdeste}

Como vimos anteriormente, a formulação original do PDRI Paraguaçu teve orientação para os pequenos produtores como apenas um dos seus componentes. A distribuição do crédito nos primeiros dois anos

\footnotetext{
${ }^{9}$ A penetração do café na Bahia, CEPLAB-Ba, 1979

${ }^{10}$ Ibid., p. 104
}

demonstrou um nítido predomínio do crédito de investimento para a pecuária. Com a reformulação do projeto em 1978, em conjunto com o Banco Mundial, o pequeno produtor, assim como os alimentos básicos, especialmente milho e feijão, se tornaram o principal objeto do projeto, uma mudança refletida na distribuição do crédito para esse ano, ${ }^{11}$ quando pela primeira vez o crédito de custeio superou o de investimento com $\mathrm{Cr} \$$ 45.539.960 para o primeiro contra apenas Cr\$ 6.764.170 para este último.

Ao analisar as metas do período de cinco anos do projeto, ${ }^{12}$ tem-se um retrato claro das dimensões do projeto, bem como da sua orientação específica em termos de público-meta. Divididos em cinco subáreas e posteriormente reorganizados em três subáreas, de acordo com as Microrregiões Homogêneas citadas anteriormente, o projeto inclui 49 dos 69 municípios que fazem parte da bacia do rio Paraguaçu. Tomando estes 49 municípios e utilizando os cálculos da Unidade Técnica responsável pela execução do projeto, o público potencial (0-50 ha) compreende aproximadamente 60.000 pequenos produtores. ${ }^{13}$

Diz-se que o projeto deve beneficiar aproximadamente 17.000 pequenos produtores nos cinco anos com crédito e assistência técnica, que equivaleria a quase $30 \%$ do público potencial. Se verificarmos as projeções para os beneficiários do projeto no quinto ano, no entanto, torna-se claro que a cifra de 17.000 representa o total acumulado de beneficiários com repetição ao longo dos cinco anos. A meta anual especificada para o último ano do projeto é de 3.995 beneficiários, o que corresponde aos mais modestos $6,7 \%$ do público potencial.

Examinando-se a distribuição dos beneficiários propostos, de acordo com a área total do estabelecimento, fica claro que o critério utilizado foi o de manter uma proporção constante $(6,6 \%)$ para cada estrato, de 0 -10 ha, 10-50 ha e 50-100 ha, respectivamente. Surpreende a inclusão, e ainda mais

${ }^{11}$ Fonte: Desenvolvimento rural no Nordeste: a experiência do POLONORDESTE, Op. cit. As cifras citadas aqui para 1978, baseadas nos cálculos de serviço de extensão rural, são de fato superestimadas, como veremos mais tarde, embora as proporções entre custeio e investimento permaneçam válidas. Este estudo de Sampaio e outros oferece uma boa avaliação do projeto de um ponto de vista macro, mas não trata das transformações a nível da unidade produtora.

${ }^{12}$ Os dados nesta parte são baseadas nos cálculos para o Plano Plurianual elaborados em 1977 pela Unidade Técnica junto com a CEPA-Ba.

${ }^{13}$ Veja Resumo do PDRI: Paraguaçu, Unidade Técnica, 1981. 
a representação proporcional, deste último estrato, de 50-100 ha, já que o limite para os projetos agrícolas foi fixado em 50 ha. Pode ser, no entanto, que sua inclusão decorra de condições de especialmente baixa fertilidade encontradas em algumas regiões do projeto.

A ambiguidade desta distribuição aparentemente equitativa do público-meta emerge ao se constatar a distribuição prevista para o crédito. Considerando-se os dados para 1978, o estrato de 10-50 ha prevê crédito financiado para uma área (3.779 ha) aproximadamente $60 \%$ maior que a prevista para o estrato de $0-10$ ha (2.340 ha). Se somarmos a isso os 1.307 ha projetados para o estrato de 50-100 ha, concluímos que os produtores com até 10 ha se beneficiam de apenas $30 \%$ da área financiada, embora constituam $45 \%$ do público-meta potencial na área do projeto. ${ }^{14}$

Desta forma, a igualdade formal baseada na estrutura agrária existente só serve para reforçar os melhor situados entre os pequenos produtores.

A perspectiva para o estrato de $0-10$ ha piora ainda mais com a previsão de financiar a implantação de 12.655 ha de pastagens, dos quais 8.475 ha em estabelecimentos com mais de 100 ha. Dentro do projeto como um todo os pecuaristas, que constituem apenas $4 \%$ do público, recebem aproximadamente $12 \%$ do crédito total.

Na sua reformulação, então, o PDRI Paraguaçu tem uma clara orientação para o pequeno produtor. Esta orientação, no entanto, é limitada em termos de abrangência, por um lado, e seletiva na escolha de públicometa, por outro, o que tende a dar um peso desproporcional aos estabelecimentos maiores dentro do setor minifundista, orientação esta agravada ainda mais pela subestimativa da participação dos estabelecimentos de 0-10 ha dentro deste público.

\section{O POLONORDESTE e as principais tendências na região}

Nosso principal propósito neste Capítulo é analisar a forma pela qual a integração às estruturas do crédito oficial orientado modifica a dinâmica

\footnotetext{
${ }_{14}$ Muito provavelmente uma subestimação. Uma pesquisa na área contratada pelo PDRI indica que 59,5\% de todos os estabelecimentos na área têm menos de 10 ha, uma cifra que chega até $70 \%$ em uma das cinco sub-regiões do projeto. Cf. Pequenos produtores locais na bacia de Paraguaçu, Antônio da Silva Câmara e Solon Santana Fontes (mimeo, 1980, p. 23).
}

da produção de pequenos produtores no contexto concreto da inserção destes numa estrutura agrária específica.

Entretanto, antes de analisar os dados sobre esta questão, é importante situar o desenvolvimento do projeto no que se refere a outras tendências evidenciadas na região, bem como no que se refere aos outros segmentos do projeto que afetam diretamente o pequeno produtor enquanto unidade produtiva. ${ }^{15}$

\subsection{Crédito}

Se analisarmos a estrutura e a quantidade do crédito liberado pelo Banco do Brasil na área do projeto, descobrimos uma evolução relevante no triênio 1977-79.

Tabela 17 - Crédito rural 1977-79 (em milhões de cruzeiros); liberação de crédito pelas agências do Banco do Brasil na área do PDRI Paraguaçu, discriminado por

\begin{tabular}{c|c|c|c}
\multicolumn{4}{|c}{ lavoura e pecuária } \\
\hline Ano & Lavoura & Pecuária & Total \\
\hline 1977 & $\begin{array}{c}236.235 .000 \\
(48 \%)\end{array}$ & $\begin{array}{c}252.436 .000 \\
(52 \%)\end{array}$ & 488.751 .000 \\
\hline 1978 & $\begin{array}{c}425.953 .000 \\
(49 \%)\end{array}$ & $\begin{array}{c}438.441 .000 \\
(51 \%)\end{array}$ & 864.394 .000 \\
\hline 1979 & $\begin{array}{c}924.753 .000 \\
(56 \%)\end{array}$ & $\begin{array}{c}733.759 .000 \\
(44 \%)\end{array}$ & 658.512 .000 \\
\hline
\end{tabular}

Fonte: Banco Central do Brasil, adaptado dos dados da CEPA-Ba.

A redução na participação do crédito à pecuária é notável quando comparada com os $90 \%$ verificados em $1967 .{ }^{17}$ Entretanto, este parece ser resultado não da sua substituição pelo crédito do POLONORDESTE e sim o reflexo de restrições generalizadas para o crédito à pecuária nesse período, assim como de um incremento significativo do crédito para o café, o qual,

15 Não incluímos, portanto, uma avaliação dos projetos de educação e saúde, embora reconheçamos que estes elementos possam ter influência importante sobretudo a médio prazo para questões de produtividade de trabalho, utilização de trabalho infantil, êxodo rural, dependência em trabalho fora etc.

${ }^{16}$ O Banco do Brasil cortou para 80\% do crédito agrícola na Bahia em 1980.

${ }^{17}$ Veja acima, no início deste Capítulo. 
como foi mencionado anteriormente, vem experimentando uma expansão rápida na região. ${ }^{18}$

O crédito canalizado através do POLONORDESTE no mesmo período se mostra insignificante em termos globais, representando apenas $4 \%$ do total do crédito concedido. Apesar do notável incremento constante do crédito alocado ao público do POLONORDESTE na região do Paraguaçu (a estimativa preliminar para 1980 é de Cr\$125.560.000), a preponderância de linhas normais de crédito tende a levar à consolidação preferencial dos estabelecimentos médios e, especialmente, grandes na área. Nos três anos, 1977-79, as liberações de crédito eram apenas $\mathrm{Cr} \$ 17.862 .000, \mathrm{Cr} \$$ 24.493.000 e Cr\$ 68.260.000 respectivamente. ${ }^{19}$

\subsection{Comercialização / cooperativismo}

Como seria de esperar, baseado na caracterização da região apresentada anteriormente, as tentativas de consolidar um setor de pequenos produtores orientados para o mercado têm se defrontado com outros sérios obstáculos.

O padrão de uma agricultura basicamente de subsistência, com as vendas limitadas ao mercado local, retrato este confirmado por uma pesquisa recente na região, citada anteriormente, ${ }^{20}$ se reflete no estado precário das estradas vicinais que torna o acesso às pequenas propriedades extremamente difícil.

Além disso, a insignificância dos excedentes da produção agrícola destinados à comercialização reforça a tendência de a cooperativa na área identificar-se quase totalmente com os interesses dos pecuaristas. ${ }^{21} \mathrm{Na}$

\footnotetext{
${ }^{18}$ Como argumenta o trabalho de Sampaio e outros, $O p$. cit., o mais grave é que eles utilizam este argumento como uma crítica, que se fosse verdadeira, representaria um fortalecimento da posição de pequenos produtores (veja p. 441, Op. cit.)

${ }^{19}$ Dados da Unidade Técnica com base em fontes bancárias. Estes se chocam com as estimativas da EMATERBA, porém, provavelmente são mais confiáveis. Trataremos desta questão, mais tarde, neste Capítulo.

20 "A parte do excedente destinado ao mercado passa por um circuito comercial que normalmente não extrapola as fronteiras das subáreas onde foi produzido", p. 34, Pequenos produtores rurais (op. cit.).

${ }_{21}$ Veja as conclusões num trabalho anterior do autor: Avaliação de programas governamentais para produtores de baixa renda, CEPA-Ba, Salvador (escrito em 1978 e publicado em 1982)
}

verdade, das oito cooperativas existentes na região, apenas duas se mostravam ativas na linha de comercialização quando o PDRI foi iniciado, e estas trabalham com sisal e leite, produtos não incluídos no projeto.

O cooperativismo constitui o elo estratégico da orientação do PDRI, servindo como um canalizador efetivo para a integração dos pequenos produtores à rede de intervenções governamentais e do capital industrial e financeiro. O objetivo é que a cooperativa assuma a responsabilidade pela distribuição do crédito e assim livrar os bancos do risco, bem como criar uma estrutura independente para o disciplinamento do pequeno produtor em relação ao capital financeiro. Ademais, ao centralizar a comercialização e o fornecimento de insumos, a cooperativa reduz os custos da intervenção estatal e facilita a penetração dos insumos industrializados.

Na região do Paraguaçu, no entanto, esta estratégia parece ter sido dificultada em função da política governamental de trabalhar com cooperativas já existentes, neste caso, ou identificadas essencialmente com os interesses de pecuaristas, ou moribundas, ou as duas coisas. Segundo um relatório da Unidade Técnica,

em geral a atividade cooperativista estava num estágio apenas embrionário, com uma participação mínima de sócios nas atividades da Cooperativa, enquanto esta tinha quase nada a oferecer. A desorganização financeira e administrativa, a inexistência de qualquer infraestrutura para comercialização (armazéns, transporte etc.), a escassez de capital e a ausência de orientação efetiva por parte dos órgãos responsáveis por este serviço, foram alguns dos obstáculos detectados no diagnóstico original, servindo para explicar a fraqueza de atividade cooperativista que se resume essencialmente na venda de insumos e implementos agrícolas (Cooperativismo, Unidade Técnica).

Após três anos de intervenção, envolvendo assistência técnica financeira, pelo menos cinco das oito cooperativas haviam sido reestruturadas e colocadas em boas condições financeiras e administrativas. O número total de sócios havia aumentado em 40,1\% (de 5.312 para 7.447), o capital social havia crescido $86,7 \%$, e seis das cooperativas desenvolveram atividades de comercialização em 1979. Nos três anos entre 1978 e 1980, a comercialização de milho e feijão equivaleu a 20\%, $10 \%$ e $5 \%$ respectivamente da colheita do público do PDRI, conforme cálculos da EMATERBA. Durante estes anos a queda nas vendas de milho e feijão foi 
compensada, em parte, pela diversificação nos produtos comercializados (vide Tabela 18).

Tabela 18 - Cooperativismo: volume de produção comercializada por produto $1978-80^{22}$

\begin{tabular}{l|c|c|c}
\hline \multicolumn{4}{c}{1978} \\
\hline Cooperativas & Feijão & Farinha & Milho \\
\hline Serrinha & 11.975 & - & - \\
\hline Feira de Santana & 3.223 & - & - \\
\hline Castro Alves & 1.915 & - & - \\
\hline Ipirá & 9.280 & - & - \\
\hline Mundo Novo & - & - & - \\
\hline Rui Barbosa & - & - & - \\
\hline Itaeté & - & - & - \\
\hline Riachão do Jacuípe & - & - & - \\
\hline Total & 30.393 & - & - \\
\hline
\end{tabular}

\begin{tabular}{l|c|c|c|c}
\multicolumn{7}{c}{1979} \\
\hline Cooperativas & Feijão & Milho & Farinha & Alho \\
\hline Serrinha & 11.563 & - & - & - \\
\hline Feira de Santana & 1.290 & - & - & - \\
\hline Castro Alves & 745 & - & - & - \\
\hline Ipirá & 6490 & - & - & - \\
\hline Mundo Novo & 1.656 & - & - & - \\
\hline Rui Barbosa & 137 & - & - & - \\
\hline Itaeté & - & - & - & - \\
\hline Riachão do Jacuípe & - & - & - & - \\
\hline Total & 21.881 & - & - & - \\
\hline
\end{tabular}

\footnotetext{
${ }^{22}$ Todas as quantidades se referem a sacos de 60 quilos, exceto no caso do alho, que é medido em quilos. Compilado dos relatórios da Unidade Técnica.
}

1980

\begin{tabular}{l|c|c|c|c|c}
\hline Cooperativas & Feijão & Milho & Alho & Farinha & Mamona \\
\hline Serrinha & - & - & 738 & - & - \\
\hline $\begin{array}{l}\text { Feira de } \\
\text { Santana }\end{array}$ & - & 1207 & - & - & - \\
\hline Castro Alves & - & - & - & - & - \\
\hline Ipirá & 4.486 & - & 233 & - & - \\
\hline $\begin{array}{l}\text { Mundo } \\
\text { Novo }\end{array}$ & 1.926 & - & 1.220 & - & - \\
\hline Rui Barbosa & 416 & 500 & 11.888 & 1.100 & - \\
\hline Itaeté & - & 1.219 & 880 & - & 360 \\
\hline $\begin{array}{l}\text { Riachão do } \\
\text { Jacuípe }\end{array}$ & - & - & - & - & - \\
\hline Total & 6.828 & 1.926 & 14.959 & 1.100 & 360 \\
\hline
\end{tabular}

Os relatórios técnicos apresentam evidências conflitantes a respeito do impacto sobre o público do PDRI decorrente do fortalecimento da rede de cooperativas na área.

Noventa por cento de uma amostra aleatória composta de 33 produtores, sócios de três cooperativas, entrevistados em 1980 por pessoal da Unidade Técnica, segundo o mesmo relatório sobre Cooperativismo, eram pequenos produtores, de acordo com os critérios para inclusão no PDRI, e também recebiam crédito oficial de custeio. Dentre os entrevistados havia uma mudança significativa no sentido de vender seu produto diretamente à cooperativa em 1978 e 1979, de maneira que a cooperativa respondeu pela maioria das transações com feijão em 1979. Além disso, em cada ano os preços eram superiores ao preço mínimo do governo, quer na venda à cooperativa, quer a intermediários.

Contudo, estes resultados devem ser interpretados com cuidado, devido ao reduzido tamanho da amostra, com a maioria dos entrevistados pertencentes à cooperativa de Ipirá, a qual é sempre apontada nos relatórios da Unidade Técnica como a que tem maior participação de pequenos produtores.

Em contraste com esta avaliação otimista, o relatório da Unidade Técnica em 1980 sobre cooperativismo na área dá ênfase ao fato de que apenas $10 \%$ dos 1.049 sócios novos eram do público do POLONORDESTE. Outrossim, "poucos dos produtores que vendem suas colheitas à cooperativa 
são dos grupos de produtores do POLONORDESTE”. Reportava-se, além do mais, que as cooperativas compravam diretamente de comerciantes locais.

Assim, parece que, embora certas camadas do público, principalmente aquelas que residem nas circunvizinhanças das cooperativas, também se beneficiem, a principal tendência do fortalecimento de instituições, não exclusivamente voltadas para o público do POLONORDESTE, é beneficiar os comerciantes e os médios e grandes produtores na área.

Entretanto, enquanto existe tendência para o maior aproveitamento dos investimentos infraestruturais por parte das forças sociais dominantes na região, no caso da intervenção do PDRI ao nível de cooperativismo e comercialização, parece que os preços agora são fixados em níveis iguais ou superiores aos preços mínimos do governo. Como vimos no caso da amostra aleatória, os preços foram superiores ao mínimo, independente de a venda ser feita à cooperativa ou a intermediários. Além disso, técnicos visitando a área relatam que:

mesmo quando não vendem à cooperativa, os produtores conhecem os preços de garantia, e somente vendem, mesmo quando enfrentam os comerciantes tradicionais da região, ao preço de mercado vigente. $^{23}$

\subsection{Compra antecipada da produção (CAP)}

Com o propósito de compensar a fraqueza da estrutura cooperativista, o esquema governamental de compra antecipada da produção ${ }^{24}$ tem sido promovido de modo a atender produtores em áreas mais distantes.

Entretanto, até o momento seu significado tem sido extremamente limitado, alcançando como máximo $8 \%$ do público do POLONORDESTE, quando comparado com os dados sobre o número de produtores e a área atingida com assistência técnica. ${ }^{25}$

\footnotetext{
${ }^{23}$ Relatório Técnico Avaliação do segmento comercialização.
}

${ }^{24}$ Compra antecipada da produção. Sobre os efeitos contraditórios deste programa, veja A experiência em desenvolvimento rural integrado no Nordeste brasileiro, Yves Chaloult e outros, Rio Grande do Norte, 1980, onde se destaca o refortalecimento do latifúndio como resultado do estímulo a tipos de arrendamento.

${ }^{25}$ A COBAL tem a responsabilidade da execução deste programa.
Além disso, $88 \%$ do orçamento para 1981 foi concentrado na área de Feira de Santana.

Concebido como um programa especificamente dirigido aos nãoproprietários com dificuldade de acesso ao crédito oficial, através do financiamento da produção em troca da venda do produto ao preço mínimo do governo, verifica-se que em 1979 e 1980, respectivamente, $70 \%$ e $61 \%$ do seu público eram "proprietários". Além do mais, relatórios técnicos levantam dúvidas quanto à natureza do público e sugerem a existência de sérias distorções. ${ }^{26}$

Apesar dos esforços para envolver o público do PDRI em estruturas de comercialização que pelo menos garantam o preço mínimo do governo, aproximadamente $80 \%$ deste público, após cinco anos de intervenção, continua dentro da estrutura tradicional de comercialização. Conclui-se daí que, longe de eliminar o intermediário tradicional, é este, na forma do caminhoneiro, que tem a posição mais reforçada pelo aumento de produção na região.

Pode-se argumentar que pelo menos a intervenção do POLONORDESTE tem assegurado os preços mínimos do governo como ponto de referência para as transações. No entanto, é necessário observar que os preços de mercado para produtos básicos como milho e feijão têm sido superiores aos preços mínimos oficiais no período em questão. ${ }^{28}$

\subsection{Organização de comunidade}

Grande ênfase é dada à organização de base do público do POLONORDESTE, envolvendo grupos de produtores e associações comunitárias.

\footnotetext{
${ }^{26}$ Relatório trimestral, Op. cit.

27 "Caminhoneiros continuam sendo os mais importantes compradores na região contando para 30\% do total comercializado em 1978 e aumentando para 50\% em 1979, seguidos por vendedores nos mercados locais e donos de armazéns" (veja Pesquisa da Unidade Produtiva, Unidade Técnica, 1981, p. 58).

${ }^{28}$ Segundo os dados da CFP, os preços mínimos para feijão na safra 1979-80 que entraria em vigor em 02/07/79 eram Cr\$ 411,60 para um saco de $60 \mathrm{~kg}$. No mesmo mês o preço na região de Feira de Santana era de $\mathrm{Cr} \$ 800,00$ e continuou a aumentar até chegar em $\mathrm{Cr} \$$ $1.000,00 \mathrm{em}$ dezembro do mesmo ano, segundo os cálculos para preços ao produtor calculados pelo Sistema Nacional de Informação do Mercado Agrícola, 1980.
} 
A primeira vista, pelo menos, os resultados são apreciáveis: 456 grupos de produtores, 91 associações comunitárias e 42 grupos de pais e professores.

A pesquisa direta, entretanto, tende a confirmar o retrato de um público essencialmente atomizado:

Em primeiro lugar, a evidência indica que as concentrações a que os documentos do PDRI se referem precisam ser melhor examinadas e qualificadas. Do ponto de vista espacial, o levantamento mostra que, em cada subárea, aglomerações de produtores eram pequenas, poucas e distantes uma de outra. Foi mais comum encontrar pequenos estabelecimentos espalhados no meio de propriedades maiores... Outra indicação disto, revelada pelos técnicos do PDRI, é a frequente substituição de supostas concentrações de pequenos proprietários com novas áreas de pequenas aglomerações em decorrência de não encontrar aquelas na prática. ${ }^{29}$

De fato, embora estas organizações de base sejam promovidas ativamente pelos técnicos de campo, sua razão de ser é muito mais facilitar o trabalho das equipes vinculadas ao projeto e baratear o custo de sua operacionalização do que promover a organização independente dos pequenos produtores em questão. ${ }^{30}$ Neste sentido ê significativo notar que não existe nenhuma orientação para os sindicatos rurais por parte do projeto.

Um bom exemplo é o caso da assistência técnica, a qual, com uma média de 200 a 300 produtores por técnico, seria impossível se dependesse de visitas individuais às fazendas assistidas. Todos os produtores que fazem parte do programa são alocados automaticamente a grupos de produtores. $\mathrm{Na}$ prática, no entanto, a mobilização destes grupos tende a ser muito limitada, além de voltada principalmente para a necessidade de promover e supervisionar as liberações do crédito oficial.

Esta orientação grupal prevalece também no trabalho social executado pelo pessoal da EMATERBA, e, como no caso anterior, constitui

\footnotetext{
${ }^{29}$ Pequenos produtores rurais na bacia de Paraguaçu, Op. cit.

30 "Recomendações: a extensão rural precisa utilizar uma estratégia melhor para racionalizar seu trabalho e alcançar resultados melhores, a começar pela localização de concentrações de pequenos produtores e a formação de grupos de produtores", Relatório do Subprojeto Assistência Técnica, 1978.
}

essencialmente um mecanismo para baratear os custos destes serviços (e na verdade do projeto global) através da promoção do envolvimento da comunidade, aumentando o público assistido por assistente social, bem como através da promoção de soluções do tipo "self-help" para as questões de habitação, saneamento, saúde e nutrição.

Mesmo assim, estas atividades são mais dominadas pela ideologia da organização da comunidade, e há esforços para preservar e ampliar as formas solidárias de ação - desde as práticas tradicionais do trabalho coletivo (mutirão) até a compra de equipamentos e a venda de produtos em comum. Uma indicação deste trabalho é apresentada no relatório de assistência social na região de Itaberaba em 1980. Verifica-se a partir de seus dados que apenas 15 dos 173 grupos de produtores nesta sub-região se envolveram na venda em comum dos seus produtos agrícolas.

$\mathrm{Na}$ verdade, como veremos mais claramente no caso de Irecê, apesar destes esforços a favor da organização comunitária, o principal efeito do POLONORDESTE é atomizar o pequeno produtor ainda mais, condicionar seus padrões de cooperação crescentemente de acordo com as exigências da lei do valor através do estímulo de um processo generalizado de monetarização. No caso de Paraguaçu uma queda nas formas de ajuda mútua foi detectada naquelas áreas mais integradas à área de crédito oficial e insumos modernos. ${ }^{31}$ Processos semelhantes serão analisados nos casos de Irecê e do PEC/Serra do Ramalho.

\subsection{Regularização de terras}

A outra área de relevância direta para os pequenos produtores é a questão de regularização fundiária. Dentro do projeto há um subprojeto voltado para a emissão de títulos, um aspecto especialmente promovido pelo Banco Mundial. A meta estabelecida para os primeiros cinco anos do projeto foi a entrega de 15.000 títulos, mas até o final de 1980 o número efetivamente entregue era de 2.376. Mesmo assim, este número representa mais de $55 \%$ do público que recebe crédito dentro do projeto, embora seja apenas $5 \%$ do público potencial na região.

Embora haja muita crítica à operação da titulação de terras, o direcionamento e a urgência desta crítica, expressa exclusivamente em

${ }^{31}$ Pesquisa da Unidade Produtiva, op. cit., p. 66. 
termos da demora burocrática, reflete a esperança atribuída a esta orientação, como instrumento eficaz contra a grilagem, o que permite a estabilização do público de pequenos produtores na área. ${ }^{32}$

Este ponto de vista, no entanto, ignora dois fatores cruciais. O tamanho de um bom número de minifúndios é insuficiente para garantir a reprodução do pequeno produtor e sua família. $\mathrm{O}$ trabalho assalariado sazonal e o arrendamento de terra pertencente às propriedades maiores passaram a ser portanto um recurso que constitui uma parte da reprodução do público do PDRI.

A entrega de títulos, por isso, não eliminará este tipo de dependência do trabalho fora da propriedade que decorre, fundamentalmente, da insuficiência de sua terra como base para a reprodução do produtor. $\mathrm{Na}$ prática, a política de titulação, que beneficia os grandes produtores de forma igual, bem poderá levar à redução das práticas tradicionais de arrendamento e ocupação, já que estes podem ser vistos como ameaça à aquisição do título às terras em questão. Isto, por sua vez, exacerbaria a posição destes pequenos produtores.

Este resultado representaria uma ameaça especial aos ocupantes, que formam uma parcela significativa do público potencial do PDRI. Embora seja prevista pelo projeto a incorporação de não-proprietários, ${ }^{34}$ há uma tendência a subestimar seu peso na área e a concentrar os recursos do projeto nos produtores que são proprietários. Uma pesquisa na área revelou uma relação muito variada entre os proprietários e os não-proprietários nas diferentes subáreas, verificando-se uma média geral de $38 \%$ nãoproprietários. ${ }^{35}$ A entrega de títulos de terra, portanto, representa a exclusão de mais de um em três do público potencial do PDRI aos direitos sobre a terra.

\footnotetext{
${ }^{32}$ Atualmente esta política constitui o elemento principal das intervenções federais sobre a questão do pequeno produtor, com uma meta de 300.000 títulos para 1981.

${ }^{33}$ Uma proposta que transformaria a ocupação pacífica durante pelo menos cinco anos em direito de propriedade está sendo discutido a nível federal.

34 Já vimos isto no caso da comercialização através da CAP: a questão do crédito será analisada neste contexto, mais tarde no Capítulo Seis.

${ }^{35}$ Nas cinco sub-regiões, a porcentagem não-proprietários era de $12,5 \% ; 75 \% ; 47,1 \% ; 44,8 \%$ e $12,5 \%$, segundo a pesquisa Pequenos produtores, citada acima.
}

Um esquema para um fundo de crédito para a compra de terras dirigido aos não-proprietários já foi incluído no PDRI, mas até o momento tem sido praticamente inoperante, e é difícil imaginar como os pequenos produtores possam pagar estes empréstimos, que são calculados à base dos atuais preços de mercado.

\subsection{Conclusão}

Nesta breve análise fica claro que o PDRI Paraguaçu não tem conseguido transformar as estruturas agrárias e de comercialização na região e que a integração dos pequenos produtores ao capital financeiro não tem levado ao fechamento do circuito em termos de modernos capitais comercial e agroindustrial. O capital mercantil tradicional continua dominando o mercado e na verdade tem se fortalecido com o aumento de produção na área.

Pesquisas recentes no Brasil têm reagido contra uma orientação exclusiva acerca do processo produtivo (estimulados especialmente pelos debates sobre a natureza capitalista ou não-capitalista de diferentes formas de parceria), ${ }^{36}$ insistindo que a dinâmica interna do processo produtivo depende da posição deste na esfera da circulação. ${ }^{37}$

Este ponto de vista, no entanto, precisa ser complementado no caso do público do POLONORDESTE. Embora seja correto que o capital mercantil continue dominando o processo de comercialização, não mais combina esta posição com a de capital usuário, como veremos mais adiante na nossa explicação pormenorizada.

A integração à estrutura do crédito oficial representa, a nosso ver uma ruptura com o tradicional círculo fechado do capital mercantil em dois sentidos distintos. As políticas do seguro, da prorrogação do débito e até de anistia para os mutuários do crédito, ${ }^{38}$ servem para proteger o produtor

${ }^{36}$ A fonte clássica deste enfoque se encontra nos debates no início dos anos 60 sobre "capitalismo x feudalismo", sobretudo nas contribuições de Caio Prado Jr., A questão agrária no Brasil e A. P. Guimarães, Quatro séculos de latifúndio. Para uma contribuição mais recente, veja Parceria e capitalismo, M. R. G. Loureiro, 1977.

${ }^{37}$ Veja Lavradores e pequenos produtores de cana, Delma Pessanha Neves (Zahar, 1981).

${ }^{38}$ O PROAGRo não cobre o valor da produção, mas no caso de uma frustração de safra dispensa o pagamento do crédito. A extensão deste esquema ao público do POLONORDESTE tem sido dificultado pelo fato que exige como precondição que $15 \%$ dos custos sejam para 
contra o risco da produção e a ameaça de endividamento que isto tradicionalmente implica. Em segundo lugar, o crédito de investimento permite um processo de tecnificação independente de um excedente acumulado.

Argumentamos, então, e examinamos esta questão com mais detalhe, adiante, que pelo menos no curto prazo o impacto de integração ao crédito oficial gera uma relativa independência com relação às redes de comercialização, permitindo uma transformação no processo de produção mesmo quando o capital mercantil controla a esfera de circulação. Isto é especialmente correto para o período atual, quando os preços mínimos de garantia do governo têm sido, por muitos anos, inferiores aos preços de mercado para produtos básicos.

\section{Análise critica das pesquisas de campo existentes}

\subsection{Pesquisa do Banco do Brasil}

Nossa primeira fonte para examinar esta questão é a pesquisa do Banco do Brasil avaliando o impacto da assistência técnica e do crédito bancário para três projetos do POLONORDESTE - serra do Baturité, Agreste Meridional e a bacia do Paraguaçu na Bahia. ${ }^{39}$

Infelizmente os anexos explicando a metodologia da pesquisa e os critérios para a determinação da amostra não estão incluídos no Relatório.

Para a região de Paraguaçu, 70 pequenos produtores foram entrevistados, dos quais 55 (79\%) são classificados como proprietários, 12 (17\%) como arrendatários, 1 como parceiro, e 2 como posseiros. Esta proporção portanto exagera a categoria dos proprietários, dado que as outras categorias, como vimos acima, formam $38 \%$ do público potencial. No entanto dados sobre crédito conseguidos das agências do Banco do Brasil na região pela Unidade Técnica do POLONORDESTE indicam que para os dois anos 1978/1979, 3.025 (78\%) dos 4.273 beneficiados (com repetição)

insumos modernos - um exemplo claro do POLONORDESTE como política de modernização induzida. Em 1980-81 houve uma anistia para todos os empréstimos de crédito por causa da quebra generalizada da safra. Sobre o PROAGRO veja Notas sobre a política de crédito rural, L. C. Guedes Pinto, Campinas, 1980.

39 Projeto de crédito rural do POLONORDESTE, Banco do Brasil, Brasília. Este Relatório apresenta apenas as Tabelas da Pesquisa sem desenvolver uma interpretação dos dados. eram proprietários. As proporções portanto não diferem, embora o pequeno número da amostra do Banco do Brasil pode ter resultado num exagero do peso dos proprietários.

$62 \%$ destes proprietários tinham menos de 10 ha, subindo para $92 \%$ no caso dos arrendatários. Isto choca com as estimativas da Unidade Técnica de que apenas $37 \%$ dos beneficiários eram da faixa 0-10 nos anos $1978 / 1979 .{ }^{40}$ Em relação ao tamanho das propriedades, portanto, a pesquisa do Banco vai refletir desproporcionalmente as condições nas propriedades menores. De fato, na pesquisa apenas $12 \%$ dos proprietários cultivam mais de 4 ha, enquanto com uma área média de propriedade menor, 33\% dos arrendatários cultivam mais de 4 ha. $^{41}$

Outro fator limitante para uma pesquisa que pretende avaliar o impacto da assistência técnica e crédito, é a alta porcentagem dos entrevistados que estavam utilizando crédito pela primeira vez até $50 \%$. Mais ainda, no caso dos proprietários, 24\% receberam apenas assistência técnica, deixando que somente $30 \%$ da amostra representasse produtores beneficiados com o crédito por mais de uma safra. Destes porém a grande maioria $(80 \%)$ tem experiência de crédito oficial exclusivamente através do programa do POLONORDESTE, e forma portanto um público bom para o exame dos efeitos específicos de crédito do POLONORDESTE.

A primeira informação desta pesquisa relevante para nossa investigação diz respeito ao grau em que o crédito oficial substitui outros tipos de empréstimos. Numa resposta múltipla sobre fontes de crédito $76 \%$ dos proprietários e $69 \%$ dos arrendatários indicaram o Banco, com amigos e parentes contando para o restante, com a participação do latifundiário, da bodega e do caminhoneiro sendo insignificante.

Fontes outras que não o Banco, aparecem aqui como numericamente de pouca relevância e a figura do intermediário está totalmente ausente. Se acrescentarmos a isto os dados sobre o valor deste crédito, o peso do crédito bancário em relação a todas as outras fontes fica claro tanto no caso dos proprietários como no dos arrendatários.

\footnotetext{
${ }^{40}$ Compare estes números a $48 \%$ destinados a categoria de $0-10$ ha, durante os cinco anos do programa.

${ }^{41}$ A proporção maior de área cultivada no caso dos arrendatários expressa a estreita relação entre arrendamento e planos de produção.
} 
Embora os montantes absolutos sejam maiores, no caso dos outros dois projetos as proporções são similares com a diferença de que, na região de Baturité, empréstimos por parte dos bodegueiros adquirem maior peso. Mas ainda neste caso, apenas $28 \%$ destes empréstimos são maiores de $\mathrm{Cr} \$$ 10.000 , contra $72 \%$ no caso do crédito bancário.

No que toca ao uso de crédito, $77 \%$ dos proprietários e $71 \%$ dos arrendatários citam manutenção da família e custeio, com 19\% e 21\% respectivamente indicando os itens de investimentos. Esta pequena proporção dedicada ao crédito de investimento contrasta com as duas outras regiões investigadas onde os itens para investimento contam para $40 \%$ e $49 \%$ no caso de proprietários e $54 \%$ e $30 \%$ para arrendatários.

Nestas duas últimas áreas a proporção dos entrevistados com três ou mais anos de experiência com crédito bancário é mais alta $15 \%$ e $17 \%$ contra $10 \%$ no caso de Paraguaçu. Uma explicação a mais pode ser a pequena área cultivada no caso do público de Paraguaçu, onde apenas 13\% utilizam mais de 4 ha, contra $69 \%$ e $32 \%$ no caso dos proprietários nas duas outras áreas.

$89 \%$ dos proprietários e $100 \%$ dos arrendatários acharam que os serviços de extensão rural tinha melhorado suas condições de produção, e $57 \%$ dos proprietários e 50\% dos arrendatários aumentaram sua área cultivada depois de entrar no POLONORDESTE. (É preciso lembrar aqui que $50 \%$ do público de Paraguaçu estavam utilizando crédito oficial pela primeira vez.)

As respostas à pergunta se o uso da mão de obra ${ }^{42}$ teria aumentado como resultado de crédito e assistência técnica foram ambíguas, com $47 \%$ dos proprietários respondendo afirmativamente contra $83 \%$ no caso dos arrendatários. Contudo, como notamos acima, os arrendatários na região de Paraguaçu cultivaram áreas maiores, sendo que 33\% cultivaram mais de 4 ha, contra $13 \%$ no caso dos proprietários.

As respostas sobre o impacto de assistência técnica ajudaram a esclarecer esta questão. $76 \%$ dos proprietários e 100\% dos arrendatários afirmam que a influência de assistência técnica tinha levado a modificações nos seus métodos de produção.

\footnotetext{
${ }^{42}$ Não há discriminação aqui entre trabalho familiar e contratado, e nem sequer este assunto
} é referido na pesquisa.
É interessante notar que aqui os arrendatários mostram uma receptividade maior do que os proprietários. O que é mais significativo porém é que os elementos mais adotados são os que implicam maior utilização de mão de obra, tratos culturais, técnicas de plantio e espaçamento. Os itens menos adotados eram os que envolviam custos monetários (implementos modernos, fertilizantes químicos), com a exceção de inseticidas e sementes melhoradas que têm um impacto mais imediato sobre a produtividade. No entanto, é notável que no caso dos arrendatários cultivando uma área maior, existiu uma receptividade consideravelmente maior ao uso de implementos modernos poupadores de mão de obra.

Parece, portanto, que numa primeira fase o impacto da assistência técnica é de aumentar a intensidade de trabalho por unidade cultivada ao tempo em que o crédito leva a um aumento na área total cultivada.

Estas tendências, porém, não modificaram significativamente o grau de dependência em relação a mão de obra fora da propriedade, possivelmente como resultado das pequenas áreas cultivadas, devido ao fato que apenas $30 \%$ da amostra tenha sido integrada no programa por mais de uma safra. $24 \%$ e $25 \%$ respectivamente afirmaram que depois da incorporação no POLONORDESTE desistiram de trabalhar fora da roça. Nas outras duas áreas a porcentagem era maior, marginalmente no caso de Baturité - 26\% -, mais no Agreste meridional onde chega a $45 \%$ dos proprietários e $61 \%$ dos arrendatários; nestas regiões, como notamos acima, a área média cultivada era bem maior. ${ }^{43}$

Se o Banco conseguiu deslocar o capital mercantil como supridor de crédito, este último mantinha sua posição dentro do circuito de comercialização como a Tabela seguinte indica:

\begin{tabular}{l|c|c}
\multicolumn{3}{c}{ Tabela 19 - Locais de venda da produção. } \\
\hline Pontos de venda & Proprietários (\%) & Arrendatários (\%) \\
\hline Na roça & 39 & 50 \\
\hline Bodega & 13 & 17 \\
\hline Latifundiário & 0 & 0 \\
\hline Vizinho & 11 & 0 \\
\hline Mercado & 20 & 0 \\
\hline
\end{tabular}

${ }^{43}$ Apenas $8 \%$ dos arrendatários em Baturité deixou de trabalhar fora da roça, mas neste caso existe uma área média cultivada bem menor, com apenas $25 \%$ acima de 4 ha. 


\begin{tabular}{l|c|c}
\hline Cooperativa & 10 & 0 \\
\hline Mercado do produtor & 0 & 0 \\
\hline Caminhoneiro & 0 & 25 \\
\hline Outros & 7 & 0 \\
\hline Total & 100 & 100 \\
\hline \multicolumn{2}{c}{ Fonte: Op. cit., p. 13. }
\end{tabular}

Op. cit., p. 13

Esta Tabela (19) é pouco clara porque confunde o local de venda e a pessoa a quem o produto é vendido. Assim, por exemplo, 39\% (no caso dos proprietários) vendem seus produtos na própria roça, e nenhum declara venda ao caminhoneiro. Dado que todas as opções são apresentadas, é difícil imaginar quem mais poderia ser o beneficiário destas vendas. ${ }^{44}$ Pode ser que a porcentagem dada para vendas na roça devesse ser distribuída entre todas as outras categorias, menos o caso de venda direta no mercado local. De qualquer forma, fica claro nos dados que apenas $20 \%$ vendem diretamente ao mercado, e uma porcentagem bem menor comercializa através da Cooperativa. $70 \%$ no caso dos proprietários e $100 \%$ dos arrendatários utilizam canais tradicionais para a venda dos seus produtos.

E interessante notar que, no caso dos arrendatários, o latifundiário aparentemente não se envolve na compra do produto, refletindo o caráter de subsistência desta produção na região. Como veremos mais tarde, a importância do arrendatário para os pecuaristas de Paraguaçu, é mais no sentido de oferecer um mecanismo para a criação de pastagem a custos nulos. A bodega conta para uma proporção significativa destas vendas, embora os dados não indiquem que isto seja o resultado de dívidas anteriores. Igualmente importante parece ser a figura do "vizinho" como intermediário, uma tendência comum também na região de Baturité (17\% e $13 \%$ respectivamente), o que sugere que, com o aumento na produção sobretudo em áreas tradicionais de comercialização pouco desenvolvidas, o POLONORDESTE está criando as condições para o surgimento do produtor/comerciante. Uma tendência neste sentido a respeito de vendas na Cooperativa foi notada também no Relatório da Unidade Técnica sobre Comercialização:

\footnotetext{
${ }^{44}$ A ausência aqui do caminhoneiro não pode ser explicada apenas como consequência da natureza tradicional do comércio, porque $25 \%$ dos arrendatários a ele se referem como comprador. No entanto, é provável que este fato tenha influência aqui, sendo coerente também com a importância do armazém e o vizinho como intermediários.
}

os proprietários mais astutos colecionam os produtos dos vizinhos e os entregam à Cooperativa no seu nome, atuando portanto também como intermediário.

Infelizmente na questão sobre fontes de financiamento, a figura do "vizinho" não está explicitamente incluída, e assim é difícil dizer se sua presença a nível de comercialização implica endividamento por parte do vendedor. Contudo, a pouca importância de todas as formas de crédito nãobancário levaria a rejeitar esta hipótese.

De qualquer maneira a preponderância de formas tradicionais de capital mercantil no processo de comercialização fica bastante clara, e a pequena proporção absorvida pela cooperativa vai também de encontro aos nossos cálculos anteriores.

Em relação à época de venda encontramos uma situação aparentemente paradoxal em que a região de Paraguaçu, que em média tem a menor área cultivada, menor renda, e resultados menos positivos no que toca à produtividade, é a que mais tempo guarda sua produção depois da colheita. ${ }^{45}$ Nas outras duas regiões $60 \%$ e $67 \%$ dos proprietários vendem na época da colheita, contra $34 \%$ do público de Paraguaçu.

É provável, porém, que esta capacidade de reter o produto da safra decorra do nível pouco mercantil da produção, no caso de Paraguaçu, e também um menor compromisso ao nível de empréstimos bancários. Apenas $41 \%$ dos empréstimos superam Cr\$10.000, contra $72 \%$ e $80 \%$ nas duas outras regiões.

Em conclusão, podemos dizer que o capital mercantil foi efetivamente deslocado pelo crédito oficial do POLONORDESTE para o financiamento da produção. $\mathrm{O}$ impacto combinado de assistência técnica e de crédito tende para um aumento absoluto na quantidade de trabalho despendido (aumentos na área cultivada) para uma intensificação de trabalho por unidade cultivada como resultado da adoção de novas práticas, e para a utilização de crédito de investimento, menor no caso de Paraguaçu,

${ }^{45}$ A renda média para proprietários em Paraguaçu, era de Cr\$11.000, contra $\mathrm{Cr} \$ 72.000$, em Baturité e Cr\$ 42.000, no Agreste Meridional. Para arrendatários a cifra correspondente era de Cr\$ 16.000, no caso de Paraguaçu, contra Cr\$ 52.000, em Baturité e Cr\$ 50.000 no Agreste. Além disso, apenas $29 \%$ dos proprietários em Paraguaçu mostraram um aumento na produção, contra $77 \%$ em Baturité e $56 \%$ no Agreste. Para arrendatários, a cifra aumenta para 55\% em Paraguaçu, contra 69\% em Baturité e $80 \%$ no Agreste. 
como mecanismo para aumentar a produtividade de trabalho (compra de equipamentos modernos). Ao mesmo tempo um em cada quatro produtores desistiu de trabalhar fora da roça, como consequência de inserção no POLONORDESTE.

Estes resultados são ainda mais importantes se levarmos em conta o caráter tradicional de subsistência da região, as reduzidas áreas cultivadas pelo público utilizando crédito, e o fato de que a maioria do público só tinha um ano de experiência com o programa.

Por outro lado, o capital mercantil se mantém e se fortalece a nível de comercialização, até criando figuras novas como o "vizinho" intermediário.

Infelizmente, porém, o impacto desta mudança para a transformação das relações de produção dentro da unidade familiar não pode ser analisado com base nos dados desta pesquisa.

\subsection{Pesquisa de campo da Unidade Técnica}

Uma pesquisa feita em 1980 pela equipe de avaliação da Unidade Técnica do POLONORDESTE de Paraguaçu, destinava-se precisamente a cobrir esta lacuna como indica o título do seu Relatório, Pesquisa da Unidade Produtiva. ${ }^{46}$

Uma amostra de 10\% do público utilizando crédito em 1978 foi elaborada levando em conta o tamanho da propriedade e a sua localização, favorecendo aqueles municípios onde os serviços do POLONORDESTE estavam mais presentes.

Dos 171 incluídos na amostra, 88\% tinham utilizado o crédito do POLONORDESTE, pelo menos durante duas safras, ${ }^{47}$ oferecendo, portanto, uma base mais firme para avaliar o impacto da inserção no crédito oficial do que no caso da pesquisa do Banco do Brasil. Uma segunda amostra baseada no público do POLONORDESTE que não utilizou crédito, e calculado em $50 \%$ da primeira amostra, também foi elaborada. Contudo, a dificuldade em localizar produtores participando nos serviços do POLONORDESTE, mas

\footnotetext{
${ }^{46}$ Esta pesquisa foi feita a pedido do Banco Mundial, como parte do seu compromisso de cobrir um terço dos custos do projeto.

${ }^{47}$ Isto não está explicitado na parte sobre "Metodologia e Definição da Amostra", mas pode ser inferido da referência a 152 produtores recebendo crédito em 1979 (veja p. 34).
}

sem utilizar crédito, reduziu esta amostra de 86 para 59. Finalmente, em cada uma das áreas onde havia o público do POLONORDESTE, um produtor foi selecionado, que embora sendo parte do público potencial do POLONORDESTE, não estava envolvido em nenhum dos seus serviços; um total de 40 produtores obedecendo a este perfil foi selecionado. No caso das duas primeiras amostras, o mesmo questionário formal foi utilizado, enquanto, para o terceiro grupo, foram feitas entrevistas abertas.

Esta pesquisa, como veremos, confirmam as duas conclusões básicas das investigações do Banco do Brasil - a predominância absoluta do crédito oficial e a manutenção de formas tradicionais de comercialização.

Apenas $12 \%$ daqueles que utilizam crédito (18 produtores), também recorreram a empréstimos não-bancários, a maioria deles sendo proprietários. Analisando o caso destes últimos, o valor médio dos empréstimos somou menos da metade da média dos empréstimos bancários. Considerando como um todo o público que utilizou o crédito, os empréstimos não oficiais contaram menos de $6 \%$ do total. Infelizmente, o questionário não inclui dados sobre a origem destes empréstimos.

No que tange à comercialização, embora não dê tabelas a respeito, $\mathrm{o}$ relatório conclui:

Caminhoneiros continuam sendo os principais compradores na região respondendo por $30 \%$ do valor global da produção comercializada em 1978, e aumentando esta para 50\% em 1979. Depois dos caminhoneiros vêm comerciantes locais e os donos de armazéns. ${ }^{48}$

Mas se compararmos esta conclusão com os dados relevantes do questionário, vários problemas surgem. No caso da pesquisa do Banco do Brasil, notamos a confusão criada ao confundir local de venda e tipo de comprador. Na pesquisa da Unidade Técnica encontramos os itens "Venda na Roça" e "Caminhoneiro" também tratados como sendo a mesma coisa. Estes dados, portanto, não confirmam necessariamente a predominância da figura do caminhoneiro. Mais importante, talvez, é o fato de canais oficiais de comercialização (cooperativa, COBAL) não estarem incluídos como opções na formulação da pergunta. Outro problema decorre da confusão no Relatório entre "comerciantes locais" e vendas feitas diretamente pelo

${ }^{48}$ A tradução, aqui, é do inglês e não do texto original, como para a maioria das citações de textos originalmente em português. 
produtor no mercado local. E, finalmente, embora a figura do latifundiário esteja incluída na pergunta, não há referências no Relatório de sua importância para a comercialização. ${ }^{49}$ No entanto, se canais oficiais tivessem importância, é provável que estivessem refletidos no item "outros". Apesar destas ressalvas, a predominância de capital mercantil tradicional na área de comercialização parece ser uma conclusão segura.

Em contraste com a pesquisa do Banco do Brasil, o Relatório conclui que vendas "ainda predominam imediatamente depois da safra" $(O p$. cit., p. 58). Os dados incluídos mostram porém que $30 \%$ tradicionalmente guardavam sua produção, aumentando esse percentual para $38 \%$ depois de entrar no POLONORDESTE. ${ }^{50}$ Além disso, $16 \%$ declararam que utilizaram depósitos ou armazéns como resultado do programa.

A orientação básica da pesquisa, contudo, é examinar a transformação da unidade produtora como consequência da inserção no POLONORDESTE, utilizando "crédito oficial" como a variável principal, segundo o Relatório:

a hipótese é que o uso do crédito oficial junto com os outros serviços que este último promove, serve para capitalizar os pequenos produtores essencialmente através de um aumento no emprego regular de mão de obra assalariada (Op. cit., p. 15).

O conceito de "capitalização" no contexto da pequena produção é definido como a "generalização da produção e consumo de mercadorias, e principalmente o emprego de trabalho assalariado por parte do pequeno produtor" (Op. cit., p. 14).

A capitalização é explicitamente contraposta à tecnificação ou aumentos no patrimônio de produtores ${ }^{51}$ e vista como um processo de transformação do pequeno produtor em patrão:

Se pudéssemos reduzir o sentido de capitalização a uma só palavra, diríamos que é "apatronamento" de pequeno produtor, utilizando a

\footnotetext{
${ }^{49}$ O item "vizinho" está também incluído mas não mencionado no Relatório.

${ }^{50}$ Embora não fique claro no texto, interpreto que as cifras se referem aqui ao total dos produtores usuários ou não de crédito.

11 "Mas não devemos confundir capitalização com tecnificação e tampouco com a formação de um patrimônio por parte do camponês". (Op. cit., p. 4).
}

expressão de um trabalhador rural referindo-se a um líder sindical (Op. cit., p. 5).

A contratação regular é interpretada, portanto, como representando uma transformação qualitativa nas relações sociais:

O hábito de consumir mão de obra regularmente [cada ano] e não apenas eventualmente transforma o camponês num patrão e portanto num capitalista, o dono de meios da produção transformados em capital (Op. cit., p. 60).

Em primeiro lugar examinamos os dados apresentados para defender o argumento de que o crédito cria as condições para uma ruptura qualitativa, transformando o que anteriormente era uma unidade produtiva na base de trabalho familiar numa dependência regular e não apenas eventual em mão de obra assalariada.

Dois elementos estão em questão aqui. O primeiro diz respeito aos dados sobre o emprego de mão de obra antes e depois da incorporação no POLONORDESTE, discriminado em função de uso ou não do crédito, e o segundo a condição do produtor, conforme resumidos na Tabela 20. 


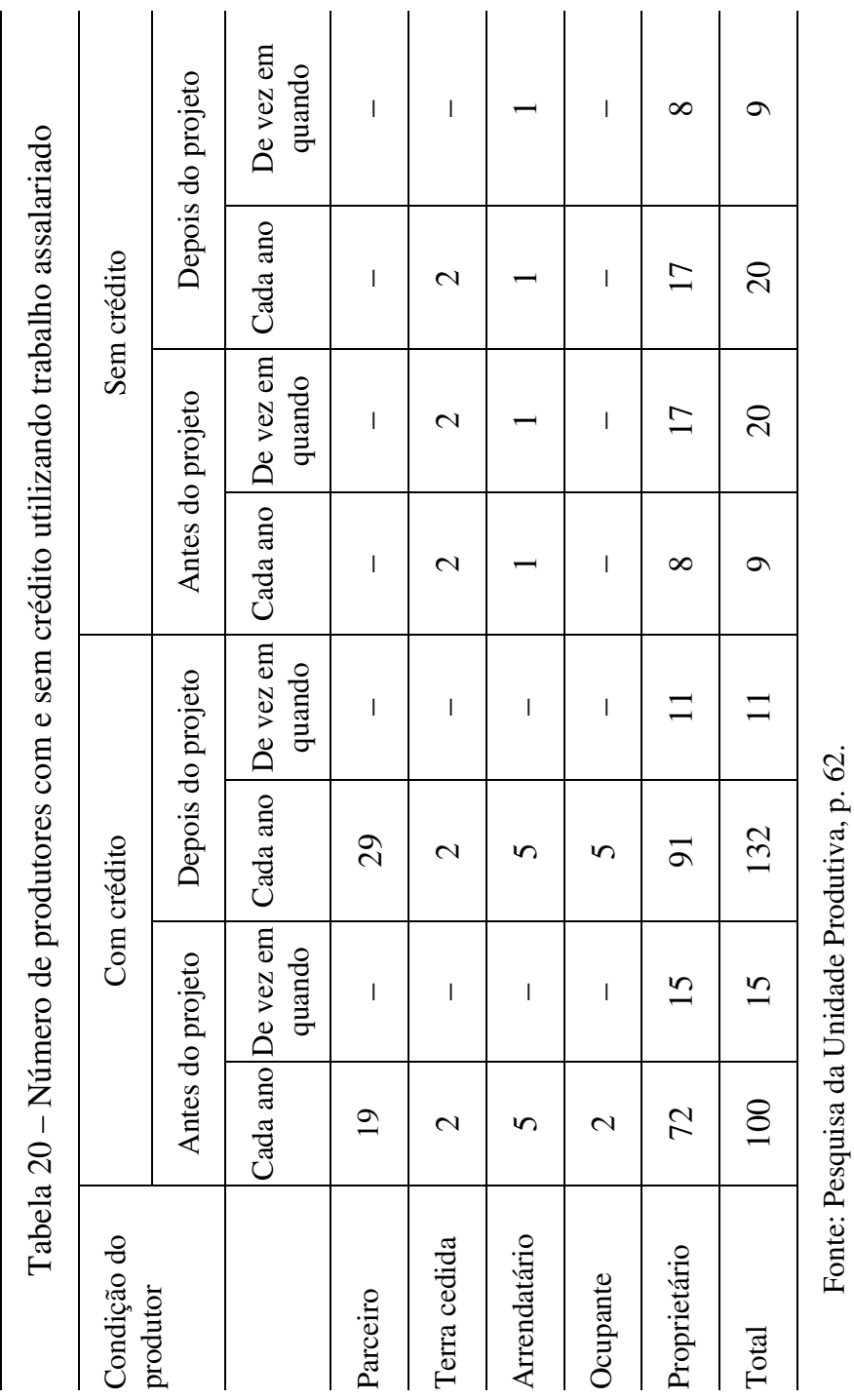

O que se nota, imediatamente, é que a maioria dos beneficiários do crédito no programa já empregavam mão de obra cada ano antes de entrar no PolONORDESTE (58\%). ${ }^{52}$ Mesmo reconhecendo que 37 destes já se beneficiaram do crédito, antes de entrar no projeto, ainda assim 63 (47\%) dos produtores empregavam mão de obra "regularmente" 53 antes de entrar nas estruturas do crédito oficial.

Ao mesmo tempo, 32 dos 81 beneficiados do crédito que não usavam mão de obra regularmente agora começavam a fazê-lo, e não houve aumento no caso daqueles que não utilizavam crédito. Neste sentido os dados indicam que o crédito aumenta as condições para o emprego da mão de obra. Mas o fato de quase a metade do público ter utilizado mão de obra a cada ano antes de entrar no projeto sem a ajuda de crédito, deve sugerir cautela na caracterização deste fenômeno. Apesar disto o Relatório conclui que

a pesquisa demonstrou que 100 produtores já empregaram mão de obra regularmente. $\mathrm{O}$ projeto, portanto, converteu 32 pequenos produtores em novos patrões, empregando outros pequenos produtores, ou da região do programa ou de fora, numa maneira regular, como consequência, acima de tudo, das facilidades de crédito rural (Op. cit., p. 60)

Com base neste enfoque, porém, dever-se-ia ter concluído que a maioria do público do POLONORDESTE que utilizava crédito já era capitalista antes de entrar no programa, e que o crédito, portanto, se coloca apenas como um dos fatores, entre outros, que contribuem para promover esta tendência.

A sombra do debate clássico que identifica a utilização regular de mão de obra assalariada com a existência da empresa capitalista rural, e que analisamos no Capítulo 2, pesa muito em toda esta interpretação da Unidade Técnica.

Antes de examinar com mais detalhe a natureza deste trabalho assalariado, devemos considerar um segundo grupo de dados, destacando o crédito como o elemento decisivo no emprego regular de mão de obra

${ }^{52}$ Op. cit., p. 39.

${ }^{53}$ Discutiremos adiante até que ponto contratação de mão de obra a cada ano pode ser vista como emprego "regular" de assalariados. 
assalariada. Em resposta a uma pergunta sobre o item de mais dispêndio individual em relação ao crédito, $55 \%$ indicaram salários, contra $16 \%$ para a manutenção da família, $15 \%$ aluguel de trator, $12 \%$ sementes, e $2 \%$ melhoramentos, apontando portanto para uma ligação estreita entre crédito e o emprego de mão de obra assalariada.

O que surpreende, porém, é a baixa porcentagem, 16\%, indicando a manutenção da família. Pode-se imaginar que a renda da safra anterior tenha funcionado como fonte desta manutenção. Mas os dados desta mesma pesquisa mostram que a renda média ( $\mathrm{Cr} \$ 22.500)$ ficou abaixo da média para o crédito no mesmo ano de 1979 (Cr\$ 25.852), deixando assim nenhuma sobra depois de cumprir os compromissos bancários. Uma explicação possível seria o caráter ainda fortemente de subsistência desta produção que permite a satisfação de muitas das necessidades da família através de produção própria. Neste caso, a alta porcentagem que enfatiza salários como o gasto maior em relação ao crédito seria um reflexo mais da persistência de um forte componente de subsistência, o que dificilmente pode ser reconciliado com a caracterização destes produtores como capitalistas, como faz a pesquisa.

Assim, embora os dados indiquem uma relação positiva entre o uso da mão de obra assalariada e o acesso ao crédito, a natureza desta mão de obra precisa de análise mais detalhada.

Em relação ao uso da mão de obra de fora, o questionário simplesmente pergunta se o trabalho temporário é utilizado a "cada ano" ou "de vez em quando", discriminando a situação antes e depois de utilizar crédito oficial e assistência técnica. Em primeiro lugar, não fica claro qual é a distinção exata entre estas duas categorias; um produtor que contrata mão de obra por uns dias a cada ano, um ano para colheita, outro para o plantio, e outro para consertar a cerca deveria responder "de vez em quando", mas no contexto das opções oferecidas pelo questionário será considerado como contratado "cada ano" e, portanto, "regularmente".

O crucial, porém, é que o nível de detalhe fica completamente insuficiente para especificar a posição deste trabalho dentro do processo produtivo. Quantos dias foram trabalhados? Em quais períodos do ciclo agrícola? Quantos trabalhadores foram contratados? Nenhum destes detalhes está disponível. Se a cada ano um trabalhador é contratado para ajudar na safra, isto transforma a produção familiar em empresa capitalista?
Como argumentamos nos Capítulos anteriores, o uso da mão de obra de fora é tradicional na produção familiar. ${ }^{54}$ Sem refletir sobre seu significado, a pesquisa nota o declínio de formas tradicionais de troca de serviços:

Formas espontâneas de cooperação mútua entre pequenos produtoras, sobretudo "mutirão" e "ajutório", estão diminuindo com a introdução de crédito rural (Op. cit., p. 66).

A monetarização da mão de obra, como argumentamos no Capítulo 3 , estabeleceu uma desigualdade de acesso a esta mercadoria ameaçando a viabilidade daqueles produtores incapazes de pagar a contratação. Mas isso não implica que o ato de contratar constitui por si só uma mudança para a agricultura capitalista. ${ }^{55}$

Neste contexto, é o declínio do trabalho fora da roça por parte do produtor que representa de longe o impacto mais significativo do uso de crédito. As cifras neste sentido são bastante reveladoras. Dos 144 (88\%) produtores que trabalhavam também como assalariados antes de receber o crédito do POLONORDESTE, apenas $41(24 \%)$ continuaram a se assalariar, depois de se beneficiarem destas facilidades.

Isto sugere, portanto, que a mudança decisiva produzida pelo crédito foi de transformar os beneficiários em produtores de tempo integral. Como resultado disso, podemos entender o aumento na área cultivada (de até $70 \%$ ) e também o aumento na demanda para mão de obra. ${ }^{56}$ Nesta interpretação, contudo, a contratação resulta da intensificação do trabalho do produtor direto, uma conclusão pouco compatível com a definição deste último como capitalista.

Os dados da pesquisa podem indicar apenas o uso de um montante indeterminado de mão de obra em algum momento durante o ciclo agrícola de cada ano. Mas não podem especificar o contexto de seu uso. O trabalho assalariado substitui a mão de obra familiar? É um mecanismo que permite o uso ótimo de trabalho familiar por todo o ciclo? Ou é uma consequência

\footnotetext{
${ }_{55}^{54}$ Veja Capítulo 2 e 3, passim.

55 Nosso trabalho de campo que será discutido no próximo Capítulo foi elaborado especificamente para esclarecer estas questões.

${ }^{56}$ Este aumento, porém, se refere ao total da área cultivada e não indica a porcentagem dos produtores que aumentaram suas áreas.
} 
da intensificação do trabalho familiar, sobretudo do chefe, que agora trabalha em tempo integral ? $^{57}$

Notamos antes aumento importante na área total cultivada pelos beneficiários do crédito, contra um declínio absoluto, no caso do público assistido mas sem usar crédito. ${ }^{58}$ Em relação a novas práticas adotadas como resultado de assistência técnica e crédito, as conclusões da pesquisa enfatizam a adoção preferencial daquelas práticas que não implicam custos monetários, como no caso de espaçamento que $77 \%$ dos entrevistados adotaram. Mas isto é verdade apenas até certo ponto, porque a adoção de práticas aparentemente caras pode reduzir a necessidade para a contratação de mão de obra cujo custo é ainda maior.

O que a pesquisa não analisa, contudo, é que todas estas práticas (com exceção da aração, que comentamos abaixo) tendem a aumentar a intensidade de trabalho por unidade cultivada como consequência da reorganização dos elementos tradicionais do processo de trabalho. A seleção das sementes, e o plantio, agora exigem trabalho mais especializado, que junto aos tratos culturais aumentam a demanda de trabalho para cada fase. Neste sentido o controle do processo produtivo, imposto pela integração na estrutura do capital financeiro, aponta inicialmente ${ }^{59}$ para um aumento na produtividade por área cultivada, através de um aumento absoluto no trabalho gasto para cada operação.

Este processo evoca a subordinação formal do trabalho na etapa manufatureira de industrialização, uma vez que reconhecemos que a produtividade deste trabalho deve ser vista em função da quantidade do produto final e não o montante de trabalho usado por área cultivada.

\footnotetext{
${ }^{57}$ Veja nossa discussão de Chayanov, no Capítulo 2.

${ }^{58}$ Um declínio geral de 8,88\%, p. 48, Op. cit.

${ }^{59}$ A existência de uma primeira fase como tal não é planejada, mas é produto de fatores limitantes tanto pelo lado do capital (falta de sementes selecionadas, mecanismos de crédito que tomam difícil o acesso a maquinaria), quanto de pequenos produtores (a relutância em aumentar suas despesas financeiras no contexto de repetidas frustrações de safra etc.). De fato, como veremos, a tendência decorrente da utilização de assistência técnica e crédito volta-se para a substituição de meios de produção tradicionais por meio de produção capitalista - como no caso da adoção de aração a trator. Para uma consideração detalhada desta questão, veja o Capítulo. 6.
}

No entanto, do ponto de vista do produtor, este processo representa um aumento absoluto nas necessidades de trabalho e é neste contexto que a questão de mão de obra contratada deve ser analisada.

Sem dados para esclarecer estas questões, é impossível definir o status da mão de obra contratada, como também não pode ser estabelecida a sua própria dinâmica. Para a pesquisa da Unidade Técnica a mera existência de mão de obra contratada, sem levar em conta sua quantificação ou condição de utilização, é suficiente para definir a unidade produtora como capitalista.

Simplificações desta natureza, fazem com que questões importantes não sejam analisadas. Por que o nível de crédito de investimento é tão baixo entre os que utilizam crédito? Existe uma tendência para o uso de implementos e equipamentos poupadores de mão de obra, e qual a sua relação com a contratação da mão de obra?

Na parte da pesquisa sobre a adoção de técnicas promovidas pela extensão rural, notamos que 33\% adotaram técnicas poupadoras de mão de obra como aração - $23 \%$ a trator, $13 \%$ tração animal. Particularmente interessante é a maior porcentagem de aração com uso de trator, que sai até muito mais caro (15\% indicaram este item como o elemento mais caro nos gastos de crédito).

Poder-se-iam aventar correlações entre estes dados -, área cultivada e uso de mão de obra - se os produtores que respondem mais aos incentivos do crédito oficial, no que diz respeito a área cultivada, estivessem ou não se tecnificando de maneira a diminuir ou eliminar a dependência de contratação.

Uma consideração mais detalhada dos dados da Pesquisa, em vez de sugerir a transformação de produtores tradicionais em capitalistas, como a tendência principal, aponta, portanto, para resultados mais modestos. Embora se argumente que a área cultivada pelos beneficiários do crédito aumentou em 70\% entre os anos 1977-79, as áreas totais cultivadas são bastante reduzidas (a média mais alta é a sub-região de Itaberaba com 6,9 ha). Existe, também, uma divergência bastante acentuada entre estas sub- 
regiões, com Seabra cultivando uma média de 5,7 ha e a região mais populosa Feira de Santana, com apenas 3,7 ha. ${ }^{60}$

4.3. Uma comparação entre a pesquisa de campo e os dados da Unidade Técnica

Estes dados da pesquisa de campo são até bastante elevados quando comparados com os dados globais sobre crédito conseguidos pela Unidade Técnica das agências bancárias na região do Programa. ${ }^{61}$

Tabela 21 - Área média cultivada pelo público do POLONORDESTE segundo ano e

\begin{tabular}{c|c|c|c} 
& \multicolumn{3}{|c}{ sub-região } \\
Ano & Itaberada & Seabra & Feira de Santana \\
\hline 1978 & 3,8 & 4,4 & 3,6 \\
\hline 1979 & 4,1 & 5,4 & 3,0 \\
\hline $1980^{*}$ & 3,74 & 3,3 & 2,6
\end{tabular}

*Dados provisórios.

Fonte: Unidade Técnica, Documentos sobre Crédito Rural.

Mais ainda, o público beneficiado com crédito fica muito aquém da meta de 4.000 por ano, e existe mesmo uma tendência para um declínio absoluto deste público, como indicam os totais dos beneficiados nos anos 1978-80: 1.649, 2.624 e 2.549 respectivamente.

Tendo em vista as pequenas áreas cultivadas pode se pensar que o público do POLONORDESTE venha basicamente das menores propriedades. Mas, embora $60 \%$ das propriedades nas três microrregiões do Programa sejam de menos de 10 ha, apenas 37\% do público do POLONORDESTE foi escolhido nesta faixa nos anos 1978 e 1979 , contra $48 \%$ para a faixa de 1050 e $15 \%$ para as propriedades acima de 50 ha.

A pequena e declinante porcentagem dos beneficiários do POLONORDESTE que utilizam crédito, e que representam apenas $7 \%$ do

${ }^{60}$ Embora seja bastante confusa e sem base em dados, a exposição sugere que de fato a área média declinou na região de Feira de Santana, o que coincide com os dados globais apresentados na Tabela acima.

${ }^{61}$ Os cálculos da EMATERBA para o público que usa crédito são muito mais altos e internamente contraditórios. Além das contradições internas, os dados da EMATERBA se baseiam nos planos de crédito contratados e não no crédito realmente liberado. Ainda assim, os dados da Ematerba são considerados irrealistamente altos pela Unidade Técnica do Projeto. público potencial, junto à inclusão preferencial das propriedades maiores, e ao fato de que os não-proprietários representam apenas $28 \%$ deste público, apontam para a existência de barreiras estruturais para a transformação do setor de pequena produção na bacia de Paraguaçu.

Tudo indica que a combinação de tamanho reduzido e baixa fertilidade faz com que o minifúndio típico da região seja inviável como unidade produtiva, e incapaz de gerar renda que permita a sua reprodução. Em três anos de utilização de crédito o público de Feira de Santana cultivou $29,3 \%, 31 \%$ e $22 \%$ da área total de suas propriedades apontando para uma porcentagem alta de terra infértil. ${ }^{62}$

Nesta região, a persistência maior de trabalho fora, mesmo depois da incorporação no sistema de crédito do POLONORDESTE, sugere um padrão de semiproletarização que permite a sobrevivência em unidades produtivas que de outra forma não seriam viáveis. ${ }^{63}$

Quebra nas safras e dificuldades com seguro de crédito podem ser citadas como fatores que inibem aumentos na produção e vontade para fazer benfeitorias. De 169 produtores, 73 (43\%) não puderam pagar seus empréstimos dentro do período estabelecido e apenas 31 destes conseguiram resolver o problema, através de seguro ou prorrogação das datas de pagamento. 36 produtores tinham que vender animais para pagar o empréstimo (21\% do total). ${ }^{64}$

Mas a alta proporção de produtores não atendidos pelo seguro de crédito (PROAGRO) é resultado do caráter subordinado da pequena produção na região. Em primeiro lugar, na região de Itaberaba, $45 \%$ dos nãoproprietários se constituem de arrendatários obrigados a plantar capim junto com a lavoura, prática que os exclui do sistema do PROAGRO por não atender as' precondições de utilização do crédito. ${ }^{65} \mathrm{Em}$ segundo lugar, os Relatórios da Extensão Rural falam insistentemente sobre a resistência dos bancos à incorporação dos pequenos produtores no esquema do PROAGRO. ${ }^{66}$ $\mathrm{E}$, por último, os médios e grandes proprietários não têm interesse em

\footnotetext{
${ }^{62}$ Pesquisa da Unidade Produtiva, p. 30.

${ }^{63}$ Idem, p. 63/4.

${ }^{64}$ Idem, p. 43.

${ }^{65}$ Idem, p. 26.

${ }^{66}$ Veja documento, Subprojeto de Assistência Técnica e Extensão Rural.
} 
defender o público do POLONORDESTE porque na sua grande maioria são pecuaristas ou cafeicultores.

Na região de Seabra, por exemplo, $60 \%$ dos créditos contratados para a safra de 1979/80 não foram liberados. ${ }^{67}$ O mesmo tipo de atraso na liberação de crédito de custeio na região de Irecê (veja Capítulo 6), em 1981, resultou numa campanha de pressão política que unificou pequenos, médios e grandes produtores (todos cultivando a mesma lavoura), que foi capaz de forçar a reabertura das linhas de crédito, feita pessoalmente pelo chefe da Carteira Agrícola do Banco do Brasil, enviado às pressas para esse fim. O grau menor de cooperação por parte da rede bancária em Paraguaçu resultou, portanto, na predominância de interesses ligados à pecuária e na pouca importância dada à lavoura de alimentos básicos. ${ }^{68}$

Todos estes fatores, portanto, baixa produtividade, alta porcentagem de não-proprietários, predominância de pecuária, menor grau de comprometimento por parte dos bancos, explica também, provavelmente, o pouco uso do crédito de investimento pelo público do POLONORDESTE.

A maior parte deste crédito se encontra na sub-região de Itaberaba e se destina quase que exclusivamente ao subprojeto para a promoção de pecuária em pequena e média escala ${ }^{69}$ Em 1978 , nas três subáreas, apenas 47 produtores eram beneficiários de crédito de investimento (34 na região de Itaberaba). Em 1979 este número aumentou para 131: 62 em Itaberaba, O em Feira de Santana e 69 em Seabra. Neste último caso, os itens financiados incluem animais de trabalho, implementos agrícolas, reformas de edifícios e cercas que beneficiariam mais a faixa de 0-50. De qualquer forma, os números absolutos são muito reduzidos.

Os dados para 1980 apenas discriminam por item de crédito segundo o tamanho da propriedade e não por número de beneficiários. No caso de Feira de Santana, 50\% dos investimentos foram liberados sob a rubrica

\footnotetext{
${ }^{67}$ Documento de Crédito Rural, 1980, Unidade Técnica.

${ }^{68}$ Documento de Crédito Rural, 1878-79. Resistência ao trabalho junto aos pequenos produtores ainda pode ser observada no caso de alguns gerentes do Banco do Brasil, e o tratamento deste público por parte de alguns dos funcionários do Banco se caracteriza por agressividade.

${ }^{69}$ O público para este subprojeto inclui produtores com até 200 ha, teto que os técnicos do programa acham deva ser reduzido para 100 ha.
}

"outros" que inclui elementos como animais de trabalho e implementos agrícolas, absorvidos pela faixa de 0-50.

Na região de Seabra, embora o item "outros" represente apenas $6 \%$ do valor total do crédito concedido, $88 \%$ do crédito de investimento foi tomado por propriedades na faixa de 0-50. Quase a metade deste crédito é destinado a cercas (uma tendência parecida pode ser notada no caso de Feira de Santana), o que representa, como veremos mais claramente nos Capítulos seguintes, o primeiro passo na consolidação e em melhoramentos da propriedade.

Embora a taxa de crescimento do crédito de investimentos entre o público do POLONORDESTE na bacia de Paraguaçu seja bastante limitada, os dados de 1980 mostram um desenvolvimento significativo. A este respeito o relatório EMATER-Ba sobre pequenos investimentos na região de Seabra é ilustrativo, conforme se vê na Tabela 22.

Tabela 22 - Sub-região de Seabra. Pequenos investimentos - 1980

\begin{tabular}{l|c|c}
\multicolumn{1}{c|}{ Itens } & Programados & Realizados \\
\hline Aração & 480 & 136 \\
\hline Gradeação & 480 & 10 \\
\hline Equipamento de plantio & 480 & 25 \\
\hline Cultivadores & 480 & 0 \\
\hline Reforma de edifícios & 480 & 339 \\
\hline Represas & 0 & 18 \\
Fonte: Relatório Sobre os & Resultados Alcançados pela EMATER-Ba (Unidade \\
Técnica.
\end{tabular}

Embora muito aquém das metas (e por essa razão são provavelmente confiáveis), estes dados, junto com os dados das fontes bancárias, apontam para o começo de um processo de tecnificação viabilizada pelo crédito oficial.

\section{Conclusão}

Nesta revisão crítica dos dados secundários e da pesquisa de campo feita na área do programa do POLONORDESTE para a bacia de Paraguaçu, podemos concluir que o envolvimento do setor da pequena produção nas estruturas de crédito oficial produz uma dinâmica que tem as seguintes características: uma ruptura parcial para com a sua subordinação tradicional ao capital mercantil, reduzindo a sua influência estritamente à esfera de 
comercialização (onde paradoxalmente sua influência é refortalecida); a eliminação da dependência de renda de fora da propriedade permitindo a criação de um produtor de tempo integral; um aumento na área cultivada acompanhado de uma intensificação do trabalho exigido para cada operação agrícola como consequência da influência de assistência técnica; um aumento no uso do trabalho assalariado; e finalmente uma tendência inicial para a tecnificação da produção (tração de animal e trator) e para melhorias na unidade produtiva (cercas, compra de animais, reforma de edifícios e armazenagem).

No entanto, as características históricas desta pequena produção na bacia de Paraguaçu (marginalização, semiproletarização no contexto da predominância de pecuária) têm estabelecido limites estruturais bastante fortes a estas transformações, impossibilitando conclusões concretas sobre a sua dinâmica.

No próximo Capítulo apresentaremos os resultados de nossa pesquisa sobre este tema, feita no contexto de um programa de colonização para pequenos produtores, onde os fatores limitantes de uma estrutura agrária dominada pelo latifúndio não estão presentes.

Como resultado, esperamos que a dinâmica das tendências analisadas neste Capítulo possam ser melhor captadas.

\section{Capítulo Cinco - Serra do Ramalho. Modernização e colonização} por pequenos produtores

\section{Introdução ${ }^{1}$}

O Projeto Especial de Colonização de Serra do Ramalho, localizado na margem oeste do rio São Francisco, do outro lado da cidade-santuário de Bom Jesus da Lapa, fornece em certos aspectos um caso puro de laboratório para se examinar a evolução da exploração agrícola familiar tradicional sob o impacto de uma estratégia modernizadora. O Projeto compreende cerca de 257.000 hectares, desapropriados em 1975 para receber um total projetado de 4.000 famílias. Esta população fora erradicada pela inundação provocada pela barragem de Sobradinho, construída mais acima do São Francisco, próxima à cidade de Juazeiro.

No entanto, a preferência dos colonos potenciais por outras alternativas, somada a uma alta taxa de desistência (mais de 20\%), levaram a que o Projeto fosse aberto primeiro a famílias das vizinhanças da área desapropriada, e depois a um público mais amplo, de modo que, na época de nossa pesquisa (junho de 1981), das pouco mais de 3.000 famílias já assentadas, apenas $30 \%$ eram da região de Sobradinho, com $50 \%$ de municípios vizinhos à área desapropriada, e $15 \%$ de outras regiões, principalmente Mato Grosso do Sul (mais de 200 famílias).

Assim o projeto, embora elaborado como um mecanismo específico para atenuar as consequências sociais de uma apropriação capitalista exógena da área rural destinada à barragem, foi redefinido de modo a

\footnotetext{
${ }^{1}$ Para um relato das tradições de produção destas pessoas antes de sua retirada do local, cf. Questão agrária e campesinato, Ed. Polis, 1980, Paulo Sandroni. O estudo de Ghislaine Duque, Estratégia camponesa: ação de classe disfarçada (Encontro Realidade Nordestina, Campina Grande, 1980), uma recapitulação dos temas de sua tese de doutoramento Casa Nova: Intervention du pouvoir et stratégie paysanne. Un municipe du Sertão baiano à l'heure de modernisation, Ecole des Hautes Etudes en Sciences Sociales, 1980, fornece um interessante relato das formas de resposta coletiva às opções apresentadas pelos órgãos estatais (inclusive a do Projeto de Colonização). Para uma descrição geral do impacto regional da barragem de Sobradinho, cf. Kathrein Tallworth, Der Staudam von Sobradinho: Infrastrukturelle Erschliessing einer Region und Verelendung und Proletarisierung von Subsistenzbauern, 1979, tese de mestrado, Universidade Bielefeld.
} 
integrar-se à política estatal mais ampla de solucionar a questão agrária através de projetos de colonização e fornecimento de títulos de propriedade.

Deste modo, o projeto veio a tornar-se um importante elemento na estratégia em escala nacional do INCRA para esvaziar bolsões de tensão social pela oferta de glebas legalizadas com infraestrutura básica; presentemente, o PEC/SR está sendo usado para esvaziar a luta dos lavradores sem-terra no Estado do Rio Grande do Sul. ${ }^{2}$ Do ponto de vista do INCRA, portanto, o projeto é acima de tudo um mecanismo social. ${ }^{3}$

Nisto, ele difere dos esquemas de colonização com base em irrigação, particularmente os da CODEVASF, ${ }^{4}$ também na região do São Francisco, e são antes de tudo projetos econômicos, cujos resultados são definidos em termos de produtividade, e não de títulos de propriedade de terra.

Todavia, os recursos do projeto vêm dos fundos do POLONORDESTE, e a estratégia de intervenção ao nível da produção é deixada essencialmente nas mãos da EMATER-Ba. Este órgão opera exatamente como no caso dos outros programas de desenvolvimento rural integrado, promovendo uma estratégia de modernização baseada, simultaneamente, na consolidação da pequena produção mercantil de unidades agrícolas de subsistência, e na subordinação de tal produção aos capitais industrial e financeiro através dos mecanismos do crédito orientado, assistência técnica, preços mínimos, seguro de crédito e cooperativismo.

\footnotetext{
${ }^{2}$ Centenas de famílias de lavradores sem-terra acamparam durante meses, em 1981, às margens da auto-estrada federal no Rio Grande do Sul, reivindicando acesso a terra no próprio estado. O INCRA. representando o governo federal, promoveu com certo sucesso a emigração para vários projetos de colonização, entre eles o de Serra do Ramalho, tendo as primeiras famílias chegado lá para inspeção em dezembro de 1981.

${ }^{3}$ Se podemos falar de uma estratégia econômica do INCRA para as áreas já ocupadas, ela é de eliminar o minifúndio e criar uma classe média rural. Cf. o Capítulo Um acima, que se refere especificamente ao Rio Grande do Sul.

${ }^{4}$ Companhia para o Desenvolvimento do Vale do São Francisco, cuja política corrente é de irrigação baseada em médias e grandes empresas.

5 Como consequência do grau em que a estratégia de intervenção reproduz o modelo de desenvolvimento rural integrado, estão-se preparando mudanças para a integração formal do projeto ao PDRI São Francisco, que opera com impacto mínimo em municípios vizinhos.
}

\section{Características específicas do projeto}

Comparado com a região de Paraguaçu, este projeto oferece um certo número de vantagens importantes. Todos os colonos são público potencial para o crédito orientado e a assistência técnica, tendo direitos iguais em relação a suas glebas, ${ }^{6}$ e, o que a nosso ver tem igual importância, cada família tem acesso igual à terra, compondo-se de 20 ha o lote básico. ${ }^{7}$ Além disso, a agência bancária local (o Banco do Brasil é o único a servir o projeto, até agora) não coloca nenhuma restrição ao acesso a crédito para investimento, embora este último sofra da limitação de quotas imposta à própria agência.

As casas dos colonos são agrupadas fora das glebas, em pequenas comunidades conhecidas como "agrovilas", compreendendo de 200 a 300 famílias. Estas concentrações permitem um acesso mais fácil e barateiam os serviços gerais tais como energia, água, saúde e comércio. Os serviços de extensão são distribuídos por todas as agrovilas, como o são, em grau muito menor, a infraestrutura de armazenagem e os serviços das Cooperativas.

Embora existam importantes desproporções no Projeto concentração dos escritórios centrais do INCRA, da Cooperativa, da Extensão Rural, Saúde e Educação em uma agrovila - elas são mínimas, se comparadas com as desigualdades estruturais que afetam programas de modernização como o de Paraguaçu, discutido acima.

Esta igualdade formal em relação aos serviços de modernização, no entanto, oculta severas diferenças culturais entre os diferentes grupos de colonos. O colono de Sobradinho, antes de sua incorporação forçada ao projeto, estava tradicionalmente mais acostumado a pesca com pequenas criações, que a trabalhar como lavrador. Os que vieram das áreas circunvizinhas ao projeto tinham fortes tradições agrícolas, particularmente em plantio de arroz, mas eram basicamente produtores de subsistência, e como posseiros e parceiros, tinham pouco ou nenhum contato com serviços

\footnotetext{
${ }^{6} \mathrm{Na}$ época da pesquisa, nenhum título de propriedade havia sido cedido, e o INCRA era o proprietário legal, concedendo direitos de uso aos colonos mas exercendo controle sobre tal uso (por exemplo, excluindo a exploração pecuária, reservada para a fazenda de criação de gado do Projeto).

${ }^{7}$ As poucas exceções foram devidas a condições de baixa fertilidade ou às miniglebas para pessoas aposentadas, no caso das que vieram de Sobradinho.
} 
de extensão rural ou crédito. Em contraste, os de Mato Grosso do Sul já haviam trabalhado com crédito bancário, extensão rural, insumos modernos e mecanização.

Contudo, embora estas diferenças fossem cruciais para se analisarem as diferenças de respostas à estratégia de modernização, o objeto de nosso estudo é o impacto do crédito e da extensão rural, uma vez adotados. Neste caso, diríamos que o crédito orientado incorpora mecanismos disciplinadores que tendem a homogeneizar as práticas agrícolas. Tais mecanismos vão desde a elaboração de planos de produção específicos, como precondição para o crédito, até o controle da liberação dos recursos, os critérios para a obtenção de seguros de créditos e as condições de pagamento.

Porém, um elemento que tem de ser levado em conta é o grau de tecnificação atingindo antes da incorporação ao projeto, e, como veremos, cuidados foram tomados durante a pesquisa para se discriminar a origem dos recursos para aquisição dos equipamentos agrícolas e outros implementos.

Assim, este projeto oferece formalmente a vantagem de colocar o pequeno produtor numa relação direta com as instituições de modernização, livrando-o das distorções impostas pela inserção na estrutura latifundiária (inserção que existia no caso de Paraguaçu, como vimos, e que é o caso típico do Nordeste como um todo). Além disso, o colono está, por definição, comprometido a assegurar sua manutenção com base na produção agrícola de sua gleba (isto vale mesmo para o caso de Sobradinho, onde existiam outras opções, por exemplo, emigração para as cidades), na medida em que a região circundante está ocupada por uma atividade pecuária em rápida expansão, absorvendo pouca mão de obra e expulsando a maioria da que estava tradicionalmente ali fixada. Desse modo, o colono, ao vir para o projeto, identifica-se antes de tudo como um agricultor.

\section{Análise dos dados globais}

Uma vantagem adicional de estudar-se este projeto é que os dados disponíveis dos vários órgãos executivos estão relativamente completos. Vamos examinar parte deste material antes de considerar a informação obtida diretamente pela pesquisa de campo.

\subsection{Crédito/área cultivada/mão de obra familiar disponível}

Se compararmos as áreas cultivadas por agrovila com a mão de obra familiar disponível, computadas todas as pessoas acima de quinze anos, vemos que, à exceção da agrovila 9, há uma relativa homogeneidade tanto na quantidade de mão de obra familiar disponível quanto na área cultivada. ${ }^{8}$ (Ver a Tabela 23.)

Tabela 23 - Área média cultivada e mão de obra familiar disponível por agrovila Safra de 1980/81

\begin{tabular}{c|c|c}
\multirow{2}{*}{ Agrovila } & $\begin{array}{c}\text { Área média cultivada (em } \\
\text { ha) com e sem crédito }\end{array}$ & $\begin{array}{c}\text { Mão-de-obra familiar } \\
\text { disponível }\end{array}$ \\
\hline 1 & 3,9 & 2,7 \\
\hline 2 & 4,8 & 2,6 \\
\hline 3 & 4,0 & 2,3 \\
\hline 4 & 5,9 & 2,5 \\
\hline 5 & 4,7 & 2,9 \\
\hline 6 & 4,6 & 3,1 \\
\hline 7 & 5,0 & 2,6 \\
\hline 8 & 5,9 & 2,8 \\
\hline 9 & 9,3 & 2,9 \\
\hline 10 & 4,6 & 2,4 \\
\hline 11 & 5,0 & 2,6 \\
\hline 12 & 4,9 & 2,6
\end{tabular}

Fonte: EMATER-Ba e FSESP. Cálculos do autor.

Neste sentido a agrovila 9, com uma alta média de 9,3 ha cultivados, pode ser vista como uma exceção. Ela é única com uma composição majoritária (e quase exclusiva) de agricultores provenientes de Mato Grosso do Sul, já experientes em métodos agrícolas modernos.

No entanto, se compararmos esta mesma mão de obra familiar disponível com a área médica cultivada por agrovila, mas agora discriminando esta área de cultivo segundo o emprego de crédito deparamonos com um quadro bastante diferentes (Tabela 24).

\footnotetext{
${ }^{8}$ Dados sobre a produção da EMATER-Ba, e sobre a composição familiar, da FSESP (Fundação Serviço Estadual de Saúde Pública). Infelizmente, os dados da FSESP não fornecem uma discriminação para crianças acima de dez anos, cuja inclusão provavelmente teria dado uma imagem mais exata da mão de obra familiar disponível. Não obstante, nossa discussão aqui é comparativa, pelo que os dados são perfeitamente adequados.
} 
Tabela 24 - Mão de obra familiar disponível e área cultivada por agrovila, com e sem emprego de crédito

\begin{tabular}{|c|c|c|c|c|c|}
\hline Agrovilas & $\begin{array}{c}\text { Área média } \\
\text { por unidade } \\
\text { com crédito } \\
\text { em ha }\end{array}$ & $\begin{array}{c}\text { Porcentagem } \\
\text { de usuários } \\
\text { de crédito } \\
(\%)\end{array}$ & $\begin{array}{l}\text { Área média } \\
\text { por unidade } \\
\text { em crédito }\end{array}$ & $\begin{array}{l}\text { Porcentagem } \\
\text { média por } \\
\text { unidade sem } \\
\text { crédito }(\%)\end{array}$ & $\begin{array}{l}\text { Mão-de-obra } \\
\text { familiar } \\
\text { disponível } \\
\text { (média) }\end{array}$ \\
\hline 1 & 5,5 & 53 & 2,2 & 47 & 2,7 \\
\hline 2 & 6,2 & 39 & 3,8 & 61 & 2,6 \\
\hline 3 & 4,4 & 88 & 2,3 & 12 & 2,3 \\
\hline 4 & 6,4 & 85 & 3,0 & 15 & 2,5 \\
\hline 5 & 5,6 & 66 & 3,0 & 34 & 2,9 \\
\hline 6 & 4,8 & 87 & 3,7 & 13 & 3,1 \\
\hline 7 & 6,1 & 54 & 3,8 & 46 & 2,6 \\
\hline 8 & 6,6 & 71 & 4,0 & 29 & 2,8 \\
\hline 9 & 9,4 & 98 & 3,8 & 02 & 2,9 \\
\hline 10 & 5,6 & 45 & 3,1 & 55 & 2,6 \\
\hline 11 & 5,8 & 70 & 3,5 & 30 & 2,4 \\
\hline 12 & 5,4 & 82 & 2,5 & 18 & 2,6 \\
\hline
\end{tabular}

O contraste fica ainda mais significativo quando se leva em conta que cada agrovila é relativamente homogênea, tendo-se feito a distribuição dos colonos provenientes de Sobradinho, das circunvizinhanças do projeto e de Mato Grosso do Sul mais entre agrovilas diferentes que dentro de cada uma delas. Em média, os que usam o crédito cultivam o dobro da área.

Várias hipóteses poderiam ser sugeridas para explicar estes fenômenos. Poder-se-ia pensar que as famílias que usam crédito têm mais mão de obra disponível que a média. No entanto, tal hipótese fica excluída quando se atenta para o caráter variável e majoritário dos que usam crédito (cf. Tabela 24, acima). Da mesma forma, a relativa homogeneidade de cada agrovila em termos da origem dos colonos eliminaria explicações baseadas em tradições agrícolas anteriores (embora estas tenham um importante papel, como o desempenho da agrovila 9 indica).

Assim, impõe-se a conclusão de que é o próprio crédito oficial que cria as condições para este aumento na área cultivada. Várias possibilidades, em combinação ou isoladamente, terão de ser examinadas durante nossa interpretação dos dados da pesquisa.

Com base na experiência de Paraguaçu, diríamos que o crédito reduz a necessidade de renda obtida fora da exploração agrícola, e permite uma dedicação integral à produção. Contudo, a força de um tal argumento é limitada pela falta de um mercado de trabalho desenvolvido (urbano ou rural) nas vizinhanças do projeto.

Uma possibilidade adicional a ser explorada, ainda com base nos resultados de Paraguaçu, é uma intensificação do trabalho como um efeito do crédito orientado, embora isso tenha estado mais relacionado a um aumento no trabalho despendido por unidade cultivada.

Se examinarmos os dados elaborados pela EMATER-Ba, sobre a área cultivada com e sem crédito, observamos que a discriminação segundo os produtos é idêntica. Uma possibilidade que examinaremos em relação aos dados da pesquisa é que os cálculos da EMATER-Ba não incluam os produtos típicos de subsistência e suas combinações que estão excluídos da lista dos produtos financiados pelo crédito oficial. Neste caso, a área cultivada pelos que não usam o crédito seria na realidade um tanto maior, diminuindo assim a diferença que favorece os usuários do crédito. Mesmo assim, é improvável que isto explique toda essa diferença.

Pode ser também que os usuários do crédito oficial adotem métodos de mecanização (neste caso, tração animal), facilitados pelo crédito de investimentos, que permitam um substancial aumento na área cultivada com o mesmo dispêndio de trabalho.

E, por fim, como no caso de Paraguaçu, é possível que o crédito seja o fator decisivo, permitindo a contratação de trabalhadores e a superação dos limites do trabalho familiar.

\subsection{Demanda de mão de obra e mão de obra familiar disponível}

Antes de examinar os resultados da pesquisa, podemos fazer uma ideia das dimensões da demanda de trabalho por unidade de área cultivada por meio de uma análise dos planos de crédito, que discriminam a mão de obra necessária segundo o sistema de produção, e para cada operação do ciclo agrícola.

Empregando os cálculos da EMATER-Ba, segundo os quais são necessários em média 30 homens/dia por hectare para limpeza do terreno, 13 para o preparo do solo e plantio, e um número semelhante para a colheita (estas são as médias para os diferentes produtos e combinações de produtos, 
cujas variações são pequenas), ${ }^{9}$ calculamos o tempo necessário empregando-se apenas o trabalho familiar, baseando-nos nas médias por agrovila de área roçada e plantada com uso do crédito, e nas médias de tamanho familiar.

Supondo-se 24 dias de trabalho por mês, com trabalho exclusivamente familiar seriam necessários de 2 a 3,5 meses para a limpeza do terreno, e de 1 a 2 meses para o plantio e a colheita, com uma média de 5 semanas para cada uma dessas duas operações.

Uma vez que se reconheça deverem ser todas estas operações concluídas o mais rapidamente possível, para as ervas daninhas não tomarem a crescer antes do novo plantio, para as sementes poderem beneficiar-se da efêmera umidade das chuvas, e para a colheita não ser ameaçada por estas mesmas chuvas, fica claro que o trabalho unicamente familiar estará, no melhor dos casos, extremamente sobrecarregado, e será em geral absolutamente insuficiente. A proporção e distribuição precisas do trabalho assalariado e sua relação com o trabalho familiar serão examinadas na seção dedicada aos dados da nossa pesquisa. ${ }^{10}$

\subsection{Crédito e tecnificação}

Entre as safras de 1979/80 e 80/81, o número dos que recorreram ao crédito aumentou em cerca de $300 \%$, subindo de 499 para $1.530 ;{ }^{11}$ mas, mesmo com este enorme aumento no número de usuários do crédito, a área média cultivada teve um aumento fracionário, de 5,6 para 5,7 ha.

${ }^{9}$ Os cálculos da EMATER-Ba, para o preparo do solo, plantio e colheita são os seguintes, para os principais produtos e combinações de produtos cultivados no Projeto:

\begin{tabular}{l|c|c} 
Produtos & Preparo de solo/plantio & Colheita \\
\hline Algodão & 12 & 10 \\
\hline Arroz & 14 & 8 \\
\hline Amendoim & 12 & 7 \\
\hline Mamona/Milho & 13 & 8 \\
\hline Mandioca/Milho & 16 & 7
\end{tabular}

${ }^{10}$ É interessante assinalar que os dados empregados aqui para a área realmente cultivada são inferiores às médias contidas nos planos de crédito para a mesma safra: Agr. 1-6,1; Agr. 28,8; Agr. 3-4,9; Agr. 4-7,0; Agr. 5-5,9; Agr. 6-6,1; Agr. 7-6,6; Agr. 8-7,0; Agr. 9-9,2; Agr. 10-6,7; Agr. 11-6,3; Agr. 12-5,7. Isto pode ser uma indicação adicional da limitação do trabalho familiar associada a dificuldades para a obtenção de mão de obra extrafamiliar.

${ }^{11}$ Nos planos para o crédito, este número era ainda mais alto: 1.802 .
O mais significativo, porém, foi o forte aumento na importância do crédito de investimento nas três últimas safras, subindo de $32 \%$ para $43 \%$ e $63 \%$ do total do crédito liberado, o que contrasta visivelmente com o caso de Paraguaçu. ${ }^{12}$

Só existem dados disponíveis sobre a natureza destes investimentos para 1980/81 (Ver Tabela 25). A predominância de "limpeza do terreno" é acentuada no caso deste Projeto, pois apenas 2 ha em cada lote foram desbravados pelo INCRA. Assim, qualquer avanço da área cultivada exige limpeza de terreno, a qual, como vimos, é extremamente trabalho-intensivo, além de depender exclusivamente de trabalho masculino. Deste modo, pode-se admitir que um importante motivo para se recorrer a crédito de investimento para limpeza de terrenos é, além da manutenção do trabalhador familiar, a necessidade de contratar mão de obra.

Embora este problema seja acentuado no caso do PEC/SR, é importante reconhecer que a transformação da produção de subsistência tradicional em unidades agrícolas comerciais, em razão da pequena área tradicionalmente cultivada, envolverá a necessidade de limpeza de novos terrenos e, com isso, a necessidade de crédito de investimento.
${ }^{12}$ Compreendendo um limite de Cr\$ 100 milhões para limpeza de terrenos e Cr\$300 milhões destinados a benfeitorias e equipamentos agrícolas. 
Tabela 25 - Discriminação do crédito de investimento segundo agrovila (safra

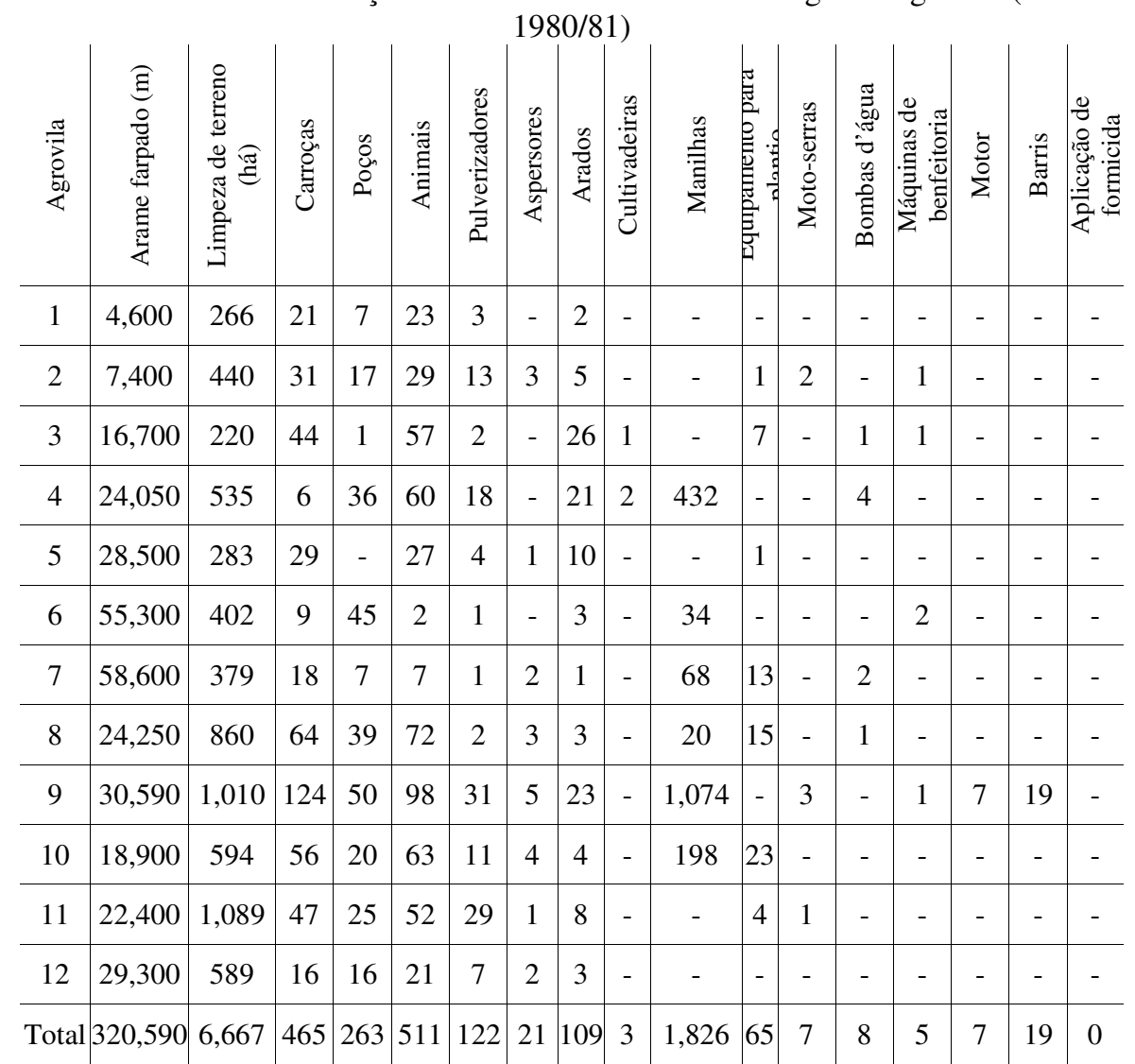

Fonte: EMATER-Ba, 1980/81, PEC/SR.

O segundo item a sobressair-se na tabela é relativo à construção de cercas. Uma das consequências da incorporação ao crédito orientado, no caso dos programas de modernização de pequenos produtores, é a valorização das lavouras, quando um ou dois produtos tradicionais são escolhidos para a produção comercial. As cercas são cruciais para isolar a lavoura dos pequenos animais domésticos que formam uma parte integrante da produção tradicional de subsistência. Assim, o cercamento da terra é uma consequência imediata da nova importância comercial conferida à produção.
Podemos dizer, portanto, que a incorporação ao crédito de custeio a curto termo leva a um envolvimento simultâneo com o crédito de investimento.

Assim, isto não representa um estágio avançado, consequente à consolidação da produção comercial, mas é a precondição para esta consolidação. Deste modo, o pequeno produtor fica rapidamente sobrecarregado com a necessidade de produzir o suficiente para quitar não só o crédito de custeio de curto termo, mas também as prestações dos empréstimos para investimentos. Os três itens que se seguem na Tabela podem também ser encarados como correspondentes a precondições para se transformar o estabelecimento agrícola numa unidade comercial. Cavalos e carroças são usados para transportar trabalhadores agrícolas, intensificando assim o tempo de produção no estabelecimento, e também para transportar equipamentos, sementes e produtos da safra, provendo assim também um meio de transporte interno para a unidade agrícola. A necessidade de suprimentos de água dentro dos lotes também é uma consequência deste maior investimento de recursos humanos e animais no próprio empreendimento agrícola. ${ }^{13}$

Contudo, embora estes itens sejam os mais onerosos em termos do crédito de investimento, eles se colocam sobretudo como precondições no contexto do projeto, onde os colonos moram afastados da unidade produtiva. $^{14}$

O número de arados incluídos nos empréstimos para investimento representa um avanço significativo na transformação das condições do processo de trabalho, reduzindo o trabalho necessário para o preparo do solo, que, como vimos acima, demanda excessivos homens/hora em termos de trabalho familiar.

$\mathrm{E}$, finalmente, o número de pulverizadores incluídos reflete um emprego crescente dos insumos modernos promovidos pelo "pacote tecnológico" da extensão rural.

\footnotetext{
${ }^{13}$ Além disso, estes poços, embora não sirvam para irrigação, permitem a manutenção das pequenas criações domésticas, que, no caso do Projeto, não são financiadas pelo crédito oficial, mas formam parte da "economia clandestina" dos colonos.

${ }^{14}$ Seriam necessários 4 sacos de 60 quilos para o cultivo de 6 hectares, e as glebas ficam muitas vezes a até $4 \mathrm{~km}$ das agrovilas.
} 
É importante distinguir a questão do crédito de investimento da questão da "tecnificação". Como vimos, o principal componente do crédito de investimento não se refere diretamente a transformações do processo de trabalho, nem à absorção de insumos agroindustriais modernos. A transformação de produtores de subsistência em consumidores de arame farpado, cavalos e carroças, e material para construção de poços, só beneficia diretamente a interesses tradicionais do pequeno capital, e portanto não pode ser encarada como parte da estratégia da agroindústria. Mais que tudo, essa transformação é um efeito da integração à agricultura comercial pela absorção de insumos específicos - sementes selecionadas, fertilizantes, defensivos etc. e esta é a chave da estratégia de modernização.

Não obstante, esta necessidade de "capitalizar" é crucial no que tange a seu impacto sobre os pequenos produtores, na medida em que eles são imediatamente lançados a uma dependência do crédito de investimento e à sobrecarga extra de sua quitação. Assim, os pequenos agricultores são colocados numa posição de risco crescente face à eventualidade de uma má colheita.

Esta dependência aumentada em relação ao crédito deve portanto ser distingui da, em termos analíticos, de um processo de tecnificação, expresso pela incorporação de insumos agroindustriais modernos como precondição para a produção. Esta tecnificação manifesta-se de duas formas: primeiro, pela subordinação do processo de trabalho a meios de produção gerados em moldes capitalistas - inicialmente sementes selecionadas, adubos e defensivos, financiados pelo crédito de custeio - que, por sua vez, criam a necessidade de equipamentos agrícolas modernos (aqui, representados pelos pulverizadores), levando ao endividamento pelo uso do crédito de investimento. E, em segundo lugar, a mecanização buscada como alternativa face ao aumento da demanda de trabalho (no nosso caso, os arados representam este tipo de insumo economizador de mão de obra), mas também assim o pequeno produtor vê-se cada vez mais enredado em empréstimos para investimento. Em nossa análise dos dados da pesquisa, vamos considerar mais detalhadamente a relação precisa entre este processo de tecnificação e as estruturas do crédito de investimento oficial.

\subsection{Evolução do projeto nos anos iniciais}

Embora a expansão e aprofundamento contínuo do envolvimento com as estruturas oficiais do crédito e da assistência técnica tenha sido notável nas três últimas safras, foi o oposto o que ocorreu nos primeiros anos do projeto.

Como indicamos acima, na área desapropriada não existia uma tradição de cultivo comercial de alimentos que pudesse guiar os colonos. Estes eram, como já vimos, mais pescadores e criadores de gado que agricultores, e não tinham experiência com produção agrícola não-irrigada.

Em 1976/77, a EMATER-Ba elaborou planos detalhados de crédito para os 1.240 colonos provenientes de Sobradinho. Usando os dois hectares desbravados pelo INCRA como base, estabeleceu o objetivo de um hectare de milho consorciado com feijão, e outro de algodão. Mas, pelo relatório deste órgão no final do ano, fica claro que seus objetivos só tiveram um sucesso limitado, tendo sido substituídas as culturas programadas por uma variedade de outros produtos - arroz, mamona, mandioca, amendoim.

Reconhecendo a necessidade de se adotar uma flexibilidade maior ("A inserção numa economia de mercado deve ser conduzida sem que quebrem os valores e tradições anteriores" $"$ ), mas sem reconhecer a conexão entre uma economia de mercado e uma ruptura com os "valores e tradições anteriores", a EMATER-Ba manteve a prioridade de feijão e algodão para a safra seguinte, que foi um fracasso completo.

Como resultado, em 1978/79, apenas 10\% utilizaram-se do crédito oficial, e cerca de 300 famílias deixaram o projeto, tendo o resto recaído numa economia de subsistência. Isto levou a um marcado declínio na área total cultivada, e ao virtual abandono do algodão, que tinha sido imposto explicitamente para se garantir a comercialização, e com ela o pagamento dos empréstimos para investimentos. ${ }^{16}$

Aqui, uma série de aspectos merecem ser assinalados. A falta de tradição agrícola teve certamente um papel neste quadro, especialmente no que tange ao cultivo do algodão - lavoura que requer conhecimentos

\footnotetext{
${ }^{15}$ Relatório da agência da EMATER-Ba, encarregada do Projeto, 1978.

${ }^{16}$ A informação contida neste parágrafo e nos seguintes provém do relatório da EMATER-Ba mencionado acima
} 
especiais ${ }^{17}$ e um tratamento cuidadoso durante a fase de crescimento. Porém, os problemas-chave derivaram de deficiências internas aos próprios mecanismos modernizadores - do lado da produção, "sementes de baixa qualidade genética [feijão] e excessivos ataques de insetos [ao algodão]", ${ }^{18}$ e, no caso de crédito oficial, uma recusa em incluir os colonos no esquema de seguro de crédito (PROAGRO).

É interessante que cerca de $25 \%$ dos colonos tenham abandonado o Projeto, mesmo sendo um projeto onde não existam pressões para sair e onde o INCRA não impôs sanções aos que ficaram em débito com o Banco. Os colonos que ficaram só puderam inscrever-se para o crédito em safras futuras na base de uma renegociação de seu débito.

Contudo, pode-se constatar que esta reversão a uma economia de subsistência não devia ser encarada como uma fuga à subordinação ao capital financeiro, mas sim como uma reincidência na estagnação: o interesse pelo crédito oficial renovou-se, tão logo se viu o esquema de seguro operando na safra seguinte. Isto coincidiu com uma atitude mais positiva para com os pequenos produtores por parte da agência local, que, até a chegada dos colonos, lidava quase que exclusivamente com comerciantes. ${ }^{19}$ Com a proclamação de uma anistia para o pagamento dos créditos cedidos durante a safra de 1981, atingida pela seca - anistia esta que a agência bancária local estendeu a todos os débitos contraídos desde o começo do projeto - a demanda pelo crédito subiu a quase $100 \%$.

Esta experiência nos primeiros anos do projeto confirma mais uma vez numa forma negativa a relação entre aumentos na área cultivada e o uso do crédito, e aponta para as raízes conjunturais da volta à produção de subsistência (falta de seguro de crédito); que, por sua vez, não deve ser encarada como um avanço na direção da liberação do pequeno agricultor tradicional. Dada a elevada proporção dos que abandonaram o programa, sem que tivesse havido uma ameaça direta aos direitos sobre a terra,

\footnotetext{
${ }^{17}$ Embora a estratégia da assistência técnica seja a de substituir as práticas "rudimentares" do produtor direto pelo "conhecimento especializado", não se pode dizer que isto tenha sido aplicado nas condições de implantação do Projeto.

${ }_{18}$ Aqui, leia-se: falta de emprego efetivo de inseticidas.

${ }^{19}$ De acordo com o Diagnóstico da Região feito pela EMATER-Ba em 1976 os comerciantes foram responsáveis por $98 \%$ dos contratos, e por $83 \%$ do valor total do crédito oficial cedido.
}

podemos imaginar que o endividamento, associado a um provável retorno à dependência do capital mercantil tradicional, ${ }^{20}$ representariam a última resistência antes da emigração. Por outro lado, o espaço para o arbítrio na aplicação do esquema de seguro de crédito colocava o pequeno agricultor modernizado sob um alto risco, particularmente se considerarmos a hostilidade da agência bancária local à orientação do pequeno produtor.

\section{Interpretação dos dados recolhidos no estudo de campo}

A detalhada pesquisa que realizamos na área, em julho de 1981, permitiu um exame mais global dos efeitos da incorporação ao crédito oficial, particularmente no que tange a seu impacto sobre o processo de trabalho.

\subsection{Escolha da amostra}

Com base na variável-chave, "uso ou não" do crédito oficial, uma amostra aleatória, distribuída segundo a área cultivada e a agrovila, foi extraída do local dos colonos que usaram e não usaram o crédito, de acordo com os dados da EMATER-Ba, para pelo menos duas safras. O tamanho da amostra foi baseado numa margem de erro de 5 a $6 \%$, respectivamente, para usuários e não-usuários do crédito, resultando num total de 31 usuários e 46 não-usuários do crédito oficial.

Os dados da Tabela 26, que representam o universo do qual a amostra foi extraída, fornecem uma indicação dramática do impacto do crédito, pois exigiram a elaboração de dois grupos de distribuição com respeito à área cultivada, em vista das áreas reduzidas dos não-usuários do crédito.

Tabela 26 - Universo do qual foi extraída a amostra de pesquisa* a) Produtores que recorreram ao crédito por 2 anos

\begin{tabular}{c|c|c|c|c|c}
\hline Agrovilas & Subtotal & $0-5$ & $5-10$ & $10-15$ & $15-20$ \\
\hline 1 & 21 & 9 & 8 & 2 & 2 \\
\hline 2 & 6 & - & 4 & 1 & 1 \\
\hline 3 & 17 & 12 & 4 & 1 & - \\
\hline 4 & 28 & 5 & 16 & 7 & -
\end{tabular}

${ }^{20} \mathrm{O}$ medo que o pequeno produtor teria do endividamento é frequentemente aduzido como um fator de limitação em relação à modernização induzida pelo crédito oficial. Mas esta posição não leva em conta o endividamento crônico do pequeno produtor nas mãos do capital mercantil tradicional, a taxas de juros muito mais altas. 


\begin{tabular}{c|c|c|c|c|c}
5 & 2 & - & 2 & - & - \\
\hline 6 & 25 & 10 & 11 & 3 & 1 \\
\hline 7 & 13 & 4 & 7 & - & 2 \\
\hline 8 & 99 & 30 & 54 & 13 & 2 \\
\hline 9 & 86 & 7 & 47 & 24 & 8 \\
\hline 10 & 69 & 17 & 44 & 6 & 2 \\
\hline Total & 366 & 94 & 197 & 57 & 18 \\
\hline
\end{tabular}

b) Produtores que não recorreram ao crédito por 2 anos

\begin{tabular}{c|c|c|c|c|c}
\hline Agrovilas & Subtotal & $0-2,5$ & $2,5-5$ & $5-7,5$ & $7,5-7$ \\
\hline 1 & 43 & 36 & 6 & 1 & - \\
\hline 2 & 81 & 38 & 26 & 9 & 8 \\
\hline 3 & 32 & 19 & 12 & 1 & - \\
\hline 4 & 47 & 31 & 12 & 2 & 2 \\
\hline 5 & 64 & 38 & 20 & 5 & 1 \\
\hline 6 & 59 & 16 & 18 & 11 & 14 \\
\hline 7 & 32 & 6 & 22 & 4 & - \\
\hline 8 & 65 & 32 & 18 & 9 & 6 \\
\hline 9 & 11 & 6 & 3 & 1 & 1 \\
\hline 10 & 73 & 26 & 27 & 6 & 14 \\
\hline 11 & 22 & 10 & 12 & - & - \\
\hline 12 & 14 & 10 & 4 & - & - \\
\hline Total & 543 & 268 & 180 & 49 & 46
\end{tabular}

Fonte: EMATER-Ba e CEPA-Ba.

* Após examinar-se a distribuição da área exata cultivada por cada produtor foi elaborado um novo estrato de divisão. Os usuários de crédito foram divididos entre os cinco grupos a seguir: 0-3 ha; 3-6 ha; 6-10 ha; 10-15 ha e 15 ha ou mais. Os nãousuários foram divididos em grupos de $0-1 ; 1-3 ; 3-6 ; 6-10$ e 10-15 ha.

\subsection{Crédito oficial e capital mercantil}

Mais que no caso de Paraguaçu, aqui o crédito oficial tem uma predominância quase exclusiva e apenas um colono da amostra dos usuários do crédito oficial indicou uma fonte suplementar de empréstimos, sob a rubrica "parentes e amigos".

Pode-se pensar que esta ausência de capital proveniente dos fornecedores tradicionais de empréstimos fosse um produto específico do caráter do projeto, que é controlado pelo Estado. Até um certo ponto, esta explicação é válida; mas os dados referentes à comercialização mostram que o capital mercantil de modo algum foi excluído pela existência de uma
Cooperativa dentro do projeto. Na realidade, a figura do carreteiro na região foi fortalecida pela criação do projeto, e até predomina para os dois produtos mais cultivados: milho e algodão.

No decorrer de nossas investigações descobrimos duas outras fontes não-agrícolas de renda dos colonos. A primeira delas, produto do estado virgem em que se encontravam muitos dos lotes, foi a madeira, objeto de atividade intensa, embora localizada. Sua comercialização representou conjunturalmente, para vários agricultores, a principal fonte de renda, em vista dos repetidos fracassos de safras.

Um bem organizado sistema de carreteiros é o maior beneficiário deste comércio, apesar da intervenção paralela da Cooperativa, que também possui uma serraria dentro do projeto. Mas esta é uma rede de comércio especializada, que não forma parte do capital mercantil responsável pela comercialização dos gêneros alimentícios produzidos no projeto, e não há evidência de seu envolvimento enquanto fonte não-oficial de crédito.

A segunda fonte de renda não-agrícola dos colonos só foi detectada no decorrer de nossa investigação, e, embora não fosse passível de quantificação por meio das entrevistas formais, pareceu representar uma fonte possível de capital usuário mercantil disfarçado.

Observou-se que, especialmente nas agrovilas menos orientadas para o crédito oficial, vários colonos mantinham pequenos estoques de alimentos enlatados, e outros gêneros de diversos tipos, para venda. A hipótese de que isso refletisse um processo de "kulakização", envolvendo uma diversificação de interesses por parte dos agricultores mais bem-situados, teve de ser descartada, em vista da associação desta venda com a categoria mais pobre dos colonos.

$\mathrm{Na}$ realidade, estes gêneros são cedidos por comerciantes da cidadezinha próxima, a preços iguais ou superiores aos do varejo local, numa base renovável quinzenalmente, com taxas de juros incluídas. Para o colono, por sua vez, isto representa uma pequena fonte de renda monetária regular, e talvez também uma fonte complementar de consumo.

As condições de monopólio criadas pelo projeto de colonização permitem, portanto, uma fusão peculiar dos capitais mercantil e usuário tradicionais. Não obstante, embora possa representar um importante mercado para um ou dois comerciantes, este monopólio se restringe aos 
espaços deixados pelos armazéns oficiais da COBAL (Cia. Brasileira de Alimentos), localizados em cada agrovila.

Assim, podemos dizer que o projeto abriu uma certa área para o capital usuário, envolvendo uma fração não insignificante de colonos; mas estes, em geral, estão entre os (mais marginais) não-usuários do crédito oficial. Tal hipótese é confirmada pela amostra baseada em não-usuários do crédito oficial.

Infelizmente, esta amostra foi afetada pela inadequação dos dados da EMATER-Ba, no sentido em que $26 \%$ dos colonos incluídos entre os "nãousuários de crédito por dois anos" tinham recorrido a alguma forma de crédito oficial em um desses dois anos. Porém, dentre eles, quase a metade só havia recebido crédito de investimento para limpeza de terreno. Outros $11 \%$ do total, embora não tivessem usado o crédito nos anos em que os cálculos foram baseados, tinham recorrido a ele em anos anteriores.

Assim, podemos dizer que cerca de $25 \%$ dos não-usuários do crédito oficial na amostra tinham experiência com crédito para custeio, embora apenas dois deles estivessem usando tal crédito para o ano agrícola em que a pesquisa foi realizada. A maioria dos ex-usuários do crédito haviam-no empregado na safra desastrosa de 1977/78, e como resultado tinham desistido em anos subsequentes. Várias substituições foram feitas para se manter a pureza da amostra, mas nem sempre isto foi possível. Além disso, nove dos entrevistados não conseguiram completar o questionário adequadamente, reduzindo-se assim a amostra final de 46 para 37. Nossa análise deverá portanto levar em conta estes fatores limitativos, empregando a amostra dos não-usuários do crédito oficial mais para fins ilustrativos do que conclusivos.

O que podemos concluir das dificuldades envolvendo esta amostra é que, estando o crédito oficial geralmente disponível no projeto, isto tem suas repercussões mesmo para aqueles que não se beneficiam de tal crédito. Isto fica claro pelo fato de que nenhum dos incluídos na amostra dos nãousuários tenha declarado ser dependentes de outras fontes de crédito. Parece, então, que os colonos optam por esta forma de crédito, ou então preferem fiar-se em seus próprios recursos. A entrada do capital usuário tradicional não é proibida pelo INCRA, mas tem seu âmbito de ação quase eliminado pela opção do crédito oficial.

\subsection{Crédito e produtor de mercadorias em novo estilo}

Se o crédito oficial marginaliza o capital usuário tradicional para os colonos integrados aos empréstimos bancários, a produção agrícola passa a ser uma função quase exclusiva deste crédito, com a área plantada $(161,1$ ha) sendo virtualmente igual à área programada (162,8 00).

Isso significa que a safra toda é agora encarada sobretudo em termos comerciais, e só após os empréstimos terem sido pagos é que o agricultor pode optar pelo consumo doméstico de uma fração dos produtos de sua colheita. A proporção da safra não comprometida pelas condições do crédito irá diminuir ainda mais quando o agricultor começar a resgatar as parcelas do crédito de investimento, além do crédito de custeio. Por sua vez, esta pressão para o pagamento levará à escolha de produtos para plantio em função de preços mais elevados, embora o ritmo de tal tendência vá ser determinado pela extensão da experiência de cada agricultor, somada à estrutura de comercialização existente na área.

A subordinação da produção às determinações do crédito oficial acarreta, portanto, como consequência necessária, a eliminação da agricultura de subsistência; a produção e o consumo perdem sua relação direta, passando a ser mediados pelo mercado. Mas, ao mesmo tempo, as condições clássicas da produção simples de mercadorias, registradas na fórmula de Marx “ $M-D-M$ ”, também não ocorrem. $\mathrm{O}$ ciclo de produção do agricultor em processo de modernização deve agora ser definido como " $D$ $M^{1}-M^{2}-D^{2}$ ”, onde $D^{1}$ representa o crédito oficial, $M^{1}$ os insumos e mercadorias que possibilitam a produção (sementes selecionadas, trabalho assalariado, adubos, defensivos), $M^{2}$ os produtos colhidos, e $D^{2}$ o seu preço no mercado. Só na medida em que $D^{2}$ exceda $D^{1}$, existirá a possibilidade de $M^{3}$ (mercadorias para consumo familiar), e $D^{3}$ ( abrindo condições para a continuação autônoma do ciclo de produção, mesmo para a acumulação).

É claro, porém, que $D^{2}$ pode ser menor que $D^{1}$. Neste caso, o crédito oficial é capaz de impedir a reversão à produção de subsistência pela eliminação da diferença (no caso da aplicabilidade do seguro de crédito) ou pela sua absorção por meio de novos empréstimos, sem prejuízo a curto prazo para as perspectivas de produção, mas com a probabilidade de que futuros $M^{3}$, e mesmo $D^{3}$, vão ser severamente reduzidos. Exploraremos melhor este elemento mais adiante neste Capítulo, quando considerarmos a renda agrícola. 
4.4. Assistência técnica, especialização de produtos e transformação do processo de trabalho

Tendo estabelecido o grau em que os usuários do crédito oficial têm seus planos de produção totalmente determinados por ele, passemos agora a um exame dos efeitos deste crédito orientado e das transformações que ele provoca no processo de produção.

Como consequência, principalmente, de se ter caracterizado a produção do pequeno agricultor, nos debates sobre a agricultura brasileira, como a fonte dos alimentos básicos (feijão, arroz, farinha), um dos efeitos centrais do crédito tem passado repetidamente despercebido.

Dentro da problemática da modernização do pequeno produtor, esta questão assumiu a forma de uma discussão sobre dever-se ou não considerar o crédito como um mecanismo para consolidar esta produção de gêneros alimentícios, entendida como extensão orgânica da produção tradicional de subsistência, ou se as culturas tipicamente "comerciais" deviam também ser estimuladas. ${ }^{21}$

Esta polarização, contudo, obscurece a novidade crucial do crédito, que, independentemente da promoção de culturas alimentares típicas ou "comerciais", gera uma profunda ruptura com o padrão da agricultura familiar tradicional, pela imposição de uma produção especializada.

As linhas de crédito são liberadas para produtos específicos e combinações limitadas de culturas, enquanto a agricultura familiar tradicional mescla toda uma gama de lavouras dentro de uma mesma área cultivada. Ao tempo de nossa pesquisa, o contraste entre os padrões de produção dos usuários e não-usuários de crédito era tão grande que os códigos de produtos, elaborados com base nos padrões de produção promovidos pelo crédito, tiveram de ser grandemente ampliados, para incluir as mais variadas combinações de lavouras que os não-usuários de crédito adotavam.
Assim, o principal impacto qualitativo do recurso ao crédito é que a família, ao lançar mão dele, sofre um processo de especialização produtiva, qualquer que seja o produto promovido.

A mudança de cinco ou seis culturas alimentares para uma ou duas não é uma simples redução quantitativa, na medida em que destrói a base da produção familiar de subsistência e, com isso, transforma os produtos remanescentes em culturas comerciais, eliminando assim a distinção entre produção comercial e a de "culturas alimentares".

Esta transformação, por sua vez, desloca os padrões anteriores, impondo uma simultaneidade maior nos elementos do processo produtivo, $\mathrm{e}$ criando uma pressão pela extrapolação dos limites do trabalho familiar. Além dessa mudança qualitativa, percebe-se que a influência da assistência técnica impõe modificações na maneira de se conduzir o processo produtivo, em relação a estas culturas tradicionais (ver Tabela 27, adiante). $58 \%$ dos respondentes declararam que seus sistemas de produção tinham sido indicados pela Assistência Técnica, e outros 54\% afirmaram que esta última havia também influenciado suas técnicas produtivas. Indagados sobre o impacto da Assistência Técnica sobre o volume do trabalho agrícola, $73 \%$ dos produtores declararam que esta havia aumentado, enquanto que, em contraste, apenas $27 \%$ acusaram um aumento na produção.

\footnotetext{
${ }^{21}$ No contexto deste debate o Banco Mundial tem enfatizado a produção dos alimentos básicos tradicionais à pequena produção (vejam propostas do Banco em relação as PDRI Paraguaçu).
} 
Tabela $27 *$ - Influência da assistência técnica de acordo com o estrato e a agrovila (usuários de créditos)

\begin{tabular}{|c|c|c|c|c|c|c|}
\hline Estrato / Agrovila & $\begin{array}{l}\text { Escollha de Lavou- } \\
\text { ras sugeridas pela } \\
\text { ass. tecrica }\end{array}$ & $\begin{array}{l}\text { scolha de lavou- } \\
\text { ras feitas pelo } \\
\text { produto }\end{array}$ & $\begin{array}{l}\text { Téc. prod. influen- } \\
\text { ciadas pela ass. } \\
\text { técnica }\end{array}$ & $\begin{array}{l}\text { Téc. prod. nâ } \\
\text { influenciadas pe } \\
\text { ass. técnica }\end{array}$ & $\begin{array}{l}\text { ao Aumento do vol. } A \\
\text { ela de trab. em conse-du } \\
\text { qüencla da ass. téc. }\end{array}$ & $\begin{array}{l}\text { Aumento na pro } \\
\text { duşäo aposs a ass } \\
\text { técnica. }\end{array}$ \\
\hline $\begin{array}{lr}\text { Estrato } & 0-3 \\
\text { Agrovila } & 3 \\
\text { Estrato }\end{array}$ & 1 & - & - & 1 & - & - \\
\hline $\begin{array}{lr}\text { Estrato } & 3-6 \\
\text { Agrovila } & 1 \\
& 3 \\
& 6 \\
& 8 \\
& 8\end{array}$ & $\frac{1}{\frac{1}{3}}$ & $\begin{array}{c}\overline{1} \\
1 \\
2\end{array}$ & $\frac{\bar{Z}}{\frac{7}{3}}$ & $\begin{array}{l}1 \\
1 \\
1 \\
2\end{array}$ & $\frac{1}{\frac{1}{4}}$ & $\overline{\bar{z}}$ \\
\hline $\begin{array}{lr}\text { Estrato } & 0 \\
\text { Agrovila } & 4 \\
& 8 \\
& 9 \\
& 9 \\
& 10 \\
\end{array}$ & $\begin{array}{l}1 \\
1 \\
1 \\
2\end{array}$ & $\frac{1}{-1}$ & $\begin{array}{l}\overline{1} \\
2 \\
2\end{array}$ & $\underline{z}$ & $\begin{array}{l}2 \\
1 \\
1 \\
1\end{array}$ & $\frac{1}{1}$ \\
\hline $\begin{array}{lr}\text { Estrato } 10-15 \\
\text { Agrovila } & 4 \\
& 6 \\
& 8 \\
& 9 \\
& 10 \\
\end{array}$ & $\begin{array}{l}\overline{-} \\
\overline{1} \\
1\end{array}$ & $\begin{array}{l}1 \\
1 \\
1 \\
1 \\
1 \\
\end{array}$ & $\begin{array}{l}- \\
1 \\
1 \\
1 \\
1 \\
\end{array}$ & $\begin{array}{c}\frac{1}{二} \\
1 \\
1\end{array}$ & $\begin{array}{l}1 \\
1 \\
1 \\
2 \\
2 \\
\end{array}$ & $\begin{array}{l}1 \\
1 \\
1 \\
-\end{array}$ \\
\hline $\begin{array}{lc}\text { Estrato } & 15+ \\
\text { Agrovila } & 9\end{array}$ & 3 & - & 2 & 1 & 2 & 1 \\
\hline Total & 15 & 11 & 14 & 12 & 19 & 7 \\
\hline
\end{tabular}

* Cinco questionários ficaram incompletos para esta seção.
Fonte: Pesquisa de Campo, PEC/SR, 1981 - CEPA-Ba.

Se compararmos o grupo de 10 a 15 ha com os estratos $0-3$ e 3-6, podemos ver que, nestes últimos, embora a maioria tenha sido influenciada pela Assistência Técnica na escolha de seu padrão de culturas, apenas uma minoria reconhece uma influência dela em relação ao modo de cultivar. No estrato de 10 a 15 ocorre o oposto, sendo minoritária a proporção dos agricultores dependentes da Assistência Técnica para mudanças nos sistemas de produção, e majoritária a proporção dos que indicam dependência no que tange a técnicas produtivas.

Isto sugeriria que, na fase inicial do emprego do crédito orientado, o impacto básico ocorre ao nível de mudanças nos sistemas de produção ou no próprio sistema de produção (em consonância com nossas colocações feitas acima), enquanto que, com maior envolvimento, tende-se à incorporação dos "pacotes tecnológicos", com sistemas de produção já definidos.

Além das pressões aumentadas sobre o processo de trabalho como um resultado da especialização e de influência da Assistência Técnica, observou-se que $80 \%$ dos usuários do crédito ampliaram sua área cultivada de um ano para o outro. Todas estas mudanças questionam a suficiência do trabalho familiar tradicional, e evidenciam a importância do trabalho nãofamiliar.

\subsection{Crédito e contratação de mão de obra}

$35 \%$ dos usuários do crédito admitiram empregar formas de ajuda mútua não-remunerada. No entanto, se decompusermos esta informação pelos estratos definidos pelo das áreas cultivadas, veremos que o emprego da ajuda mútua diminui à medida que aumenta o tamanho destas áreas. Nos estratos de 0-3 e 3-6 ha, a maioria declarou-se usuária da troca de trabalho, enquanto no estrato de 6-10 tais usuários são uma minoria, e virtualmente desapareceram no caso das duas maiores categorias de áreas cultivadas. Além disso, uma nítida maioria desses agricultores respondeu negativamente quando indagados se sabiam do emprego da ajuda mútua em outros lotes.

Pode-se verificar que a ajuda mútua, mesmo quando é comum, não tem um grande peso em termos do ciclo agrícola, se se examinam as respostas dadas à questão de ser a ajuda mútua considerada uma ocorrência ocasional ou uma parte regular das várias fases do ciclo agrícola.

Somente $45 \%$ dos entrevistados conseguiram responder a esta questão, e $50 \%$ deles declararam ser a ajuda mútua uma ocorrência ocasional. A maioria dos que a consideraram uma prática regular concentrase em uma agrovila (10).

Assim, um total aproximado de apenas $23 \%$ dos usuários do crédito consideraram a ajuda mútua uma prática regular que responde às necessidades das diferentes fases do ciclo agrícola; e estes, em sua maioria, pertencem aos estratos de menores áreas cultivadas, o que indica terem menor envolvimento com o crédito oficial.

$68 \%$ dos usuários de crédito declararam contratar mão de obra. Destes, $19 \%$ o fazem para todo o ciclo agrícola, $43 \%$ para fases específicas deles, e $48 \%$ apenas ocasionalmente. No que tange à forma de pagamento, predomina a remuneração salarial pura (68\%), quase sempre paga por dia.

Comparando estes resultados com os dados referentes aos nãousuários de crédito, vemos que apenas $32 \%$ destes declararam empregar trabalho assalariado. Portanto, a hipótese de que o crédito oficial é um 
importante fator condicionante de contratação de mão de obra obtém forte apoio a partir desses dados, que também confirmam a relação entre estes dois elementos (uso do crédito e contratação de trabalho) e o aumento na área cultivada. Reconhecendo a dificuldade de quantificar os dados no contexto de uma entrevista formal, elaboramos uma ampla gama de questões, visando a esclarecer melhor o significado do crédito para os pequenos produtores, e, especificamente, o impacto dele sobre a organização do processo de trabalho. Imaginamos que este método de aproximações sucessivas possa fornecer uma base mais sólida para a interpretação.

Se considerarmos as razões dadas pelos colonos para o uso de crédito, vemos que a compra de insumos modernos vem em primeiro lugar, acima da manutenção da família e contratação de mão de obra. Isto contrasta com a interpretação sugerida para o caso da pesquisa de Paraguaçu ${ }^{22}$ onde o crédito foi exclusivamente relacionado à contratação de mão de obra, e certamente reflete a maior penetração dos serviços de oferta de insumos e implementos, relacionada à assistência técnica, e em resultado da presença da Cooperativa no Projeto.

Nas respostas dadas a uma questão semelhante, porém referida ao uso de fato do crédito de custeio, discriminando os diferentes elementos do processo produtivo, a contratação de mão de obra assume o primeiro lugar, ao lado da manutenção da família.

A importância monetária do trabalho contratado é confirmada ainda mais significativamente quando considerarmos os custos de produção declarados pelos colonos, onde os salários constituem 68\% do total.

\subsection{Trabalho familiar $x$ não-familiar}

$\mathrm{Na}$ Tabela 28, a seguir, faz-se uma tentativa de quantificar a participação do trabalho assalariado em cada fase do ciclo agrícola. Embora seja necessário considerar estes números com a devida cautela, dadas as dificuldades de uma quantificação precisa, pode-se ver que o trabalho assalariado constitui um fator significativo em todos os estratos, exceto o de 10-15, e que sua importância se estende a todas as fases do ciclo agrícola. Particularmente significativa é a percentagem do trabalho assalariado na fase de Plantio-Tratos Culturais, refletindo a influência do pacote tecnol6gico da extensão rural e a absorção de insumos modernos. Isto contrasta com os dados sobre o emprego de trabalho assalariado pelos nãousuários de crédito, que s6 assume alguma importância na fase da colheita.

No caso do estrato de 15 ou mais ha, a mecanização é aparentemente o principal fator que limita o peso do trabalho assalariado nas fases de preparo do solo e de plantio (compare-se isto com os dois estratos mais baixos), pois todos os entrevistados deste estrato possuíam arados de tração animal.

Tabela 28 - Participação percentual do trabalho assalariado e familiar, segundo o

\begin{tabular}{|c|c|c|c|c|c|c|c|c|}
\hline \multirow{3}{*}{ Estrato } & \multirow{2}{*}{\multicolumn{2}{|c|}{ 0-6 (ha) }} & \multirow{2}{*}{\multicolumn{2}{|c|}{$\begin{array}{l}\text { e a fase do cic } \\
6-10 \text { (ha) }\end{array}$}} & & & & \\
\hline & & & & & \multicolumn{2}{|c|}{$10-15$ (ha) } & \multicolumn{2}{|c|}{15 ou + (ha) } \\
\hline & Fam. & Ass. & Fam. & Ass. & Fam. & Ass. & Fam. & Ass. \\
\hline $\begin{array}{l}\text { Prep. e } \\
\text { plantio }\end{array}$ & $76 \%$ & $24 \%$ & $74 \%$ & $26 \%$ & $98 \%$ & $2 \%$ & $82 \%$ & $18 \%$ \\
\hline $\begin{array}{l}\text { Tratos } \\
\text { culturais }\end{array}$ & $57 \%$ & $43 \%$ & $64 \%$ & $36 \%$ & $90 \%$ & $10 \%$ & $54 \%$ & $46 \%$ \\
\hline Colheita & $64 \%$ & $36 \%$ & $49 \%$ & $51 \%$ & $97 \%$ & $3 \%$ & $82 \%$ & $18 \%$ \\
\hline Total & 66 & 34 & 62 & 38 & 95 & 5 & 73 & 27 \\
\hline
\end{tabular}

Fonte: Pesquisa de Campo, - PEC/SR, CEPA-B

Esta explicação, contudo, não se aplica ao estrato de 10-15, onde apenas um colono tinha um arado de tração animal, e nenhum dos entrevistados alugava equipamentos de trabalho.

No entanto, observou-se que este estrato tinha uma proporção maior que a média de trabalhadores, crianças e adultos, por família (ver Tabela 29). Na realidade, os dados nesta Tabela subestimam a superioridade do trabalho familiar no estrato de 10 a 15 , pois, para o estrato de 6-10, a exclusão de uma única agrovila faria cair a média de trabalhadores nas famílias de 3,3 para 2, enquanto que a média maior do estrato de 10-15 vale para os representantes desse estrato em todas as agrovilas.

Assim, embora uma disponibilidade maior que a média de trabalho familiar possa permitir uma independência em relação ao trabalho assalariado, a importância deste último para todos os outros estratos, inclusive o de maior área cultivada, sugere que o trabalho exclusivamente familiar seja a exceção, e não a regra.

\footnotetext{
${ }^{22}$ Ver nossa análise da "Pesquisa da Unidade Produtiva" no Capítulo anterior.
} 
Tabela 29 - Número de trabalhadores familiares disponíveis por unidade (crianças e adultos), segundo o estrato e a fase do ciclo agrícola.

\begin{tabular}{c|c|c|c|c|c|c|c|c}
\multirow{2}{*}{$\begin{array}{c}\text { Fase do } \\
\text { ciclo } \\
\text { agrícola }\end{array}$} & \multicolumn{2}{|c|}{$0,6(\mathrm{ha})$} & \multicolumn{2}{c|}{$6-10(\mathrm{ha})$} & \multicolumn{2}{c|}{$10-15$ (há) } & \multicolumn{2}{c}{$15 \mathrm{ou}+(\mathrm{ha})$} \\
\cline { 2 - 9 } & Adulto & Criança & Adulto & Criança & Adulto & Criança & Adulto & Criança \\
\hline $\begin{array}{c}\text { Preparo do } \\
\text { solo e } \\
\text { plantio }\end{array}$ & 1,4 & 0,2 & 2,4 & 1,1 & 2,6 & 1,4 & 3,6 & 0,7 \\
\hline $\begin{array}{c}\text { Tratos } \\
\text { culturais }\end{array}$ & 0,9 & 0,2 & 2,5 & 1,1 & 2,6 & 1,4 & 3,0 & 0,7 \\
\hline Colheita & 1,4 & 0,2 & 2,3 & 0,6 & 2,9 & 1,4 & 3,0 & 0,7 \\
\hline $\begin{array}{c}\text { Média para } \\
\text { todo o ciclo }\end{array}$ & 1,1 & 0,2 & 2,4 & 0,9 & 2,7 & 1,4 & 3,2 & 0,7 \\
\hline & \multicolumn{2}{|c|}{1,3} & & \multicolumn{2}{|c|}{3,3} & \multicolumn{2}{c|}{4,1} & \multicolumn{2}{|c|}{3,9}
\end{tabular}

Fonte: Pesquisa de Campo, PEC/SR, 1981, CEPA-Ba

Ao invés de interpretar o emprego de trabalho assalariado como um expediente temporário para complementar a insuficiência do trabalho familiar disponível, ${ }^{23}$ dever-se-ia antes entender o trabalho familiar autossuficiente como no máximo o efeito de um equilíbrio conjuntural, dentro de uma dinâmica de produção determinada pela relação entre o crédito, preços de mercado e renda obtida.

Como vimos acima, existe um salto qualitativo na área cultivada pelos usuários do crédito oficial (equivalente ao dobro da cultivada pelos não-usuários desse crédito). Além disso, a área de plantio dos que usam o crédito mostra uma tendência para aumentar de um ano para o seguinte, tendência observada também no caso de Paraguaçu e, como veremos, válida igualmente para os usuários de crédito de Irecê.

Assim, embora os planos de produção possam coincidir com a disponibilidade de mão de obra familiar, a mudança para a produção comercial, causada pelo crédito oficial, produz uma tendência para o cultivo de uma área cada vez maior, possibilitado pelo componente-salário do crédito.

Em vista dos repetidos fracassos de safra (três em seis colheitas), pareceria que este aumento na área cultivada, ainda que certamente

\footnotetext{
${ }^{23}$ Como faz José Vicente Tavares dos Santos em seu livro Colonos do Vinho. Cf. nossos comentários no Capítulo Um.
}

estimulado por preços de mercado em alta (tanto a Cooperativa quanto os intermediários estavam comprando acima dos preços mínimos na época da nossa pesquisa), também é promovido pela necessidade de superar os custos de produção sempre crescentes, que aumentaram consideravelmente mais depressa que os preços dos produtos agrícolas. O compromisso de pagar o crédito oficial, num contexto de custos relativos de produção crescentes, explicaria então esta tendência de aumento de produção, que é relativamente independente dos preços correntes de mercado para os produtos agrícolas. Portanto, uma vez incorporada ao ciclo da produção subsidiada, a disponibilidade de trabalho familiar desempenha um papel significativamente menor na determinação dos planos de produção. Isso se vê claramente se compararmos os dados sobre o trabalho familiar na amostra de não-usuários de crédito.

Neste caso, o trabalho familiar tem um predomínio esmagador para todas as fases, e o trabalho assalariado só assume uma proporção significativa no período da colheita.

Mas, se o trabalho familiar não mais estabelece os limites da produção de cada lote, ele continua a constituir-se núcleo básico. Isto se vê claramente nas Tabelas 28 e 29, onde o trabalho familiar é nitidamente predominante; e mesmo no único caso em que o trabalho assalariado é de maior peso (a fase de colheita para o estrato de 6-10), isto não implicou uma substituição do trabalho familiar, uma vez que uma média de três membros por família também estava envolvida.

Vimos anteriormente que, para uma grande maioria dos chefes de família entrevistados (73\% - ver Tabela 27), o envolvimento com o crédito orientado representou um aumento no volume de trabalho. Assim, não houve tendência de emprego maior de trabalho assalariado passível de ser associada com a transformação do produtor direto em administrador.

Além disso, $73 \%$ dos entrevistados declararam que suas mulheres trabalhavam na lavoura, envolvidas, na grande maioria dos casos, em todas as fases do ciclo agrícola.

A porcentagem do trabalho infantil em proporção ao trabalho familiar total pode ser vista na seguinte Tabela: 
Tabela 30 - Proporção do trabalho infantil sobre o familiar total (\%).

\begin{tabular}{c|c|c|c|c}
\multirow{2}{*}{ Fase do ciclo agrícola } & \multicolumn{4}{|c}{ Estrato } \\
\cline { 2 - 5 } & $0-6$ & $6-10$ & $10-15$ & $15 \mathrm{ou}+$ \\
\hline Preparo e plantio & $17 \%$ & $40 \%$ & $35 \%$ & $4 \%$ \\
\hline Tratos culturais & $39 \%$ & $27 \%$ & $23 \%$ & $15 \%$ \\
\hline Colheita & $12 \%$ & $34 \%$ & $38 \%$ & $7 \%$ \\
\hline \multirow{2}{*}{$\begin{array}{c}\text { Média total } \\
\text { Fonte: } \text { Pesquisa de Campo, PEC/SR, 1981, CEPA-Ba. }\end{array}$} & $23 \%$ & $34 \%$ & $32 \%$ & $9 \%$
\end{tabular}

Fonte: Pesquisa de Campo, PEC/SR, 1981, CEPA-Ba.

Esta percentagem é calculada com base no número absoluto de dias de trabalho, sem uma ponderação da produtividade do trabalho adulto comparado ao infantil, e portanto superestima a contribuição quantitativa deste último. $^{24}$

Aparentemente, a participação do trabalho infantil estaria declinando em resultado da ênfase à escolarização na estratégia de desenvolvimento integrado. Isto é o que sugere a declarada preferência pela contratação de trabalho ao invés de se tirarem as crianças da escola, tendo $67 \%$ se manifestado a favor da primeira alternativa.

Porém, esta informação é conflitante com a obtida em entrevistas com os professores, nas quais se declarou ser elevado o absenteísmo nos períodos de pico do ciclo agrícola. Mesmo assim, o fato de que a maioria dos entrevistados tenha declarado que contratariam trabalho indica tanto um contexto em que o trabalho assalariado é prontamente empregado, quanto pelo menos uma relutância em admitir um prejuízo à educação das crianças, que pode ser um primeiro passo em direção a um declínio na participação do trabalho infantil na estrutura do trabalho familiar.

Por enquanto, o trabalho infantil continua a ser um elemento constitutivo do trabalho familiar, e sua eliminação progressiva pelas prioridades educacionais da estratégia de desenvolvimento integrado implicaria uma séria crise para a unidade familiar, levando a uma dependência ainda maior do trabalho contratado. ${ }^{25}$

\footnotetext{
${ }^{24}$ No entanto, as percentagens para o período de colheita podem estar subestimadas, em vista dos constantes fracassos de safra.

${ }^{25}$ Com relação à educação rural, estão-se fazendo tentativas para ajustar o currículo escolar ao ritmo do ciclo agrícola. Porém, isto levanta a questão de se dever ou não incentivar o trabalho infantil no contexto destes programas de modernização.
}

Diríamos então que, na medida em que a dependência do trabalho assalariado não substitui o trabalho familiar, e pode até ser vista como um reflexo do emprego intensificado deste, não existe base para se encarar este processo como sendo de "capitalização" do pequeno produtor, entendida como sua transformação num capitalista de pequena escala, da mesma forma como não se pode falar de uma capitalização dos produtores de Paraguaçu, conforme argumentamos no capítulo anterior. ${ }^{26}$

Na verdade, esta dependência de trabalho assalariado é um produto da crescente subordinação do trabalho familiar ao circuito dos capitais financeiro e industrial, que é, como veremos, independente da acumulação conseguida pela unidade produtiva.

Assim, a integração ao crédito oficial, pelo menos em sua primeira fase, cria um novo tipo de unidade produtiva agrícola mista, onde ambos os componentes estão subordinados, como veremos mais adiante, a um processo de acumulação essencialmente realizado fora da unidade agrícola, em benefício de uma ampla gama de capitais, que vão do mercantil tradicional ao moderno capital financeiro, mas tendendo a beneficiar sobretudo os capitais agroindustriais.

Além disso, a natureza da produção subordinada ao crédito, embora abra caminho e mesmo exija o emprego do trabalho assalariado, ao mesmo tempo impõe limites estruturais ao grau de incorporação deste.

Como vimos acima, o crédito cedido é calculado em termos dos insumos requeridos por produto/área financiados, sendo a componentetrabalho calculada numa base de homens-dia por fase do ciclo agrícola.

Contudo, é este elemento que, além de permitir a contratação de mão de obra, tem de garantir o sustento da família durante o ciclo agrícola. Assim, embora o crédito cedido seja calculado unicamente em termos de trabalho produtivo, ele tem de assegurar primeiramente a reprodução da unidade familiar como um todo, incluindo, além do trabalhador agrícola produtivo, tanto os consumidores não-produtivos (crianças, velhos e enfermos) quanto os trabalhadores "não-produtivo" (envolvidos em trabalho doméstico e em atividades fora do lote). Os limites do trabalho

\footnotetext{
${ }^{26}$ Pesquisa da Unidade Produtiva, Unidade Técnica POLONORDESTE, Paraguaçu, 1981.
} 
assalariado são definidos portanto pela diferença entre o empréstimo obtido e a soma necessária para a reprodução da família.

Na prática, este limite é elástico, pois tanto os custos da manutenção familiar quanto os gastos com outros insumos podem ser sacrificados para se contratar mão de obra, embora, por outro lado, o preço desta estivesse muito acima (153\%) do considerado nas alocações do crédito a este item pelo banco. ${ }^{27}$ Então podemos dizer que o limite superior para a contratação de trabalho é estabelecido pelas máximas condições toleráveis de autoexploração do colono e sua família. Esta conclusão indica o inverso de um suposto processo de "capitalização". Além disso, o emprego ótimo do crédito levará a uma crescente orientação do trabalho familiar para fins produtivos, que limitará mais ainda a instauração de uma agricultura essencialmente baseada em trabalho assalariado.

No entanto, poder-se-ia argumentar que os custos da manutenção da família são relativamente inelásticos, e que grandes empréstimos poderiam tanto satisfazer o consumo quanto abrir a possibilidade de uma agricultura predominantemente baseada em trabalho assalariado.

Tal hipótese, ainda que teoricamente possível, é excluída na prática pelo caráter subdesenvolvido no mercado de trabalho, que toma a oferta de mão de obra demasiado imprevisível para servir como base predominante dos planos de produção. Além do mais, as áreas necessárias para uma agricultura viável nestas bases excederiam o tamanho dos lotes dos colonos, e os riscos envolvidos frente a uma safra mal-sucedida aumentariam enormemente.

Deste modo, a produção subsidiada pelos créditos oficiais tende a produzir simultaneamente uma dependência estrutural de trabalho assalariado e uma intensificação do trabalho familiar, a qual, por sua vez, estabelece um limite para o grau em que o trabalho contratado é incorporado ao ciclo de produção. Contudo, embora seja errôneo identificar qualquer tendência de capitalização do pequeno produtor, isto não significa que o produtor direto e o trabalhador assalariado possam ser vistos simplesmente como elementos complementares, ou mesmo intercambiáveis, no interior do mesmo processo de produção misto. ${ }^{27}$ O salário médio pago pelos entrevistados era de $\mathrm{Cr} \$ 230$, embora a componente
"contratação de trabalho" de crédito considerasse um salário de apenas $\mathrm{Cr} \$ 150$.
Quando indagados sobre a natureza do trabalho contratado, a maioria dos colonos (52\%) considerou difícil o seu recrutamento. $86 \%$ identificaram os trabalhadores contratados como colonos com lotes de terra, e numa questão aberta sobre as principais razões para empregar-se enquanto assalariado, a falta de recursos para o plantio e a necessidade de fundos para a manutenção da família corresponderam a $81 \%$ das respostas. Só uma pessoa sugeriu que isto era uma prática normal, e duas que se empregavam principalmente por razões afetivas.

Fica claro, então, que o trabalho assalariado em lotes alheios não é visto como um modo de complementar a produção agrícola, mas sim como uma opção forçada de colonos com recursos insuficientes para plantar ou sustentar a família. Tal trabalho é portanto encarado como uma alternativa para os que não conseguem cultivar sua própria terra.

Apenas $10 \%$ dos entrevistados afirmaram ter trabalhado em outros lotes durante o ano anterior. Embora se esperasse uma proporção muito maior entre os não-usuários do crédito oficial, somente $15 \%$ deles declararam haver trabalhado em terras alheias no ano precedente.

Pode ser que haja uma certa relutância em se admitir um status de assalariado no contexto do programa de colonização, onde as famílias devem candidatar-se com base em sua disposição e capacidade de cultivar seu próprio lote.

No entanto, entrevistas com técnicos da extensão rural e colonos das agrovilas mais avançadas (em termos de recursos ao crédito e de área cultivada) indicaram que o grosso da oferta de mão de obra proveio de recém-chegados, que não tinham tido tempo de preparar sua terra nem de conseguir crédito. Nos períodos de atividade agrícola mais intensa, estes colonos passariam a semana trabalhando nas agrovilas onde há uma elevada demanda de mão de obra, voltando a suas próprias agrovilas somente nos fins-de-semana.

Desse modo, parece que, para a maioria dos não-usuários do crédito oficial, a renda proveniente da comercialização de produtos não-agrícolas (ver acima a discussão sobre a importância da madeira e do pequeno comércio de mantimentos) e outros rendimentos obtidos fora do lote (envolvendo 17\% dos entrevistados), além de uma acomodação a níveis de 
subsistência inferiores, predominavam sobre o trabalho agrícola assalariado enquanto base para a sobrevivência.

Tabela 31 - Caracterização do trabalho assalariado no PEC/SR

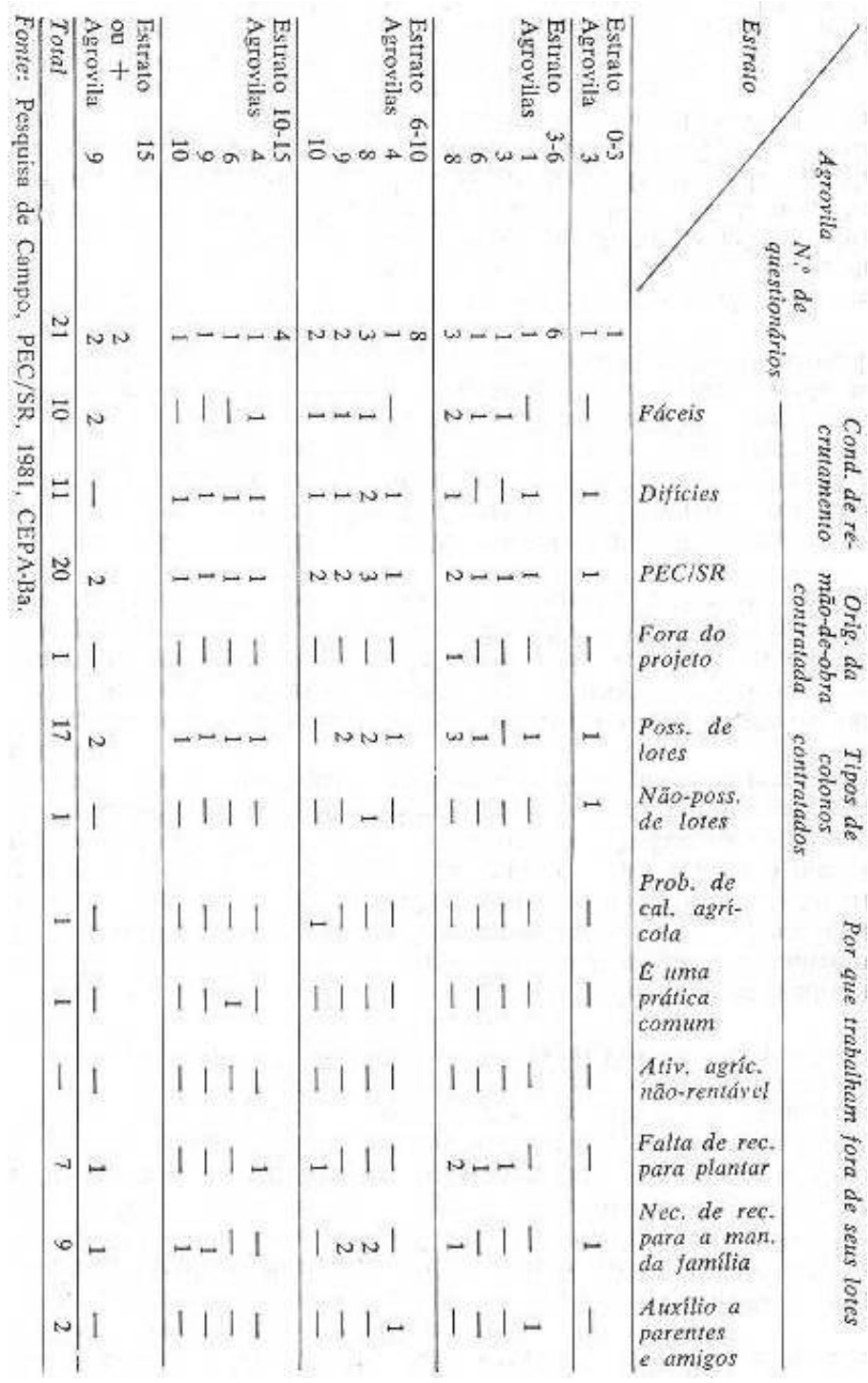

Embora a demanda por trabalho assalariado seja generalizada entre os usuários do crédito oficial, e se mantenha para todas as fases do ciclo agrícola, a oferta é limitada e predominantemente temporária.

\subsection{Crédito, tecnificação e renda agrícola}

O efeito da adoção dos equipamentos e implementos agrícolas sobre a demanda de mão de obra, tal como aparece nas respostas a questões sobre esse tema, sugere que o colono, embora cada vez mais dependente do assalariado, não encara o emprego deste último como uma forma natural de suprimento de trabalho.

$65 \%$ dos entrevistados tinham comprado equipamentos e/ou implementos agrícolas. Quando indagados sobre os efeitos dessas aquisições sobre o emprego de trabalho, todos disseram que elas diminuíam a necessidade de contratar mão de obra, especialmente na fase de plantio. A ênfase maior para este período resulta, provavelmente, não tanto de seu caráter especialmente trabalho-intensivo, mas do fato de que faltam equipamentos aplicáveis às outras fases, particularmente à fase de colheita, que continua manual, como consequência do predomínio das lavouras consorciadas.

Em resposta a uma questão aberta sobre a preferência por tração animal ou mecânica, uma nítida maioria declarou-se favorável à última (74\%), por motivos compatíveis com a necessidade de economizar trabalho em $88 \%$ dos casos ("torna o serviço mais fácil", 29\%; "torna o serviço mais rápido", 35\%; "substitui mão de obra", 24\%).

Além disso, $85 \%$ das respostas à questão "Você gostaria de adquirir instrumentos de trabalho?" foram afirmativas, tendo $82 \%$ delas indicado uma preferência por tração animal (36\%) ou mecânica $(45 \%)$, e com a maioria (55\%) justificando a afirmativa com o argumento de que tal aquisição diminuiria as necessidades de trabalho.

Podemos assim detectar o início de uma tendência de se substituir mão de obra, particularmente a assalariada, por formas de mecanização, tendência esta que pode ser entendida como refletindo uma tentativa de se recuperar o domínio exclusivo do processo de trabalho pela estrutura familiar. 
Aqui, mais uma vez, o emprego de trabalho assalariado, mais que um salto em direção a uma agricultura capitalista de pequena escala, pareceria representar um fator de restrição, a ser superado pelo incremento da produtividade do trabalho familiar com a mecanização.

Tal interpretação é reforçada quando se reconhece que esta mudança para a mecanização é financiada, principalmente, por um maior recurso ao crédito oficial, com todos os riscos que cercam o endividamento aumentado.

Dos 26 animais que os colonos afirmaram possuir, 19 (75\%) tinham sido total ou parcialmente financiados pelo crédito, enquanto $9(35 \%)$ haviam sido custeados por rendimentos provenientes da venda de produtos das safras.

A Tabela 32 contém dados sobre a aquisição de equipamentos e implementos. Como se pode ver, no caso dos equipamentos, o crédito continua a prevalecer; a renda obtida nas safras e as aquisições prévias só adquirem uma importância maior no caso dos implementos agrícolas básicos.

Tabela 32 - Discriminação dos equipamentos e implementos agrícolas segundo a origem dos recursos para sua aquisição.

\begin{tabular}{c|c|c|c|c}
\multirow{2}{*}{$\begin{array}{c}\text { Equipamentos e } \\
\text { Implementos }\end{array}$} & Quantidade & $\begin{array}{c}\text { Antes da } \\
\text { colon. }\end{array}$ & Safra & Crédito \\
\cline { 2 - 5 } & \multicolumn{4}{|c}{ 1. Equipamentos } \\
\hline $\begin{array}{c}\text { Plantadeiras } \\
\text { mecânicas }\end{array}$ & 40 & 4 & 7 & 7 \\
\hline $\begin{array}{c}\text { Bombas } \\
\text { hidráulicas }\end{array}$ & 9 & 0 & 0 & 4 \\
\hline $\begin{array}{c}\text { Carroças } \\
\text { puxada a cavalo }\end{array}$ & 17 & 0 & 2 & 15 \\
\hline $\begin{array}{c}\text { Máquinas } \\
\text { benef. de arroz }\end{array}$ & 2 & 0 & 1 & 1 \\
\hline $\begin{array}{c}\text { Pulverizadores } \\
\text { manuais }\end{array}$ & 8 & 0 & 3 & 1 \\
\hline $\begin{array}{c}\text { Pulverizadores } \\
\text { mec. }\end{array}$ & 1 & 0 & 0 & 31 \\
\hline Subtotal & & 4 & 13 & 3 \\
\hline
\end{tabular}

2. Implementos

\begin{tabular}{c|c|c|c|c}
\hline \multicolumn{7}{|c}{ 2. Implementos } \\
\hline $\begin{array}{c}\text { Carrinho de } \\
\text { mão }\end{array}$ & 1 & 0 & 1 & 0 \\
\hline Enxada & 101 & 11 & 15 & 4 \\
\hline Foices & 64 & 12 & 14 & 5 \\
\hline Facões & 26 & 8 & 8 & 6 \\
\hline Subtotal & & 31 & 38 & 15
\end{tabular}

Fonte: Pesquisa de Campo. PEC/SR. 1981. CEPA-Ba.

Esta dependência de crédito para investimento estende-se às benfeitorias agrícolas:

Tabela 33 - Benfeitorias agrícolas e recursos para sua instalação

\begin{tabular}{c|c|c|c|c}
\multirow{2}{*}{$\begin{array}{c}\text { Benfeitorias } \\
\text { agrícolas }\end{array}$} & Quantidade & $\begin{array}{c}\text { Antes da } \\
\text { colon. }\end{array}$ & Safra & Crédito \\
\cline { 2 - 5 } & 1 & 0 & 0 & 1 \\
\hline $\begin{array}{c}\text { Casas de } \\
\text { farinha }\end{array}$ & 1 & 0 & 2 & 1 \\
\hline Armazéns & 3 & 2 & 5 & 13 \\
\hline Cercas & 19 & 0 & 0 & 2 \\
\hline Poços & 2 & 0 & 4 & 19
\end{tabular}

Fonte: Pesquisa de Campo, PEC/SR, 1981, CEPA/Ba

As peculiaridades da produção subsidiada pelo crédito oficial mostram-se agudas, quando consideramos a renda gerada pela produção agrícola nos lotes. Como vimos, são características de nossa amostra as tendências tanto para uma expansão na produção quanto para uma tecnificação da unidade agrícola. Este quadro, porém, contrasta fortemente com os dados referentes aos rendimentos obtidos nas safras.

Apenas $17 \%$ dos entrevistados tiveram um retomo na safra superior aos custos de produção, e, entre estes, a renda média anual obtida foi um pouco inferior a um salário mínimo por família. As perdas médias para os $83 \%$ que não conseguiram retornos positivos foram da ordem de 24 salários mínimos regionais. Embora nesse ano a colheita tenha sido excepcionalmente má, não se deve esquecer que três das seis colheitas efetuadas desde o início do projeto tinham sido generalizadamente malsucedidas. 
Contudo, para fazermos uma ideia mais realista da renda agrícola potencial de um lote típico do usuário de crédito, calculamos a renda líquida, após o pagamento do crédito, para 7 hectares colhidos $(3$ de arroz e 4 de milho com mamona, que são as culturas predominantes no projeto etc.), usando a produtividade média alcançada na safra anterior, os preços de compra da Cooperativa e os Orçamentos do Crédito da Extensão Rural (veja Tabela 34).

Tabela 34 - Renda agrícola do colono típico, baseada em 7 hectares cultivados com arroz (3 ha) e milho com mamona (4 ha), considerando-se os cálculos de produtividade da extensão rural, e os preços pagos pela cooperativa em 1980/81.

\begin{tabular}{|c|c|c|c|c|c|}
\hline \multirow[b]{2}{*}{ Produtos } & \multirow[b]{2}{*}{$\begin{array}{l}\text { Crédito cedido, } \\
\text { com base no } \\
\text { orçamento da ext. } \\
\text { rural }\end{array}$} & \multicolumn{2}{|c|}{ Preços de venda } & \multicolumn{2}{|c|}{ Renda } \\
\hline & & $\begin{array}{l}\text { Produtivid } \\
\text { ade. por } \\
\text { ha }\end{array}$ & $\begin{array}{l}\text { Preços } \\
\text { da } \\
\text { coopera } \\
\text { tiva }\end{array}$ & $\begin{array}{l}\text { Preço } \\
\text { total da } \\
\text { safra }\end{array}$ & $\begin{array}{c}\text { Preço } \\
\text { total da } \\
\text { safra - } \\
\text { crédito } \\
\text { obtido }\end{array}$ \\
\hline Milho & $\begin{array}{c}\text { Cr\$ } 10.370 \times 3= \\
\$ 31.110\end{array}$ & $1.656 \mathrm{~kg}$ & $\begin{array}{l}\mathrm{Cr} \$ 800 \\
\mathrm{p} / 50 \mathrm{~kg}\end{array}$ & $\begin{array}{c}\text { Cr\$79.20 } \\
0\end{array}$ & $\begin{array}{c}\text { Cr\$48.09 } \\
0 \\
\end{array}$ \\
\hline Arroz & $\begin{array}{c}\mathrm{Cr} \$ 4.507 \times 4= \\
\$ 18.028\end{array}$ & $510 \mathrm{~kg}$ & $\begin{array}{l}\mathrm{Cr} \$ 750 \\
\mathrm{p} / 60 \mathrm{~kg}\end{array}$ & $\begin{array}{c}\mathrm{Cr} \$ 25.50 \\
0\end{array}$ & $\mathrm{Cr} \$ 7.472$ \\
\hline Mamona & $\begin{array}{c}\mathrm{Cr} \$ 4.507 \times 4= \\
\quad \$ 18.028\end{array}$ & $613 \mathrm{~kg}$ & $\begin{array}{c}\mathrm{Cr} \$ \\
1.380 \mathrm{p} / \\
60 \mathrm{~kg}\end{array}$ & $\begin{array}{c}\text { Cr } \$ 56.30 \\
4\end{array}$ & $\begin{array}{c}\mathrm{Cr} \$ 38.27 \\
6\end{array}$ \\
\hline
\end{tabular}

De acordo com estes cálculos, a renda líquida anual do lote seria de cerca de Cr\$ 93.838. Deste total, no entanto, devem-se deduzir os juros sobre o crédito, ${ }^{28}$ que, a $10 \%$, seriam de $\mathrm{Cr} \$ 6.717$, e a primeira prestação do crédito de investimento, que em 1980/81 foi, em média, de Cr\$33.864, por usuário de crédito no projeto como um todo.

Normalmente, o crédito de investimento deve ser pago em três prestações, a partir da safra seguinte. f: preciso então deduzir mais Cr\$ 11.288 , o que dá uma renda líquida anual de Cr\$75.833 substancialmente menor que um salário mínimo mensal por família.

\footnotetext{
${ }^{28}$ Tais juros são porém muitas vezes deduzidos antecipadamente, o que torna a manutenção dos planos de produção difícil.
}

Mesmo se dobrássemos esta renda, para considerar os que cultivam as maiores áreas, o total seria ainda inferior a um salário mínimo por trabalhador adulto em cada unidade familiar. Em termos de um salário por dia, isso significa que o trabalhador da família recebe substancialmente menos que o assalariado que ele contrata. ${ }^{29}$

Assim, fica claro que a dinâmica de produção que observamos ao longo de toda a nossa análise (aumento na área cultivada, contratação de trabalho, tecnificação) não guarda relação alguma com a acumulação agrícola, e é completamente dependente dos mecanismos do crédito subsidiado.

Uma vívida confirmação desta tese é fornecida pelos dados sobre a safra de 1981/83, que prevêem um total de Cr\$300.000.000, para o crédito de custeio. Isto representa um aumento de $300 \%$ em relação ao ano anterior, a despeito dos fracassos generalizados de colheitas.

\section{Conclusão}

Neste Capítulo, aproveitando as condições de laboratório oferecidas pelo Projeto de Colonização de Serra do Ramalho, pudemos explorar o impacto da integração ao crédito oficial sobre o processo de trabalho da agricultura familiar. Ao fazê-lo, conseguimos determinar o papel estrutural, embora subordinado, da contratação de mão de obra, que é uma consequência da intensificação simultânea do trabalho familiar.

A contratação de trabalho não pode ser encarada como uma transição a uma agricultura capitalista em pequena escala no interior do Projeto. $\mathrm{Na}$ realidade, o colono procura recuperar o controle familiar sobre o processo de trabalho eliminando o trabalho assalariado em favor da mecanização, que é ao mesmo tempo estimulada pelas crescentes demandas da produção orientada pela extensão rural.

Além disso, os aumentos de produção e o maior consumo de produtos agroindustriais (sementes selecionadas, fertilizantes, defensivos), mais as tendências de mecanização, longe de refletirem um processo de acumulação agrícola, podem ser sustentados a uma remuneração igualou

${ }^{29}$ Embora a Extensão Rural calculasse o salário de um homem/dia como sendo de Cr\$150, o valor médio deste salário, com base no estudo de campo, era de Cr\$250. 
inferior ao salário mínimo, pelo mecanismo da produção subsidiada através do crédito oficial.

No caso de Paraguaçu, nossa análise mostrou que, embora estivessem presentes elementos de um mesmo processo, a estrutura latifundiária bloqueava amplamente o seu desenvolvimento.

No Capítulo seguinte, analisaremos um programa de modernização de pequenos produtores num contexto onde a produção comercial de alimentos é também o sistema dominante de produção de propriedades médias e grandes, e onde os níveis de mecanização são mais elevados que no exemplo do Projeto de Serra do Ramalho. Esperamos poder demonstrar mais claramente com este exemplo a natureza das contradições provocadas pela modernização do pequeno agricultor tradicional.
Capítulo seis - Irecê: um caso avançado de modernização

\section{Padrões de ocupação e características enquanto zona produtora de} alimentos

Se o Projeto de Colonização PEC/SR oferecia condições artificiais particularmente favoráveis para a análise da modernização da agricultura tradicional em pequena escala, Irecê fornece o melhor exemplo proveniente da estrutura socioeconômica do Nordeste.

Num padrão diferente do que se encontra por todo o Nordeste, em Irecê as condições para a produção comercial de culturas alimentares pelo setor agrícola de pequena escala são melhoradas pelo envolvimento análogo de médias e grandes propriedades, que garantiu a concentração de benfeitorias infraestruturais (particularmente estradas asfaltadas ligando a área aos maiores mercados urbanos) e serviços (rede bancária, instalações para armazenagem, serviços de expansão rural), além da forte presença de capitais agroindustriais na área (indústrias de transformação, revendedores de equipamentos e maquinaria agrícolas).

Enquanto o setor minifundiário, como subproduto do latifúndio, teve tradicionalmente seu espaço predeterminado pelas dimensões e demandas do sistema de produção dominante, a ocupação da região de Irecê teve as características de uma situação de fronteira. Como resultado, o setor de pequena produção que surgiu não foi primariamente uma reserva de mão de obra, mas assumiu uma postura típica de agricultura em pequena escala, cuja reprodução é dependente da renda agrícola.

Isto se refletiu no tamanho médio destas propriedades. Em 1950 (ver Tabela 35), de 1.191 propriedades no município de Irecê, 1.026 (86\%) tinham menos de 50 hectares. Destas, porém, apenas 136 tinham menos de 5 ha $(13 \%)$, com uma média de 15 ha para o estrato de 0 a 50 como um todo.

Irecê enquadra-se bem na análise de sistemas de produção sintetizada no Capítulo Três. Antes de sua ocupação pela pequena produção agrícola nos anos 40 a área formava parte de uma vasta zona de criação extensiva de gado. Tal pecuária tradicionalmente ocupou grandes áreas, dando lugar à produção agrícola em bolsões de elevada fertilidade do solo ou condições 
climáticas favoráveis, formando assim um sistema de produção combinando pecuária e agricultura diversificada, e provendo condições para a emergência da produção especializada de gêneros alimentícios.

Tabela 35 - Número e área dos estabelecimentos segundo o tamanho do estrato município de Irecê - 1950/1960/1970/1975

\begin{tabular}{|c|c|c|c|c|c|c|c|c|}
\hline \multicolumn{5}{|c|}{1950} & \multicolumn{4}{|c|}{1960} \\
\hline \multirow{2}{*}{$\begin{array}{c}\text { Estrato } \\
\text { de área } \\
(\text { há })\end{array}$} & \multicolumn{2}{|c|}{ Estabelecimentos } & \multicolumn{2}{|c|}{ Área (ha) } & \multicolumn{2}{|c|}{ Estabelecimentos } & \multicolumn{2}{|c|}{ Área (ha) } \\
\hline & $\mathrm{Ha}$ & $\%$ & $\mathrm{Ha}$ & $\%$ & $\mathrm{Ha}$ & $\%$ & $\mathrm{Ha}$ & $\%$ \\
\hline 1 & 1 & 0,08 & - & - & 3 & 0,13 & 3 & 0,00 \\
\hline $1-2$ & 1 & 0,08 & 1 & 0,00 & 9 & 0,37 & 13 & 0,01 \\
\hline $2-5$ & 135 & 11,34 & 556 & 1,17 & 131 & 5,43 & 493 & 0,27 \\
\hline $5-10$ & 263 & 22,08 & 1.985 & 4,17 & 332 & 13,77 & 2.663 & 1,40 \\
\hline $10-20$ & 341 & 28,63 & 4.859 & 10,22 & 421 & 17,46 & 6.117 & 3,22 \\
\hline $20-50$ & 285 & 23,94 & 8.454 & 17,78 & 686 & 28,46 & 22.589 & 11,90 \\
\hline $\begin{array}{c}\text { Subtotal } \\
(A)\end{array}$ & 1.026 & 86,15 & 15.855 & 33,34 & 1.582 & 65,62 & 31.878 & 16,80 \\
\hline $50-100$ & 81 & 6,80 & 5.752 & 12,09 & 347 & 14,39 & 26.111 & 13,76 \\
\hline $100-200$ & 44 & 3,69 & 6.113 & 12,85 & 230 & 9,54 & 32.679 & 17,22 \\
\hline $200-500$ & 33 & 2,77 & 10914 & 22,95 & 207 & 8,59 & 61.197 & 32,25 \\
\hline $\begin{array}{c}500- \\
1.000 \\
\end{array}$ & 5 & 0,42 & 3.788 & 7,96 & 31 & 1,28 & 20.207 & 10,65 \\
\hline $\begin{array}{c}1.000 \mathrm{e} \\
\text { mais }\end{array}$ & 2 & 0,17 & 5.139 & 10,81 & 14 & 0,58 & 17.687 & 9,32 \\
\hline $\begin{array}{c}\text { Subtotal } \\
(B)\end{array}$ & 165 & 13,85 & 31.706 & 66,66 & 829 & 34,38 & 157.886 & 83,20 \\
\hline $\begin{array}{c}\text { Total } \\
\text { Geral }\end{array}$ & 1.191 & 100,00 & 47.561 & 100,00 & 2.411 & 100,00 & 189.764 & 100,00 \\
\hline
\end{tabular}

Tabela 35 (continuação) - Número e área dos estabelecimentos segundo o tamanho do estrato - município de Irecê - 1950/1960/1970/1975

\begin{tabular}{|c|c|c|c|c|c|c|c|c|}
\hline \multicolumn{5}{|c|}{1970} & \multicolumn{4}{|c|}{1975} \\
\hline \multirow{2}{*}{$\begin{array}{c}\text { Estrato } \\
\text { de área } \\
(\text { ha })\end{array}$} & \multicolumn{2}{|c|}{ Estabelecimentos } & \multicolumn{2}{|c|}{ Área (ha) } & \multicolumn{2}{|c|}{ Estabelecimentos } & \multicolumn{2}{|c|}{ Área (ha) } \\
\hline & $\mathrm{Ha}$ & $\%$ & $\mathrm{Ha}$ & $\%$ & $\mathrm{Ha}$ & $\%$ & $\mathrm{Ha}$ & $\%$ \\
\hline 1 & 47 & 0,91 & 32 & 0,01 & 9 & 0,23 & 8 & 0,00 \\
\hline $1-2$ & 108 & 2,09 & 164 & 0,07 & 27 & 0,69 & 45 & 0,02 \\
\hline $2-5$ & 901 & 17,43 & 3.205 & 1,30 & 506 & 12,97 & 1.859 & 0,75 \\
\hline $5-10$ & 982 & 18,99 & 7.041 & 2,87 & 649 & 16,64 & 4.696 & 1,90 \\
\hline $10-20$ & 798 & 15,44 & 11.425 & 4,66 & 653 & 16,74 & 9.361 & 3,79 \\
\hline $20-50$ & 1.169 & 22,61 & 37.858 & 15,43 & 930 & 23,84 & 31.046 & 12,58 \\
\hline $\begin{array}{c}\text { Subtotal } \\
\text { (A) }\end{array}$ & 4.005 & 77,47 & 59.725 & 24,34 & 2.774 & 71,11 & 47.015 & 19,04 \\
\hline $50-100$ & 559 & 10,81 & 40.232 & 16,40 & 479 & 12,28 & 34.377 & 13,92 \\
\hline $100-200$ & 368 & 7,12 & 50.694 & 20,66 & 347 & 8,90 & 47.738 & 19,33 \\
\hline $200-500$ & 200 & 3,87 & 59.711 & 24,33 & 251 & 6,43 & 76.155 & 30,84 \\
\hline $\begin{array}{c}500- \\
1.000 \\
\end{array}$ & 30 & 0,58 & 21.011 & 8,56 & 38 & 0,97 & 24.346 & 9,86 \\
\hline $\begin{array}{c}1.000 \mathrm{e} \\
\text { mais }\end{array}$ & 8 & 0,15 & 14.023 & 5,71 & 12 & 0,31 & 17.299 & 7,01 \\
\hline $\begin{array}{c}\text { Subtotal } \\
\text { (B) }\end{array}$ & 1.165 & 22,53 & 185.671 & 75,66 & 1.127 & 28,89 & 199.915 & 80,96 \\
\hline $\begin{array}{l}\text { Total } \\
\text { Geral }\end{array}$ & 5.170 & 100,00 & 245.396 & 100,00 & 3.901 & 100,00 & 246.930 & 100,00 \\
\hline
\end{tabular}

Irecê, com sua grande chapada de terra altamente fértil, cedo formou um oásis de produção agrícola no sertão baiano. No entanto, embora a ocupação desta área tivesse sido espontânea, sua consolidação foi conseguida através da produção de algodão e, principalmente, mamona para 
exportação, controlada pelos maiores capitais comerciais e agroindustriais da região.

O potencial particular desta região (composta de terrenos excepcionalmente planos e férteis), e a importância conjuntural da mamona, fizeram-na o objeto privilegiado de intervenção do então recentemente formado organismo federal "Comissão para o Vale do São Francisco", levando à concentração de tratores e técnicos de extensão rural na área, transformando rapidamente Irecê no segundo município mais mecanizado do Estado. ${ }^{3}$

Mas, embora a mamona tenha continuado a ser um elemento básico da produção agrícola desta região, sua persistência deveu-se à sua capacidade de integração a uma produção agrícola predominantemente alimentar, baseada no cultivo consorciado de feijão, milho e mamona.

Esta predominância de culturas alimentares ocorreu lado a lado com a explosão do mercado urbano para gêneros alimentícios básicos nos anos 50

O grau da dependência urbana para com esta região no abastecimento de feijão e milho foi expresso pela ligação inédita da área à capital do Estado por meio de uma estrada asfaltada, conhecida como "Estrada do Feijão" (o que simboliza a subordinação da produção de produtos exportáveis à produção de alimentos para as capitais urbanas). A isto, seguiu-se a construção de uma rede rodoviária semelhante ligando a região às outras capitais do Nordeste.

A contribuição desta região para o abastecimento alimentar urbano do Nordeste, e a prioridade concedida à sua consolidação enquanto zona produtora de alimentos, desmentem os argumentos que analisam a evolução da oferta de gêneros alimentícios básicos exclusivamente em termos de expansão do setor minifundiário tradicional (ver discussão anterior sobre

\footnotetext{
${ }^{1}$ A família Coelho dominou a comercialização e beneficiamento do algodão, e era a maior força política e econômica tradicional na área do São Francisco que abrange Bahia e Pernambuco. A multinacional SANBRA dominou a industrialização e exportação da mamona.

${ }^{2}$ CVSF - criada no contexto de uma preocupação na época da Segunda Guerra Mundial, para o desenvolvimento como a base de integração e segurança nacional. A CVSF ficou responsável pelo desenvolvimento de toda a bacia do rio São Francisco.

${ }^{3}$ Ver o Censo Agrícola, Bahia 1960.
}

este tema nos Capítulos Um e Três). De acordo com uma pesquisa realizada pelo Centro Baiano de Abastecimento Alimentar, em 1973 cerca de 34\% do consumo de feijão em Salvador dependia de suprimentos provenientes desta única região, embora a maioria de sua produção fosse diretamente para outras capitais nordestinas. ${ }^{4}$

Assim, o surgimento desta zona especializada em produção alimentar era e continua a ser uma precondição para a estabilização da oferta de alimentos básicos para as capitais do Nordeste, em rápida expansão.

Embora a abertura desta região nos anos 40 tenha presenciado a consolidação predominantemente de um setor agrícola de pequena escala, a década seguinte testemunhou o espetacular avanço de médias e grandes propriedades em Irecê (ver Tabela 35).

Dos 142.203 novos hectares de terra incorporados, 126.180 ha couberam a fazendas de mais de 50 ha. No entanto, as principais beneficiários não foram "latifundiários" típicos (embora também estes tenham consolidado sua posição), mas proprietários na faixa de 50 a 500 ha, que ficaram com 97.213 ha, ou seja, $77 \%$ da nova terra apropriada pelo estrato de mais de 50 ha.

Como resultado, o número de propriedades acima de 50 ha aumentou em $502 \%$, subindo de $14 \%$ a $34 \%$ de todas as propriedades no município. Em contraste, as de menos de 50 ha aumentaram seu número em apenas $154 \%$, embora a área média tenha subido de 15 para 20 ha.

Nos anos 60, este padrão mudou substancialmente. As novas áreas incorporadas foram divididas igualmente entre os estratos de 0-50 e de mais de 50 ha. Contudo, embora o aumento numérico no estrato de 50 em diante fosse de apenas $140 \%$, e restrito ao grupo de 50-200 ha (com um declínio anual do latifúndio), no estrato de 0-50 o crescimento foi da ordem de $253 \%$; e, se considerarmos separadamente o estrato 0-5 ha, o crescimento foi muito maior $-738 \%$.

\footnotetext{
${ }^{4}$ Dados extraídos de Estudos sobre o abastecimento alimentar da Região Metropolitana de Salvador, SEPLANTEC, Bahia, (sem data). Este estudo sugere que tais dados exageram um pouco a participação de Irecê, opinião compartilhada pelo consultor da CEPA. Contudo, uma estimativa mais modesta indicaria $20-25 \%$, e portanto uma contribuição ainda decisiva para o abastecimento de feijão de Salvador.
} 
Parece então que nesta década, em consequência da maciça consolidação das médias propriedades nos dez anos anteriores, criou-se uma significativa camada de minifúndios, e sua reduzida área sugere que formaram primariamente uma reserva de mão de obra. Tal hipótese é fortalecida quando consideramos que a área média das propriedades pertencentes ao estrato de 10-50 ha permaneceu estável.

Pareceria então haver-se desenvolvido uma divisão no interior do estrato das pequenas propriedades, com a criação de um setor semiproletarizado, cuja reprodução dependeria essencialmente do crescente mercado para trabalho temporário.

Os dados de 1975 mostram mais uma mudança estrutural na ocupação da terra do município de Irecê. As novas terras incorporadas representam apenas $0,6 \%$ da terra total, indicando um fechamento da fronteira no município.

A expansão da área ocupada por estabelecimentos de mais de 50 hectares agora ocorre principalmente às custas das propriedades do estrato de 0-50 ha, que declinam enormemente tanto em termos numéricos (de 4.005 para 2.744) quanto de área total (59.725 para 47.015 ha). As mais afetadas estão na categoria de 0-5 hectares (diminuindo de 1.056 para 542), o que indica uma expulsão do setor de mão de obra de reserva para fora do município, rumo às áreas circunvizinhas.

Contudo, o processo de concentração, que nos anos 60 tinha favorecido o estrato de 50-200 ha, nos anos 70 torna-se esmagadoramente restrito ao grupo de 200-500 ha, tendo as propriedades maiores também aumentado seu quinhão. Nesta análise dos dados do Censo Agrícola, evidencia-se que, embora as pequenas propriedades (0-50) tenham permanecido claramente majoritárias - 71\% em 1975 elas tiveram um marcado declínio em número, já que nos anos 40 correspondiam a $86 \%$ da quantidade total. Este declínio assume a forma de uma crescente dominância de propriedades médias e grandes, cujo número sobe de uma proporção de $14 \%$ para 34\% de todas as propriedades entre 1950 e 1960.

Embora nos anos 60 o setor produtivo de pequena escala tenha recuperado um pouco de sua relativa predominância numérica $(77 \%)$, isto ocorreu principalmente com base num aumento das propriedades muito pequenas, que provavelmente constituíam mais uma reserva de mão de obra que um setor especificamente produtivo em pequena escala. Nos anos 70, a rápida valorização da terra, além das facilidades do crédito subsidiado, num contexto de fechamento da fronteira, levaram à crescente eliminação deste setor minifundiário e um declínio absoluto em todas as propriedades de menos de 200 ha. Assim, enquanto em 1950 a área ocupada pelo estrato de 0-50 ha era exatamente a metade da ocupada pelo grupo de mais de 50 ha, por volta de 1975 a parte que cabia ao primeiro correspondia a menos de um quarto.

Contudo, esta crescente predominância das fazendas médias e grandes não se refletiu nem num retorno à pecuária (que, na sub-região de Irecê, não representa mais de $15 \%$ do valor bruto da produção), ${ }^{5}$ nem numa mudança para outras culturas. O algodão, que é cultivado exclusivamente em propriedades médias para grandes e se concentra quase totalmente no município de Irecê, responde por menos de $10 \%$ da área cultivada em feijão.

Além disso, o município de Irecê contribuiu, durante este período, com mais da metade da produção total de feijão da microrregião.

Impõe-se portanto a conclusão de que as propriedades de mais de 50 ha contribuem substancialmente para a produção de alimentos básicos da região.

Isto se evidencia se comparamos a área colhida em 75 (e esta é quase sempre bem menor que a área cultivada) com a área total das propriedades no estrato de 0-50 ha. Esta última representa apenas 59\% da área colhida de feijão. Isto indicaria que mais da metade da produção de culturas alimentares veio de fazendas médias e grandes. Tal hipótese é confirmada pelo Cadastro do INCRA para 1972, que discrimina a área plantada segundo o estrato.

De acordo com estas cifras, $71 \%$ da produção viria de fazendas de mais de 50 ha. No entanto, duas ressalvas poderiam ser feitas aos dados do INCRA. Como as informações deste Instituto se baseiam em propriedades registradas, elas certamente subestimam a participação das propriedades menores, que nem sempre estão legalizadas. Mas isto aparentemente não afetaria seriamente a conclusão geral, pois os dados relativos à área total cultivada são semelhantes aos números do IBGE citados acima.

${ }^{5}$ Histórico do PDRI Irecê, - Unidade Técnica POLONORDESTE, Irecê, 1981. 
Em segundo lugar, os dados do INCRA dependem de uma caracterização jurídica da natureza de uma propriedade, e não consideram sua forma de ocupação. Assim, uma grande propriedade pode muito bem estar cultivada na base de múltiplas parcerias e arranjos de arrendamento, e aparecer nos dados como uma única fazenda.

De acordo com o Censo Agrícola para 1975, porém, a parceria e o arrendamento correspondiam a apenas uma pequena fração do total menos de $1 \%$-das propriedades.

A insignificância da parceria é contestada por uma pesquisa recente realizada na área pelo Centro de Pesquisas e Estudos, Bahia. ${ }^{6}$ Numa amostra aleatória do estrato de 0-50, calculada num nível de confiança de 95\%, 32\% eram parceiros. Contudo, $70 \%$ desta amostra envolveram estabelecimentos de menos de 10 ha, embora este estrato forme apenas $43 \%$ do setor de 0-50 ha, segundo o Censo Agrícola de 1975.

Tabela 36 - Produção de feijão segundo a área cultivada por estrato de propriedade do município de Irecê.

\begin{tabular}{c|c|c} 
Estrato & Número de produtores & Área (ha) \\
\hline Menos de 1 & - & - \\
\hline $1-2$ & 1 & 1,7 \\
\hline $2-5$ & 67 & 242,8 \\
\hline $5-10$ & 199 & $1.377,4$ \\
\hline $10-25$ & 503 & $6.229,0$ \\
\hline $25-50$ & 502 & $9.945,5$ \\
\hline $50-100$ & 403 & $12.460,5$ \\
\hline $100-200$ & 290 & $12.456,5$ \\
\hline $200-500$ & 183 & $13.357,9$ \\
\hline $500-1.000$ & 29 & $3.767,4$ \\
\hline $1.000-2.000$ & 6 & $1.231,9$ \\
\hline $2.000-5.000$ & 1 & 258,0 \\
\hline Total & 1.682 & $61.328,6$
\end{tabular}

Fonte: INCRA, cadastro de 1972

É provável, então, que esta pesquisa superestime grandemente a proporção dos parceiros no estrato de 0-50 como um todo.

${ }^{6}$ Pesquisa sobre associativismo entre os pequenos produtores rurais de Irecê, SEPLANTEC, CPE/GTEP, 1981.
Porém, mesmo se aceitarmos um número tão alto quanto $40 \%$ do estrato de 0-10 ha compreendendo parceiros, e calcularmos na base de 5 ha por estabelecimento, segundo o censo de 75 , cerca de 2.400 ha poderiam ter sido plantados por parceiros, o que representaria apenas 3\% da área total colhida em 1975. Podemos dizer então que, embora a parceria esteja provavelmente subestimada no Censo Agrícola, ela não representa uma forma significativa, e muito menos típica de cultivo da área no caso das propriedades maiores.

Devemos então concluir que, embora o município de Irecê tenha sido considerado, desde os anos 50, a mais importante região produtora de culturas alimentares comercialmente em pequena escala, o grosso da produção total tem tendido a tornar-se concentrado em fazendas médias a grandes, cujos proprietários são produtores diretos. As condições peculiares da região permitiram a completa mecanização das fases de preparo do solo e plantio, possibilitando a consolidação de fazendas médias a grandes que praticam culturas alimentares comercialmente. Além disso, o crédito subsidiado nos anos 70 veio privilegiar ainda mais as propriedades maiores no estrato de mais de 50 ha, particularmente aquelas entre 200 e 500 ha.

\section{Dados globais sobre a evolução do POLONORDESTE}

No entanto, apesar desta retração do setor de pequena produção, os dados globais do Programa POLONORDESTE, em contraste com o exemplo de Paraguaçu, atestam o caráter mais dinâmico do pequeno produtor em Irecê, e as vantagens da homogeneidade dos sistemas de produção que predominam na área. Este dinamismo maior, porém, como veremos adiante neste Capítulo, não implica necessariamente que o POLONORDESTE tenha tendido a reconsolidar este setor de pequenos produtores, revertendo o processo de marginalização analisado acima. Nos quatro anos, entre 1977 e 81 (ver Tabela 37), o número de produtores incorporados ao mecanismo de crédito orientado do programa cresceu de maneira estável, dando um enorme salto no último ano para o qual existem dados disponíveis. A área média cultivada também tendeu a crescer ${ }^{7}$ :

${ }^{7}$ Os dados globais referem-se aqui aos onze municípios do POLONORDESTE, e não apenas ao município de Irecê. Assim, eles provavelmente subestimam as tendências observadas. Em nossa análise detalhada do público do POLONORDESTE, mostrada em seções anteriores deste Capítulo, estaremos nos referindo especificamente a produtores do município de Irecê, 
Tabela 37 - POLONORDESTE: Irecê. Número de planos de crédito e área média cultivada - 1977/81.

\begin{tabular}{c|c|c} 
Ano agrícola & Número de planos & Área média \\
\hline $1977 / 78$ & 1.240 & 7,8 \\
\hline $1978 / 79$ & 2.172 & 7,3 \\
\hline $1979 / 80$ & 3.882 & 11,0 \\
\hline $1980 / 81$ & 9.023 & 10,6
\end{tabular}

Fonte: Unidade Técnica PoLONORDESTE, Irecê.

Não temos os dados sobre a representação proporcional dos diferentes estratos contidos na camada entre 0 e 50 ha, que define o público do programa, e então é possível que este aumento na área média cultivada represente a incorporação diferencial dos estratos maiores em anos subsequentes.

Contudo, a manutenção de uma área quase igual à do ano anterior em 1981, apesar do aumento do número de usuários de crédito em quase três vezes - aumento este que deve ter envolvido a incorporação de uma grande parte do estrato inferior - sugere uma tendência de aumento na área cultivada como efeito da incorporação ao crédito orientado oficial.

Tal hipótese é confirmada por uma investigação dos que usaram o crédito nos anos de 1977/78. Comparando-se o tamanho total das propriedades com a área cultivada nestes dois anos, observou-se que $60 \%$ dos que tinham possibilidade de expansão aumentaram sua área cultivada de um ano para o seguinte.

Estas cifras certamente subestimam a tendência de aumento da área cultivada, visto que o tamanho total da propriedade não é necessariamente igual à área total passível de cultivo. Realmente, $21 \%$ não foram capazes de aumentar sua área, e dos que o fizeram, 35\% não teriam condições de aumentar sua área no ano seguinte.

Examinaremos os limites estruturais impostos pelo tamanho das propriedades numa seção ulterior deste Capítulo. Está claro, porém, que em todos os três projetos examinados o aumento na área cultivada é uma tendência constante. Isto sugere que, quaisquer que tenham sido as

dado que: 1. o grosso do PDRI Irecê tem-se concentrado lá (em 79/80, 44\% dos que receberam crédito provinham deste único município); e 2 . o processo de modernização, e portanto suas implicações também, estão mais claramente desenvolvidos neste município. melhoras alcançadas em termos de produtividade por unidade cultivada, elas não foram suficientes para conter esta tendência de aumento absoluto na área plantada. Só no caso de Irecê temos evidências de um aumento considerável de produtividade, que, pelo menos em parte, pode ser correlacionado com a adoção de insumos modernos, no caso sementes melhoradas. ${ }^{8}$ Aparentemente, a imprevisibilidade das colheitas é em si mesma suficiente para eliminar uma confiança exclusiva na produtividade por unidade cultivada. Mesmo no caso da incorporação de insumos modernos, a tendência é de um aumento concomitante na área total cultivada.

Assim, o pressuposto da estratégia modernizadora - de que um aumento em produtividade pode compensar a exiguidade da área cultivada, tomando o minifúndio uma unidade produtiva viável, o que diminuiria a pressão pela reforma agrária - parece ser irrealista, na prática.

Os dados de Irecê também confirmam a correlação observada, particularmente no Capítulo anterior, entre envolvimento com o crédito de custeio oficial e a tendência para uma dependência paralela do crédito de investimento, que aumentou de $11 \%$ do total em 1978/79 para 40\% em 1980/81, matéria que examinaremos mais detalhadamente adiante, neste Capítulo.

\section{Resultados da pesquisa sobre o setor minifundiário de Irecê}

Antes de examinar com mais detalhe a dinâmica do POLONORDESTE em Irecê, consideraremos brevemente as conclusões de uma pesquisa realizada pelo Centro de Pesquisas e Estudos do Estado da Bahia entre os pequenos produtores do município de Irecê, para ver até que ponto esta pesquisa pode captar as características particulares do público do POLONORDESTE. ${ }^{9}$

O objetivo desta pesquisa era analisar as formas de associação existentes no estrato de pequenos produtores, não tendo portanto a intenção

\footnotetext{
${ }^{8}$ Aqui os cálculos se baseiam nos dados das agências bancárias locais sobre os usuários do crédito do POLONORDESTE.

${ }^{9} \mathrm{Em} 79$, a produtividade média de feijão em Irecê subiu a $672 \mathrm{~kg}$ por ha, contra 311 no ano anterior. Isto foi atribuído em parte à introdução de uma nova variedade de sementes rústicas e resistentes.
} 
de avaliar o POLONORDESTE, nem privilegiar o público deste Programa na sua amostragem.

Como observamos acima, esta amostra exagera o peso do grupo de 0 a 10 ha no município de Irecê, visto que este último corresponde a apenas $43 \%$ do estrato de $0-50$ ha, segundo o Censo de 1975, enquanto constitui $70 \%$ da amostra da pesquisa. Como resultado, embora em 79/80 61\% dos integrantes do estrato de 0-50 no município de Irecê fossem usuários do crédito do POLONORDESTE, apenas $19 \%$ na amostra da pesquisa recebiam crédito oficial. ${ }^{10}$

Vários indicadores confirmam a hipótese de que esta amostra reflete predominantemente as condições da camada inferior dos pequenos produtores. Apenas 32\% declararam-se proprietários, e a grande maioria compreendeu parceiros, arrendatários, simples trabalhadores rurais, ou plantadores de terra cedida temporariamente. ${ }^{11} 66 \%$ dos entrevistados, além de cultivar seus próprios lotes de terra, tinham outras ocupações (agrícolas, em $67 \%$ dos casos). ${ }^{12}$ Além disso, $77 \%$ tinham a renda familiar bruta (de todas as fontes) inferior a três salários mínimos. ${ }^{13}$

Porém, embora a maioria destes produtores tenham características de mão de obra de reserva, ${ }^{14}$ é a agricultura comercial, e não de subsistência, que predomina entre eles, e neste ponto eles podem fornecer indicações sobre as características do público do POLONORDESTE.

O sistema de produção dominante empregado é a plantação mista de feijão/milho/mamona, que, como vimos, é o sistema predominante na região toda para pequenos, médios e mesmo grandes fazendeiros. $72 \%$ dos que declararam colheitas no ano anterior empregaram este sistema, e, destes, $62 \%$ venderam mais de $70 \%$ de sua produção de feijão, $53 \%$ venderam mais de $70 \%$ de seu milho, enquanto naturalmente toda a

${ }^{10}$ Ver Pesquisas sobre associativismo entre os pequenos produtores rurais de Irecê, SEPLANTEC-CPE/GTEP, 1981 (mimeo).

${ }^{11}$ Vol. 2, p. 138.

${ }^{12}$ Op. cit., vol. 2, p. 45.

${ }_{13}^{13}$ Op. cit., vol. 2, p. 48A

${ }^{14}$ Op. cit., vol. 2, p. $51 \mathrm{~A}$ produção de mamona foi comercializada. Além disso, 55\% dos que usaram este sistema de produção plantaram mais de $90 \%$ da área total de sua terra. ${ }^{15}$

É esta série de fatos que explica porque, embora $70 \%$ dos entrevistados tivessem pelo menos um membro da família trabalhando em outras fazendas na safra anterior, muitos deles (57\%) contrataram mão de obra, deles próprios. ${ }^{16}$ Temos aqui um claro exemplo do caráter estrutural do trabalho não-familiar no contexto da produção comercial, em oposição à de simples subsistência.

Também é interessante observar que, embora várias formas de ajuda mútua fossem a resposta tradicional a esta carência de mão de obra no sistema de produção familiar, estas trocas de serviço entre iguais desempenham um papel mínimo no trabalho destas pequenas propriedades, que é esmagadoramente assalariado. ${ }^{17}$ Além disso, na questão relativa às características destes assalariados, 70\% responderam que eles eram agricultores sem-terra; e, dos que trabalhavam eles próprios em outras propriedades, $84 \%$ indicaram a necessidade econômica como a força motivadora para seu trabalho como assalariados. ${ }^{18}$

Estas conclusões confirmam a pesquisa do PEC/SR, indicando que o trabalho assalariado temporário na pequena produção não pode ser encarado como a expressão monetarizada de padrões tradicionais de ajuda mútua. ${ }^{19}$ Um exemplo deste fenômeno é fornecido por Leon Zamosc, em seu estudo da produção camponesa de sisal na Colômbia. ${ }^{20}$ Uma das principais características desta prática observada por Zamosc é a natureza simbólica

\footnotetext{
${ }^{15}$ Muitos (25\%) não declararam colheita. Embora uma parte desta cifra tenha-se devido a respostas erradas, a falta de acesso à terra foi citada como uma importante razão (ver Op. cit., vol. 2, p. 75).

${ }^{16}$ Op. cit., vol. 2 , p. 72 e p. 76

${ }^{17}$ Op. cit., vol. 2, p. 58 a 70 (dados sobre trabalho familiar e contratado).

${ }^{18}$ Op. cit., vol. 2, p. 64

${ }^{19}$ Op. cit., vol. 2, p. 61

${ }^{20}$ Cf. El fique y las empaques en Colombia, Leon Zamosc, Bogotá D.E., 1980 (mimeo), p. 190 e seguintes. Parece que as fortes tradições comunais e a produção unificada de uma cultura comercial e a produção unificada da ajuda mútua a uma economia monetarizada. Mas mesmo lá a prática se limita aos camponeses mais pobres, e unicamente no período de colheita, sendo o assalariamento temporário, como meio de complementar a renda, a prática dominante, mesmo neste setor
} 
do pagamento em dinheiro, que é bem inferior ao salário diário normal na região.

Como vimos no caso do PEC/SR, o salário médio era consideravelmente maior que o previsto nos cálculos do crédito oficial. Em Irecê, segundo o relatório da Unidade Técnica, ${ }^{21}$ os pequenos produtores tendem a pagar um salário-dia mais alto que os fazendeiros das propriedades maiores, possivelmente devido a dificuldades em garantir o recrutamento da mão de obra por períodos mais curtos. Este emprego de mão de obra assalariada também não se restringe a uma fase do ciclo agrícola. Enquanto a uma questão aberta $78 \%$ responderam citando a colheita como um dos períodos em que se contratava trabalho, apenas $34 \%$ disseram contratar mão de obra exclusivamente para a fase de colheita. $27 \%$ indicaram a estação de plantio junto com outros períodos, $25 \%$ indicaram preparo do solo, e $24 \%$ a fase de tratos culturais. ${ }^{22}$ Embora o período da safra seja claramente dominante, ele não é de modo algum o único em que se recorre a trabalho assalariado.

O número de trabalhadores contratados por estabelecimento também atesta a importância do trabalho não-familiar, como demonstra a Tabela 38.

Tabela 38 - Discriminação do trabalho temporário contratado por estabelecimento

\begin{tabular}{c|c|c}
$\begin{array}{c}\text { No. de trabalhadores } \\
\text { tempo }\end{array}$ & $\begin{array}{c}\text { agrícola. } \\
\mathrm{N}^{\mathbf{o}} \text {. de estabelecimentos }\end{array}$ & $\begin{array}{c}\% \text { do total de } \\
\text { estabelecimentos }\end{array}$ \\
\hline $1-2$ & 21 & 20,19 \\
\hline $2 / 3-5$ & 43 & 41,35 \\
\hline $6-10$ & 24 & 23,08 \\
\hline $11-20$ & 07 & 6,73 \\
\hline $21-30$ & 07 & 6,73 \\
\hline 31 ou + & 02 & 1,92
\end{tabular}

Fonte: Pesquisa da SEPLANTEC - CPE/GTEP, op. cit., vol. 2, p. 66.

Como se vê na tabela, cerca de $40 \%$ dos que contratam mão de obra empregaram mais de seis trabalhadores por estabelecimento, em momentos variados do ano agrícola anterior.

\footnotetext{
${ }^{21}$ Ver Histórico do PDRI Irecê, Unidade Técnica de Irecê, p. 6

${ }^{22}$ Pesquisa sobre associativismo, op. cit., vol. 2, p. 69.
}

Infelizmente, esta pesquisa não investiga a correlação entre os que contratam trabalho e os que trabalham eles próprios fora de seu estabelecimento. Também não determina a importância de variáveis tais como o tamanho do estabelecimento, o uso do crédito oficial, e a sua relação com a predominância da contratação de mão de obra ou da busca de emprego fora do estabelecimento. Apesar disso, por mostrar o peso da agricultura comercial, a importância e o caráter especificamente mercantil do trabalho contratado, numa amostra que privilegia os menores dentro do setor dos pequenos produtores, esta pesquisa nos fornece um importante ponto de referência para o exame do público do POLONORDESTE.

\section{Evidências obtidas na pesquisa de campo da EMATERBA}

Estes dados sobre a contratação de trabalho contrastam agudamente com os resultados publicados na pesquisa de campo realizada pelo serviço de Assistência Técnica, nos onze municípios que formam o público do POLONORDESTE, em julho de $1978 .^{23}$

Embora os entrevistados não tenham sido escolhidos com base em critérios de amostragem específicos, a pesquisa pode reivindicar representatividade com base em: a) seu tamanho: 2.341 entrevistas espalhadas por todos os onze municípios, compondo uma média de 10,8\% da população agrícola total; $b$ ) a inclusão prioritária de agricultores no estrato de 0-50 ha, que constituem $81 \%$ da amostra total.

Além disso, diferentemente da pesquisa anterior, o estrato de 0-10 ha representou apenas $41 \%$ do público entrevistado no setor de 0 a 50 . Embora para a região como um todo isto subestime ã participação do grupo entre 0 e 10, na mesma medida em que a pesquisa anterior a superestimava, representa um reflexo mais exato da distribuição da população no município de Irecê, que é o objeto específico de nossa análise.

De acordo com a tabela publicada acerca do caráter do trabalho agrícola, apenas 40,5\% dos estabelecimentos empregam trabalho nãofamiliar, conclusão que se repete no texto do relatório da pesquisa. ${ }^{24}$

${ }^{23}$ Cf. Levantamento da realidade agrícola da Região de Irecê, EMATERBA, Irecê, Bahia, 1980.

${ }^{24}$ Levantamento..., op. cit., p. 50 
Porém, cerca de $67 \%$ do total de entrevistados deram respostas indicando formas de pagamento empregadas para mão de obra não-familiar, o que levantou dúvidas acerca da confiabilidade dos dados. ${ }^{25}$

Felizmente, foi-nos dado acesso aos questionários desta pesquisa, e foi possível confirmar que esta baixa percentagem era resultado de um erro no processamento dos dados. ${ }^{26}$ Dos números que serviram como fonte, verifica-se que $67 \%$ dos entrevistados declararam-se usuários de mão de obra não-familiar, cifra compatível com a pesquisa anterior.

Embora os resultados não discriminem as respostas a esta questão segundo o estrato de área ou o emprego ou não do crédito, pudemos examinar os dados para o município de Irecê, isolando o estrato de $0-50 . \mathrm{Na}$ tabela que se segue, podemos ver confirmado este elevado e generalizado emprego do trabalho não-familiar. Mais importante ainda, porém, é a evidência de que os usuários do crédito tanto intensificam o emprego do trabalho não-familiar quanto diminuem agudamente a frequência com que empregam a si mesmos fora de sua propriedade. Estas conclusões confirmam os dados análogos discutidos no Capítulo sobre a região de Paraguaçu.

Tabela 39 - Proporções da contratação de trabalho e do emprego do trabalho familiar fora do estabelecimento discriminadas segundo o uso ou não do crédito.

\begin{tabular}{c|c|c|c|c}
\multirow{2}{*}{$\begin{array}{c}\text { Uso ou não do } \\
\text { crédito }\end{array}$} & \multicolumn{2}{|c|}{ Proporção dos que contratam } & \multicolumn{2}{|c}{$\begin{array}{c}\text { Proporção dos que trabalham } \\
\text { fora }\end{array}$} \\
\cline { 2 - 5 } & Sim & Não & Sim & Não \\
\hline Não-usuários & $43(60 \%)$ & $29(40 \%)$ & $39(55 \%)$ & $32(45 \%)$ \\
\hline Usuários & $173(84 \%)$ & $33(16 \%)$ & $74(35 \%)$ & $138(65 \%)$
\end{tabular}

Fonte: Cálculos a partir dos questionários da pesquisa Levantamento..., op. cit.

Nas razões apresentadas para o trabalho fora do próprio estabelecimento, fica claro que este trabalho não é encarado como um simples intercâmbio de serviços que agora assume uma forma monetária. De 1.089 entrevistados, 250 alegaram a exiguidade de suas propriedades;

\footnotetext{
${ }^{25}$ Levantamento..., op. cit., p. 54.

${ }^{26}$ Queremos enfatizar que esta pesquisa foi um ambicioso empreendimento, levado a cabo por iniciativa do pessoal da assistência técnica residente na área em acréscimo às suas atividades profissionais normais. Apesar deste erro isolado na elaboração dos resultados, a pesquisa como um todo é uma fonte extremamente valiosa para quem deseje estudar a dinâmica da região de Irecê em anos recentes.
}

532 apontaram para a necessidade de aumentar a renda e 200 indicaram a falta de crédito.

Estes dados confirmam tanto a nossa conclusão de que o crédito é o elemento decisivo a permitir a fixação do trabalho familiar (o crédito é também uma solução para a "necessidade de aumentar a renda"), quanto mostram os limites impostos a esta absorção pela estrutura agrária.

Os dados desta pesquisa também deixam claro que existe uma tendência dos que trabalham fora de seu próprio estabelecimento empregarem menos trabalho não-familiar que os que não trabalham fora, tendência esta comum tanto a usuários quanto a não-usuários de crédito. Para os usuários, $88 \%$ dos que não trabalham fora como assalariados empregam trabalho não-familiar, percentagem que cai para $67 \%$ no caso dos que trabalham fora. Entre os que não usam o crédito, $41 \%$ dos que trabalhavam fora também empregavam trabalho de fora, número que sobe para $78 \%$ no caso dos que não trabalhavam fora. ${ }^{27}$

Deste modo, as evidências sugerem fortemente que, embora um intercâmbio de trabalho seja comum de facto, ele não é encarado como uma prática normal, mas como um produto da necessidade econômica, e que a incorporação ao crédito oficial reduz drasticamente o recurso ao trabalho fora dos estabelecimentos, ao mesmo tempo em que aumenta significativamente a contratação de trabalho.

Os dados globais da pesquisa confirmam o caráter fortemente comercial do trabalho não-familiar, tendo 1.509 declarado pagamento em salário, 11 pagamentos em espécie, e apenas 54 indicando uma troca de serviços. ${ }^{28}$ Além disso, no município examinado (Irecê), no estrato de 0 a 50 só foram mencionados dois casos de ajuda mútua.

Tivemos a oportunidade de confirmar o peso desta mão de obra contratada em nosso próprio exame dos registros de clientes do POLONORDESTE elaborados pelas equipes da Assistência Técnica da EMATERBA. Em duas de suas seis agências, 88\% dos 398 registros

\footnotetext{
${ }^{27}$ Cálculos a partir dos questionários da pesquisa Levantamento... , Op. cit.

${ }^{28}$ Levantamento... , Op. cit.
} 
completos consultados de pessoas que trabalhavam com crédito indicaram emprego de mão de obra contratada. ${ }^{29}$

\section{Crédito de investimento e o público do Polonordeste}

Se a relação entre o crédito oficial e uma crescente dependência para com o trabalho assalariado é plenamente confirmada no caso de Irecê, não menos verdadeira é a relação entre o recurso ao crédito de custeio e a procura do crédito de investimento, cuja contribuição relativa no crédito total cedido aumentou de $11 \%$ para $24 \%$ e para $40 \%$ nos três anos para os quais dispomos de dados. Os dados de Irecê corroboram portanto os resultados do PEC/SR, e sublinham tendências apenas parcialmente visíveis no exemplo de Paraguaçu.

No caso da agência da EMATERBA de Irecê, pudemos examinar os registros dos clientes do POLONORDESTE empregados por cada equipe da assistência técnica durante a safra de 80/81. Como se pode ver na Tabela 40, de um total de 1.311 produtores, 653 , ou $50 \%$, também recorreram a crédito de investimento. Porém, se deixarmos de lado a equipe 4 , que é atípica, este número sobe para $62 \%$, uma média extremamente elevada, quando se reconhece que o crédito de investimento não é procurado todos os anos. ${ }^{30}$

Tabela 40 - Envolvimento do público do POLONORDESTE com crédito de investimento: Irecê.

\begin{tabular}{c|c|c}
$\begin{array}{c}\text { Equipes da } \\
\text { assistência técnica }\end{array}$ & $\begin{array}{c}\text { Público do POLONORDESTE } \\
\text { assistido }^{31}\end{array}$ & $\begin{array}{c}\text { Usuários do crédito de } \\
\text { investimento }\end{array}$ \\
\hline 1 & 298 & 122 \\
\hline 2 & 193 & 176 \\
\hline 3 & 261 & 118 \\
\hline 4 & 292 & 27 \\
\hline 5 & 271 & 210 \\
\hline Total & 1.1311 & 653 \\
\hline
\end{tabular}

Fonte: Cálculos a partir dos registros da Assistência Técnica, agência de Irecê.

\footnotetext{
${ }^{29}$ Dado recolhido durante a pesquisa de campo em julho de 1981 nas agências de Central e Presidente Dutra.

${ }^{30}$ Devem-se considerar também os limites impostos à cessão de crédito de investimento pelas agências bancárias, que tendem a limitar a demanda real.

31 Também inclui os assistidos que não usam crédito, o que deve significar que a percentagem do crédito de investimento sobre o de custeio é substancialmente maior.
}

Se desmembramos este crédito de acordo com os diversos itens financiados, podemos observar um quadro de certo modo semelhante ao do caso de PEC/SR, conforme se vê na Tabela 41.

Tabela 41 - Discriminação dos itens financiados pelo crédito de investimento de

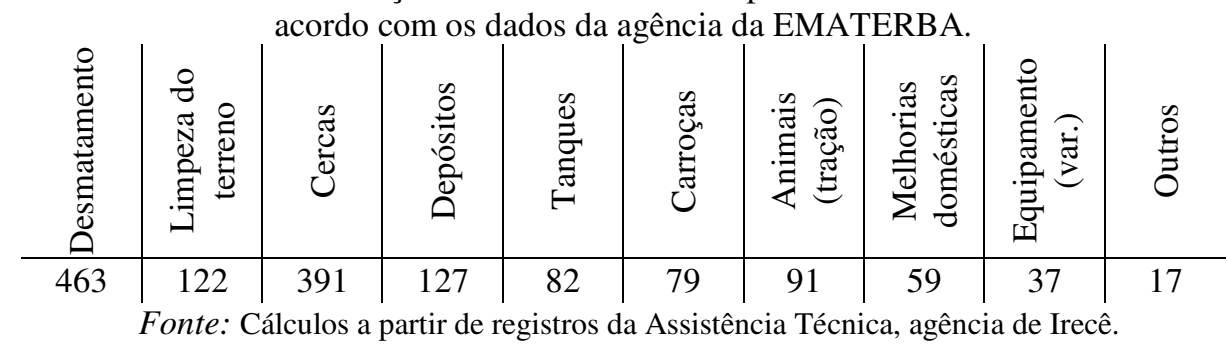

Assim, os maiores compromissos advindos da incorporação à produção subsidiada pelo crédito oficial levam a uma necessidade de melhoramentos básicos nas propriedades, e, no contexto da rápida valorização da terra, à necessidade de se estabelecerem de forma indiscutível os direitos sobre a propriedade inteira, especialmente face à tendência de aumento contínuo na área cultivada.

A Tabela 42, que discrimina a distribuição do crédito de investimento segundo o estrato de área em comparação com os dados para o público total incorporado ao POLONORDESTE, mostra que esta tendência é comum a todas as propriedades, sem modificar-se muito para as de menor estrato. Mas a renda agrícola e, portanto, a área passível de ser cultivada, determinam as somas do crédito de investimento cedidas, o que cria "economias de escala" dentro da camada de pequenos produtores.

Tabela 42 - Comparação da distribuição dos créditos de custeio e investimento entre os estratos de área.

\begin{tabular}{c|c|c|c|c} 
& \multicolumn{4}{|c}{ entre os estratos de área. } \\
Estratos de área & \multicolumn{2}{|c|}{ Crédito de custeio } & \multicolumn{2}{c}{ Crédito de investimento } \\
\hline $0-10$ & 344 & $26 \%$ & 121 & $20 \%$ \\
\hline $10-20$ & 266 & $20 \%$ & 179 & $30 \%$ \\
\hline $20-50$ & 580 & $44 \%$ & 248 & $41 \%$ \\
\hline $50+$ & 121 & $9 \%$ & 58 & $9 \%$ \\
\hline Total & 1.311 & $100 \%$ & 606 & $100 \%$
\end{tabular}

Fonte: Cálculos a partir de registros da Assistência Técnica, agência de Irecê 


\section{Caracterização do pequeno agricultor modernizado}

Assim, o caso de Irecê, devido às peculiaridades de sua estrutura agrária, evidencia da maneira mais aguda as tendências básicas que estavam parcialmente visíveis na região de Paraguaçu, e mais claramente expressas nas condições artificiais do PEC/SR.

Como consequência desta nova dinâmica criada pela incorporação às estruturas do crédito oficial, temos, em primeiro lugar, a transformação do minifundiário num agricultor em tempo integral, cuja renda portanto dependerá agora da produção de seu estabelecimento, ou, mais exatamente, do preço de mercado de seus produtos.

Ao mesmo tempo, o crédito oficial exige a absorção de insumos modernos como precondição para a produção. Embora este processo esteja em sua fase inicial, e enquanto, por exemplo, no caso das sementes melhoradas, a falta de suprimento, a má qualidade, e as condições climáticas desfavoráveis possam permitir que os agricultores continuem a usar suas próprias sementes sem serem identificados, é óbvio que na região de Irecê a adoção de sementes melhoradas está rapidamente ganhando terreno. Em 78/79, a Cooperativa de Irecê produziu 771 hectares do feijão melhorado - IPA 74-19. Em 80/81, esta área tinha aumentado para 5.999 ha. Além disso, um total de 1.200 toneladas de sementes melhoradas de feijão foram computadas nos planos de crédito do POLONORDESTE para 1980/81.

O emprego de defensivos é mais difícil de ser calculado, mas a precondição para se entrar no esquema do seguro de crédito é a apresentação das notas de compra dos insumos para os quais o crédito fora liberado. Embora isto também seja suscetível de sonegação, e a venda de notas falsas seja um florescente novo ramo de negócios, a tendência é de uma dependência crescente também do emprego de defensivos, de acordo com o Relatório da unidade técnica mencionado acima. ${ }^{32}$ Cerca de $867 \mathrm{t}$ de defensivos foram incluídas nos planos de crédito do POLONORDESTE para $1980 / 81 .^{33}$

\footnotetext{
${ }_{32}^{32}$ Histórico do PDRI, Irecê, Unidade Técnica de Irecê, p. 8.

${ }^{33}$ Op. cit.
}

Assim, a integração ao crédito oficial não vem simplesmente criar ou consolidar produtores simples de mercadorias, mas, especificamente, produtores que incorporam insumos modernos como precondição para o processo produtivo. Entre o trabalho do agricultor e sua terra, interpõem-se meios de produção adquiridos, cujos preços são determinados pelo setor agroindustrial. Deste modo, os diferentes capitais que compõem o setor agroindustrial combinam-se para impor, via mecanismo de preços, ritmos de produtividade que apenas tenderão, por sua vez, a uma crescente deterioração nos preços relativos. Além disso, embora em conjunturas favoráveis como as colheitas recentes de Irecê os preços dos produtos agrícolas possam subir mais que a inflação, tais preços têm tendido a crescer significativamente menos que os dos insumos agrícolas. De acordo com dados da CEPA-Ba, os preços de pesticidas e fertilizantes para o agricultor aumentaram em 571\% nos anos entre 1977 e 80, enquanto os preços médios pagos pelos três produtos que predominam na região de Irecê subiram em apenas $401 \%$ no mesmo período.

Podemos dizer então que o pequeno agricultor em processo de modernização não produz mais para a satisfação direta das necessidades de subsistência de sua família, nem de acordo com os preços de mercado de seus produtos em comparação com os preços de outros artigos de necessidade básica, como seria o caso da produção simples de mercadorias tradicional. Neste último caso, um rebaixamento nos padrões de vida poderia compensar os preços comerciais desfavoráveis ao produtor. $\mathrm{O}$ pequeno agricultor em processo de modernização tem agora de produzir em função dos novos custos de produção determinados pelo setor agroindustrial, que por sua vez são agora a precondição para o acesso ao crédito oficial.

Além disso, sua produção deve agora cobrir também o custo de pagamento do crédito de investimento, que se tomou, como vimos, uma parte integrante deste processo de modernização.

A tendência de aumento da área cultivada, portanto, não é simplesmente o produto da transformação do minifundiário num agricultor em tempo integral; ela é determinada pelos crescentes custos monetários de seus encargos econômicos. Por outro lado, o fato de que o agricultor não

\footnotetext{
${ }^{34}$ Cálculos do autor.
} 
conta mais com a renda obtida em trabalho fora de seu estabelecimento leva a uma dependência maior do crédito enquanto base da manutenção familiar. A área cultivada pelo agricultor em processo de modernização toma-se produto de um cálculo das necessidades de subsistência na base da renda líquida obtida na colheita mais o crédito, sendo os termos comerciais desfavoráveis (produtos agrícolas $\mathrm{x}$ insumos) e a dependência para com o crédito de investimento compensado, quando possível, por um aumento adicional da área cultivada. Mais adiante, neste Capítulo, analisaremos esta questão da nova economia de escala como produto da integração às estruturas do crédito oficial.

Uma consequência crucial deste processo é que não há mais qualquer relação imediata entre o suprimento de trabalho familiar e a definição de planos de produção. Como resultado, o trabalho assalariado toma-se uma parte estrutural do sistema de pequena produção familiar.

A característica básica geral de todo este processo, portanto, é a mercantilização sempre crescente de elementos do processo de trabalho, e é neste contexto que examinaremos a estratégia da assistência social do POLONORDESTE que intervém na região de Irecê.

\section{Mercantilização $x$ associativismo}

Como assinalamos em nossa discussão do exemplo de Paraguaçu, o motivo básico subjacente às tentativas de organizar o público do POLONORDESTE numa base coletiva é a necessidade de reduzir os custos de um programa planejado para envolver milhares de agricultores e suas famílias:

A abordagem associativista deriva portanto da necessidade de reconciliar o elevado número de agricultores carentes com as limitações econômicas do programa, permitindo assim uma melhor distribuição das oportunidades de assistência. ${ }^{35}$

No entanto, na região de Irecê, as tentativas de promover o associativismo ultrapassam o simples critério de eficiência, e são planejadas como uma precondição para o sucesso do programa. Em sua formulação mais geral, esta posição enfatiza a participação, e portanto a organização coletiva, como elementos-chave para a receptividade em relação aos

\footnotetext{
${ }^{35}$ Análise da ação social junto ao trabalho de produção em Irecê, EMATERBA, Bahia, 1980.
}

objetivos do programa. ${ }^{36}$ Mas dois argumentos mais específicos são apresentados para a promoção do cooperativismo ao nível da produção: o uso cooperativo do trabalho e do equipamento agrícola pode compensar a falta de recursos; e compras e vendas feitas coletivamente podem criar economias de escala e, com isso, condições de competitividade em relação aos médios e grandes agricultores na área.

Consequentemente, os assistentes sociais que formam parte da equipe de extensão rural promovem a organização de agricultores em grupos de produtores, e, no interior destes, procuram estimular o uso comunitário do trabalho e do equipamento (invocando as formas tradicionais de ajuda mútua), cessão gratuita de terra a agricultores não-proprietários, compras e vendas em comum, e; de um modo mais geral, a auto-organização como método de resolver problemas. ${ }^{37}$ Tivemos oportunidade de examinar os relatórios sobre os resultados do desenvolvimento destes grupos de produtores em quatro municípios. Tais relatórios, embora baseados em critérios muito subjetivos ${ }^{38}$ e tendo portanto um valor limitado, mostram resultados muito modestos, com exceção do emprego do trabalho comunitário no município de Canarana.

A maioria destes grupos (sem o município de Canarana, a esmagadora maioria) mostram pouca ou nenhuma resposta a estas tentativas de organização coletiva.

Apesar disso, os relatórios globais sobre a atividade da assistência social concluem:

${ }^{36}$ Este tema, beneficiando-se da "abertura" brasileira, mas refletindo uma tendência mais geral em relação aos programas de desenvolvimento rural, está fortemente presente na linha dos documentos da SUDENE-OEA (Organização dos Estados Americanos). Cf. Uma visão geral do funcionamento do Programa POLONORDESTE, Raul Fiorentini e John Redwood III, Recife, 1980; e especialmente Características e consequências do POLONORDESTE e análise preliminar das necessidades de capacitação dentro do Programa, dos mesmos autores, SUDENE-OEA, Recife, 1980.

37 Esta "auto-organização" significa essencialmente autoajuda, que também barateia os custos do Programa mobilizando o trabalho não pago do público do POLONORDESTE. Por outro lado, a auto-organização pode aumentar as reivindicações dirigidas ao POLONORDESTE pelo público visado. Deste modo a participação, ao expor os limites do programa, corre o risco de desmoralizá-lo. Isto já ocorreu em Irecê, e levou a uma certa cautela em relação a este tipo de assistência social.

${ }^{38}$ A imprecisão dos critérios e o fato de que estes relatórios refletem o desempenho dos técnicos provavelmente também levam a interpretações muito generosas dos resultados. 
Evidencia-se assim que os valores sociais do associativismo, solidariedade e cooperativismo são adotados por uma grande parte dos agricultores assistidos (Op. cit., p. 20).

Porém, se examinamos os dados apresentados neste documento referentes a Realizações de Grupos nos três anos 1977/80, mencionam-se apenas 70 grupos de produtores que teriam empregado formas de ajuda mútua durante o ciclo agrícola, o que representa somente $22 \%$ dos 320 grupos organizados na região neste período. ${ }^{39}$ Além disso, é significativo que o município de Irecê esteja ausente da lista de localidades que praticariam ajuda mútua.

Afirma-se que 36 grupos (12\%) estiveram envolvidos com vendas conjuntas de produtos agrícolas (embora no corpo do texto o número fornecido seja de 5\%). E não há menção a compras ou uso conjunto de equipamento agrícola.

Portanto, apesar de uma contínua tentativa de se manterem ou ressuscitarem práticas coletivas tradicionais, apoiada na plena autoridade dos serviços de extensão rural, a mercantilização das relações sociais consequentes à massiva incorporação ao crédito subsidiado é aparentemente irreversível.

As raízes deste processo estão na própria natureza do crédito oficial, que inclui componentes para a contratação de mão de obra e o aluguel ou compra de equipamentos agrícolas. A mão de obra, cujo preço é geralmente fixado acima da média oficial, dificilmente optará pela troca de serviços, que é gratuita e cada vez mais imprevisível. De modo análogo, o equipamento pode ser alugado, ou, caso seja adquirido, precisa ser amortizado. Ambos estes fatores inibem seu uso coletivo.

O erro da abordagem da assistência social está na suposição de que existe uma escassez de recursos. A pronta disponibilidade do crédito subsidiado solapou na prática as precondições e costumes do trabalho coletivo. f: provável que os casos de ajuda mútua registrados ocorram em proporção inversa ao envolvimento com as estruturas do crédito oficial, e afetem especialmente os que recebem assistência técnica mas não o crédito. A este respeito, é significativo que o município de Canarana, depois de

\footnotetext{
${ }^{39}$ Cf. Análise da ação social..., op. cit., p. 10.
}

Xique-Xique, tivesse a maior proporção de não-usuários de crédito do público do POLONORDESTE.

O crédito oficial estimula portanto uma crescente mercantilização dos vários elementos do processo de trabalho, especialmente a mão de obra, sob a forma de contratos temporários.

\section{Modernização, mecanização e tecnologia alternativa}

Como observamos acima, existe uma tendência de aumento na produção, produto de custos monetários crescentes, que por sua vez são produto das exigências do crédito oficial, e dos termos comerciais desfavoráveis aos produtos agrícolas. Em conjunturas favoráveis de mercado (ou, mais exatamente, na expectativa de preços favoráveis), a área cultivada também tende a aumentar, o que é possibilitado pela componente do crédito para contratação de trabalho, que estabelece uma relativa autonomia entre a área produzida e a disponibilidade de trabalho familiar.

No Capítulo anterior, examinamos os limites impostos a este processo e a predominância continuada do trabalho familiar. Observamos também uma tendência (ou desejo) de mecanização, como tentativa de restabelecer o controle do trabalho familiar sobre a produção e eliminar a dependência para com a mão de obra assalariada.

No caso de Irecê, porém, os itens do crédito de investimento aparentemente não indicam qualquer tendência em direção à mecanização. Embora uma significativa proporção de animais de tração (91) tenha sido comprada, há uma ausência quase absoluta de arados e grades (uma unidade cada), o que sugere, especialmente face ao grande número de carroças compradas (79), que estes animais fossem antes de tudo para transporte.

Contudo, relatórios preparados pela Comissão Agrícola do Estado, ${ }^{40}$ e confirmados pela observação da região, mostram que o preparo de solo e o pré-plantio estão completamente mecanizados entre os pequenos produtores do POLONORDESTE. Tal prática contrasta agudamente com o conceito de "tecnologia apropriada" para o pequeno agricultor promovido pelo Banco Mundial, e incorporado às Diretrizes do Programa

${ }^{40} \mathrm{Cf}$. Informe mensal de acompanhamento conjuntural, CEPA-Ba, 1981 
POLONORDESTE. ${ }^{41}$ Neste contexto, define-se a tecnologia apropriada como a que visa a um emprego máximo do trabalho manual e de um nível de tecnologia que permita suprir as demandas do processo produtivo dentro dos limites do trabalho familiar. ${ }^{42}$

As diretrizes do POLONORDESTE de 1981/82 em relação à mecanização são categóricas a este respeito:

$$
\begin{aligned}
& \text { 2.2.3. Mecanização: } \\
& \text { a) Excluir a formação de unidades móveis de tratores; } \\
& \text { b) Promover a tração animal. } \\
& \text { (Diretrizes gerais para programação, 1981/82) }
\end{aligned}
$$

No entanto, apesar de uma forte campanha local em favor da tração animal, pode-se dizer que a mecanização é universal na fase de pré-plantio. No caso do PEC/SR, também observamos uma preferência marcante pela tração mecânica ao invés da animal.

O conceito de tecnologia apropriada deriva da suposição de que a mão de obra deve ser fixada no setor agrícola, e deduz as propostas tecnológicas de simples cálculos da disponibilidade de mão de obra familiar.

Uma série de fatores, porém, sugere que tal procedimento é ineficaz, porque representa uma abstração artificial da forma de inserção específica do setor da pequena produção agrícola na macroestrutura socioeconômica.

Ao nível técnico do processo produtivo, o problema-chave do agricultor não é saber se pode preparar todo o terreno que planejou com base na tração animal, economizando assim equipamento e trabalho

\footnotetext{
${ }^{41}$ Cf. Développement rural et technologie alternatives dans la stratégie de la Banque Mondiale, Jean-Jaques Dravon, esp. p. 9 e seguintes, Groupe d'Etude des Relations Economiques Intemationales (GEREI), Paris, 76. Para declaração oficial desta orientação pelo Banco, ver Desarrollo rural: documento de política setorial, Washington, 1975.

${ }^{42}$ Cf. Serviços de mecanização e a oferta de insumos (Doc. $\mathrm{n}^{\circ}$ 7, PDRI Paraguaçu), onde, apesar de reconhecer a necessidade de uma mecanização limitada, a equipe do Banco Mundial insiste em que, "de acordo com o projeto, a produção agrícola continuará a ser trabalho-intensivo e baseado na oferta de trabalho familiar". A mecanização limitar-se-ia a tarefas não repetitivas, como limpeza de terrenos.
}

contratado. $\mathrm{O}$ fator decisivo é a necessidade de realizar o serviço no menor tempo possível.

No caso de Irecê, isto significa preparar o terreno o mais proximamente possível da fase de plantio determinada pelas chuvas esparsas, de modo a evitar a germinação de ervas daninhas, que prejudicam a produtividade.

O recurso à mecanização independe de cálculos abstratos de custos relativos em comparação com a tração animal ou com as vantagens do trabalho familiar.

Pode ser também que a tração animal, envolvendo a compra de grades e arados e a manutenção de um cavalo ou boi o ano inteiro (os jegues, embora úteis para o transporte, não são usados na aração), tenha um custo global mais elevado, e, o que é mais importante, exija a conversão de terras potencialmente cultiváveis em pastos.

A concepção de uma necessidade de estimular a tecnologia trabalhointensiva também tende a superestimar o lado da oferta do trabalho familiar. Como já vimos, particularmente no caso do PEC/SR, a quantidade média de mão de obra familiar disponível reduz-se basicamente a marido, esposa mais um jovem adulto.

A tarefa de arar a terra empregando tração animal exige especialização, e caberia naturalmente ao chefe da família. Mas, durante este período, o agricultor está cada vez mais envolvido em atividades fora do estabelecimento negociando o crédito, o que normalmente requer várias visitas às agências bancárias e de assistência técnica locais; comprando sementes e outros insumos para o ano agrícola que começa etc. Então, a mecanização poupadora de mão de obra facilitaria estas atividades fora do estabelecimento, multiplicadas pelo próprio processo de modernização.

A estes dois aspectos somam-se as características do crédito, que vão obstar diretamente a tentativa de impor condições técnicas diferentes ao pequeno agricultor, pois os custos da produção são calculados na base do emprego de mecanização. Assim, o crédito oficial contém uma componente para o aluguel de aração mecanizado.

$\mathrm{Na}$ realidade, os pressupostos do crédito oficial prejudicam diretamente qualquer tentativa de consolidar uma tecnologia apropriada. $\mathrm{O}$ 
cálculo dos Valores Básicos do Crédito de Custeio, que se aplicam uniformemente para todo o Brasil (com certas adaptações para o Norte e Nordeste, para compensar variações nas estruturas de preços), estabelece uma correlação entre produtividade e o emprego de insumos modernos. A maior produtividade é calculada em dependência do uso das maiores quantidades de insumos modernos, e o empréstimo cedido e correspondentemente maior:

De acordo com os critérios estabelecidos na época de sua implantação, durante a safra 1979/80, os Valores Básicos de Crédito de Custeio variam segundo a produtividade de cada beneficiário. Assim, as culturas mais produtivas, que demandam maior dispêndio de fundos devido ao emprego de uma melhor tecnologia, receberão um Valor Básico de Crédito de Custeio mais elevado. ${ }^{43}$

Embora isto não corresponda necessariamente à realidade (a fertilidade natural do solo e as condições climáticas favoráveis podem desempenhar um papel mais importante), a tendência de tal política é favorecer as regiões e fazendas onde os índices de produtividade e a incorporação de insumos modernos convergem mais.

O crédito oficial tende portanto ao estabelecimento de uma taxa de produtividade média que penaliza os que não a atingem. Além disso, esta produtividade corresponde à geração de uma "mais-valia relativa", pois está baseada na promoção da máxima produtividade por unidade de trabalho despendida, e não, como no caso da tecnologia apropriada, na máxima quantidade de trabalho absoluto despendido.

Assim, o crédito oficial subordina a produção agrícola aos níveis técnicos alcançados pelos capitais agroindustriais, e estimula a produção agrícola na medida em que a sua produtividade não mais dependa dos caprichos da natureza, mas derive da subordinação do processo de trabalho aos meios de produção capitalista.

Deste modo, o conceito de tecnologia apropriada, da mesma forma que as tentativas já analisadas de promover formas não-mercantilizadas de relações sociais, não levam em conta a estrutura socioeconômica, que

\footnotetext{
${ }^{43}$ Comissão de Financiamento da Produção. Circular para julho de 1981
}

estabelece as condições de sobrevivência da pequena produção agrícola nos termos da tecnologia gerada pelo setor agroindustrial. ${ }^{44}$

\section{Contradições básicas do processo de modernização}

As contradições básicas envolvidas na modernização da agricultura familiar tradicional emergem mais claramente agora.

Vimos como as demandas extras advindas da incorporação ao crédito oficial tendem ao estabelecimento de padrões produtivos que ultrapassam a oferta de trabalho familiar da agricultura tradicional. A componentetrabalho do crédito resolve esta contradição permitindo a incorporação de trabalho contratado. Mas o elevado custo deste trabalho (em ambas as áreas examinadas, os salários eram significativamente mais altos que a componente-trabalho do crédito), e a incerteza de sua oferta, e o contraste de sua baixa produtividade com a do trabalho familiar, levam a que o agricultor se esforce por substituir a mão de obra contratada pela mecanização, visando a restaurar o controle do processo produtivo pela família. Esta tendência é estimulada pelas características específicas do crédito, que, como vimos, promove a absorção de insumos modernos.

Assim, a dinâmica desencadeada por esta incorporação ao crédito oficial, apesar dos esforços de se promover uma tecnologia apropriada, tende a provocar uma dependência estrutural da mecanização, ativamente estimulada pela componente do crédito destinada a este fim; contudo, o agricultor não tem condições de se apropriar destes novos meios de produção. Então a mecanização, apesar de liberar o agricultor da dependência para com o trabalho contratado, pelo menos em algumas fases do ciclo agrícola, não restaura o controle do trabalho familiar sobre o processo produtivo, mas lança o lavrador numa dependência ainda maior de tratores e equipamentos mecânicos, que são, em sua esmagadora maioria, propriedade de médios e grandes fazendeiros da região.

Em toda a região de Irecê, não há um caso sequer de um pequeno produtor recebendo crédito para a compra de um trator. Não se deve

\footnotetext{
${ }^{44}$ Embora isso seja mais difícil de calcular com precisão, o processo de modernização, que tem como uma de suas consequências a adoção de padrões "urbanos" de consumo (visível em Irecê, de modo típico, no florescimento do comércio de carros de segunda mão), aparentemente tenderia também a ocasionar uma desvalorização do trabalho manual em si mesmo, e predispor os agricultores a eliminar este seu trabalho via mecanização.
} 
procurar a explicação disso nos termos de uma aliança entre os gerentes bancários locais e os médios e grandes fazendeiros, ansiosos por compensar a subutilização de suas máquinas com lucrativos arranjos de aluguel embora seja isto o que ocorre na prática. ${ }^{45} \mathrm{O}$ que impede o recebimento de crédito pelo pequeno produtor para a compra de um trator é simplesmente a insuficiência de sua renda potencial para garantir sua capacidade de pagar o empréstimo nos limites tradicionais de tempo.

O Banco do Brasil, que é responsável por cerca de $80 \%$ dos empréstimos, baseia na verdade a sua cessão para a compra de tratores na exigência de uma área mínima de 60 hectares, bem superior à das maiores propriedades do público do POLONORDESTE. Os esforços para promover a compra de tratores em grupo têm sido infrutíferos, até agora, devido tanto à resistência dos bancos a esta forma de negócio, quanto à incerteza do pequeno agricultor quanto aos riscos desta responsabilidade partilhada. Os membros de um "grupo de produção", após haverem formalmente decidido pela adoção da compra conjunta, procuraram individualmente o técnico da extensão rural e deixaram claro que o que realmente queriam era possuir um trator pessoalmente.

Aqui, também a atração do mercado de aluguel de tratores parece ser maior que o apelo ao uso coletivo sem fins de lucro, que pode acabar sendo mais dispendioso que o aluguel individual.

Podemos dizer então que o processo de modernização estabelece continuamente novos limites mínimos de tecnologia para a produção, que divorciam cada vez mais o pequeno agricultor de uma relação direta com seus meios básicos de produção - o trabalho familiar e a terra. O início do processo produtivo, e todas as suas fases subsequentes, agora devem ser necessariamente mediados por meios de produção adquiridos - sementes, pesticidas, trabalho contratado e maquinaria.

Com a incorporação dos tratores, atinge-se um novo estágio, ao qual o pequeno agricultor tem acesso radicalmente desigual em comparação com os médios e grandes fazendeiros seus vizinhos.

${ }^{45}$ Cf. o excelente estudo dos pequenos produtores de açúcar feito por Delma Pessanha Neves: Lavradores e pequenos produtores de cana, Zahar, 81, onde arranjos de aluguel semelhantes tendem a ser interpretados essencialmente como o mecanismo que permite se atinjam os novos níveis de tecnificação exigidos, sem que se explorem as contradições envolvidas nesses arranjos.
Isto ocorre porque, embora em certas fases do ciclo agrícola (por exemplo, aração e preparo da terra) haja uma flexibilidade de tempo suficiente para permitir o funcionamento de um sistema de aluguel, ${ }^{46}$ isto não se dá em outras fases, estabelecendo-se assim uma grande vantagem para aqueles cujas fazendas têm tamanho suficiente para permitir a incorporação destes novos meios de produção.

Se tomarmos como exemplo a fase de plantio, este fator emerge com toda a clareza. A velocidade com que esta operação tem de ser levada a cabo, dado que a germinação ótima é determinada pelo regime das chuvas escassas da região, torna o aluguel de tratores inviável neste período.

Uma propriedade pequena requereria três pessoas trabalhando por três semanas para plantar 20 hectares manualmente. O plantio mecânico desta mesma área levaria apenas quatro dias. Logo, uma fazenda mecanizada poderia ter 100 ha cultivados nas mesmas três semanas, ${ }^{47}$ empregando o trabalho de uma só pessoa. Deste modo o pequeno produtor, dada a escassez das chuvas e a necessidade de plantar quando o solo está suficientemente úmido para permitir a germinação, não só tem sua área limitada pela falta de acesso à mecanização, como também é ameaçado com uma menor produtividade, devido à sua maior dificuldade para completar o processo de plantio durante o período ótimo de umidade do solo.

Além disso, a especialização exigida na fase do plantio, consequente à adoção das técnicas de espaçamento e profundidade do cultivo trazidas pela extensão rural, torna arriscado o recurso à contratação de trabalho, aumentando a desvantagem do pequeno agricultor. As formas tradicionais de ajuda mútua são por vezes empregadas como meio de superar este impasse, mas tal opção está sendo rapidamente inviabilizada pela crescente mercantilização das relações de trabalho.

A situação crítica do pequeno produtor em processo de modernização fica plenamente visível neste exemplo da fase de plantio, e ainda mais clara quando consideramos a evolução do trabalho familiar.

\footnotetext{
${ }^{46}$ Mesmo assim, há uma onda de pânico a cada ano na fase de pré-plantio, e muitos pequenos agricultores têm sua produção ameaçada por atrasos e dificuldades para alugar maquinaria.

${ }_{47}$ Dados extraídos de Sistemas de produção para feijão/milho/mamona, Irecê, Bahia, EMATERBA, 1980.
} 
Como já assinalamos, há relativa escassez de mão de obra familiar tanto no caso do PEC/SR quanto em Irecê. Além disso, o êxodo massivo de adultos jovens é uma ocorrência comum a todas as áreas rurais do Nordeste, ${ }^{48}$ e parece que as áreas do POLONORDESTE não são exceção, como os dados da região de Paraguaçu indicam embora não haja dados específicos disponíveis a este respeito com relação a Irecê.

Tal êxodo não pode ser diretamente explicado em termos das atrações monetárias dos salários urbanos. Se tomarmos um lavrador típico do POLONORDESTE no município de Irecê que cultive 15 hectares, podemos calcular sua renda líquida como se segue:

\begin{tabular}{|c|c|c|c|c|c|}
\hline \multirow{2}{*}{\multicolumn{2}{|c|}{$\begin{array}{l}\text { Produtividade } \\
\text { por ha em sacas }\end{array}$}} & $\begin{array}{l}\text { Renda típica de ur } \\
\text { Preços mínimos } \\
\text { por saca }\end{array}$ & Renda bruta & $\begin{array}{l}\text { ultive } 15 \text { ha } \\
\text { Pagamento } \\
\text { do crédito }\end{array}$ & $\begin{array}{l}\text { Renda } \\
\text { líquida }\end{array}$ \\
\hline & & $\mathrm{Cr} \$$ & $\mathrm{Cr} \$$ & $\mathrm{Cr} \$$ & $\mathrm{Cr} \$$ \\
\hline Feijão & 11 & $3.150,00$ & $705.485,00$ & $430.100,00$ & $275.385,00$ \\
\hline Milho & 15 & 735,00 & - & - & - \\
\hline Mamon & 13 & $1.420,00$ & - & - & - \\
\hline
\end{tabular}

Calculando o salário mínimo básico igual a Cr\$ 10.000 por mês, a renda líquida seria equivalente a 2,3 salários mínimos por unidade familiar por mês. Se somarmos a isto os créditos levantados, veremos que a renda do estabelecimento, em anos favoráveis, é de sobra suficiente para prover um salário mínimo per capita. ${ }^{50}$

\footnotetext{
${ }^{48}$ Sobre a região de Paraguaçu, cf. Pequenos produtores rurais na bacia de Paraguaçu, op. cit., onde a ausência de adultos jovens é encarada como típica dos pequenos estabelecimentos agrícolas. Cf. também o estudo da CPE/BAHIA na mesma região, citado no Capítulo Quarto.

${ }^{49}$ Produtividade baseada nos dados da EMATERBA para a safra de 1979/80.

${ }^{50}$ Em seu artigo "A tecnificação dos pequenos produtores em São Paulo" (mimeo, sem data), Juarez Brandão Lopes afirma que a modernização tende "inexoravelmente" a uma equalização na remuneração salarial dos setores capitalistas e de pequena produção agrícola. Com isto, ele muda a posição que, defendera em seu artigo do CEBRAP sobre o mesmo tema intitulado "Empresas e pequenos produtores no desenvolvimento do capitalismo agrário em São Paulo", onde explica a competitividade do pequeno produtor em termos de superexploração e subconsumo. Porém, embora aceite a tendência do desenvolvimento de um salário-mínimo per capita no setor da pequena produção em processo de modernização, ele não explica por que o pequeno produtor não opta pelo emprego assalariado no setor capitalista, exceto nos termos puramente subjetivos da relação do pequeno agricultor com a terra. Porém, se reconhecermos que o trabalho familiar não é remunerado, e que toda a renda
}

Contudo, a característica típica do trabalho familiar é ser nãoremunerado. Além disso, a renda líquida surge na forma de ganhos obtidos com a venda das colheitas, e é apropriada pelo chefe da família.

Nossa hipótese, então, é de que as características específicas do trabalho familiar não permitem a transformação da renda líquida numa forma de salário regular para o adulto jovem. Uma tal transformação do trabalho familiar não-remunerado de modo a comportar uma remuneração regular em salário seria o equivalente à contratação de um trabalhador permanente.

Assim, ao chegar à idade adulta, o jovem trabalhador, ao invés de ser transformado no equivalente a um trabalhador assalariado permanente, é substituído por um trabalhador temporário, fenômeno paralelo à substituição dos trabalhadores permanentes pelos temporários nas plantations, quando aqueles começaram a se transformar numa mão de obra predominantemente assalariada. Deste modo, o êxodo dos adultos jovens reflete na prática uma forma de resistência passiva à apropriação contínua de seu trabalho não-remunerado. Frente a isso, o chefe da família começa por intensificar o emprego do trabalho infantil combinado com o trabalho contratado temporário, e depois, na medida do possível, substitui a ambos pela mecanização.

A mecanização, por sua vez, representa não só uma redução da dependência para com o trabalho contratado, mas também uma substituição do trabalho familiar. Mais que isso: ao individualizar o processo de trabalho, o chefe de família com seu trator elimina o caráter coletivo do processo de produção, destruindo a lógica do trabalho agrícola familiar tradicional.

Embora as contradições específicas que envolvem o pequeno agricultor do Nordeste se expressem em sua incapacidade de completar o processo de modernização apropriando-se dos elementos da nova tecnologia mínima exigida, é importante ressaltar que a mecanização, longe de restaurar a autonomia da unidade agrícola familiar, cria um novo processo de trabalho individualizado que rompe a unidade familiar

líquida (i.é, uma média de três salários-mínimos) fica nas mãos do chefe de família, poderemos explicar mais claramente a persistência do pequeno produtor, e, como expomos no texto, o êxodo dos jovens adultos. 
tradicional, transformando os membros antes complementares de uma família em simples consumidores de trabalho não-familiar. ${ }^{51}$

\section{Conclusão}

O exemplo de Irecê permite-nos assim apreender as contradições estruturais da estratégia de modernização. Como vimos anteriormente, a produtividade aumentada não compensa de modo algum a exiguidade das áreas cultiváveis; logo, não pode tornar viáveis as propriedades muito pequenas. As maiores dentre as pequenas propriedades respondem à estratégia de modernização com uma dependência crescente de meios de produção adquiridos, cujo custo desfavorável em relação aos preços dos produtos agrícolas força uma contínua expansão na área cultivada.

Este processo aumenta a dependência estrutural para com o trabalho contratado, que também é estimulada pela componente contratação de mão de obra incluída no crédito subsidiado. Tal componente permite que a produção seja definida em termos relativamente independentes das reservas de trabalho familiar.

No entanto, a eficiência do trabalho manual decresce em proporção ao aumento da área cultivada. Os esforços para resolver este problema via formas de tecnologia alternativa são anulados pela inserção dos pequenos produtores na estrutura socioeconômica dominante, e pelas características do crédito oficial, que promove a tecnificação de acordo com as determinações da agroindústria.

Contudo, a plena mecanização é impedida pelos baixos níveis da renda agrícola que pode ser gerada em áreas cultiváveis restritas. Então, o agricultor semimodernizado, incapaz de completar a mecanização de seu processo produtivo, só pode incorporar novas áreas na base de uma eficiência decrescente.

Em consequência, ele se torna cada vez mais vulnerável às pressões exercidas pelos médios e grandes fazendeiros sobre os preços de aluguel do equipamento agrícola, num contexto de rápida valorização da terra que vai se acelerar ainda mais com o avanço da mecanização a outras fases do ciclo

${ }^{51}$ Dada a falta de um mercado de trabalho desenvolvido no meio rural, isto só pode levar a
uma aceleração do êxodo rural, o que frustra um dos objetivos centrais da estratégia do uma aceleração do êxodo rural, o que frustra um dos obj
POLONORDESTE - a fixação da mão de obra no campo. agrícola (particularmente a colheita, para a qual já estão sendo experimentadas novas máquinas combinadas).

Este grande aumento nos preços da terra durante os anos 70 foi produto das oportunidades para a agricultura em média e grande escala subsidiada pelos canais normais do crédito oficial, e não uma consequência direta do programa POLONORDESTE.

Os elevados preços da terra - Cr $\$ 100.000$ por hectare, cerca de $40 \%$ da renda líquida potencial de uma propriedade de 10 ha na região - não permitem ao pequeno produtor expandir sua produção, impossibilitando-o assim de mecanizar o processo de trabalho.

O maior beneficiário da modernização em Irecê continua sendo portanto o médio/grande fazendeiro. Na safra de 1980/81, cerca de 50\% da área cultivada continuaram a pertencer a propriedades de mais de 50 ha, apesar do aumento sem precedentes no número dos usuários do crédito do POLONORDESTE, e dos cinco anos de intervenção do Programa na área.

Embora o padrão dos acontecimentos futuros em Irecê não esteja claro, particularmente face às secas periódicas que tomam a agricultura subsidiada extremamente dispendiosa, ${ }^{52}$ a estratégia modernizadora criou novas contradições para o setor da pequena produção agrícola, e, ao interpor meios de produção capitalista entre o produtor direto e sua terra, destruiu o caráter tradicionalmente familiar do processo de trabalho.

$\mathrm{O}$ resultado é uma grande instabilidade para o setor produtivo. A subordinação aos ritmos de produção determinados pelo setor agroindustrial, ao invés de criar novas bases de reprodução para o setor da pequena produção agrícola tradicional do Nordeste, ameaça-o com a

\footnotetext{
${ }^{52}$ A Extensão Rural vem ultimamente promovendo culturas mais resistentes a seca na área, e a CODEVASF está elaborando um grande projeto de irrigação, abrangendo cerca de 400.000 ha que pode muito bem transformar o caráter da agricultura na região pela promoção do cultivo da cana-de-açúcar irrigada para o PROÁLCOOL, às expensas das culturas alimentares básicas.
} 
dissolução em favor de fazendas médias e grandes, onde os proprietários operam a maquinaria moderna. ${ }^{53}$

Parece haver então poucas perspectivas para um processo orgânico de modernização no contexto da pequena produção agrícola nordestina.
${ }^{53}$ Embora se costume identificar este setor como sendo o da agricultura capitalista, estes fazendeiros são essencialmente proprietários que participam diretamente do processo produtivo operando máquinas, e empregando apenas trabalho temporário, de um modo semelhante ao dos "pequenos" agricultores. A caracterização deste setor necessita ser feita urgentemente. Ao invés de "fazendeiros capitalistas" eles podem representar a variante nordestina da agricultura familiar modernizada.

\section{Conclusão}

\section{Síntese dos argumentos}

Na primeira parte de nosso estudo, mostramos como uma concepção fundamentalmente falsa do "pequeno produtor", gerada pelos órgãos executivos dos programas atuais de modernização (tanto brasileiros quanto ao nível do Banco Mundial) e baseada na premissa da autossuficiência da unidade de trabalho familiar, esvaziou de antemão as condições para uma análise da dinâmica da estratégia modernizadora para o setor da pequena produção agrícola.

Assinalamos também que o debate acadêmico no contexto brasileiro, embora indique empiricamente a presença do trabalho não-familiar no interior do processo de produção da pequena exploração agrícola, evita sistematicamente considerar a nível teórico o seu papel, conformando-se assim à definição oficial do produtor agrícola familiar autossuficiente.

Este hiato teórico foi atribuído à polarização em tomo do tema do trabalho contratado no debate clássico definido pelas contribuições de Lênin e Chayanov, as quais constituem ainda o referencial básico da análise contemporânea quer de forma direta, no caso de Lênin, quer através da obra de Amin/Vergopoulos, no caso de Chayanov. ${ }^{1}$

A análise do processo de trabalho da pequena produção agrícola foi paralisada pela suposição comum, estabelecida no debate clássico, de que a presença do trabalho assalariado era um fenômeno essencialmente de transição, produzindo uma dinâmica para a consolidação da agricultura capitalista.

No nosso reexame do debate, tentamos mostrar como esta concepção dogmática do significado do trabalho assalariado levou a uma interpretação errônea da evidência empírica, seja identificando exageradamente o emprego de tal trabalho com o processo de "kulakização" das explorações maiores, no caso de Lênin, seja subestimando seriamente a presença do trabalho assalariado, no caso de Chayanov.

\footnotetext{
${ }^{1}$ Ver A questão camponesa e o capitalismo, S. Amin e Kostas Vergopoulos.
} 
No Capítulo três da Primeira Parte realizamos os dados secundários relativos ao setor da pequena produção agrícola brasileira, em particular para o Nordeste, expondo as duas falhas básicas do conceito de "pequeno produtor" empregado no contexto dos programas de modernização.

Em primeiro lugar, mostramos como o latifúndio obstou a formação de um setor de pequenos produtores, favorecendo a consolidação de uma reserva de força de trabalho essencialmente multiforme. Em segundo lugar, indicamos como a dominância da estrutura latifundiária em termos de um certo número de sistemas de produção específica criou as condições para a emergência apenas localizada de um setor de pequena produção agrícola voltado para o mercado. Neste último caso, contudo, demonstramos o papel estrutural do trabalho assalariado no interior destas unidades de pequena produção, com base em resultados de pesquisas específicas e em dados globais secundários.

Assim, a primeira parte de nosso trabalho aborda três pontos básicos. Começa com um exame crítico da concepção dominante que determina a estratégia corrente de modernização do pequeno produtor. Em seguida, estabelece a correspondência entre esta concepção e as teorias acadêmicas no contexto brasileiro, fortemente influenciadas pelas polarizações falsas do debate clássico. Por último, com base numa análise global do objeto privilegiado desta estratégia modernizadora - o setor de pequena produção agrícola no Nordeste brasileiro - identificamos a falácia subjacente tanto à concepção de um setor essencialmente de pequena produção, quanto à suposta base familiar e autossuficiente do processo de trabalho desse setor.

$\mathrm{Na}$ segunda parte de nosso estudo, escolhemos três exemplos estruturalmente diferenciados de implementação desta política, a fim de identificar os elementos-chave comuns da dinâmica modernizadora e os fatores internos que ameaçam a consolidação de tal modernização.

Os componentes desta dinâmica são cumulativamente analisados nos três exemplos que estudamos. Aqui, aludiremos somente às conclusões mais essenciais que extraímos destes estudos, antes de considerar a questão teórica mais geral do status da exploração agrícola familiar modernizada para cuja apreciação os diferentes estudos de caso fornecem uma série de indicações básicas.
A essência da estratégia modernizadora é a integração do minifúndio ao circuito do crédito oficial, condicionando-se esta integração à adoção dos "pacotes" tecnológicos promovidos pelas equipes de assistência técnica dos serviços de extensão rural.

A tendência imediata produzida por esta integração é a transformação do minifundiário num produtor de mercadorias em tempo integral, dependente da produção de sua unidade agrícola para a manutenção de sua família.

Contudo, o aumento na produção resultante deriva principalmente de um dispêndio maior de trabalho, e não de aumento de produtividade por quantidade de trabalho despendido. Mesmo quando se observou um aumento de produtividade, isto não excluiu a tendência dominante de aumento absoluto na área cultivada.

Assim, a modernização - embora perseguida como uma alternativa à reforma agrária - foi incapaz de compensar a escassez de terra no minifúndio pelo aumento de produtividade por unidade de área. Então, a grande maioria do setor minifundiário não consegue consolidar esta transformação inicial e assumir plenamente o status de farmer (ver os dados referentes à região de Paraguaçu, no Capítulo Quatro), na medida em que não tem condições de suprir as necessidades de sua família com a produção de seu estabelecimento. Com isso, o processo de modernização fica bloqueado.

Mesmo se a política de modernização fosse generalizada ao conjunto do setor minifundiário, a maioria dos pequenos produtores seria incapaz de corresponder às suas precondições. Excluído dos efeitos da modernização, o minifundiário sofre um processo de marginalização que tenderá a expulsálo, num contexto de rápida valorização da terra acarretada pela pronta disponibilidade do crédito subsidiado e pelos programas especiais para a agricultura.

No caso das propriedades que têm condições de efetuar esta transformação, a integração ao crédito orientado cria uma nova dinâmica para a reprodução do pequeno produtor.

O pressuposto desta integração é o estabelecimento de uma nova base técnica para o processo de trabalho. $\mathrm{O}$ crédito tanto facilita quanto exige a incorporação de meios de produção adquiridos sementes selecionadas, 
fertilizantes, defensivos - que, por sua vez, geram uma dependência adicional de equipamentos agrícolas adquiridos e investimentos voltados a transformar a propriedade numa unidade produtiva viável (cercas, armazéns, meios de transportes). Então, cria-se uma dinâmica de tecnificação independente da acumulação no estabelecimento agrícola - e, pelo que observamos, geralmente na ausência desta.

Uma combinação de custos monetários de produção aumentados (e exacerbados pelos termos de troca desfavoráveis à produção agrícola) mais dependência exclusiva da renda obtida no estabelecimento gera metas de produção que exigem um montante de força de trabalho crescentemente superior ao disponível na unidade familiar. O crédito oficial facilita a incorporação estrutural de trabalho assalariado não-familiar, mas este não chega a substituir o trabalho familiar, e seu emprego é até concomitante com uma intensificação deste último excluindo-se assim qualquer tendência para um processo de diferenciação social.

A expansão contínua da área cultivada na base de um trabalho puramente manual, por sua vez, leva a um processo de declínio na produtividade, como o exemplo da fase de plantio na região de Irecê demonstrou (cf. nossa discussão no Capítulo Seis). Além disso, a dependência de uma oferta instável de mão de obra temporária desqualificada, cujo preço por unidade excede o do trabalho familiar, estimula a adoção da mecanização, buscada como uma forma de se restabelecer o controle do trabalho familiar sobre o processo de produção.

No entanto, o valor da produção desses pequenos estabelecimentos é insuficiente para custear a aquisição das formas de tecnificação dominantes - tratores, plantadeiras mecânicas, e máquinas de beneficiamento. Uma tecnologia alternativa não pode resolver esta contradição, pois suas premissas não combinam com o macrocontexto socioeconômico no qual se insere o pequeno produtor, nem em particular com as condições do crédito oficial, que estimulam um processo de tecnificação homogênea definida pela produção do setor agroindustrial.

Assim, o pequeno produtor em processo de modernização só consegue diminuir sua dependência do trabalho extrafamiliar ao custo da dependência de equipamentos agrícolas alugados. As particularidades do ciclo de produção (sincronização das várias operações, prazo em que certas fases têm que ser executadas) não permitem uma mecanização generalizada do processo de produção com base em arranjos de aluguel.

Com isso, a modernização fica bloqueada, produzindo-se um sistema híbrido de produção semimecanizada. Isto ameaça os índices de produtividade, e aumenta a vulnerabilidade deste setor às pressões de um setor agrícola de média e grande escala, totalmente mecanizado.

Assim, a estrutura agrária mais uma vez representa uma barreira estrutural à completa modernização do pequeno produtor, no contexto do Nordeste brasileiro. ${ }^{2}$

Além disso, observou-se que a política de modernização não contribuiu de forma alguma para "fixar o trabalhador no campo". ${ }^{3}$ Numa primeira instância, as facilidades de crédito não transformaram a base tradicionalmente não-remunerada do trabalho familiar. Ao invés disto, consolidaram uma dependência de trabalho temporário não-familiar como alternativa preferencial ao pagamento de um salário permanente para o jovem trabalhador adulto.

De forma semelhante, a mecanização, na medida em que ocorre, não só substitui o trabalho assalariado temporário, como também individualiza processos de trabalhos que antes eram coletivos, solapando assim a própria lógica do trabalho familiar, e contribuindo mais ainda para o êxodo rural.

No caso do Nordeste, portanto, a estrutura agrária historicamente constituída, e a persistência de uma política agrária que favorece a concentração de terra, são fatores que obstam uma modernização orgânica do setor da pequena produção.

Naturalmente, isto não quer dizer que o setor agrícola das grandes e médias propriedades deva ser definido como capitalista. Como vimos no capítulo sobre Irecê, na grande parte dos estabelecimentos médios, os proprietários eram produtores diretos (owner operators). ${ }^{4} \mathrm{O}$ que se verifica é que o processo de modernização implica economias de escala que

${ }^{2}$ Economias de escala crescentes, contudo, tornariam a modernização do pequeno produtor necessariamente seletiva, independentemente da estrutura agrária ou da política do governo. ${ }^{3}$ Slogan invariável de todos os discursos governamentais sobre a política agrária.

${ }^{4}$ A distinção inglesa entre family farm e owner operator capta perfeitamente a dissolução do processo de trabalho em consequência da modernização, ressaltando ao mesmo tempo o elemento de continuidade essencial - o proprietário como produtor direto. 
redefinem continuamente a área mínima para propriedades viáveis, e que esta área, como o exemplo de Irecê indica, ultrapassa os limites do setor da pequena produção tradicional do Nordeste.

Além disso, os níveis de valorização da terra impedem uma adaptação a esta economia de escala por meio da compra de terra.

\section{A modernização e os novos termos do debate}

Estudos recentes sobre a "agricultura familiar", tanto nos EUA, quanto na França, enfatizaram a elevação do tamanho mínimo da unidade de produção familiar como um efeito da tecnificação. No Relatório do Secretário da Agricultura do Congresso Americano, intitulado Status of the Family Farm, ${ }^{5}$ observa-se que o estabelecimento agrícola familiar médio aumentou de 278 acres (111 hectares) para 401 acres (160 ha), entre 1960 e 1978. Analogamente, André Mollard escreve o seguinte sobre o caso francês ${ }^{6}$ :

A análise do tamanho segundo os grupos de áreas mostra que as menores propriedades são as primeiras a desaparecer, enquanto que as médias conseguem manter-se provisoriamente - de 5 a 10 ha, até 1929; de 10 a 20 até 1955; e de 20 a 50 até o presente.

E, numa nota de rodapé acrescenta:

De acordo com as projeções até 1985 (...) o grupo de 20 a 35 ha, vai declinar a partir de 1970; o grupo de 35 a 50, a partir de 1975; e o estrato de 50 a 75 ha vai começar a desaparecer em 1985. A tendência geral, portanto, está bem estabelecida.

Esta concepção lança nova luz sobre o debate relativo ao papel da agricultura familiar, na medida em que tanto a modernização quanto a eliminação das unidades produtivas incapazes de atingir o limite mínimo constantemente redefinido são vistas como expressões da mesma tendência. Temos portanto um duplo processo de extinção e adaptação da agricultura familiar, solapando os argumentos que empregam dados sobre $\mathrm{o}$ 5 Status of the Family Farm. Segundo relatório anual ao Congresso. Departamento de
Agricultura dos EUA, Washington 1919 .

${ }^{6}$ André Mollard, p. 91 e 105. desaparecimento da pequena produção familiar como uma evidência do avanço da agricultura capitalista.

Além disso, na medida em que a modernização tornou-se a condição da sobrevivência da agricultura familiar, os termos do debate relativo à competividade desta última frente à agricultura capitalista também foram redefinidos.

Nos debates tradicionais (cf. nossa discussão sobre Kautsky e Chayanov no Capítulo Dois), e na forma como a tese dualista foi contestada no caso brasileiro, dizia-se que a superexploração e o subconsumo da unidade de trabalho familiar levavam a uma estrutura de preços para produtos agrícolas no mercado interno que minava a competividade capitalistas. $^{8}$

Contudo, a subordinação de toda a produção rural à valorização dos capitais agroindustriais - um processo estimulado tanto pela política estatal nacional quanto pela internacional - com sua tendência concomitante de aumento na produtividade por unidade de trabalho despendida anulam progressivamente as vantagens deriváveis de uma disposição em investir quantidades desproporcionais de trabalho absoluto.

Embora a tentativa de analisar esta nova realidade do "proprietário produtor direto" modernizado tenha produzido uma vasta literatura, pode-se identificar um número limitado de posições básicas.

\section{A tese da "modernização-capitalismo"}

Vários autores, recusando-se a considerar a especificidade do processo de trabalho do "proprietário produtor direto", identificaram como capitalistas todas as grandes propriedades (quer definidas em termos de capital fixo, quer

\footnotetext{
${ }^{7}$ Cf. "Le Développemennt du Capitalisme et la décomposition de la pay sannerie", Jean Cavailhes/Henri Ossard, Critique de l'Economie Politique, $n^{\circ}$ 23, 1976.

${ }^{8}$ A Crítica à razão dualista, de Francisco Oliveira, é o ponto de referência para este debate. Ela tem também sua formulação conservadora na tese de Rui Miller Paiva sobre o mecanismo de "autocontrole" inibindo a modernização generalizada. Cf. Setor agrícola no Brasil, SP, 1976
} 
em termos de área da propriedade), privilegiando as condições técnicas de produção ao invés da discriminação das relações de produção. ${ }^{9}$

Uma abordagem mais sofisticada é adotada por Dickinson e Mann, em seu artigo "Obstacles to the Development of a Capitalist Agriculture". Embora enfatizem predominantemente as características do processo de produção que tomam a agricultura avessa à apropriação capitalista (a predominância do tempo de produção sobre o tempo de trabalho, a rotatividade lenta do capital), estes autores sustentam que se o trabalho produtivo e improdutivo fossem discriminados, dentro do processo de trabalho agrícola, possivelmente o trabalho assalariado desempenharia um papel preponderante na geração do excedente. Esta posição, portanto, abre caminho para uma redefinição da agricultura baseada em trabalho essencialmente familiar como capitalista.

Contudo, nosso tratamento da relação entre o trabalho familiar e o assalariado, especialmente no Capítulo Cinco, enfatizando a inserção subordinada do trabalho assalariado na unidade de produção familiar e a lógica que impulsiona sua substituição, fornece uma crítica efetiva da interpretação puramente técnica realizada por Mann e Dickinson. ${ }^{10}$

\section{A tese da articulação em novo estilo e suas limitações}

A tendência dominante, contudo, tem sido a de se insistir no caráter não-capitalista da agricultura familiar modernizada, identificando-se as condições de sua competividade não mais em termos de superexploração e subconsumo, mas de sua capacidade de dispensar tanto a renda quanto o lucro.

O defensor clássico desta posição é Vergopoulos, cuja tese central é de que a agricultura familiar é a norma no contexto da expansão capitalista, na medida em que cria as condições para a eliminação da renda da terra e do lucro, permitindo assim,

\footnotetext{
${ }^{9}$ Ver Teoria econômica marxista, de Ernest Mandel, capítulo 9. No contexto brasileiro, ver também Paulo Sandroni, Questão agrária e campesinato, Ed. Polis, 1980.

${ }^{10}$ Cf. Journal of Peasant Studies, vol. 5, $\mathrm{n}^{\circ}$ 4, julho de 1978. Uma critica muito boa desta posição surgiu no artigo de Perelman (Cf. "Notes and Memoranda", Journal of Peasant Studies, vol. $\left.7, \mathrm{n}^{\circ} 1,1979\right)$ onde ele mostra que tais condições específicas seriam compensadas por uma taxa de lucro mais elevada, e que o real obstáculo à agricultura capitalista é a preexistência da agricultura camponesa, que não requer tal lucro.
}

(...) a máxima redução dos preços dos gêneros alimentícios e, consequentemente, do custo social de reprodução do processo de trabalho como um todo. ${ }^{11}$

Contudo, esta funcionalidade da agricultura familiar para a acumulação urbana de capital difere do modelo tradicional do subconsumo/superexploração, pois agora a agricultura familiar é vista como capaz de aumentar sua produtividade continuamente sem depender de acumulação derivada dos preços dos produtos agrícolas.

$\mathrm{Na}$ verdade, Vergopoulos sustenta que o impulso para o aumento na produtividade é uma resposta exatamente à necessidade de compensar a queda nos preços por unidade de produto, por meio de aumentos na massa total de produção. A produção familiar portanto reage a preços desfavoráveis com aumentos na produtividade em condições que expulsariam agricultores capitalistas do mercado.

A posição de Vergopoulos parece um tanto problemática em relação ao caso específico da Grécia. ${ }^{12}$ Além disso, seus argumentos são às vezes contraditórios, particularmente quando ele sustenta que sua análise:

é mais relevante para aqueles setores da produção onde a proporção do trabalho aplicado é maior e mais difícil de ser substituída por máquinas, ou seja, nos setores trabalho-intensivos da agricultura. ${ }^{13}$

E, no caso da agricultura mecanizada, ele admite:

que a influência de custos de trabalho baixos na escolha entre uma ou outra forma de produção (no caso, a escolha entre a forma de produção capitalista ou familiar) é minimizada. ${ }^{14}$

Nesta segunda formulação, a superioridade da agricultura familiar seria reduzida àquelas seções da agricultura onde a tecnificação não leva a uma redução absoluta na quantidade de trabalho necessária ao processo produtivo (e a diminuir o peso da baixa remuneração do trabalho).

11 Ver "Capitalism and Peasant Productivity", JPS, vol. 5, $\mathrm{n}^{\circ}$ 4, 1978, e também "Capitalismo disforme (o caso da agricultura no capitalismo)", em A questão camponesa e o capitalismo, S. Amin/Vergopoulos, Ed. A Regra do Jogo, 1978

${ }_{12}$ Ver Nicos Mouzelis, "Peasant Agriculture, Productivity, and the Laws of Capitalist Development: A Reply to Vergopoulos", JPS, vol. 6, n 3, 1979.

${ }^{13}$ Ver "Capitalism and Peasant Productivity", op. cit., p. 456.

${ }^{14}$ Op. cit., p. 456. 
Este modelo de especialização tem sua elaboração mais sistemática na obra de Servolin. ${ }^{15}$ Além do argumento de baixa remuneração do trabalho, este autor enfatiza que a persistência da determinação biológica sobre o processo de trabalho requer uma supervisão especial, para a qual o trabalho assalariado seria menos apropriado que o do "proprietário produtor direto" (owner operator) e sua família.

No contexto de nosso estudo, é importante assinalar que os produtos tradicionais do setor da pequena produção são eminentemente mecanizáveis - milho e feijão. Se o modelo da especialização fosse válido, no Nordeste ele implicaria uma sobrevivência preferencial não do pequeno produtor tradicional mas dos bolsões isolados de agricultura irrigada de pequena escala que atualmente são também objetos das políticas modernizadoras estatais. ${ }^{16}$

Contudo, nos termos da posição de Vergopoulos, a superioridade da agricultura familiar não se reduz necessariamente à baixa remuneração. Como vimos no exemplo de Irecê, a divisão da renda líquida pelos membros da família permitiria uma remuneração correspondente ao salário mínimo. ${ }^{17}$ Mesmo se a remuneração salarial fosse equalizada entre os setores da agricultura capitalista e familiar, e mesmo se os investimentos em capital constante reduzissem a importância relativa deste salário, a lógica da reprodução simples explicaria a competividade da agricultura familiar frente a empresas orientadas para a obtenção de lucro.

Em particular, a relação entre preços desfavoráveis e incremento na produtividade corresponde à dinâmica que analisamos tanto no exemplo do PEC/SR quanto no de Irecê. A absorção de insumos modernos, a mecanização e a expansão da área cultivada não refletem então um processo de reprodução ampliada, mas sim uma resposta à constante elevação do

${ }^{15}$ L'absorption de l'agriculture dans le mode de production capitaliste", em L'univers politique des paysans, Paris, 1972.

${ }_{16}$ Antes, a política estatal de irrigação estava limitada a projetos de colonização, cuja execução estava sob a responsabilidade de dois órgãos - o DNOCS e a CODEVASF. O primeiro, baseando-se em produtores familiares, estagnou nos últimos anos (Cf. a crítica de Anthony Hall, em "Drought and Irrigation in Northeast Brasil"); já a CODEVASF, mais dinâmica, tendeu a substituir a produção familiar por firmas de média e grande escala. Cf. Sorj, B., Estado e classes sociais na agricultura brasileira, op. cit., p. 95.

${ }^{17}$ Ver Capítulo Seis. limite mínimo para a reprodução simples que permite a manutenção do produtor direto e sua família. ${ }^{18}$

Contudo, este achado crucial permanece carente de elaboração teórica na análise de Vergopoulos, que se limita à tradicional problemática setorial e funcional da defesa da agricultura familiar como o mecanismo mais eficiente para a transferência do excedente que subsidia a acumulação industrial:

O centro de minha análise é a questão da superioridade da agricultura familiar em relação à empresa agrícola capitalista - uma superioridade que deve ser entendida sob o ponto de vista do processo de acumulação urbana de capital. ${ }^{19}$

\section{A tese do complexo agroindustrial}

Neste sentido, a posição de Vergopoulos fica num estágio de transição para o que pode ser descrito como a "tese do complexo agroindustrial". Esta última desloca a argumentação de uma consideração setorial da superioridade da agricultura capitalista versus a da agricultura familiar não-capitalista (com o debate subsidiário sobre o grau em que esta pode na verdade ser considerada uma empresa capitalista), para uma análise da agricultura familiar como a forma sob a qual a relação capital/trabalho se expressa na agricultura.

Estas análises se caracterizam, em diferentes graus, por uma tentativa de elaborar teoricamente o achado empírico central à obra de Vergopoulos - a transformação dos processos técnicos no interior da agricultura familiar.

Marx já havia enfatizado que a base tradicional da competitividade camponesa era a sua capacidade de ultrapassar tanto o limite de renda quanto o do lucro, ${ }^{20}$ mas havia negado que a pequena produção tivesse capacidade de revolucionar sua base técnica:

\footnotetext{
${ }^{18}$ Ver Brandão Lopes, "Tecnificação dos pequenos produtores em São Paulo", mencionado no Capítulo Seis.

${ }^{19}$ Capitalism and Peasant Productivity", op. cit., p. 456. Como corolário desta posição, a reforma agrária é defendida como um meio de permitir esta transferência do excedente, e não pela necessidade primária de se expandir o mercado interno para produtos industriais. ${ }^{20}$ Marx, O capital, vol. III, p. 804.
} 
Por natureza, a propriedade parcelária exclui o desenvolvimento da produtividade social do trabalho, as formas sociais de trabalho, a concentração social dos capitais, a pecuária em grande escala, e a aplicação progressiva da ciência. ${ }^{21}$

O sucesso da agroindústria em libertar a agricultura familiar de suas restrições produtivas, contradizendo a análise de Marx, levou a tentativa de se redefinir a natureza de relação capital/trabalho, de modo a incluir o fenômeno do produtor direto com direitos jurídicos sobre seus meios de produção - no caso, a terra.

Esta redefinição ocorre em graus de rigor variáveis. Num influente estudo de Faure, ${ }^{22}$ é feita uma tentativa de apartar-se o conceito de subsunção formal ao contexto da agricultura familiar cujo processo de produção tenha sido redefinido pela incorporação ao circuito agroindustrial. Neste sentido, o termo "formal" serve para indicar a permanência da propriedade do meio de produção básico - a terra - nas mãos do produtor direto.

No entanto, esta caracterização é particularmente imprópria, por duas razões. Tanto a subsunção formal quanto a real se referem, em Marx, a condições em que o produtor direto já foi separado de seus meios de produção. ${ }^{23} \mathrm{E}$, o que é ainda mais importante, a subsunção formal refere-se especificamente à fase em que o capital expropriou mas não revolucionou a base produtiva. Portanto, o conceito é bastante inadequado para caracterizar as particularidades do processo de trabalho da agricultura familiar, onde a transformação do processo produtivo ocorreu, e no entanto a propriedade jurídica dos meios de produção permanece em mãos do produtor. ${ }^{24}$

Uma abordagem mais comum tem levado à distinção entre propriedade jurídica e propriedade efetiva dos meios de produção, redefinindo o conceito de "trabalhador livre" de modo a incluir produtores

\footnotetext{
${ }^{21}$ Op. cit., vol. III, p. 807.

${ }^{22}$ Ver Claude Faure, Les paysans dans la production capitaliste, Paris, 1978 (mimeo).

${ }^{23}$ Marx, O Capital, vol. I: "Results of the Imediate Process of Production", p. 1.010-1.039.

${ }^{24} \mathrm{Em}$ La production paysanne et l'erploitation capitaliste (mimeo), Faure reconhece a heterodoxia de sua aplicação destes conceitos, mas mantém o seu emprego.
}

que, embora juridicamente possuidores de terra, não têm condições de exercer um controle real sobre o processo de trabalho. ${ }^{25}$

Estes autores, cuja preocupação se dirige mais ao nível da reprodução global, têm argumentado que, embora a apropriação do excedente aparentemente ocorra na esfera da circulação, através do mecanismo de preços, esta é apenas a forma particular sob a qual a exploração se expressa no caso da agricultura familiar subordinada ao capital agroindustrial.

Tal ponto de vista é timidamente esboçado por Bernstein

Embora o mecanismo de apropriação do trabalho excedente camponês tome a forma de uma troca, nossa tese sugere que a apropriação tem que localizar-se primeiro na produção. Isso levanta a questão da produção da mais-valia, ainda que em condições menos determinadas que as da produção capitalista. ${ }^{26}$

\section{E, mais enfaticamente, também por Mollard:}

As relações de troca entre os produtores e agroindústria são cada vez menos capazes de ocultar a consolidação das relações de produção capitalistas entre trabalhadores e não-trabalhadores. ${ }^{27}$

Embora desenvolvida no contexto dos debates sobre a transição e articulação dos modos de produção, a posição de Banaji pode ser considerada como oferecendo uma justificativa teórica geral da tese específica do complexo agroindustrial. ${ }^{28}$ Para Banaji, "o trabalho assalariado, trabalho que produz capital, pode assumir uma série de formas não-livres". Ele elabora sua posição distinguindo "as formas de exploração imediatas do trabalho vivo" das "relações de produção subjacentes, das quais são uma expressão historicamente dada".

O problema desta posição, contudo, é que ela deixa de considerar o impulso do capitalismo em direção a uma produtividade sempre crescente deste trabalho vivo, o que implica limites para as "formas de exploração

\footnotetext{
${ }^{25}$ Para o caso brasileiro, cf. Wanderley e Graziano da Silva, Op. cit. acima, cap. I. A obra de Mollard, citada acima, representa a elaboração mais sistemática desta perspectiva.

${ }^{26}$ H. Bernstein, "Notes on Capital \& Peasantry", Review of African Political Economy, no 10, 1977, p. 72.

27 A. Mollard, op. cit., p. 195

${ }^{28}$ J. Banaji, "Gunder Frank in Retreat", JPS, 1981; Cf. também "Modes of Production in a Materialist Conception of History", Capital and Class Autumn, 1977.
} 
imediatas" possíveis. Mesmo assim, a distinção feita por Banaji realmente oferece uma justificativa teórica para a definição da relação entre agricultura familiar e agroindústria como uma relação capitalista.

Embora a relação capital/trabalho seja definida como capitalista por estes autores, reconhece-se que sua especificidade formal tem importantes repercussões político-sociais, levando a diferentes padrões de luta de classes em função da terra, dos preços e do crédito sendo que estes dois últimos tendem a deslocar a primeira como base para a mobilização. ${ }^{29}$

A tese agroindustrial, portanto, sustenta essencialmente que, embora a forma da relação capital/trabalho seja específica, gerando importantes efeitos ao nível sociopolítico, o processo de trabalho deve ser definido como realmente subordinado ao capital.

\section{Subordinação real e conclusões extraídas dos trabalhos de campo}

A concepção acima se adapta bem a vários dos elementos analisados em nossos estudos de caso. Em primeira instância, o endividamento mais a pressão da valorização da terra tendem a fechar o caminho para um retomo à agricultura de subsistência tradicional. Além disso, embora o controle sobre o processo de trabalho esteja menos consolidado, em função do insuficiente desenvolvimento do capital agroindustrial na região (falta de sementes, rede de distribuição ineficiente para os insumos), vimos como a relação direta do produtor com sua terra tinha sido rompida. A forma de acesso do produtor à sua terra está determinada agora pelas condições impostas pelo crédito oficial e pela assistência técnica, principais mediadores do capital agroindustrial no Nordeste brasileiro. Assim, o controle efetivo da terra depende mais da eficácia dos insumos agroindustriais que dos direitos legais do proprietário direto.

Ao mesmo tempo, vemos como o mecanismo de crédito substitui a acumulação no estabelecimento agrícola como precondição para a

${ }^{29}$ Para Bemstein, a forma assumida pela luta de classes deriva do fato de que os produtores diretos não estão totalmente expropriados, e desenvolvem "uma luta pela posse e controle efetivos" (Op. cit., p. 73), o que poderia sugerir que, para o capital, o status camponês seria transitório. Por outro lado, Mollard tem uma visão mais funcional, enfatizando tanto os benefícios econômicos (menor dispêndio de capital) quanto políticos (separação ideológica entre farmers e trabalhadores industriais) da conservação da propriedade formal em mãos dos farmers. tecnificação por um subsídio social, tornando aquela acumulação compatível com a reprodução simples do produtor direto.

\section{Crítica dos conceitos de subordinação real e de complexo agroindustrial}

No entanto, o conceito de subordinação real do processo de trabalho familiar não foge a uma tendência funcionalista. Concentrando-se na capacidade do capital para revolucionar o processo de trabalho em condições em que a propriedade jurídica da terra continua com o produtor direto, tal enfoque tende a obscurecer as contradições internas da agricultura familiar. É digna de nota a falta de qualquer tratamento específico da questão relativa ao suprimento de trabalho no contexto de uma produtividade crescente. Na prática, como vimos no Capítulo Um de nosso estudo, a tese agroindustrial adota a tradicional visão do excedente de trabalho na agricultura familiar.

A capacidade do capital para revolucionar continuamente o processo de produção depende da constante redefinição da natureza e das dimensões dos meios de produção. No caso da exploração familiar, contudo, tanto a terra quanto o trabalho são quantidades relativamente fixas.

Em nossos estudos de caso, mostramos como, ao nível do processo de trabalho, a subordinação ao capital agroindustrial demandou inicialmente a incorporação estrutural do trabalho não-familiar, e, ao aprofundar-se, tendeu a uma substituição não só do trabalho assalariado como também do próprio trabalho familiar.

Portanto, nos casos que estudamos, a agroindústria tendeu a dissolver a família como unidade de produção. Uma vez que isto tenha ocorrido, a pressão para o êxodo rural da família como um todo especialmente devido às restritas oportunidades de emprego no campo - torna-se particularmente poderosa, ameaçando a viabilidade da exploração agrícola baseada no "proprietário produtor direto" (owner operador).

Como vimos, também o tamanho mínimo da terra tende a ser constantemente redefinido sob a pressão da agroindústria, levando à imposição sucessiva de novas economias de escala não necessariamente compatíveis com a unidade de trabalho familiar. Mesmo nos limites da versão da tese agroindustrial em termos de especialização, certas áreas da 
produção (por exemplo, a avicultura) atingiram graus de concentração e de simplificação de tarefas que excedem o suprimento de trabalho na exploração familiar e restabelecem a eficácia do trabalho assalariado simples.

A relativa fixidez do trabalho e da terra na agricultura familiar, em contraste com a tendência capitalista para uma constante redefinição dos meios de produção apropriados, deveria então sugerir reservas quanto à subordinação real do trabalho familiar na agricultura.

Porém, embora a tese agroindustrial forneça um referencial teórico útil para a análise de certos aspectos do processo de modernização, ela é severamente limitada como um modelo geral para a apropriação capitalista da agricultura.

Deixando de lado sua incapacidade de explicar a poderosa presença de uma agricultura classicamente capitalista, exceto em termos de um modelo de especialização excessivamente funcionalista cujas limitações já indicamos acima, a tese peca por uma falta de atenção às características específicas da terra como meio de produção e não simplesmente como expressão de uma relação social, e também pela falsa abstração de um "complexo agroindustrial”" como expressão homogênea do capital.

Em nossos estudos de caso, os persistentes fracassos das colheitas e a falta de uma correspondência entre a absorção de insumos moderno e aumentos em produtividade atestam a predominância continuada de fatores naturais no processo de trabalho. Assim, o capital pode muito bem conseguir superar a barreira da terra como relação social, mas continuará a confrontar-se com um processo de produção essencialmente natural. Identificar o problema do acesso à terra como central para a subordinação capitalista real do processo de trabalho agrícola é deixar de considerar este caráter fundamentalmente natural do processo de produção. Assim, no contexto da dinâmica do capital em direção à apropriação de todo processo de produção valorizável, a terra como elemento natural, mais do que a terra como expressão de uma relação social, continua a ser a barreira fundamental à subordinação real do processo de trabalho agrícola.

E, por fim, o conceito de "complexo agroindustrial” é profundamente enganoso na medida em que implica uma forma unificada de capital. Uma vez adotada esta posição, a ideia da agroindústria e da agricultura familiar reproduzindo a relação capital/trabalho torna-se prontamente aceitável.

No entanto, historicamente e em suas condições de expansão, diferentes ramos da agroindústria têm relações autônomas e até conflitantes com o processo de trabalho agrícola direto. Mais, em vez de combinar-se para efetuar uma subordinação unificada, cada qual procura antes de tudo expandir o mercado para seus próprios produtos no setor agrícola, independentemente da racionalidade da absorção destes produtos em termos do próprio processo de trabalho.

Em vez de a exploração assumir a forma de uma relação de troca, temos um processo de consumo forçado de produtos agroindustriais que toma a forma de uma crescente subordinação do processo de trabalho agrícola ao capital.

Esta procura de mercados em permanente expansão para os produtos agroindustriais tem levado a uma supercapitalização crônica da agricultura familiar. $^{30}$ Além disto, os adubos e defensivos são adotados independentemente de seus efeitos em termos de produtividade. ${ }^{31}$

$\mathrm{O}$ endividamento do pequeno produtor, que observamos como traço estrutural no caso dos programas de modernização, e que é uma característica geral da agricultura familiar modernizada, é um reflexo do caráter cada vez mais ineficiente do processo de trabalho, analisado ao nível da unidade de exploração agrícola. Mais que a subordinação real, a anarquia de um processo de trabalho transformado numa arena para a realização de capitais agroindustriais conflitantes é o produto da incorporação ao circuito do "complexo agroindustrial". ${ }^{32} \mathrm{E}$ finalmente, o indicador mais crucial da peculiaridade do processo de trabalho agrícola é a destruição progressiva do

\footnotetext{
${ }^{30} \mathrm{Cf}$. Mollard, Op. cit.

${ }^{31} \mathrm{Na}$ região de Irecê, os recursos do crédito estão condicionados ao emprego de fertilizantes, embora a fertilidade natural do solo torne seu uso redundante. No caso da produção de soja as aplicações de defensivos recomendadas no Brasil eram dez vezes maiores que as usadas nos EUA.

32 No contexto de nossos estudos de caso, o fracasso de "tecnologia alternativa", especificamente planejada para harmonizar os diferentes elementos do processo de trabalho no contexto da modernização, é uma eloquente demonstração da incoerência da lógica imposta ao processo de trabalho pela subordinação à agroindústria, quando esta é encarada do ponto de vista das unidades produtoras agrícolas.
} 
meio de produção básico, a terra, pela erosão - resultado direto da subordinação aos insumos agroindustriais. Assim, a agroindústria, mais que implicar uma subordinação real do processo de trabalho agrícola, parece permitir a conservação da propriedade da terra em mãos do produtor direto por recusar-se a assumir a responsabilidade por um processo de trabalho ainda dominado pelas forças naturais.

Uma discussão destas questões, no entanto, levar-nos-ia para além dos limites deste estudo, devendo ser deixada para uma próxima ocasião. ${ }^{33}$

\footnotetext{
33 From Farming to Biotechnology. The industrial Appropriation of Agriculture, D.
} Goodman, B. Sorj e John Wilkinson (em preparo).

\section{Bibliografia}

AMIN, S. e VERGOPOULOS, K. (1978) A questão camponesa e o capitalismo. A Regra do Jogo.

AMORIM, P. (1980) Crédito rural e pequena produção em Tucano. Univ. Fed. da Bahia. Mimeo.

ANDRADE, M. C. (1973) A terra e o homem no Nordeste. Brasiliense, São Paulo.

ANDRADE, R. de C. (s. d.) The Economics of Underdevelopment. The State and Politics in ECLA's Doctrine. Mimeo.

ARCHETTI, P. (1976) "La comuna campesina en Rusia", in Chayanov, A. V. La organización de la unidad económica campesina. Buenos Aires.

ARROYO, G. (1977) Institutional Constraints to Policies for Achieving Increased Food Production in Selected Countries. Groupe de Recherches Sociologiques, Université de Paris.

BANAJI, J. (1977) "Modes of Production in a Materialist Conception of History", Capital and Class, Autumn.

(1981) “Gunder Frank in Retreat”. Journal of Peasant Studies.

BANCO DO BRASIL (1980) Projeto de Crédito Rural do POLONORDESTE. Brasília.

BANDEIRA, M. (1975) Cartéis e desnacionalização. Civilização Brasileira. Rio de Janeiro.

BARTRA, R. (s. d.) La teoría del valor y la economía campesina: invitación a la lectura de Chayanov. Mimeo.

BERNSTEIN, H. (1977) "Capital and Peasantry", Review of African Political Economy, 10

CALDEIRA, C. (1954) Fazendas de cacau. São Paulo. Mutirão: formas de ajuda mútua no meio rural. São Paulo.

CAMARA, A. da S. e FONTES, S. S. (1980) Pequenos produtores locais na bacia do Paraguaçu. Univ. Fed. da Bahia. Mimeo. 
CARDOSO. F. H. (1975) Autoritarismo e democratização. Paz e Terra, Rio de Janeiro.

CASTRO, A. B. de (1969) 7 ensaios sobre a economia brasileira. Forense, Rio de Janeiro.

CASTRO, A. C. et al. (1979) Evolução recente e situação atual da agricultura brasileira. BINAGRI.

CAVAILHES, J. e OSSARD, H. (1976) "Le développement du capitalisme et la décomposition de la paysannerie", Critiques de l'économie politique, 23. Paris.

CEPA-Ba (1977) Plano Plurianual: PDRI Paraguaçu. Salvador.

(1980) Fumo na Bahia. Diagnóstico preliminar. Salvador. (1981) Informe mensal de acompanhamento conjuntural. Bahia.

CEPLAB (1979) A penetração do café na Bahia. Bahia.

CHALOULT, Y. et al. (1980) A experiência em desenvolvimento rural integrado no Nordeste brasileiro. CEPA-Rio Grande do Norte.

(1980) Políticas do Estado e desenvolvimento rural integrado no Brasil. Mimeo.

CHAYANOV, A. V. (1976) La organización de la unidad económica campesina. Buenos Aires.

COELHO, J. (1974) Crédito rural no Nordeste $e$ os serviços complementares. Mimeo.

CORADINI, L. (1979) Estrutura agrária, classes sociais e cooperativismo no Sul do Brasil. Univ. Fed. de Minas Gerais. Mimeo.

CPE-Ba (1975) Vales úmidos da bacia de Paraguaçu. Salvador.

DIAS, G. M. (1978) Depois do latifúndio. Universidade de Brasília. (1978) The Brazilian Peasantry and the Development of Capitalism in the 20th Century. Nineth World Congress of Sociology, Upsala.

DICKINSON, J. e MANN, S. (1978) "Obstacles to the Development of a Capitalist Agriculture", Journal of Peasant Studies, 5, n’. 4.

DREVON, J. J. (1976) Développement rural et technologies alternatives dans la stratégie de la Banque Mondiale. Groupe d'Etude des Relations Economiques Internationales (GEREI). Paris.

DUQUE. G. (1980) Estratégia camponesa: ação de classe disfarçada. Encontro Realidade Nordestina. Campina Grande.

(1980) Casa Nova: intervention du pouvoir et stratégie paysanne. Ecole des Hautes Etudes en Sciences Sociales.

EMATERBA (1980) Análise da ação social junto ao trabalho de produção em Irecê. Bahia.

__ (1980) Levantamento da realidade agrícola da região de Irecê. Bahia.

FAURE, C. (1978) Agriculture et capitalisme. Anthopos.

(1979) La production paysanne et l'exploitation capitaliste. Mimeo.

FEDER, E. (1976) "The New World Bank Program for the Self-liquidation of the Third World Peasantry", Journal of Peasant Studies, 3, nº 3.

FIORENTINI, R. e REDWOOD III, J. (1980) Características e consequências do POLONORDESTE e análise preliminar das necessidades de capacitação dentro do programa. SUDENE-OEA, Recife.

(1980) Uma visão geral do funcionamento do Programa POLONORDESTE. Recife.

FORMAN, S. (1979) Camponeses: sua participação no Brasil. Paz e Terra.

GALVÃO, H. (1959) O mutirão no Nordeste. Rio de Janeiro.

GOODMAN, D. E. (1977) "Rural Structure, Surplus Mobilisation and Modes of Production in a Peripheral Region: the Brazilian Northeast", Journal of Peasant Studies, 5, nº1.

GOODMAN, D., SORJ, B. e WILKINSON, J. Farming and Capitalism: the Industrial Appropriation of Agriculture. No prelo.

GUIMARÃES, A. P. (1977) Quatro séculos de latifúndio. Rio de Janeiro, Paz e Terra.

HALL, A. (1978) Drought and Irrigation in Northeast Brazil.

HARRISON, M. "Chayanov and the Economics of the Russian Peasantry", 
Journal of Peasant Studies.

(1979) "Chayanov and the Marxists", Journal of Peasant Studies, 7, $\mathrm{n}^{\mathrm{o}} 1$.

"The Peasant Mode of Production in the Work of A. V. Chayanov", Journal of Peasant Studies.

HENFREY, C. (1981) "Dependency, Modes of Production and the Class Analysis of Latin America", Latin American Perspectives.

HEWETT DE ALCÂNTARA, C. (1978) La modernización de la agricultura mexicana, 1940-1970. Siglo Veinteuno.

IANNI. O. (1976) A classe operária vai ao campo. Cadernos CEBRAP 24. (1973) "Relações de produção e proletariado rural", in Szmrecsányi T. e Queda, O. Vida rural e mudança social. Nacional. São Paulo.

INCRA (s. d.) Os problemas fundiários na estratégia do desenvolvimento e de segurança. Ministério da Agricultura.

JANVRY. A. de e CROUCH, L. Technological Change and Peasants in Latin America. University of California.

KAUTSKY. K. (1970) La cuestión agraria. Ruedo Ibérico.

LEMOS. M. B. (1977) Um estudo comparativo sobre as formas de organização da produção de arroz no Brasil. Campinas. Mimeo.

LÊNIN, V. I. (1977) The Development of Capitalism in Russia. Moscou. (1980) O programa agrário. São Paulo.

LOPES, J. R. B. (1973) "Desenvolvimento e migrações", Estudos CEBRAP

(1978) "Empresas e pequenos produtores no desenvolvimento do capitalismo agrário em São Paulo", Estudos CEBRAP 22.

(1981) A tecnificação dos pequenos produtores em São Paulo. Mimeo.

LOUREIRO, M. R. G. (1977) Parceria e capitalismo. Zahar, Rio de Janeiro.

(1981) Cooperativas agrícolas e capitalismo no Brasil. Cortez, São
Paulo.

MANDEL, E. (1971) Marxist Economic Theory. The Merlin Press.

MORAES, C. (1970) "Peasant Leagues in Brazil", in Agrarian Problems and Peasant Movements in Latin America. Stavenhagen (ed.) Anchor Books.

MARCONDES, J. V. (1948) "Mutirão ou Mutual Aid", Rural Sociology.

MARTINS, J. de S. (1981) Os camponeses e a política no Brasil. Vozes, Petrópolis.

MARX, K. (1976) Capital, vol. I. Pelicano

_ (1977) Capital, vol. III. Lawrence and Wishart.

MALUF, R. S. T. (1977) A expansão do capitalismo no campo: o arroz no Maranhão. Unicamp, IFCH/DEPE. Mimeo.

MELLO. M. C., d'I. e (1976) O bóia fria: acumulação e miséria. Vozes, Petrópolis.

MELO. M. L. de (1978) Regionalização agrária do Nordeste. SUDENE, Recife.

MELO, M. T. S. de (1977) Cassacos e corumbas. São Paulo.

MENDES JR. A. et al. (1979) "Palmares, símbolo de liberdade". In Brasil História 1. Colônia. Brasiliense, São Paulo.

MINISTÉRIO DA AGRICULTURA (1977) Crédito rural, 1969-76, vol. IV. Região Nordeste. Brasília.

(1975-1977) Diretrizes gerais para o POLONORDESTE. Mimeo.

(1978) Relatório final do Grupo de Trabalho para a Promoção de Produtores de Baixa Renda. Mimeo.

(1980) Programa Nacional de Promoção de Pequenos Produtores Rurais. Brasília.

MOUZELIS, N. (1979) "Peasant Agriculture, Productivity and the Laws of Capitalist Development: a Reply to Vergopoulos", Journal of Peasant Studies, 6, nº 3.

MULLER, G. (1982) “Agricultura e industrialização do campo no Brasil”, 
Revista de economia política, 2/1, $\mathrm{n}^{\mathrm{o}} .6$.

MURRAY, R. (1978) "Value and Theory of Rent", Capital and Class. nº. 4.

NEVES, D. P. (1981) Lavradores e pequenos produtores de cana. Zahar, Rio de Janeiro.

OLIVEIRA, F. (1972) "Crítica à razão dualista", Estudos CEBRAP 2. (1977) Elegia para uma re(li)gião. Paz e Terra, Rio de Janeiro.

PAIVA, R. M. (1976) Setor agrícola do Brasil. São Paulo.

PATNAIK, U. (1979) "Neo-Populism and Marxism: the Chayanovian View of the Agrarian Question and its Fundamental Fallacy", Journal of Peasant Studies, 6, n'. 4.

PERELMAN, M. (1979) "Obstacles to the Development of a Capitalist Agriculture: a Comment on Mann and Dickinson", Journal of Peasant Studies, $7, \mathrm{n}^{\circ} .1$.

PINTO, L. C. (1980) Notas sobre a política de crédito rural. Campinas. Mimeo.

PONPERMAYER, M. (1979) The Frontier and the State in Brazil: a CaseStudy of the Amazon. Stanford.

PRADO JR., C. (1979) A questão agrária no Brasil. Brasiliense, São Paulo.

REIS, M. B. dos (1976): "Mão-de-obra e elementos de relações de produção", in Diagnóstico socioeconômico da região cacaueira. CEPLAC/IICA, Bahia.

RESENDE, P. G. C. (1978) "Produção, emprego e estrutura agrária na região cacaueira da Bahia", Planejamento econômico 8, Rio de Janeiro.

SÁ, F. (1973) "O desenvolvimento da agricultura nordestina e a função das atividades de subsistência", Estudos CEBRAP 3.

SALVADORI. M. (1979) Karl Kautsky and the Socialist Revolution 18801938. New Left Books.

SAMPAIO. Y. et al. (1978) Política agrícola no Nordeste. BINAGRI.
(1980) Desenvolvimento rural no Nordeste: a experiência do POLONORDESTE. PIMES.

SANDRONI, P. (1980) Questão agrária e campesinato. Polis.

SEPLANTEC (s./d.) Estudos sobre o abastecimento alimentar da região metropolitana de Salvador. Bahia.

SEPLANTEC-CPE (1981) Pesquisa sobre associativismo entre os pequenos produtores de Irecê. Bahia.

SERVOLIN, C. (1972) 'L'absorption de l'agriculture dans le mode de production capitaliste", in L'univers politique des paysans dans la France contemporaine. Paris.

SIGAUD, L. (1977) Os clandestinos e os direitos. São Paulo.

SILVA, F. G. da (org.) (1978) Estrutura agrária e produção de subsistência na agricultura brasileira. HUCITEC, São Paulo.

(1980) “A pequena produção e as transformações da agricultura brasileira". Cadernos do CEAS 69

(1980) Progresso técnico e relações de trabalho na agricultura paulista. Campinas. Mimeo.

SOLOMON, S. G. (1978) The Soviet Agrarian Debate. Boulder, Colorado.

SORJ, B. (1980) Estado e classes sociais na agricultura brasileira Zahar, Rio de Janeiro.

STRYKER, R. (1979) "The World Bank and Agricultural Development", World Development 7.

SUDENE (1978) Incentivos fiscais na Bahia. Recife.

TALLWORTH. K. (1979) Der Staudam von Sobradinho: Infrastrukturelle Erschliessing einer Region un Vereledung und Proletariesierung von Subsistenzbauern. Univ. Bielefeld.

TAVARES DOS SANTOS, J. V. (1978) Colonos do Vinho, HUCITEC, São Paulo.

UNIDADE TÉCNICA PDRI IRECÊ (1981) Histórico do PDRI Irecê. Bahia. 
UNIDADE TÉCNICA PDRI PARAGUAÇU (s. d.) Avaliação do segmento comercialização. Salvador. Mimeo.

_ (s./d.) Comercialização. Mimeo.

(s./d.) Cooperativismo. Mimeo.

(s./d.) Sub-Project for Technical Assistance and Rural Credito Salvador. Mimeo.

(1981) Pesquisa da unidade produtiva. Salvador. Mimeo.

(1981) Resumo do PDRI Paraguaçu. Salvador.

US SECRETARY OF AGRICULTURE. (1979) Status of the Family Farm: Second Annual Report to Congress. Washington.

VELHO, O. G. (1976) Capitalismo autoritário e campesinato. DIFEL, São Paulo.

__ (1977) “Campesinato e política”, Anuário antropológico.

(1981) Frentes de expansão e estrutura agrária. Zahar, Rio de Janeiro.

VERGOPOULOS, K. (1978) "Capitalism and Peasant Productivity", Journal of Peasant Studies $5, \mathrm{n}^{\circ} .4$.

WANDERLEY, M. de N. B. "Algumas reflexões sobre o campesinato do Nordeste: conceito e realidade", Ciência e Cultura 29, n .5.

__ (1980) O camponês: trabalhador para o capital. Mimeo.

WILKINSON, J. (1978) Uma avaliação de programas governamentais para agricultores de baixa renda. CEPA-Ba.

WORLD BANK (1973) Rural Development Issues and Options in Northeast Brazil. Washington.

(1973) Rural Development: a Document of Sectoral Policy. Washington.

(1975) Desarrollo rural: documento de política sectorial. Washington.

_ (1977) PDRI Paraguaçu. Relatório $n^{o} .5$ crédito rural. Unidade Técnica PDRI Paraguaçu, Bahia.
(1978) Mechanization Services and the Supply of Inputs. Document $n^{\circ}$ 7 PDRI Paraguaçu.

ZAMOSC, L. (1980) El fique y los empaques en Colombia. Bogotá, D.E. 